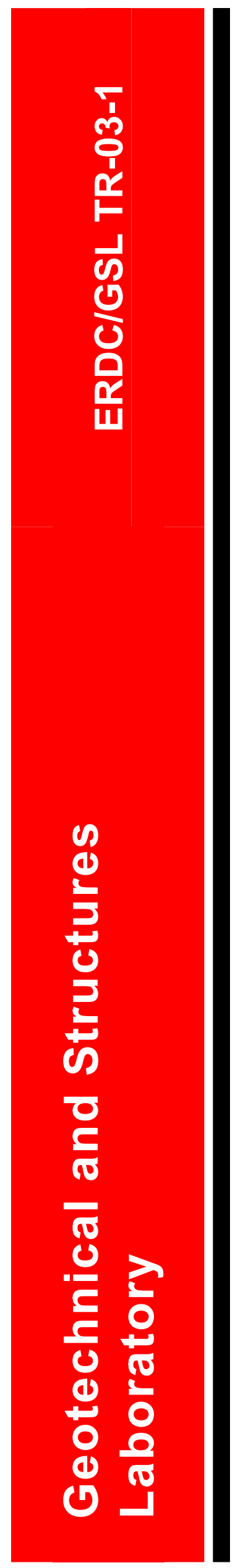

Rejuvenators, Rejuvenator/Sealers, and Seal Coats for Airfield Pavements

James E. Shoenberger

February 2003 
ERDC/GSL TR-03-1

February 2003

\title{
Rejuvenators, Rejuvenator/Sealers, and Seal Coats for Airfield Pavements
}

\author{
James E. Shoenberger \\ Geotechnical and Structures Laboratory \\ U.S. Army Engineer Research and Development Center \\ 3909 Halls Ferry Road \\ Vicksburg, MS 39180-6199
}

Final report

Approved for public release; distribution is unlimited 


\begin{abstract}
There are a number of proprietary rejuvenator, rejuvenator/sealer, and a seal coat materials currently available. It should be noted that throughout this report the term rejuvenator will be used to describe both rejuvenator and rejuvenator/sealer materials, because the primary purpose in this study was to use these materials to rejuvenate the asphalt pavement. Because of the proprietary nature of these materials, specifications that use performance-based requirements rather than material requirement specifications are highly preferred. One important requirement in the development of this type of specification is a field performance comparison of the various materials with known application and material property parameters.

The objective of this study was to investigate the comparative field performance of various rejuvenators and seal coat materials. The field performance of these materials was evaluated over a period of more than 1 year. The materials evaluated in this study were proprietary products. The study was not intended to determine the best or optimum rejuvenator or seal coat material but was intended to provide information for the development or updating of guide specifications for the use of these types of materials.

The scope of this study was to evaluate several types of coal-tar- and petroleum-based rejuvenators and seal coat materials. The materials were placed at two airfields and their effect on the binder properties of the treated pavement was compared to untreated areas. The field performance of the rejuvenator and seal coat materials was evaluated through their effects on skid resistance, texture, and changes on visual appearance. This report covers the placement and performance of the materials included in this study. To better evaluate the performance of both the rejuvenators and seal coat materials, the field sections should be periodically evaluated over the next several years. The guide specification for bituminous rejuvenation (Appendix C) should be used and evaluated in the U.S. Air Force project.

Additional investigation is required for further development of a test method for determining the effectiveness of a rejuvenator. This would involve the development of an effective means of aging both coal-tar- and asphalt-based rejuvenated asphalt cements. The rejuvenator and rejuvenator/sealer products that leave residual material on the pavement surface would require investigation to determine how much and what component of the product enters into the pavement to provide rejuvenation.
\end{abstract}

DISCLAIMER: The contents of this report are not to be used for advertising, publication, or promotional purposes. Citation of trade names does not constitute an official endorsement or approval of the use of such commercial products. All product names and trademarks cited are the property of their respective owners. The findings of this report are not to be construed as an official Department of the Army position unless so designated by other authorized documents. DESTROY THIS REPORT WHEN IT IS NO LONGER NEEDED. DO NOT RETURN TO THE ORIGINATOR. 


\section{Contents}

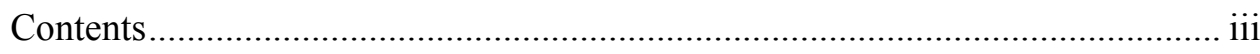

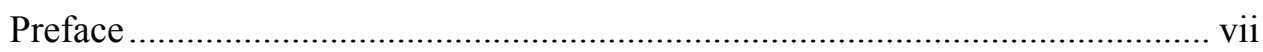

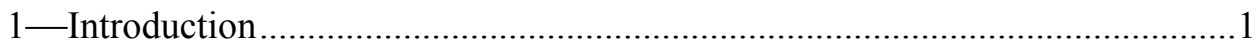

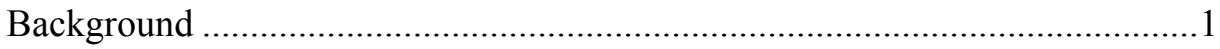

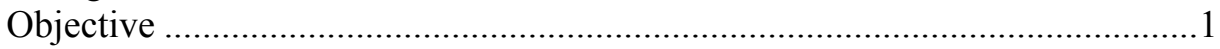

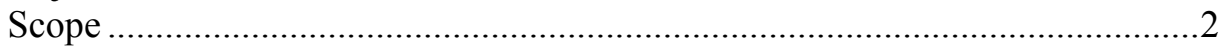

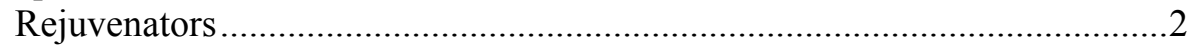

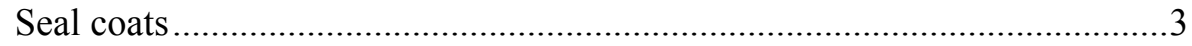

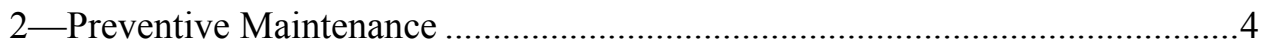

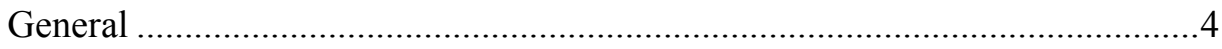

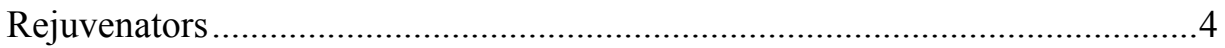

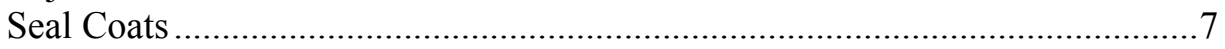

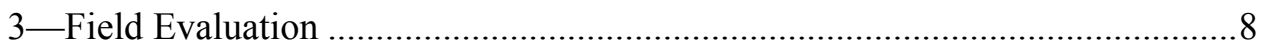

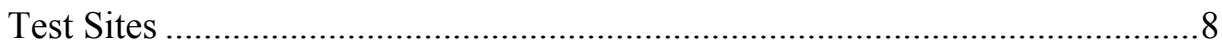

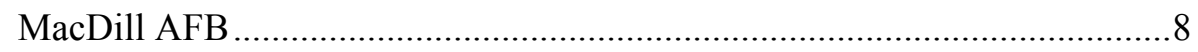

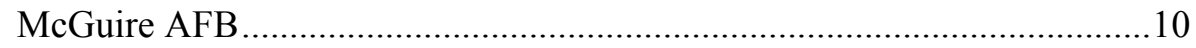

Existing Pavement Surface Conditions ...................................................... 10

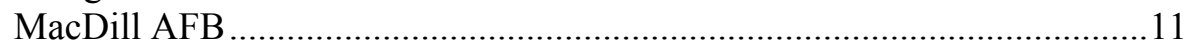

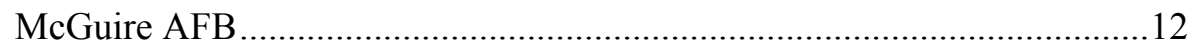

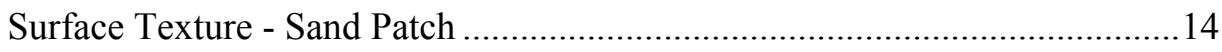

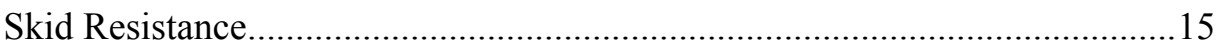

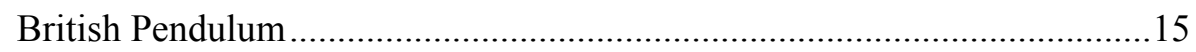

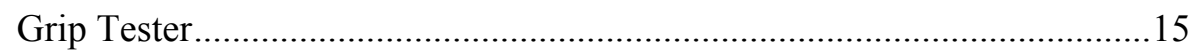

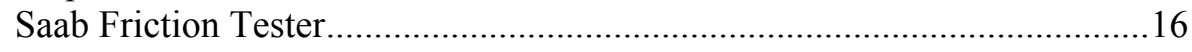

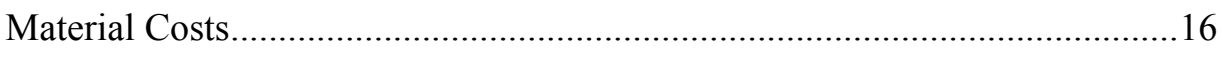

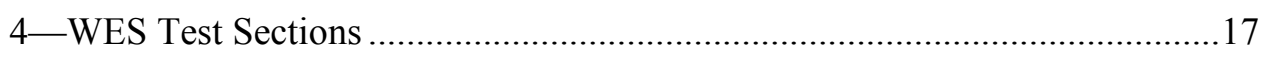

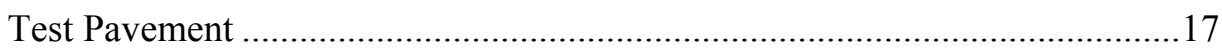

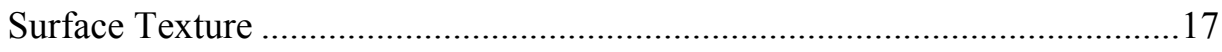

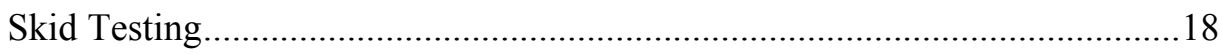

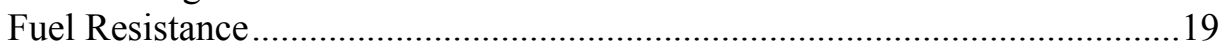

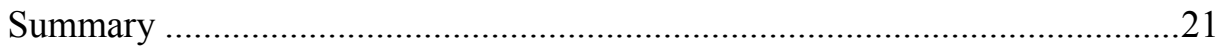




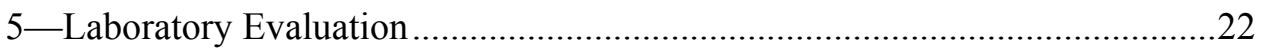

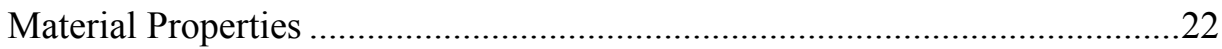

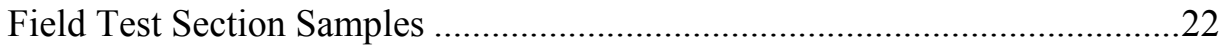

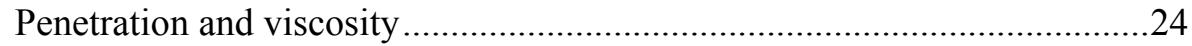

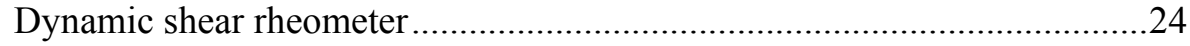

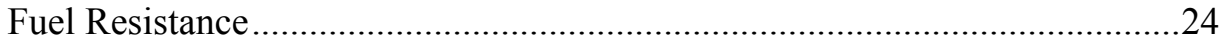

Artificially Aged-Rejuvenated Asphalt ........................................................26

Seal Coat Cohesive/Adhesive Properties ....................................................27

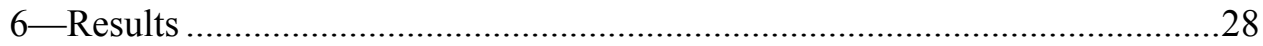

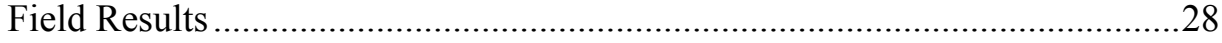

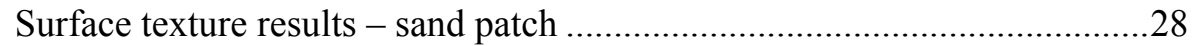

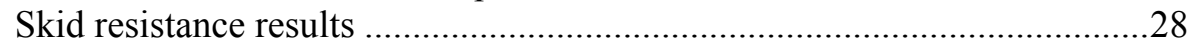

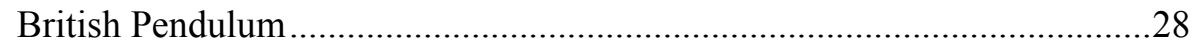

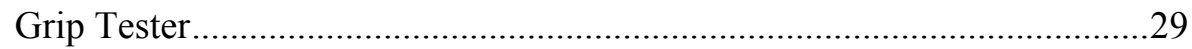

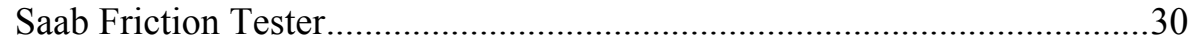

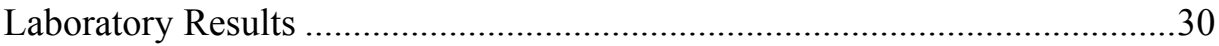

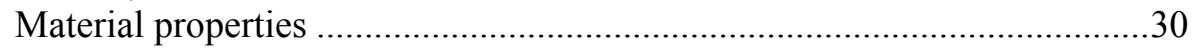

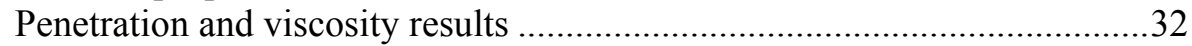

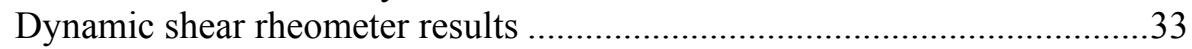

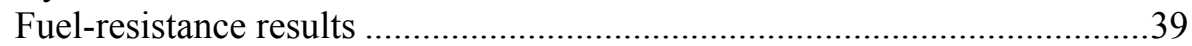

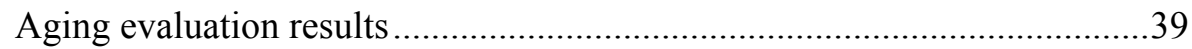

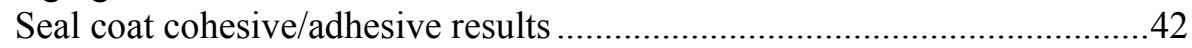

Rejuvenator and Seal Coat Performance Summary.......................................42

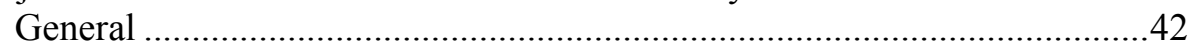

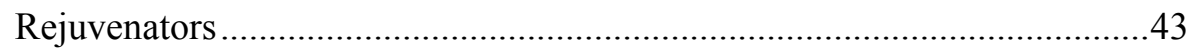

Seal coat performance summary.........................................................44

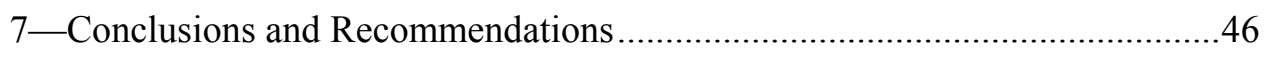

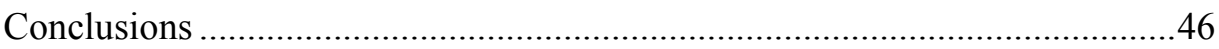

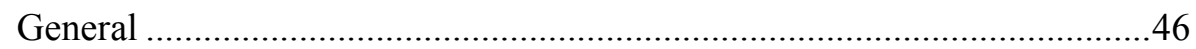

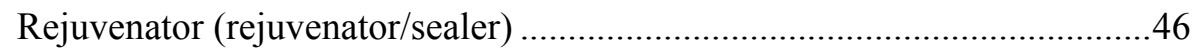

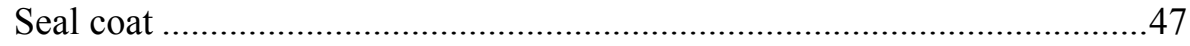

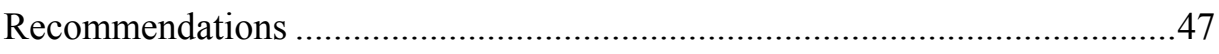

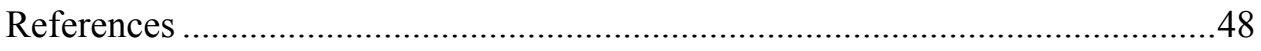

Figures 1-37

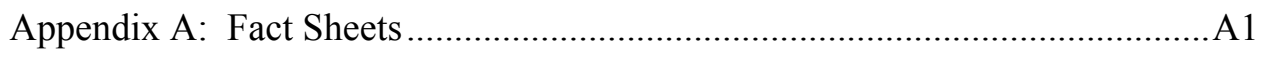

Appendix B: Fuel-Resistance Test Method.................................................... B1

Appendix C: Recommended Guide Specification ........................................... 1

SF 298 


\section{List of Tables}

Table 1. Materials Placed on TW O at MacDill AFB ......................................

Table 2. Materials Placed on TW M at MacDill AFB.....................................9

Table 3. Materials Placed at other Locations at MacDill AFB........................10

Table 4. Materials Placed on TW L at McGuire AFB ....................................11

Table 5. FAA Mu Value Guidelines for Wet Runway Surfaces ......................16

Table 6. Results of Tests on WES Field Test Sections.....................................18

Table 7. Properties of Pavement Used for Fuel Resistance Testing .................20

Table 8. Results of Fuel Resistance Testing on Uncoated HMA

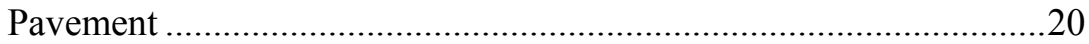

Table 9. Preparation of Field Cores from TW O at MacDill AFB …..............23

Table 10. Preparation of Field Cores from TW M at MacDill AFB ..................24

Table 11. Preparation of Field Cores from TW L at McGuire AFB .................25

Table 12. Rejuvenator Amounts for Given Additive Rates...............................26

Table 13. Results of Pavement Texture Tests on TW O at MacDill AFB ........29

Table 14. Results of Pavement Texture Tests on TW M at MacDill AFB.........30

Table 15. Results of Pavement Texture Tests on TW L at McGuire AFB.........31

Table 16. Results of British Pendulum Tests on TW O at MacDill AFB...........32

Table 17. Results of British Pendulum Tests on TW M at MacDill AFB ...........33

Table 18. Results of British Pendulum Tests on TW L at McGuire AFB ..........34

Table 19. Results of Grip Tester Friction Testing on TW O at MacDill

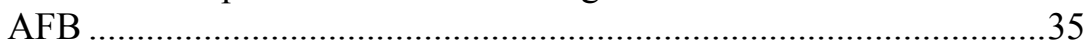

Table 20. Results of Grip Tester Friction Testing on TW M at MacDill AFB 36

Table 21. Results of Grip Tester and Saab Friction Testing on TW L at

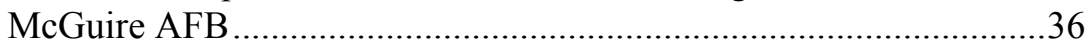

Table 22. Results of Material Properties Testing …............................................37

Table 23. Results of Tests on Recovered Asphalt of Field Cores from

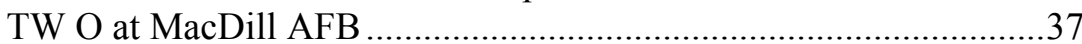


Table 24. Results of Tests on Recovered Asphalt of Field Cores from TW $M$ at MacDill AFB

Table 25. Results of Tests on Recovered Asphalt of Field Cores from TW L at McGuire AFB .38

Table 26. Results of Fuel-Resistance Tests on Field Cores from MacDill AFB 39

Table 27. Results of Fuel-Resistance Tests on Field Cores from McGuire AFB. .39

Table 28. Results of Artificially Aged (One PAV Cycle) Asphalt Cement with $0.158 \mathrm{~L} / \mathrm{m} 2$ (0.05 gsy) of Rejuvenator Added....

Table 29. Results of Artificially Aged (One PAV Cycle) Asphalt Cement with $0.316 \mathrm{~L} / \mathrm{m} 2$ (0.10 gsy) of Rejuvenator Added.

Table 30. Results of Artificially Aged (Two PAV Cycles) Asphalt Cement with $0.158 \mathrm{~L} / \mathrm{m} 2$ (0.05 gsy) of Rejuvenator Added. .41

Table 31. Results of Artificially Aged (Two PAV Cycles) Asphalt Cement with $0.316 \mathrm{~L} / \mathrm{m} 2$ (0.10 gsy) of Rejuvenator Added...........................42

Table 32. Tensile/Cohesive Strength of Seal Coat Mixtures. .43 


\section{Preface}

This report describes the results of field and laboratory evaluations conducted by the Geotechnical and Structures Laboratory (GSL), U.S. Army Engineering Research and Development Center (ERDC), Vicksburg, MS, for the Air Force Civil Engineering Support Agency (AFCESA). The study was conducted from October 1999 to March 2001. At the request of the sponsor, the report is being published under an ERDC cover as a technical report.

The study was conducted under the general supervision of Dr. David W. Pittman, acting Director, GSL. The report was written by Mr. James E. Shoenberger, GSL. The Air Force Technical Monitor was Mr. Jim Greene, AFCESA.

Commander and Executive Director of ERDC was COL John W. Morris III, EN. Director was Dr. James R. Houston. 


\section{Introduction}

\section{Background}

The U.S. Air Force has a large number of hot-mix asphalt (HMA) airfield pavements. The majority of distresses found on HMA airfield pavements, provided that the pavement is structurally sound, can be related to environmental effects (Hall et al. 1992). Therefore, the military has a great interest in materials or procedures that can decrease or delay the environmental distresses and extend the life of an HMA pavement. The environmental distresses that occur include: raveling and weathering, block cracking, and longitudinal and transverse cracking. These distresses occur because the asphalt cement that binds the pavement together ages or hardens with time because of oxidation and evaporation processes. Over time, this process causes a decrease in the ability of the binders to hold aggregate particles together (raveling), and it becomes unable to withstand the effects of thermal or moisture stresses (cracking). When these distresses become severe enough, they can cause foreign object damage (FOD) and a decrease in pavement serviceability that will reduce the life of the pavement. The U.S. Air Force would benefit from materials that can reduce the effects of aging through rejuvenation and from seal coat materials that can provide a durable trafficking surface.

There are a number of proprietary rejuvenator, rejuvenator/sealer, and seal coat materials currently available. It should be noted that throughout this report the term rejuvenator will be used to describe both rejuvenator and rejuvenator/ sealer materials, because the primary purpose in this study was to use these materials to rejuvenate the asphalt pavement. Because of the proprietary nature of these materials, specifications that use performance based requirements rather than material requirement specifications are highly preferred. One important requirement in the development of this type of specification is a field performance comparison of the various materials with known application and material property parameters.

\section{Objective}

The objective of this study was to investigate the comparative field performance of various rejuvenators and seal coat materials. The field performance of these materials was evaluated over a period of more than 1 year. The materials 
evaluated in this study were proprietary products. The study was not intended to determine the best or optimum rejuvenator or seal coat material but was intended to provide information for the development or updating of guide specifications for the use of these types of materials.

\section{Scope}

The scope of this study was to evaluate several types of coal-tar and petroleum-based rejuvenators and seal coat materials. The materials were placed at two airfields and their effect on the binder properties of the treated pavement was compared to untreated areas. The field performance of the rejuvenator and seal coat materials was evaluated through their effects on skid resistance, texture, and changes in visual appearance. This report covers the placement and performance of the materials included in this study.

\section{Rejuvenators}

The following is a listing of the rejuvenator materials evaluated as part of this study. The listing includes the product name, the classification of the base material, and the manufacturer's name and address. The material designation used throughout the report is given last in bold type.

a. Asphalt Rejuvenator 2000 (AR 2000); Coal-Tar Based Material; Vision Manufacturing/Protective Barriers, Inc., 350 Wentworth St. North, Hamilton, Ontario, L8L-5W3, Canada. AR-2000

b. Asphalt Pavement Rejuvenator (APR-100); Petroleum-Based Material; Mariani Asphalt Co., 5201 Causeway Blvd., Tampa, FL 33619. APR100

c. Bituminous Concrete Rejuvenator (BCR 2000); Coal-Tar Based Material; Pavement Depot Inc., 131 Willow St., Cheshire, CT 06410. BCR-2000

d. Bituminous Concrete Rejuvenator (BCR 3000); Coal-Tar Based Material (with proprietary rejuvenating oils); Pavement Depot Inc., 131 Willow St., Cheshire, CT 06410. BCR-3000

e. CBRT-SO; Coal-Tar Based Material; Mariani Asphalt Co., 5201 Causeway Blvd., Tampa, FL 33619. CBRT-SO

f. CPR - Conditioning Pavement Rejuvenator; Coal-Tar Based Material; Reeves Enterprises, Inc., 899 River Road, Selkirk, NY 12158. CPR

g. GSB - Modified; Petroleum-Based Material; Emulsified Asphalt (with proprietary rejuvenating oils and gilsonite); Asphalt Systems Inc., Salt Lake City, UT. GSB-mod 
h. Reclamite; Petroleum-Based Material; Golden Bear Oil Specialties, 10100 Santa Monica Blvd., Suite 1470, Los Angeles, CA 90067-4183. Reclamite

i. RejuvaSeal N; Coal-Tar Based Material; Echelon Industries Inc., 2557 Glenn Drive, Canyon Lake, TX 78133. RejuvaSeal N

j. RejuvaSeal 50; Coal-Tar Based Material (with proprietary rejuvenating oils); Echelon Industries Inc., 2557 Glenn Drive, Canyon Lake, TX 78133. RejuvaSeal 50

k. RejuvaSeal 500; Coal-Tar Based Material (with proprietary rejuvenating oils); Echelon Industries Inc., 2557 Glenn Drive, Canyon Lake, TX 78133. RejuvaSeal 500

\section{Seal coats}

The following is a listing of the seal coat materials evaluated as part of this study. The listing includes the product name, the classification of the base material, and the manufacturer's name and address. As with rejuvenators, the material designation used throughout the report is given last in bold type.

a. CRF; Petroleum-Based Pavement Sealer; Golden Bear Oil Specialties, 10100 Santa Monica Blvd., Suite 1470, Los Angeles, CA 90067-4183.

CRF

b. LAS-320, Liquid Asphalt Sealing Compound; 100 percent Polymeric Inorganic Acrylic Co-Polymers; Enviroseal Corp., 1021 SE Holbrook Ct., Port St. Lucie, FL 34952. LAS-320

c. Penetrating Asphalt Sealant (PAS); Petroleum-Based Sealant (Solvent Based); Mariani Asphalt Co., 5201 Causeway Blvd., Tampa, FL 33619. PAS

d. Polytar; Polymer Modified Coal-Tar Emulsion; Mariani Asphalt Co., 5201 Causeway Blvd., Tampa, FL 33619. PolyTar

e. ANTISKID (using PromaK A), Coal-Tar Based Sealer, Possehl Spezialbau GmbH, Rheinstraße 19, 65185 Wiesbaden, Germany. Antiskid 


\section{Preventive Maintenance}

\section{General}

Procedures used to prevent or minimize the effects of traffic and environmental damage on a pavement can be referred to as a preventive maintenance approach. This approach could involve the use of a rejuvenator to reenliven the surface asphalt or a seal coat to seal and protect the pavement surface. The preventive maintenance approach is cost effective because deterioration of an HMA pavement follows the general relationship as shown in Figure 1. This general relationship between a given serviceability index and years of service shows that, for a given time span, the serviceability drops faster as it decreases in value. Considering this figure, it has also been shown that short time delays in maintenance or repairs will result in substantial cost increases to achieve similar serviceability levels (Peterson 1985; Mamlouk and Zaniewski 1998).

\section{Rejuvenators}

Various manufacturers have produced materials for the rejuvenation of asphalt pavements for several decades. These materials have been developed and marketed by manufacturers as proprietary products. Webster defines rejuvenate or rejuvenator as to make young or youthful again or to restore to an original or new state (Webster 1977). An exact definition of what constitutes rejuvenation for asphalt pavements does not currently exist; however, most existing specifications concerning the use of these materials specify that the rejuvenator will reduce the stiffness of the asphalt cement on the surface or near the surface of the pavement. The material properties most often used to define the reduction in stiffness of the asphalt cement include penetration, viscosity, ductility, and recently dynamic shear rheometer (DSR) results.

\section{Test practices}

The current Corps of Engineers (CE), unified facilities guide specification (UFGS) for Bituminous Rejuvenation (UFGS 02787), requires that the asphalt cement recovered from the upper $9 \mathrm{~mm}(3 / 8 \mathrm{in}$.) of pavement shall have a decrease in viscosity of at least 40 percent. This is compared to recovered asphalt cement from cores taken from untreated areas or cores taken prior to 
rejuvenation. Research has shown that the majority of asphalt aging occurs in the top $12.5 \mathrm{~mm}$ (0.5 in.) of the pavement surface (Coons and Wright 1968).

Generally, the aging decreases exponentially from the surface until, at a depth of about $12.5 \mathrm{~mm}$ (0.5 in.), there is only minor additional aging with depth. For practical considerations, in order to obtain enough asphalt binder material to perform an extraction and recovery, a depth of HMA pavement of $9 \mathrm{~mm}(3 / 8 \mathrm{in}$.) to $12.5 \mathrm{~mm}(0.5 \mathrm{in}$.) is required. Depending upon the asphalt content of the HMA, using only the top $9 \mathrm{~mm}$ (3/8 in.) of the pavement will require three 150-mm (6-in.) cores to obtain enough material for one extraction and recovery. Conventional test methods such as penetration, viscosity, and ductility require relatively large amounts of binder when compared to that required for testing with a DSR. While the DSR requires a minimum amount of binder material, the limitations of the extraction and recovery methods require that a substantial amount of binder must be obtained.

\section{Past experience}

The current CE guide specification was developed from an U.S. Air Force sponsored study conducted about 25 years ago (Brown and Johnson 1976). It investigated the rejuvenation abilities of four different materials and an asphalt emulsion, used as a control. The study involved placing test strip applications of the materials at four different Air Force bases and monitoring these sites for 3 years. Rejuvenation was judged by a reduction in the viscosity or an increase in the penetration of the asphalt cement in the treated pavement. Three of the materials provided some rejuvenation of the asphalt binder in the pavements evaluated. One of the materials and the control emulsion provided no rejuvenation for the pavement. Reclamite, a petroleum-based emulsified rejuvenator, was a successful rejuvenator material from the previous study that was used in this study. Another acceptable rejuvenator from the previous study was Bituminous Pavement Rejuvenator (BPR). According to the manufacturer, BPR is still available but was not placed as part of this study.

A large number of rejuvenator products currently available are based on coaltar materials, and these are marketed as rejuvenator/sealers. These rejuvenator/ sealers leave a coating of material on the surface that acts to seal the surface. This coating should provide benefits commonly associated with seal coatings. The coal-tar materials in the rejuvenator/sealer provide some protection from fuel spills. The long-term ability of these rejuvenator/sealer materials to remain fuel resistant would appear to be tied to the amount of traffic to which the surface is exposed, since the traffic would eventually wear off this surface material. The other durability concern regarding coal-tar materials would be possible cracking, a frequent occurrence with coal-tar sealers (Shoenberger 2001).

There have only been a limited number of studies on rejuvenator materials for performance. There were several other studies in the 1970s, other than the study discussed above (Boyer 2000). These studies investigated some of the same rejuvenator materials investigated by the CE (Brown and Johnson 1976). The results of these studies were similar to those obtained in the CE study 
concerning the rejuvenating properties of two products known as Reclamite and BPR.

A recent evaluation of a coal-tar based rejuvenator/sealer product by the Florida State Materials Office (SMO) found the product unacceptable for highway applications (Sholar, Musselman, and Page 2000). The product was a proprietary material named SR-20. The SMO evaluated the product for about 1 month after placement, and they found that the product provided no appreciable rejuvenation. It may have been a suitable sealer but was unacceptable because of substantially lower skid resistance values when compared to nontreated pavement.

Unpublished data from the Missouri Department of Transportation (DOT), with the use of a coal-tar rejuvenator/sealer, indicated that repeated applications resulted in pavements with asphalt binders that were harder than in control sections. The treated pavements were cored, the top $12 \mathrm{~mm}$ ( $0.5 \mathrm{in}$.) was removed and extracted, and the asphalt was evaluated by ductility. Ductility tests after the second application showed a decrease in ductility when compared to a control section. The excess coal tar remaining on the surface following the first treatment had hardened. It was surmised that it had hardened to a degree that in coring to evaluate the second treatment, this hardened material was enough to decrease the ductility of the overall binder extracted from the surface. It was reported that the treated pavements continue to perform well 6 to 7 years after treatment (Shipman 2001).

There have been only a few spray applications of rejuvenating materials to pavement surfaces within the U.S. Military. One occurrence for the U.S. Air Force was on the runway and some taxiways at Lajes Field in the Azores. The rejuvenator Reclamite was applied to these pavements in 1979 and then again in 1983. The rejuvenation was judged effective, based upon an increase in penetration and a reduction in viscosity of the recovered asphalt cement after treatment (Pickett 1983). As a result of the concern over skid resistance and pavement texture differences in the traffic areas (rubber in the touchdown areas had recently been removed), the Reclamite was applied at various rates across the runway. Larger amounts were applied along the edges, with application rates about twice the amount of what was applied to the keel section of the runway.

The effect on skid resistance of any material or product that is applied to a pavement surface is important. The importance of skid resistance increases as the traffic speed on these pavements increases. The previously mentioned study (Brown and Johnson 1976) found that the application of rejuvenator materials to the pavement surface, at least in the short term (weeks or months), reduced the pavement's skid resistance. Reductions in skid resistance are also encountered with seal coats, unless an aggregate is used, and even with new HMA applications; the concern must be with the amount of decrease in skid resistance. 


\section{Seal Coats}

Seal coats have been used for many years to protect asphalt pavements from environmental damage and to improve the condition of a pavement surface. Seal coats act to protect the asphalt pavement by sealing out sunlight and liquid water. These products may also reduce the level of oxidation of an asphalt pavement by preventing the ready access of oxygen to the asphalt binder in the pavement. They also prevent water from penetrating into the pavement and causing problems with stripping. Stripping is a distress where in the presence of water, the asphalt lets go of the aggregate (or is stripped from the aggregate) causing raveling or weakening of the pavement structure. Usually, a seal coat is applied because of some distress on the pavement surface. While the seal coat improves or removes the distress, it also has the effect of protecting the underlying asphalt pavement. It was noted by base personnel at MacDill Air Force Base (AFB) that a seal coat (coal-tar sealer) applied to a part of a parking apron reduced the amount of block cracking (environmental distress) compared to an untreated area of the same parking apron (Gibson 2000).

A limitation on the type of seal coat that can be applied to an airfield pavement is the coating's ability to withstand high tire pressures and heavy loads while not introducing loose aggregate that could lead to FOD. The U.S. Air Force and Army currently require special approval prior to the use of a seal coat because of the concern over FOD potential. This concern is based not on sandsized aggregate particles but upon larger pieces of the seal coat (particularly a slurry) that could loosen and create an FOD hazard. Normally, to be considered an FOD hazard, the aggregate particles would have to have sufficient mass to cause damage to an engine or an aircraft. This allows individual sand-sized aggregate particles (at least at a minimal volume) not to be considered an FOD hazard.

Seal coats have in the past had minimal use on U.S. Air Force pavements, with only a few applications to taxiways and shoulder areas. In 1997 a seal coat (MicroSurfacing) was applied to the shoulder of the runway at MacDill AFB. This surfacing did receive traffic in the areas between the runway and cross taxiways without appreciable distress (Anderton and Shoenberger 1997). 


\section{Field Evaluation}

\section{Test Sites}

In order to properly evaluate the performance of each rejuvenator and seal coat material, test locations were desired in different climatic regions. Also, U.S. Air Force Bases with suitable pavements and a willingness to participate were required. The two bases selected were MacDill AFB, located in Tampa, FL, and McGuire AFB, located in south-central New Jersey. These bases climatically represent a hot and humid and a cold and humid region, respectively. Both of these bases belong to the Air Material Command (AMC).

The individual test sections were usually placed in 91.4-m (300-ft) lengths and in widths varying from 1.0 to $2.74 \mathrm{~m}$ ( 3.0 to $9 \mathrm{ft}$ ), depending upon the type of application equipment or method used. The length of $91.4 \mathrm{~m} \mathrm{(300 \textrm {ft } ) \text { was }}$ required to allow for later skid testing. Several manufacturers applied their materials at different application rates and some applied sand to the surface. The manufacturers were allowed to apply their materials in amounts and by methods selected by them. The test section areas of the taxiways used in the study were selected to be representative of typical surface conditions. Areas containing patches or other unusual surface defects were not used.

The pavements at the test sites were evaluated for their surface texture and skid resistance both before and after application of the materials. The locations for the surface texture were selected to best represent the changes that occurred as a result of the effect of applying the materials. Control sections that were untreated were used to determine the relative effect of the materials on the skid resistance of the pavement. The same basic procedures for the surface texture and skid resistance testing were followed at both test sites.

\section{MacDill AFB}

The materials were placed on taxiways (TW) M and O, both of which had existing recycled HMA surfaces that were placed either in the fall of 1984 or the spring of 1985 . The condition of these taxiways was very similar; both contained extensive low-to-medium severity block cracking, as defined in American Society for Testing and Materials (ASTM) D 5340 (ASTM 2000a), Figures 2, 3, 4 , and 5. Neither taxiway is normally used as a main taxiway, which was a condition that allowed them to be closed for test section application and later 
evaluation. However, both taxiways do receive some traffic that will vary with aircraft deployments at the base. The C-141 (large cargo aircraft) and the KC-135 (tanker) are the predominate aircraft at MacDill AFB. In addition, there is a wide variety of other aircraft, including C-130s and smaller fighter aircraft. Their respective manufacturers applied the various rejuvenator, rejuvenator/ sealer, and seal coat materials on taxiways $\mathrm{M}$ and $\mathrm{O}$. Tables 1, 2, and 3 provide details on the materials placed at MacDill AFB. Two materials, Antiskid and Conditioning Pavement Rejuvenator (CPR), were placed a few months after the other materials. Figures 6 and 7 show schematic diagrams of the areas and section application locations on each taxiway. Figures 8 and 9 show the test sections on the taxiways within a few days of placement. Figure 10 shows Taxiway $\mathrm{O}$ after placement of the Antiskid seal coat system. Figures 11, 12, and 13 show some of the types of equipment that were used to place the materials.

\begin{tabular}{|c|c|c|c|c|c|c|}
\hline \multicolumn{7}{|c|}{$\begin{array}{l}\text { Table } 1 \\
\text { Materials Placed on TW O at MacDill AFB }\end{array}$} \\
\hline Material & $\begin{array}{l}\text { Date }{ }^{1} \\
\text { Applied }\end{array}$ & Area $^{2}$ & Section $^{2}$ & $\begin{array}{l}\text { Dimensions, } \\
\mathrm{L} / \mathbf{W}, \mathbf{m}(\mathrm{ft})\end{array}$ & 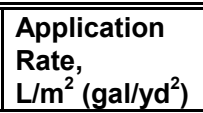 & $\begin{array}{l}\text { Sand, } \\
\mathbf{k g} / \mathbf{m}^{2} \\
\left(\mathrm{lb} / \mathrm{yd}^{2}\right)\end{array}$ \\
\hline \multirow[t]{2}{*}{ BCR-2000 } & \multirow[t]{2}{*}{$7 / 13$} & \multirow[t]{3}{*}{1} & A & \multirow[t]{3}{*}{$\overline{91.4 / 2.1(300 / 7)}$} & \multirow[t]{3}{*}{$0.158(0.05)$} & ${\overline{---{ }^{3}}}^{3}$ \\
\hline & & & $\mathrm{B}$ & & & $0.54(1.0)$ \\
\hline BCR-3000 & $7 / 13$ & & $\mathrm{C}$ & & & --- \\
\hline $\begin{array}{l}\text { RejuvaSeal } \\
50\end{array}$ & $7 / 13$ & \multirow[t]{3}{*}{2} & A & \multirow[t]{3}{*}{$91.4 / 2.1(300 / 7)$} & \multirow[t]{3}{*}{$0.158(0.05)$} & --- \\
\hline \multirow{2}{*}{$\begin{array}{l}\text { RejuvaSeal } \\
N\end{array}$} & \multirow[t]{2}{*}{$7 / 13$} & & $\mathrm{~B}$ & & & $0.54(1.0)$ \\
\hline & & & $\mathrm{C}$ & & & --- \\
\hline \multirow[t]{3}{*}{ Reclamite } & \multirow[t]{3}{*}{$7 / 20$} & \multirow[t]{4}{*}{3} & $\mathrm{~A}$ & \multirow[t]{3}{*}{$91.4 / 2.4(300 / 8)$} & $0.285(0.09)$ & --- \\
\hline & & & $\mathrm{B}$ & & $0.206(0.065)$ & --- \\
\hline & & & $\mathrm{C}$ & & $0.158(0.05)$ & $\begin{array}{ll}-- \\
-\end{array}$ \\
\hline Antiskid & $2 / 22 / 01$ & & $\mathrm{D}$ & $91.4 / 1.0(300 / 3)$ & & $12(22.2)$ \\
\hline \multirow[t]{3}{*}{ GSB-mod } & \multirow[t]{3}{*}{$7 / 17$} & \multirow[t]{3}{*}{4} & $\mathrm{~A}$ & \multirow[t]{3}{*}{$91.4 / 2.4(300 / 8)$} & $0.443(0.14)$ & \multirow[t]{3}{*}{$0.33(0.6)$} \\
\hline & & & $\mathrm{B}$ & & $0.411(0.13)$ & \\
\hline & & & $\mathrm{C}$ & & $0.380(0.12)$ & \\
\hline \multicolumn{7}{|c|}{$\begin{array}{l}\text { Dates given are for year } 2000 \text { unless otherwise defined. } \\
2 \text { Defined in Figure } 6 \text {. } \\
3 \text { Dashed lines indicate that no sand was added to mixtures. } \\
{ }^{4} \text { Construction sequence consisted of a prime coat at } 0.25 \mathrm{~kg} / \mathrm{m}^{2}\left(0.46 \mathrm{lb} / \mathrm{yd}^{2}\right)(\text { with Brocat A } \\
\text { material diluted with equal amounts of water). Applying Promac A at a rate of } 1.7 \mathrm{~kg} / \mathrm{m}^{2} \\
\left(3.15 \mathrm{lb} / \mathrm{yd}^{2}\right) \text {, followed by the sand and then an evenly diluted seal coat of Brocat A at } 0.25 \mathrm{~kg} / \mathrm{m}^{2} \\
\left(0.46 \mathrm{lb} / \mathrm{yd}^{2}\right) \text {. }\end{array}$} \\
\hline
\end{tabular}

\begin{tabular}{|c|c|c|c|c|c|c|}
\hline \multicolumn{7}{|c|}{$\begin{array}{l}\text { Table } 2 \\
\text { Materials Placed on TW M at MacDill AFB }\end{array}$} \\
\hline Material & $\begin{array}{l}\text { Date } \\
\text { Applied } \\
(2000) \\
\end{array}$ & Area $^{1}$ & Section $^{1}$ & $\begin{array}{l}\text { Dimensions, } \\
\mathrm{L} / \mathrm{W}, \mathrm{m}(\mathrm{ft})\end{array}$ & 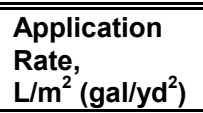 & $\begin{array}{l}\text { Sand, } \\
\mathrm{kg} / \mathrm{m}^{2} \\
\left(\mathrm{Ib} / \mathrm{yd}^{2}\right)\end{array}$ \\
\hline \multirow[t]{2}{*}{ PolyTar } & \multirow[t]{2}{*}{$7 / 7 / 20$} & \multirow[t]{2}{*}{ 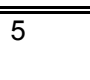 } & A & \multirow[t]{2}{*}{ 91.4/2.1(300/7) } & $0.904(0.20)$ & $360(3)^{3}$ \\
\hline & & & $\mathrm{B}$ & & $0.904(0.20)$ & $360(3+)^{2,3,4}$ \\
\hline CBRT-SO & $7 / 20$ & \multirow[t]{2}{*}{6} & $A$ & $91.4 / 2.1(300 / 7)$ & $0.206(0.065)$ & $0.27(0.5)$ \\
\hline PAS & $7 / 20$ & & $\mathrm{~B}$ & $82.3 / 2.1(270 / 7)$ & $0.190(0.06)$ & $--^{2}$ \\
\hline APR-100 & $7 / 20$ & 7 & $\mathrm{~A}$ & $91.4 / 2.1(300 / 7)$ & $0.190(0.06)$ & --- \\
\hline CBRT-SO & $7 / 20$ & 8 & $\mathrm{~A}$ & $91.4 / 2.1(300 / 7)$ & $0.206(0.065)$ & --- \\
\hline CPR & $11 / 4$ & 10 & $\mathrm{~A}$ & $91.4 / 2.1(300 / 7)$ & $0.158(0.05)$ & --- \\
\hline \multicolumn{7}{|c|}{$\begin{array}{l} \\
2 \text { No material placed in area } 9 . \\
2 \text { Dashed lines indicate that no sand was added to mixtures. } \\
{ }^{3} \text { Coal-tar emulsion was batched; sand given as kg/liter (lb/gal) of emulsion. } \\
{ }^{4} \text { Some additional sand was blown over from area } 7 .\end{array}$} \\
\hline
\end{tabular}




\begin{tabular}{|c|c|c|c|c|c|}
\hline \multicolumn{6}{|c|}{$\begin{array}{l}\text { Table } 3 \\
\text { Materials Placed at other Locations at MacDill AFB }\end{array}$} \\
\hline Material & \begin{tabular}{|l|} 
Date \\
Applied \\
2000 \\
\end{tabular} & Location & $\begin{array}{l}\text { Dimensions, } \\
\text { L/W, } m(\mathrm{ft})\end{array}$ & $\begin{array}{l}\text { Application Rate, } \\
\mathrm{L} / \mathrm{m}^{2}\left(\mathrm{gal} / \mathrm{yd}^{2}\right)\end{array}$ & $\begin{array}{l}\text { Sand, } \\
\mathrm{kg} / \mathrm{m}^{2}\left(\mathrm{lb} / \mathrm{yd} \mathrm{d}^{2}\right)\end{array}$ \\
\hline \multirow[t]{2}{*}{$\overline{\text { Reclamite }}$} & \multirow[t]{2}{*}{ 7/20 } & $\begin{array}{l}1,504^{\prime} \text { from } \\
\text { S.E. end TW N }\end{array}$ & "31.7/2.4 (104/8) & $0.254(0.08)$ & "---1 \\
\hline & & $\begin{array}{l}1,700^{\prime} \text { from } \\
\text { S.E. end TW N }\end{array}$ & 32.6/2.4 (107/8) & $0.317(0.10)$ & $--^{-1}$ \\
\hline \multirow[t]{2}{*}{$\mathrm{CRF}^{2}$} & \multirow[t]{2}{*}{$7 / 20$} & \multirow[t]{2}{*}{ South Apron } & $110 / 2.4(360 / 8)$ & $0.380(0.12)$ & $0.11(0.20)$ \\
\hline & & & $30.5 / 2.4(100 / 8)$ & $0.634(0.20)$ & $0.11(0.20)$ \\
\hline
\end{tabular}

\section{McGuire AFB}

The materials were placed on Taxiway L which, according to U.S. Air Force condition survey reports, had been last overlaid in 1994. The pavement contains some areas of alligator cracking and rutting and other areas with low-severity block cracking (Figures 14, 15, and 16). This taxiway is the main parallel taxiway from the main parking apron and it receives a relatively high amount of traffic. The C-10 (large tanker aircraft) and the C-141 (large cargo aircraft) are the predominate aircraft at McGuire AFB. Additionally, there are a wide variety of smaller aircraft. Their respective manufacturers applied the various rejuvenator, rejuvenator/sealer, and seal coat materials on Taxiway L. Table 4 provides details on the materials placed at McGuire AFB. Figure 17 shows a schematic drawing of the areas and section application locations on the taxiway. Figure 18 shows the test sections on the taxiway about 4 weeks after placement. Figures 19 and 20 show some of the types of equipment that were used to place various materials.

\section{Existing Pavement Surface Conditions}

A description of the surface distresses existing on each pavement section was recorded prior to placement of the various materials. No significant differences in performance were noted for the various materials; however, with an evaluation period of only 1 year, this was not unexpected. It is anticipated that it would take a visual evaluation 3 to 4 years after application to quantify the effect of the various materials on pavement performance.

One area of visual difference that could be noted was the overall color or amount of material left on the pavement surface. Within a few months it was almost impossible to detect the location of the Reclamite test strips on the pavement. The APR-100 material also lightened considerably but was still very visible. On the whole, the petroleum-based materials all lightened more than the coal-tar materials. 


\begin{tabular}{|c|c|c|c|c|c|c|}
\hline \multicolumn{7}{|c|}{$\begin{array}{l}\text { Table } 4 \\
\text { Materials Placed on TW L at McGuire AFB }\end{array}$} \\
\hline Material & $\begin{array}{l}\text { Date }^{1} \\
\text { Applied }\end{array}$ & Area $^{2}$ & Section ${ }^{2}$ & $\begin{array}{l}\text { Dimensions } \\
\text { L/W, m (ft) }\end{array}$ & $\begin{array}{l}\text { Application } \\
\text { Rate, } \\
\text { L/m } / \mathrm{m}^{2}\left(\mathrm{gal} / \mathrm{yd}^{2}\right) \\
\end{array}$ & $\begin{array}{l}\text { Sand, } \\
\mathrm{kg} / \mathrm{m}^{2} \\
\left(\mathrm{Ib} / \mathrm{yd}^{2}\right)\end{array}$ \\
\hline \multirow[t]{4}{*}{ GSB-mod } & \multirow[t]{4}{*}{$7 / 31$} & \multirow[t]{4}{*}{1} & A & \multirow[t]{4}{*}{$91.4 / 2.4(300 / 8)$} & $0.586(0.185)$ & \multirow[t]{4}{*}{$0.33(0.6)$} \\
\hline & & & \begin{tabular}{|l}
$\mathrm{B}$ \\
\end{tabular} & & \begin{tabular}{|l}
$0.522(0.165)$ \\
\end{tabular} & \\
\hline & & & $\mathrm{C}$ & & $0.427(0.135)$ & \\
\hline & & & $\mathrm{D}$ & & $0.633(0.20)$ & \\
\hline \multirow[t]{3}{*}{ RejuvaSeal N } & \multirow[t]{3}{*}{$8 / 2$} & \multirow[t]{3}{*}{2} & $A$ & \multirow[t]{3}{*}{$91.4 / 2.4(300 / 8)$} & $0.158(0.05)$ & $0.54(1.0)$ \\
\hline & & & $\mathrm{B}$ & & $0.158(0.05)$ & $--^{3}$ \\
\hline & & & $\mathrm{F}$ & & $0.190(0.06)$ & --- \\
\hline \multirow[t]{3}{*}{ BCR-2000 } & \multirow[t]{3}{*}{$8 / 2$} & \multirow[t]{3}{*}{2} & C & \multirow[t]{3}{*}{$91.4 / 2.4(300 / 8.5)$} & $0.190(0.06)$ & --- \\
\hline & & & $\mathrm{D}$ & & $0.158(0.05)$ & $0.54(1.0)$ \\
\hline & & & $\mathrm{E}$ & & $0.158(0.05)$ & --- \\
\hline \multirow[t]{4}{*}{ Reclamite } & \multirow[t]{4}{*}{$8 / 4$} & \multirow[t]{4}{*}{3} & A & \multirow[t]{4}{*}{$91.4 / 2.6(300 / 8.5)$} & $0.475(0.15)$ & --- \\
\hline & & & $\mathrm{B}$ & & $0.317(0.10)$ & --- \\
\hline & & & $\mathrm{C}$ & & $0.253(0.08)$ & --- \\
\hline & & & $\mathrm{D}$ & & $0.190(0.06)$ & --- \\
\hline \multirow{3}{*}{\begin{tabular}{|l} 
Poly lar \\
CBTR-SO
\end{tabular}} & $8 / 4$ & \multirow[t]{6}{*}{4} & A & $91.4 / 2.7(300 / 9)$ & $0.904(0.20)$ & --- \\
\hline & $8 / 4$ & & $\mathrm{~B}$ & \multirow[t]{5}{*}{$91.4 / 2.3(300 / 7.5)$} & $0.174(0.055)$ & --- \\
\hline & & & $\mathrm{C}$ & & $0.177(0.056)$ & $0.27(0.5)$ \\
\hline PAS & $8 / 4$ & & $\mathrm{D}$ & & $0.218(0.069)$ & --- \\
\hline \multirow[t]{2}{*}{ CPR } & \multirow[t]{2}{*}{$6 / 19 / 01$} & & $\mathrm{E}$ & & $0.253(0.08)$ & --- \\
\hline & & & $\mathrm{F}$ & & $0.222(0.07)$ & --- \\
\hline $\begin{array}{l}\text { RejuvaSeal } \\
500\end{array}$ & \multirow[t]{2}{*}{$8 / 23$} & \multirow[t]{4}{*}{5} & A & \multirow[t]{2}{*}{$91.4 / 2.4(300 / 8)$} & $0.158(0.05)$ & --- \\
\hline BCR-3000 & & & $\mathrm{B}$ & & $0.158(0.05)$ & --- \\
\hline \multirow[t]{2}{*}{ AR-2000 } & \multirow[t]{2}{*}{$8 / 23$} & & \begin{tabular}{|l}
$\mathrm{C}$ \\
\end{tabular} & $18.3 / 2.4(60 / 8)$ & $0.228(0.072)$ & --- \\
\hline & & & $\mathrm{D}$ & $31.1 / 2.4(102 / 8)$ & $0.162(0.051)$ & --- \\
\hline \begin{tabular}{|l|} 
LAS-320 \\
\end{tabular} & $10 / 11$ & \multirow[t]{3}{*}{6} & $\mathrm{~A}$ & $45.7 / 2.4(150 / 8)$ & $0.158(0.05)$ & --- \\
\hline APR-100 & $8 / 4$ & & \begin{tabular}{|l|}
$\mathrm{B}$ \\
\end{tabular} & $91.4 / 2.3(300 / 7.5)$ & $0.218(0.069)$ & --- \\
\hline \multirow[t]{2}{*}{ CPR } & \multirow[t]{2}{*}{$6 / 19 / 01$} & & $\mathrm{C}$ & $91.4 / 2.3(300 / 7.5)$ & $0.190(0.06)$ & --- \\
\hline & & 8 & $A$ & & $0.158(0.05)$ & --- \\
\hline
\end{tabular}

\section{MacDill AFB}

The test strips 1 through 4 at MacDill AFB were placed on Taxiway $\mathrm{O}$ as shown in Figure 6. The descriptions of the surface distresses for each test strip are given below.

a. 1C: Block cracked throughout, most cracks $<3 \mathrm{~mm}(1 / 8$ in.) wide, one or two aggregate pieces missing every $0.3 \mathrm{~m}^{2}\left(1 \mathrm{ft}^{2}\right)$.

b. 2A: Block cracked throughout, most cracks $<3 \mathrm{~mm}(1 / 8 \mathrm{in}$.) wide, two or four aggregate pieces missing every $0.3 \mathrm{~m}^{2}\left(1 \mathrm{ft}^{2}\right)$, more surface voids on side toward center line.

c. 3C: Block cracked throughout, all cracks $<3 \mathrm{~mm}(1 / 8 \mathrm{in}$.) wide.

d. 4A: Block cracked over about 70 percent of the area, most cracks $<3 \mathrm{~mm}$ (1/8 in.) wide, open longitudinal construction joint - full length 
of test strip - width about $4.5 \mathrm{~mm}$ (3/16 in.), many missing pieces of aggregate - less than other strips on taxiway.

The test strips 5 through 10 at MacDill AFB were placed on Taxiway M as shown in Figure 7. The descriptions of the surface distresses for each test strip are given below.

a. 5A: Block cracked throughout, cracks 3 to $6 \mathrm{~mm}$ (1/8 to $1 / 4$ in.) wide, some missing aggregate in cracks.

b. 5B: Block cracked throughout, $26 \mathrm{~m}(85 \mathrm{ft})$ of open longitudinal construction joint on northwest end, most cracks $<3 \mathrm{~mm}$ ( $1 / 8 \mathrm{in}$.), with some up to $6 \mathrm{~mm}(1 / 4 \mathrm{in}$.) wide, some missing aggregate in cracks.

c. 6A: Block cracked throughout, most cracks $<6 \mathrm{~mm}$ (1/4 in.), open longitudinal construction joint - full length of test strip, some missing aggregate in cracks.

d. 6B: Block cracked throughout (not as noticeable on center one-third of strip), cracks 6 to $9.5 \mathrm{~mm}$ (1/4 to 3/8 in.) wide, some missing aggregate in cracks.

e. 7A: About $14 \mathrm{~m} \mathrm{(45} \mathrm{ft)} \mathrm{of} \mathrm{mostly} \mathrm{transverse} \mathrm{cracking,} \mathrm{most}<3 \mathrm{~mm}$ ( $1 / 8$ in.) wide

f. 8A: About $28 \mathrm{~m}(92 \mathrm{ft})$ of longitudinal and transverse cracking, open longitudinal construction joint - full length of strip, most cracks $<3 \mathrm{~mm}$ (1/8 in.) wide.

g. 10A: Block cracked on last one-third of strip on northwest end, $36.5 \mathrm{~m}$ $(120 \mathrm{ft})$ of open longitudinal construction joint on southeast end, only a few cracks in the remainder of the strip, most cracks $<3 \mathrm{~mm}(1 / 8 \mathrm{in}$.).

The following is a description of the pavement condition where the seal coat material CRF was placed on the south apron. This strip is on pavement in a closed section of the parking apron. The pavement surface of this area was very raveled with large aggregates somewhat exposed. The CRF seal coat process involves a spray application of the diluted CRF emulsion (60 percent CRF and 40 percent water) followed by an application of clean crushed screenings that are worked into the surface Figures 21 and 22. The CRF material and the fines were placed to fill in the voids around the exposed large aggregate of the apron pavement surface. After 1 year, there appeared to be more fines around the aggregates in the treated strip, but no other differences were noted.

\section{McGuire AFB}

The test sections at McGuire AFB were placed on Taxiway $\mathrm{L}$ as shown in Figure 17. The descriptions of the surface distresses for each test strip follow: 
a. 1A: About $113 \mathrm{~m}(370 \mathrm{ft})$ of longitudinal and transverse cracking, some may be block cracking, most $<3 \mathrm{~mm}(1 / 8 \mathrm{in}$.) wide, with some up to $19 \mathrm{~mm}(3 / 4 \mathrm{in}$.$) .$

b. 1B: About $97.5 \mathrm{~m}(320 \mathrm{ft})$ of longitudinal and transverse cracking, some may be block cracking, most $<3 \mathrm{~mm}$ (1/8 in.) wide, with some aggregate missing from cracks.

c. 1C: Block cracked throughout, cracks generally $<3 \mathrm{~mm}(1 / 8 \mathrm{in}$.) wide, with some aggregate missing from cracks.

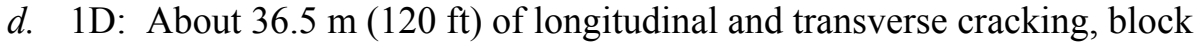
cracking throughout longitudinal center third, most cracks $<3 \mathrm{~mm}$ (1/8 in.) wide, with some aggregate missing from cracks; open longitudinal construction joint - full length of test strip (generally $<3 \mathrm{~mm}$ (1/8 in.) wide).

e. 2A: Block cracked throughout, cracks generally $<3 \mathrm{~mm}(1 / 8 \mathrm{in}$.) wide, block size varies from $0.3 \times 0.3 \mathrm{~m}$ to 0.6 to $1.2 \mathrm{~m}(1 \times 1 \mathrm{ft}$ to $2 \times 4 \mathrm{ft})$.

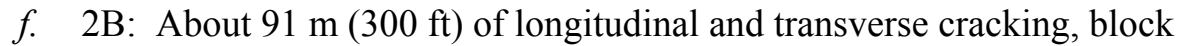
cracking throughout longitudinal third of strip toward center line, most cracks $<3 \mathrm{~mm}$ (1/8 in.) wide, with some crack widths up to $19 \mathrm{~mm}$ (3/4 in.), generally on longitudinal side toward center line.

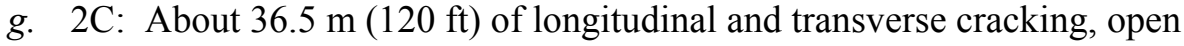
longitudinal construction joint $-61 \mathrm{~m}(200 \mathrm{ft})$ long, most cracks $\geq 6 \mathrm{~mm}$ (1/4 in.) wide.

h. 2D: About $73 \mathrm{~m}(240 \mathrm{ft})$ of longitudinal and transverse cracking, open longitudinal construction joint $-61 \mathrm{~m}(200 \mathrm{ft})$ long, most cracks $<3 \mathrm{~mm}$ (1/8 in.) wide, with some up to $6 \mathrm{~mm}$ (1/4 in.) wide.

i. 2E: About $39 \mathrm{~m}(128 \mathrm{ft})$ of longitudinal and transverse cracking, most cracks $<3 \mathrm{~mm}$ (1/8 in.) wide, with some up to $9.5 \mathrm{~mm}$ (3/8 in.) wide.

j. 2F: About $27.5 \mathrm{~m}(90 \mathrm{ft})$ of mainly transverse cracking, most cracks $<3 \mathrm{~mm}$ (1/8 in.) wide, with some up to $9.5 \mathrm{~mm}$ (3/8 in.) wide.

k. 3A: About $42.5 \mathrm{~m}(140 \mathrm{ft})$ of longitudinal and transverse cracking, most cracks $<3 \mathrm{~mm}(1 / 8 \mathrm{in}$.) wide, with one full-width transverse crack $12.5 \mathrm{~mm}(1 / 2$ in. $)$ wide.

l. 3B: About $22 \mathrm{~m}(72 \mathrm{ft})$ of longitudinal and transverse cracking, most cracks $<3 \mathrm{~mm}(1 / 8 \mathrm{in}$.) wide, with one full-width transverse crack $12.5 \mathrm{~mm}(1 / 2 \mathrm{in}$.) wide.

m. 3C: Completely block cracked, most cracks $<3 \mathrm{~mm}$ (1/8 in.) wide with some aggregate missing from cracks, block size varies from $0.3 \times 0.3 \mathrm{~m}$ to $1 \times 1.5 \mathrm{~m}(1 \times 1 \mathrm{ft}$ to $3 \times 5 \mathrm{ft})$. 
$n$. 3D: Block cracked from center of strip toward center line of taxiway, about $14 \mathrm{~m}$ (45 ft) of transverse cracking, most cracks $<3 \mathrm{~mm}(1 / 8 \mathrm{in}$.) wide with some aggregate missing from cracks.

o. 4A: Block cracked over about 75 percent of the area - worse toward center line and longitudinal construction joint, most cracks $<3 \mathrm{~mm}$ (1/8 in.) wide, with some aggregate missing from cracks.

p. 4B: About $36.5 \mathrm{~m}(120 \mathrm{ft})$ of mainly transverse cracking, block cracked over about 25 percent of area - around longitudinal construction joint closest to center line, $46 \mathrm{~m}$ (150 ft) of cracked longitudinal construction joint, most cracks $<3 \mathrm{~mm}$ (1/8 in.) wide.

q. 4C: About $91 \mathrm{~m}(300 \mathrm{ft})$ of mainly transverse cracking, most cracks $<3 \mathrm{~mm}(1 / 8 \mathrm{in}$.) wide, with some aggregate missing from cracks.

r. 4D: About $46 \mathrm{~m}(150 \mathrm{ft})$ of mainly transverse cracking, most cracks $<3 \mathrm{~mm}$ (1/8 in.) wide, with some aggregate missing from cracks, one transverse crack about $6 \mathrm{~mm}(1 / 4 \mathrm{in}$.) wide.

s. 4F: About $131 \mathrm{~m} \mathrm{(430} \mathrm{ft)} \mathrm{of} \mathrm{longitudinal} \mathrm{and} \mathrm{transverse} \mathrm{cracking,}$ mainly on southeast end of strip, most cracks $<3 \mathrm{~mm}$ (1/8 in.) wide.

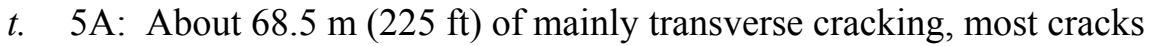
$<3 \mathrm{~mm}(1 / 8 \mathrm{in}$. $)$ wide.

u. 5C: Block cracked over about 80 percent of area, cracked full length along longitudinal construction joint, two small transverse cracks, most cracks $<3 \mathrm{~mm}(1 / 8 \mathrm{in}$.) wide.

v. 6A: Block cracked over about 70 percent of area, two small transverse cracks, most cracks $<3 \mathrm{~mm}(1 / 8 \mathrm{in}$.) wide.

w. 6B: About $26 \mathrm{~m}(85 \mathrm{ft})$ of longitudinal and transverse cracking, most cracks $<3 \mathrm{~mm}(1 / 8 \mathrm{in}$.) wide.

\section{Surface Texture - Sand Patch}

The pavements texture is important, as it effects skid resistance and rideability of a pavement. Texture can be defined as the surface features of the pavement dependent on the size, shape, arrangement, and distribution of component materials. The amount or depth of texture has a correlation to the skid resistance of a pavement (Haas, Hudson, and Zaniewski 1994). Texture considerations for skid resistance can be broken down into microtexture (texture of individual aggregate particles) and macrotexture (tire/stone interface) components. The sand patch test provides a measure of the macrotexture or depth of the texture of the pavement. 
The relative surface texture of the pavement at each test section was determined using a sand patch test, conducted in accordance with ASTM E 965 (ASTM 2000b). Figure 23 shows a typical sand patch test layout. The aggregate used was Ottawa natural silica sand, passing the $300 \mu \mathrm{m}$ (No. 50) sieve and retained in the $150 \mu \mathrm{m}$ (No. 100) sieve. A mean texture depth was not determined since all tests were conducted using the same volume and type of sand. Therefore, the diameter of the sand patch obtained from each test was directly comparable to all other tests conducted. Representative uncoated areas were tested for comparison purposes. A decrease in the diameter would indicate an increase in texture and, therefore, improved skid resistance properties. All areas were cleaned with a soft-bristle brush to remove loose particles prior to the testing. A light wire brushing for cleaning was applied only to the control (uncoated) sections of the pavement surface tested.

\section{Skid Resistance}

Skid resistance is an important safety concern for all high-speed pavement applications including: runways, high-speed taxiways, and roadways. Previously discussed research has shown a reduction in skid resistance with the application of some materials. In general, unless an aggregate (sand) is added, an application of any bituminous material will tend, at least in the short term, to lower a pavement's skid resistance. The skid resistance of most HMA pavements is relatively low immediately after construction and it will tend to improve with age and traffic. Aging will eventually lead to some minor raveling that will increase the pavements macrotexture and thereby improve the skid resistance. Traffic will wear off the asphalt binder from the surface aggregate, and allow the microtexture of the aggregates to increase the skid resistance of the pavements.

\section{British Pendulum}

An evaluation of skid resistance was conducted on each type of material using the British Pendulum in accordance with ASTM E 303 (ASTM 2000c). Figure 24 shows a typical British Pendulum test layout. The BP uses a weighted swing arm and rubber contact pad to determine what is called a British Pendulum Number (BPN). The orientation of the device and the height of the swing arm are controlled to provide a desired contact area for each test. The BPN is read directly from a scale ranging from 0 to 150 on the test equipment for each swing. The test is run until constant or nearly constant BPN values are obtained. The higher the number the greater the relative friction or skid resistance of the surface tested.

\section{Grip Tester}

The U.S. Air Force evaluated the skid resistance of each test section with a GripTester, Figure 25. The pavements surface effects team from Headquarters (HQ) Air Force Civil Engineer Support Agency from Tyndall AFB, Florida, 
conducted the testing. The Grip Tester is a three-wheeled trailer that measures a friction value by the braked wheel, fixed slip principle. Figure 26 shows a closeup of the Grip Tester device. A dynamic friction value is obtained by measuring the horizontal drag and vertical load forces from a smooth-tread tire mounted on the single measuring wheel.

Measurements of the skid resistance were taken at both 64.4 and $96.6 \mathrm{kmph}$ (40 and $60 \mathrm{mph}$ ). The test runs of the equipment were conducted by making passes in the same direction at each of the different speeds while driving down the middle of each test strip. The skid testing equipment takes all measurements on a wetted pavement. An onboard self-wetting system regulates water distribution to provide a $1-\mathrm{mm}(0.04-\mathrm{in}$.) film of water beneath the testing wheel at both test speeds. A water tank is part of the tow truck equipment and water is discharged in front of the skid wheel at a rate of about 10 or $15 \mathrm{gal} / \mathrm{min}$ at 40 or $60 \mathrm{mph}$, respectively. Mu values are continuously read and an onboard computer program lists the average value and vehicle speed every $15.2 \mathrm{~m}(50 \mathrm{ft})$.

The U.S. Air Force uses guidelines for Mu values developed by the Federal Aviation Administration (FAA). The FAA guidelines are given in Table 5.

\begin{tabular}{|c|c|c|}
\hline \multicolumn{3}{|c|}{$\begin{array}{l}\text { Table } 5 \\
\text { FAA Mu Value Guidelines for Wet Runway Surfaces }\end{array}$} \\
\hline \multirow[b]{2}{*}{ Friction Level Classification } & \multicolumn{2}{|c|}{$\begin{array}{c}\text { Grip Tester - Mu Result } \\
\end{array}$} \\
\hline & $64.4 \mathrm{kph}(40 \mathrm{mph})$ & $96.6 \mathrm{kph}(60 \mathrm{mph})$ \\
\hline Minimum & 0.43 & 0.24 \\
\hline Maintenance Planning & 0.53 & 0.36 \\
\hline
\end{tabular}

\section{Saab Friction Tester}

The skid resistance of the pavement sections at McGuire AFB were tested with a Saab Friction Tester (SFT) by the FAA's Airport Technology Research and Development Branch. The ASTM E 1551 test tire in the SFT was inflated to $206.8 \mathrm{kPa}$ (30 psi) (ASTM 2000d). A self-watering system was used for all tests. Test measurements were taken at both 64.4 and $96.6 \mathrm{kph}(40$ and $60 \mathrm{mph})$. The FAA noted in the tests results report that there was some variation in the water pressure gauge during testing.

\section{Material Costs}

A comparison or analysis of the cost of the materials used in this study was not conducted. The cost of using a product would be based on material, shipping, and application costs, and these would all be affected by the size (volume of material) of the project. The Fact Sheets (Appendix A) given on each product provide information that can be used for estimating the cost for a particular product in the time frame of this report. 


\section{WES Test Sections}

\section{Test Pavement}

Several rejuvenation and seal coat materials were analyzed in small test sections on pavement at the U.S. Army Engineer Research and Development Center (ERDC), Vicksburg, MS. These materials were placed by ERDC technicians. The purpose of these sections was to evaluate the fuel resistance of the nonpetroleum products and to provide further information regarding the texture and skid resistance tests. Considering the purpose of these sections, not all the materials were evaluated; those selected included the three petroleum-based rejuvenators and three coal-tar based rejuvenators. One seal coat material was also included to evaluate the manufacturer's claim that it was fuel resistant.

The mixtures were placed on part of an airfield pavement test section that had been in place for about 6 years. This pavement is in an area that experiences no traffic. Areas of $1.8 \mathrm{~m}^{2}\left(2 \mathrm{yd}^{2}\right)$ were laid out, and the materials were applied in the amounts given in Table 6 and shown in Figure 27. A schematic drawing of the test section is given in Figure 28. Unfortunately, Reclamite and GSB-mod, as noted in Table 6, were not properly diluted prior to application. All materials were applied by hand with a paintbrush. The amount applied was not predetermined but was based on the amount that the pavement appeared to readily absorb without leaving any excess or ponded material. The amount of material applied was later determined by knowing the mass of the material and the area over which it was applied.

\section{Surface Texture}

The sand patch test was used to determine the effect of each material on the surface texture of the pavement, Table 6 . The tests were conducted 2 to 4 days after placement of the material. The testing was conducted as discussed in the previous chapter, in accordance with E 965 (ASTM 2000b). The testing locations were located, as much as possible, in a single line, parallel to the direction of the paving that had been used to place the HMA. On three of the test areas, three separate tests were conducted and a Coefficient of Variation (COV) was determined for these tests. This alignment and a visual assurance that the pavement surfaces had a similar texture increased the probability of having the same or at least similar conditions at each test location. 


\begin{tabular}{|c|c|c|c|c|c|c|c|c|c|c|c|}
\hline \multicolumn{12}{|c|}{$\begin{array}{l}\text { Table } 6 \\
\text { Results of Tests on ERDC Field Test Sections }\end{array}$} \\
\hline \multirow[b]{3}{*}{ Material } & \multirow{3}{*}{$\begin{array}{l}\text { Rate of } \\
\text { Application, } \\
\mathrm{L} / \mathrm{m}^{2}\left(\mathrm{gal} / \mathrm{yd}^{2}\right)\end{array}$} & \multirow{2}{*}{\multicolumn{8}{|c|}{$\begin{array}{c}\text { Skid Number, BPN } \\
\text { Days after Placement } \\
\end{array}$}} & \multirow{3}{*}{$\begin{array}{l}\text { Fuel } \\
\text { Resistance }^{3}\end{array}$} & \multirow{3}{*}{$\begin{array}{l}\text { Sand Patch, } \\
\mathrm{mm} \text { (in.) }\end{array}$} \\
\hline & & & & & & & & & & & \\
\hline & & 1 & 2 & 4 & 8 & 53 & 107 & 364 & 375 & & \\
\hline RejuvaSeal N & $0.288(0.091)$ & 45 & 38 & 37 & 38 & 45 & 59 & 62 & 60 & Passed & $290.1(11.42)$ \\
\hline Reclamite $^{5}$ & $0.326(0.103)$ & 65 & 57 & 52 & 52 & 67 & 80 & 79 & 80 & --- & $295.3(11.63)$ \\
\hline LAS-320 & $0.184(0.058)$ & 42 & 37 & 37 & 36 & 50 & 42 & 47 & 46 & Passed $^{6}$ & $285.8(11.25)$ \\
\hline GSB-mod $^{7}$ & $0.424(0.134)$ & --- & 33 & 35 & 36 & 50 & 50 & 57 & 57 & --- & $313.7(12.35)$ \\
\hline APR-100 & $0.304(0.096)$ & --- & --- & --- & --- & $65-$ & 59 & 75 & 78 & --- & $\begin{array}{l}303.3^{8}(11.94), \\
2.18\end{array}$ \\
\hline BCR-2000 & $0.513(0.162)$ & --- & 35 & 56 & 64 & 67 & 42 & 52 & 52 & Passed & $\begin{array}{l}303.2^{8}(11.94), \\
2.74\end{array}$ \\
\hline CBRT-SO $^{9}$ & $0.288(0.091)$ & --- & --- & --- & --- & 45 & 44 & 53 & 52 & Passed & $\begin{array}{l}301.8^{8}(11.88), \\
0.80\end{array}$ \\
\hline \multicolumn{2}{|c|}{ Control 1 (Uncoated Surface) } & 85 & 80 & 79 & 80 & 93 & 81 & 77 & 80 & --- & $279.6(11.01)$ \\
\hline \multicolumn{2}{|c|}{ Control 2 (Uncoated Surface) } & 84 & 79 & 80 & 79 & $93^{7}$ & 84 & 79 & 82 & --- & $266.9^{9}(10.51)$ \\
\hline \multicolumn{12}{|c|}{ 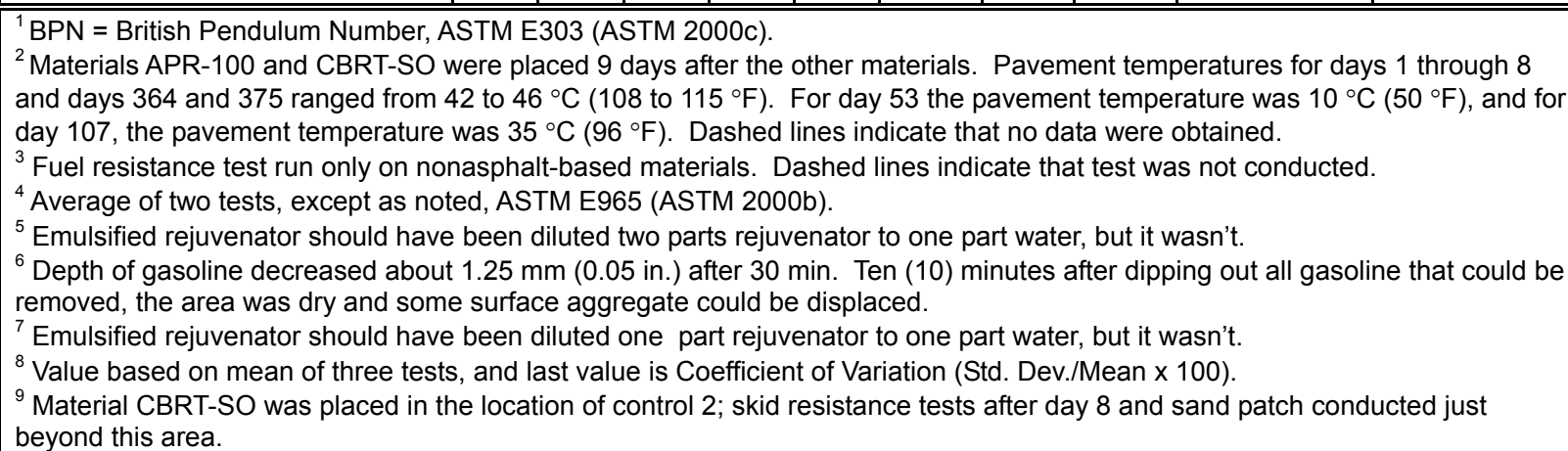 } \\
\hline
\end{tabular}

In order to evaluate the accuracy obtained with the sand patch test, three tests were performed in three of the test areas. The COV obtained from these three test areas are given in Table 6 . The low COV results obtained indicate that the tests were very repeatable and were indicative of the pavement in that area. The results from all tests fell within the acceptable range as defined in ASTM E 965 (ASTM 2000b).

\section{Skid Testing}

As was done on the field test sections at the two Air Force bases, a British Pendulum was used to determine the skid resistance in accordance with ASTM E 303 (ASTM 2000c). These tests were performed at a selected time interval following the application of the materials as given in Table 6 . The skid tests were run at the same location in each section containing one of the materials and in two control areas of the pavement. The location of the feet of the pendulum device was measured from an established reference to assure placement at the same location for each test. These testing locations were located in a single line 
parallel to the direction of paving that had been used to place the HMA. This alignment and a visual assurance that the pavement surfaces had the same texture were used to provide, as much as possible, similar surfaces for the tests on each material.

\section{Fuel Resistance}

Fuel resistance is generally only important when the pavement is in a parking, maintenance, or refueling area. Runways, taxiways, and roadways, except for accidents, are not normally exposed to petroleum (fuel) spills and therefore do not require a fuel-resistant surfacing. Coal-tar emulsion coatings are normally used to provide a fuel-resistant seal coat for pavements that require it.

Coal-tar materials, because they are not derived from petroleum, are fuel resistant. The coal-tar based materials, the sealer/rejuvenators, will provide a degree of fuel resistance because they tend to leave some residual material on the pavement surface. This residual material will provide a fuel-resistant surface; at least initially, the length of effectiveness will depend mainly on the amount of traffic the pavement receives. This coating could wear off within a relatively short time depending upon the level of traffic. Coal-tar seal coats will provide a fuel-resistant surface. Because of their generally greater thickness, they will last longer under traffic and will remain fuel resistant until they wear off or develop penetrable cracks. There are proprietary noncoal-tar sealer materials that are fuel resistant; however, cost and the lack of field experience have limited the use of these materials.

The standard fuel-resistance test for coal-tar sealer mixtures is defined in ASTM D 2939 (ASTM 2000e). The test method requires the application of the sealer to a prepared white tile and uses kerosene as the test fuel. This method can only evaluate fuel-resistance in the laboratory and is not directly applicable to thin spray applications. The Pavement Coating Technology Center (PCTC) has developed a field fuel-resistance test (Sebaaly et al. 1999). The rejuvenator and seal coat materials that are nonpetroleum based were evaluated for their fuel resistance using this test method. The test method requires applying a $150-\mathrm{mm}$ (6-in.)-diameter metal pipe to the pavement with a silicon sealant. Gasoline is then added to a depth of $25 \mathrm{~mm}$ ( $1 \mathrm{in}$.), and the penetration of the gasoline is evaluated through depth measurements at 15 and $30 \mathrm{~min}$. A lid is applied to the pipe to prevent excessive evaporation. For this study, a 150-mm (6-in.)-diameter PVC pipe was used for the ERDC field test sections, Figure 29. A sheet of Plexiglas was used as a lid for the tests. According to the established procedures, if the amount of gasoline loss is less than $0.5 \mathrm{~mm}(0.20 \mathrm{in}$.) in $30 \mathrm{~min}$, the material is considered fuel-resistant. Table 6 gives the results of testing on the rejuvenating and rejuvenator/sealer materials placed at ERDC. The procedure used to perform the fuel-resistance tests was adapted from the PCTC test method and is given in Appendix B (Sebaaly et al. 1999).

Fuel-resistance tests run on several uncoated HMA pavement surfaces revealed a problem or limitation that exists with the currently proposed test 
method. Most of the dense graded airfield HMA pavement sections tested did not fail the test, in fact only two of nine tests failed the existing test procedure, Tables 7 and 8. Data in Table 7, show that these two failed pavement sections

\begin{tabular}{|c|c|c|c|c|c|c|}
\hline \multicolumn{7}{|c|}{$\begin{array}{l}\text { Table } 7 \\
\text { Properties of Pavement Used for Fuel-Resistance Testing }\end{array}$} \\
\hline \multicolumn{2}{|c|}{ Pavement } & \multirow[b]{3}{*}{ Traffic } & \multirow{3}{*}{$\begin{array}{l}\text { Asphalt } \\
\text { Cement } \\
\text { Content, \% }\end{array}$} & \multicolumn{3}{|c|}{$\begin{array}{ll}\text { Air Void Content, \% } \\
\end{array}$} \\
\hline \multirow{2}{*}{$\begin{array}{l}\text { Test } \\
\text { Number }\end{array}$} & & & & \multirow[b]{2}{*}{ Laboratory } & \multicolumn{2}{|c|}{ Field (Trafficked) } \\
\hline & & & & & Before & After \\
\hline 1 & \multirow[t]{2}{*}{$\overline{\mathrm{A}}$} & $\begin{array}{l}\text { Yes } \\
\end{array}$ & \multirow[t]{2}{*}{$\overline{5.0}$} & \multirow[t]{2}{*}{2.3} & $\overline{--^{2}}$ & $\overline{c 1.6}$ \\
\hline 2 & & No & & & 5.7 & --- \\
\hline 3 & \multirow[t]{2}{*}{$\mathrm{B}$} & Yes & \multirow[t]{2}{*}{6.1} & \multirow[t]{2}{*}{3.2} & --- & 3.5 \\
\hline 4 & & No & & & 8.3 & --- \\
\hline 5 & \multirow[t]{3}{*}{$\mathrm{C}$} & \multirow[t]{3}{*}{ No } & \multirow[t]{3}{*}{4.7} & \multirow[t]{3}{*}{2.0} & \multirow[t]{3}{*}{6.6} & $-\ldots$ \\
\hline 6 & & & & & & $-\ldots$ \\
\hline 7 & & & & & & --- \\
\hline 8 & $\mathrm{D}$ & No & 4.2 & 4.4 & 9.5 & --- \\
\hline 9 & $\mathrm{E}$ & No & 4.9 & 2.4 & 7.5 & --- \\
\hline
\end{tabular}

\begin{tabular}{|c|c|c|c|c|c|c|c|c|}
\hline \multicolumn{9}{|c|}{$\begin{array}{l}\text { Table } 8 \\
\text { Results of Fuel-Resistance Testing on Uncoated HMA Pavement }\end{array}$} \\
\hline \multirow{2}{*}{$\begin{array}{l}\text { Test }^{1} \\
\text { Number }\end{array}$} & \multicolumn{8}{|c|}{ Total Loss of Gasoline Over Time In Minutes, mm (in.) } \\
\hline & 5 & 10 & 15 & 20 & 30 & 45 & 60 & 90 \\
\hline 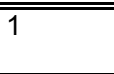 & $\begin{array}{c}0.5 \\
(0.02)\end{array}$ & $\begin{array}{l}1.5 \\
(0.06)\end{array}$ & $\begin{array}{l}2.0 \\
(0.08)\end{array}$ & $\begin{array}{l}2.3 \\
(0.09)\end{array}$ & $\begin{array}{l}2.8 \\
(0.11)\end{array}$ & $\begin{array}{l}3.0 \\
(0.12)\end{array}$ & $\begin{array}{c}4.1 \\
(0.16)\end{array}$ & $\begin{array}{c}4.6 \\
(0.18)\end{array}$ \\
\hline 2 & $\begin{array}{l}0.5 \\
(0.02)\end{array}$ & $\begin{array}{l}0.7 \\
(0.03)\end{array}$ & $\begin{array}{l}1.0 \\
(0.04)\end{array}$ & $\begin{array}{l}1.5 \\
(0.06)\end{array}$ & $\begin{array}{l}2.3 \\
(0.09)\end{array}$ & $\begin{array}{l}3.0 \\
(0.12)\end{array}$ & $\begin{array}{l}3.6 \\
(0.14)\end{array}$ & $\begin{array}{l}5.8 \\
(0.23)\end{array}$ \\
\hline 3 & $\begin{array}{c}0.5 \\
(0.02)\end{array}$ & $\begin{array}{l}1.3 \\
(0.05)\end{array}$ & $\begin{array}{l}1.3 \\
(0.05)\end{array}$ & $\begin{array}{l}2.3 \\
(0.09)\end{array}$ & $\begin{array}{c}2.5 \\
(0.1)\end{array}$ & $\begin{array}{c}3.3 \\
(0.13)\end{array}$ & $\begin{array}{c}3.8 \\
(0.15)\end{array}$ & $\begin{array}{c}4.6 \\
(0.18)\end{array}$ \\
\hline 4 & $\begin{array}{c}1.8 \\
(0.07) \\
\end{array}$ & $\begin{array}{c}2.3 \\
(0.09) \\
\end{array}$ & $\begin{array}{c}2.5 \\
(0.1) \\
\end{array}$ & $\begin{array}{c}3.3 \\
(0.13) \\
\end{array}$ & $\begin{array}{c}5.8^{2} \\
(0.23) \\
\end{array}$ & $\begin{array}{c}7.4^{3} \\
(0.29) \\
\end{array}$ & $--^{4}$ & $--^{4}$ \\
\hline 5 & $\begin{array}{c}0.5 \\
(0.02)\end{array}$ & $\begin{array}{c}0.5 \\
(0.02)\end{array}$ & $\begin{array}{c}0.7 \\
(0.03)\end{array}$ & $\begin{array}{l}1.3 \\
(0.05)\end{array}$ & $\begin{array}{c}1.5 \\
(0.06)\end{array}$ & $\begin{array}{c}2.5 \\
(0.1)\end{array}$ & $\begin{array}{l}2.8 \\
(0.11)\end{array}$ & $\begin{array}{c}4.6 \\
(0.18)\end{array}$ \\
\hline $6^{5}$ & $\begin{array}{l}0.3 \\
(0.01)\end{array}$ & $\begin{array}{c}0.7 \\
(0.03)\end{array}$ & $\begin{array}{l}1.5 \\
(0.06)\end{array}$ & $\begin{array}{l}1.5 \\
(0.06)\end{array}$ & $\begin{array}{l}1.8 \\
(0.07)\end{array}$ & $\begin{array}{l}2.3 \\
(0.09)\end{array}$ & $\begin{array}{l}2.5 \\
(0.1)\end{array}$ & $\begin{array}{l}3.0 \\
(0.12)\end{array}$ \\
\hline $7^{5}$ & $\begin{array}{l}0.3 \\
(0.01)\end{array}$ & $\begin{array}{l}0.5 \\
(0.02)\end{array}$ & $\begin{array}{c}0.5 \\
(0.02)\end{array}$ & $\begin{array}{c}0.7 \\
(0.03)\end{array}$ & $\begin{array}{l}0.7 \\
(0.03)\end{array}$ & $\begin{array}{l}1.3 \\
(0.05)\end{array}$ & $\begin{array}{c}1.5 \\
(0.06)\end{array}$ & $\begin{array}{c}1.5 \\
(0.06)\end{array}$ \\
\hline $8^{5}$ & $\begin{array}{l}1.0 \\
(0.04)\end{array}$ & $\begin{array}{l}1.5 \\
(0.06)\end{array}$ & $\begin{array}{l}2.0 \\
(0.08)\end{array}$ & $\begin{array}{l}2.3 \\
(0.09)\end{array}$ & $\begin{array}{l}7.4 \\
(0.29)^{6}\end{array}$ & $--^{4}$ & $--^{4}$ & $--^{4}$ \\
\hline 9 & $\begin{array}{c}0.7 \\
(0.03) \\
\end{array}$ & $\begin{array}{c}1.8 \\
(0.07) \\
\end{array}$ & $\begin{array}{c}2.3 \\
(0.09) \\
\end{array}$ & $\begin{array}{c}2.5 \\
(0.1) \\
\end{array}$ & $\begin{array}{l}2.8 \\
(0.11) \\
\end{array}$ & $\begin{array}{c}3.6 \\
(0.14) \\
\end{array}$ & $\begin{array}{c}4.8^{7} \\
(0.19) \\
\end{array}$ & $--^{4}$ \\
\hline \multicolumn{9}{|c|}{$\begin{array}{l}{ }^{1} \text { All tests used } 100-\mathrm{mm} \text { (4-in.)-diam. pipe unless marked otherwise. } \\
2 \text { Test specimen failed. } \\
{ }^{3} \text { Reading at } 35 \text { min, test stopped after this reading. } \\
{ }^{4} \text { Dashed lines indicate that no data were obtained. } \\
{ }^{5} \text { Used } 150-\mathrm{mm} \text { (6-in.)-diam. pipe. } \\
{ }^{6} \text { Test stopped after } 30 \text { min, fuel leaking through to outside of pipe. } \\
{ }^{7} \text { Test stopped for leakage through crack to outside of pipe. }\end{array}$} \\
\hline
\end{tabular}

had the highest in-place air voids. Several of the uncoated HMA pavement surfaces took in excess of $4 \mathrm{hr}$ to fail the test. Tests were run using either 100-mm (4-in.) or 150-mm (6-in.)-diam. PVC pipes. A comparison of results on the same type of pavement indicated that the diameter of the pipe did not appear to affect the overall results. During these tests, the gasoline did quickly discolor, 
and immediately after failure, the surface aggregate within the pipe was easily dislodged. When running the testing on fuel-resistant surfaces, the fuel didn't readily discolor, and the surface materials were not loosened. Therefore, the test procedure should be changed to require visual inspection of any color change of the gasoline and inspection for damage to the pavement surface at the conclusion of the time limit (30 min) given for the test.

\section{Summary}

The results of the surface texture testing (Table 6) showed that, as expected, the addition of a material to the pavement surface reduced the surface voids. The results obtained between two separate untreated areas (controls 1 and 2) showed an apparently significant difference, considering that the test locations were selected for similar surface texture and in the same longitudinal plane within the same paving lane. However, additional testing conducted within three of the treated test areas had a low variation between test results as evidenced by their low COV values.

The results of the BP (skid resistance) testing (Table 6) showed that relatively consistent results could be obtained when the tests were performed at the same location each time. The test results showed an apparent effect from a change in pavement temperature. The operating instructions supplied with the Wessex Skid Tester (British Pendulum) stated that temperature, $10^{\circ} \mathrm{C}$ and below, could have a substantial effect.

The results of the fuel-resistance (gasoline) testing (Table 7) on the nonpetroleum materials showed that they all passed the test. Test results on various dense graded airfield HMA mixtures (Table 8) showed that the gasoline test procedure as it currently exists is not adequate for asphalt pavements with relatively low asphalt contents and high density. Their permeability appears to be so low that the fuel doesn't drain fast enough to fail the test within the given time frame. Although it doesn't fail within the given time, the pavement surface is sufficiently softened to allow the surface aggregate to be easily dislodged. An evaluation of the color change in the gasoline and an evaluation of the integrity of the pavement surface after the 30-min test time would provide the information required to adequately judge the fuel resistance of a pavement surface. 


\section{Laboratory Evaluation}

\section{Material Properties}

The laboratory evaluation of the rejuvenator and seal coat materials began with a general examination of their material properties relative to their composition. Based upon the general makeup of the material, such as whether it was an emulsion or a solvent, the properties of the various materials varied. The intent was not to discover the components of the material but to obtain information on physical properties including viscosity, water content (emulsions), flash point (solvent based), and percentage of residual material.

\section{Field Test Section Samples}

The most important feature of a rejuvenator material is its effect on the properties of the asphalt cement binder in the pavement. The HMA in the field test sections at both MacDill and McGuire AFBs was evaluated both visually and through test methods as described in Chapter 3. Core samples were also taken from each of the sections for evaluation of the properties of the asphalt cement. Samples were taken before the application of any of the materials and again approximately 1 month and 1 year after placement of the materials. The minimum time of about 1 month prior to coring allowed for any excess volatile materials to evaporate and allowed for the rejuvenation effects from the materials to occur. The samples taken consisted of 150-mm (6-in.)-diam. cores. These were not taken randomly within the particular section but were grouped in a representative area that contained minimal cracking or other surface distresses that would adversely affect the suitability of the core.

The rejuvenator/sealer materials in relation to the rejuvenator materials produced a coating or sealing on the surface of the pavement. To investigate the effect of this coating on their overall rejuvenation performance, the top $1 \mathrm{~mm}$ (0.04 in.) of several of these rejuvenator and rejuvenator/sealer materials was removed and the results compared to core specimens without the coating removed (Figure 30). The top coating and the part of the core specimens to be used for extraction of the asphalt cement were cut with a concrete table saw, (Figure 31). The thickness of the cut sections of the cores to be extracted was approximately $10 \mathrm{~mm}(0.4 \mathrm{in}$.) or $9 \mathrm{~mm}(0.36 \mathrm{in}$.) when the top $1 \mathrm{~mm}(0.04 \mathrm{in}$.) was removed. Tables 9, 10, and 11 list the mean and the COV of the 


\begin{tabular}{|c|c|c|c|c|c|c|}
\hline \multicolumn{7}{|c|}{$\begin{array}{l}\text { Table } 9 \\
\text { Preparation of Field Cores from TW O at MacDill AFB }{ }^{1}\end{array}$} \\
\hline \multirow[b]{2}{*}{ Material } & \multirow[b]{2}{*}{ Area $^{2}$} & \multirow[b]{2}{*}{ Section $^{2}$} & \multicolumn{2}{|c|}{$\begin{array}{c}\text { Thickness Removed }^{3} \\
\left(2000^{3} / 2001\right)\end{array}$} & \multicolumn{2}{|c|}{$\begin{array}{c}\text { Thickness Extracted }{ }^{3} \\
\left(2000^{3} / 2001\right)\end{array}$} \\
\hline & & & Mean, mm (in.) & $\operatorname{cov}^{4}$ & Mean, mm (in.) & $\mathrm{COV}^{4}$ \\
\hline \multirow[t]{3}{*}{ BCR-2000 } & \multirow[t]{6}{*}{ 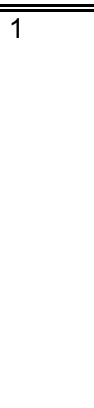 } & \multirow[t]{2}{*}{$\bar{A}$} & $\begin{array}{l}1.020(0.0402) / \\
1.549(0.061)\end{array}$ & $\begin{array}{l}17.0 / \\
7.48\end{array}$ & $\begin{array}{c}10.39(0.409) / \\
8.56(0.337)\end{array}$ & $\begin{array}{l}1.31 / \\
1.82\end{array}$ \\
\hline & & & --- & --- & $\begin{array}{l}10.89(0.429) / \\
10.03(0.395)\end{array}$ & $\begin{array}{l}4.06 / \\
5.24\end{array}$ \\
\hline & & \multirow[t]{2}{*}{$\bar{C}$} & $\begin{array}{l}1.161(0.0457) / \\
---\end{array}$ & $\begin{array}{l}14.4 / \\
---\end{array}$ & $10.55(0.415) /$ & $1.46 /$ \\
\hline BCR-3000 & & & --- & --- & $\begin{array}{l}10.01(0.394) / \\
--\end{array}$ & $\begin{array}{l}3.55 / \\
---\end{array}$ \\
\hline \multirow[t]{2}{*}{ Uncoated } & & \multirow[t]{2}{*}{---} & $\begin{array}{l}---/ \\
1.392(0.0548)\end{array}$ & ---1 & $\begin{array}{l}---/ \\
8.56(0.337)\end{array}$ & $\begin{array}{l}---/ \\
4.54\end{array}$ \\
\hline & & & --- & $\begin{array}{l}-- \\
-\end{array}$ & $9.30(0.366)$ & $\begin{array}{l}---/ \\
1.93\end{array}$ \\
\hline RejuvaSeal 50 & \multirow[t]{3}{*}{2} & A & --- & --- & $\begin{array}{c}10.22(0.402) / \\
8.43(0.332) \\
\end{array}$ & $\begin{array}{l}1.46 / \\
9.91\end{array}$ \\
\hline \multirow[t]{2}{*}{ RejuvaSeal N } & & \multirow[t]{2}{*}{$\mathrm{C}$} & $\begin{array}{l}--/ \\
1.123(0.0442)\end{array}$ & $\begin{array}{ll}--1 \\
9.95 \\
\end{array}$ & $\begin{array}{l}---/ \\
7.79(0.307)\end{array}$ & 8.12 \\
\hline & & & -- & --- & $\begin{array}{c}10.18(0.401) / \\
8.99(0.354) \\
\end{array}$ & $\begin{array}{l}2.16 / \\
1.05 \\
\end{array}$ \\
\hline \multirow[t]{3}{*}{ Reclamite } & \multirow[t]{3}{*}{3} & \multirow[t]{2}{*}{$\bar{A}$} & $\begin{array}{l}1.295(0.0510) / \\
1.27(0.050) \\
\end{array}$ & $\begin{array}{l}7.44 / \\
14.9 \\
\end{array}$ & $\begin{array}{c}10.55(0.416) / \\
7.04(0.277) \\
\end{array}$ & $\begin{array}{l}1.96 / \\
3.02 \\
\end{array}$ \\
\hline & & & --- & --- & $\begin{array}{c}10.21(0.402) / \\
8.71(0.343) \\
\end{array}$ & $\begin{array}{l}1.87 / \\
4.90 \\
\end{array}$ \\
\hline & & $\mathrm{C}$ & --- & --- & $\begin{array}{l}9.86(0.388) / \\
9.37(0.369)\end{array}$ & $\begin{array}{l}2.73 / \\
2.90\end{array}$ \\
\hline \multirow[t]{2}{*}{ GSB-mod } & \multirow[t]{2}{*}{4} & \multirow[t]{2}{*}{ A } & $\begin{array}{l}0.914(0.0360) / \\
1.23(0.0485) \\
\end{array}$ & $\begin{array}{l}20.0 / \\
7.69 \\
\end{array}$ & $\begin{array}{c}10.33(0.407) / \\
8.18(0.322) \\
\end{array}$ & $\begin{array}{l}2.80 / \\
3.20 \\
\end{array}$ \\
\hline & & & --- & --- & $\begin{array}{l}10.11(0.398) / \\
10.46(0.412) \\
\end{array}$ & \begin{tabular}{|l|}
$3.73 /$ \\
3.03 \\
\end{tabular} \\
\hline \multicolumn{7}{|c|}{$\begin{array}{l}{ }^{1} \text { Cores cut and asphalt extracted between } 6 \text { and } 8 \text { weeks after placement. Dashed lines indicate } \\
\text { that values are either undefined or data not obtained. } \\
{ }^{2} \text { Detailed in Figure } 6 \text {. Dashed line indicates that sample was taken in Area 1, but not within treated } \\
\text { area. } \\
{ }^{3} \text { Values reported are based on six sets of measurements (two halves of three cores), unless stated } \\
\text { otherwise. } \\
{ }^{4} \mathrm{COV}=\text { std. dev./ mean } \times 100 .\end{array}$} \\
\hline
\end{tabular}

thicknesses of the cores that were used for extraction. Obtaining samples of the asphalt cement from the top $9 \mathrm{~mm}(3 / 8 \mathrm{in}$.) and, in some cases, removing the top $1 \mathrm{~mm}(0.04 \mathrm{in}$.) of the pavement cores was difficult to do consistently, as evidenced by the occasional high COV values obtained in Tables 9 through 11 .

To obtain enough recovered asphalt cement for the tests described below, the HMA from three cores was combined for each test specimen. The extraction and recovery were performed in accordance with ASTM D 2172 and D 1856, respectively (ASTM 2000f and ASTM 2000g). This required a total of six cores from sections where the properties with and without the top surface were to be evaluated. An additional core was obtained for each nonpetroleum material for later evaluation of fuel resistance. 


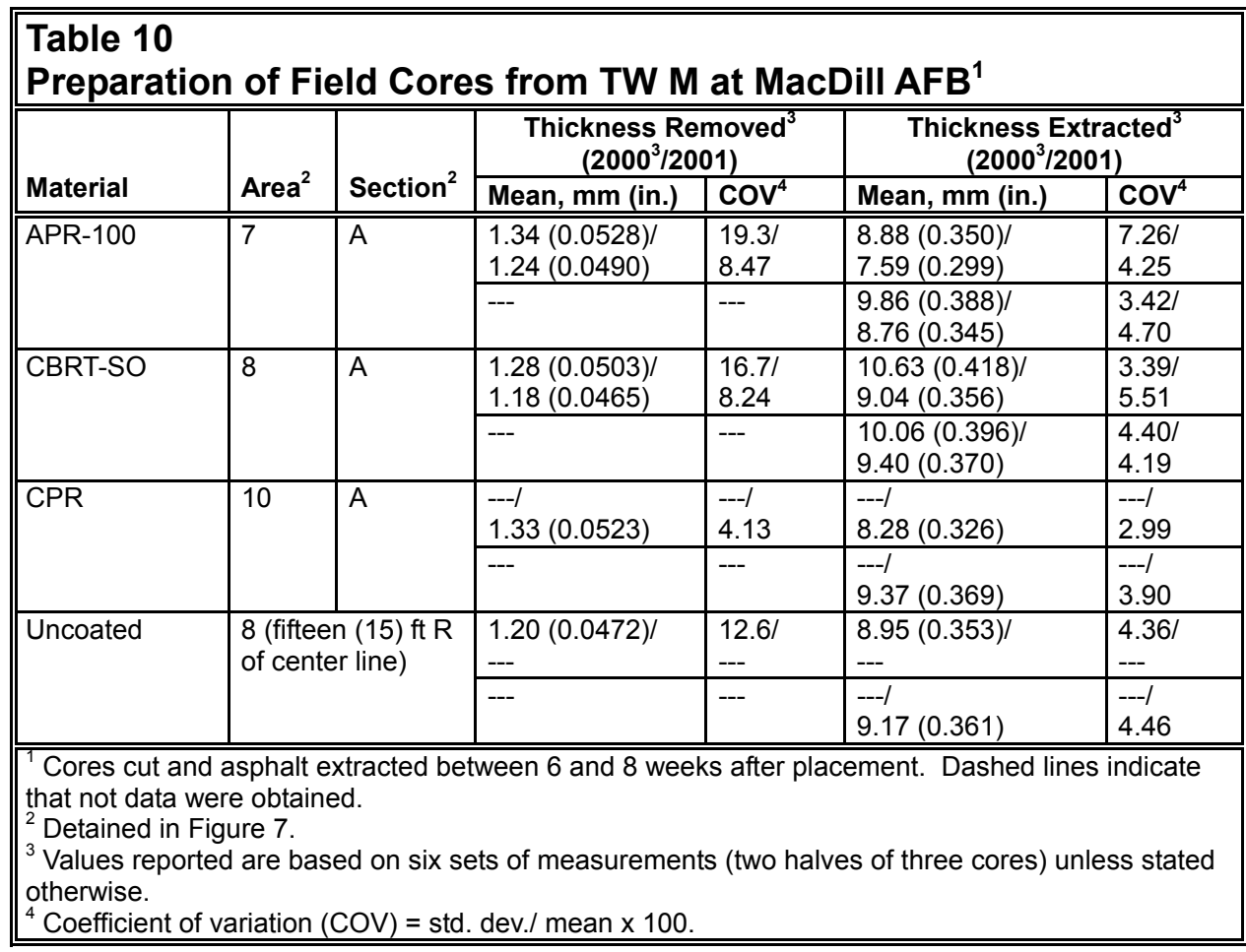

\section{Penetration and viscosity}

The penetration and kinematic viscosity values were obtained according to ASTM D 5 and D 2170, respectively (ASTM 2000h and ASTM 2000i). Previous research has shown that when compared to penetration, viscosity is the better method to show the effect of rejuvenators on asphalt cement (Brown and Johnson 1976). Kinematic viscosity was selected as the comparison viscosity method at a temperature of $135^{\circ} \mathrm{C}\left(275^{\circ} \mathrm{F}\right)$ because of the age and hardness of the original prerejuvenated asphalt cement.

\section{Dynamic shear rheometer}

DSR testing was performed on the recovered asphalt samples, according to P 246 (ASTM 2000j). The DSR parameters, phase angle ( $\delta$ ) and complex modulus $\left(\mathrm{G}^{*}\right)$, were obtained at $60^{\circ} \mathrm{C}\left(140^{\circ} \mathrm{F}\right)$. A total of four or five individual tests were run on each sample, and the $\mathrm{COV}$ values for these results were determined.

\section{Fuel Resistance}

The fuel resistance of each rejuvenator/sealer and seal coat material not composed mainly of petroleum was evaluated by exposing the treated surface to gasoline. The test method used was similar to that detailed previously with the 


\begin{tabular}{|c|c|c|c|c|c|c|}
\hline \multicolumn{7}{|c|}{$\begin{array}{l}\text { Table } 11 \\
\text { Preparation of Field Cores from TW L at McGuire AFB }{ }^{1}\end{array}$} \\
\hline \multirow[t]{2}{*}{ (1) } & \multirow[b]{2}{*}{ Area } & \multirow[b]{2}{*}{ Section } & \multicolumn{2}{|c|}{$\begin{array}{c}\text { Thickness Removed } \\
(2000 / 2001)^{2}\end{array}$} & \multicolumn{2}{|c|}{$\begin{array}{c}\text { Thickness Extracted } \\
(2000 / 2001)^{2} \\
\end{array}$} \\
\hline & & & Mean, mm (in.) & $\mathrm{COV}^{3}$ & Mean, mm (in.) & $\mathrm{COV}^{3}$ \\
\hline \multirow[t]{3}{*}{ GSB-mod } & \multirow[t]{3}{*}{ 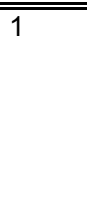 } & $\overline{\mathrm{C}}$ & (--- & ("-- & $10.69(0.421) /$ & $\begin{array}{c}2.071 \\
--\end{array}$ \\
\hline & & $\mathrm{D}$ & $\begin{array}{l}0.975(0.0384) / \\
0.762(0.03)\end{array}$ & $\begin{array}{l}14.2 / \\
18.9\end{array}$ & $\begin{array}{l}9.39(0.370) / \\
9.55(0.376)\end{array}$ & $\begin{array}{l}3.70 / \\
17.8\end{array}$ \\
\hline & & & --- & --- & $\begin{array}{l}10.69(0.421) / \\
10.52(0.414)\end{array}$ & $\begin{array}{l}2.34 / \\
4.61\end{array}$ \\
\hline \multirow[t]{4}{*}{ RejuvaSeal N } & \multirow[t]{6}{*}{2} & $\mathrm{~B}$ & $\begin{array}{l}0.503(0.0198) / \\
1.27(0.05)\end{array}$ & $\begin{array}{l}50.1 / \\
13.6\end{array}$ & $\begin{array}{l}8.50(0.335) / \\
9.65(0.380)\end{array}$ & $\begin{array}{l}5.60 / \\
9.03\end{array}$ \\
\hline & & & --- & --- & $\begin{array}{l}10.86(0.428) / \\
10.33(0.407)\end{array}$ & $\begin{array}{l}2.25 / \\
5.17\end{array}$ \\
\hline & & $\mathrm{F}$ & $\begin{array}{l}0.693(0.0273) / \\
---\end{array}$ & $\begin{array}{l}37.4 / \\
---\end{array}$ & $8.23(0.324) /$ & $5.00 /$ \\
\hline & & & --- & --- & $11.27(0.444) /$ & $\begin{array}{l}4.21 / \\
---\end{array}$ \\
\hline \multirow[t]{2}{*}{ BCR-2000 } & & $\mathrm{C}$ & --- & --- & $\begin{array}{c}10.62(0.418) / \\
8.86(0.349)\end{array}$ & $\begin{array}{l}3.86 / \\
3.38\end{array}$ \\
\hline & & $E$ & --- & --- & $10.76(0.424) /$ & $\begin{array}{l}7.81 / \\
---\end{array}$ \\
\hline \multirow[t]{4}{*}{ Reclamite } & \multirow[t]{4}{*}{3} & \multirow[t]{3}{*}{$A$} & $\begin{array}{l}0.528(0.0208) / \\
1.328(0.0523) \\
\end{array}$ & $\begin{array}{l}21.2 / \\
23.9 \\
\end{array}$ & $\begin{array}{l}8.47(0.333) / \\
8.79(0.346) \\
\end{array}$ & $\begin{array}{l}4.63 / \\
4.86 \\
\end{array}$ \\
\hline & & & -- & --- & $11.50(0.453) /$ & $\begin{array}{l}2.75 / \\
---\end{array}$ \\
\hline & & & $\begin{array}{l}--/ \\
0.851(0.0335)\end{array}$ & $\begin{array}{l}--/ \\
15.2\end{array}$ & $\begin{array}{l}---/ \\
8.86(0.349)\end{array}$ & $\begin{array}{l}---/ \\
6.30\end{array}$ \\
\hline & & $\mathrm{D}$ & -- & --- & $11.39(0.448) /$ & $\begin{array}{l}2.39 / \\
---\end{array}$ \\
\hline \multirow[t]{2}{*}{ CBRT-SO } & \multirow[t]{4}{*}{4} & \multirow[t]{2}{*}{$B$} & $\begin{array}{l}1.433(0.0564) / \\
1.27(0.050)\end{array}$ & $\begin{array}{l}26.1 / \\
12.5\end{array}$ & $\begin{array}{l}8.58(0.338) / \\
9.78(0.385)\end{array}$ & $\begin{array}{l}4.30 / \\
5.87\end{array}$ \\
\hline & & & --- & --- & $\begin{array}{c}11.36(0.447) / \\
9.75(0.384)\end{array}$ & $\begin{array}{l}3.16 / \\
5.31\end{array}$ \\
\hline \multirow[t]{2}{*}{ CPR } & & \multirow[t]{2}{*}{$\bar{E}$} & $\begin{array}{l}---/ \\
1.237(0.0487)\end{array}$ & $\begin{array}{l}---1 \\
16.7 \\
\end{array}$ & $\begin{array}{l}---1 \\
9.17(0.361)\end{array}$ & $\begin{array}{l}---/ \\
2.46 \\
\end{array}$ \\
\hline & & & & & $\begin{array}{l}---1 \\
9.50(0.374)\end{array}$ & $\begin{array}{l}---/ \\
4.30\end{array}$ \\
\hline RejuvaSeal 500 & \multirow[t]{5}{*}{5} & $A$ & --- & --- & $\begin{array}{l}11.64(0.458) / \\
10.26(0.404)\end{array}$ & $\begin{array}{l}6.26 / \\
10.6\end{array}$ \\
\hline BCR-3000 & & $\mathrm{B}$ & --- & --- & $11.38(0.448) /$ & $\begin{array}{l}3.34 / \\
---\end{array}$ \\
\hline \multirow[t]{3}{*}{ AR-2000 } & & \multirow[t]{2}{*}{ C } & $\begin{array}{l}0.909(0.0358) / \\
0.818(0.0322)\end{array}$ & $\begin{array}{l}13.9 / \\
12.8\end{array}$ & $\begin{array}{l}9.43(0.371) / \\
9.02(0.355)\end{array}$ & $\begin{array}{l}3.721 \\
4.56\end{array}$ \\
\hline & & & --- & --- & $\begin{array}{c}11.81(0.465) / \\
9.73(0.383)\end{array}$ & $\begin{array}{l}2.42 / \\
3.99\end{array}$ \\
\hline & & $\mathrm{D}$ & --- & --- & $11.45(0.451) /$ & $\begin{array}{l}4.12 / \\
---\end{array}$ \\
\hline \multirow[t]{2}{*}{ APR-100 } & \multirow[t]{2}{*}{6} & \multirow[t]{2}{*}{$B$} & $\begin{array}{l}0.528(0.0208) / \\
0.859(0.0338)\end{array}$ & $\begin{array}{l}7.12 / \\
12.9\end{array}$ & $\begin{array}{l}9.14(0.360) / \\
8.69(0.342)\end{array}$ & $\begin{array}{l}8.43 / \\
2.95\end{array}$ \\
\hline & & & -- & --- & $\begin{array}{c}11.65(0.459) / \\
9.61(0.379)\end{array}$ & $\begin{array}{l}3.83 / \\
2.77\end{array}$ \\
\hline \multirow[t]{3}{*}{ Uncoated } & 2 & --- & $\begin{array}{l}1.135(0.0447) / \\
---\end{array}$ & $\begin{array}{l}19.1 / \\
---\end{array}$ & $\begin{array}{l}9.21(0.363) / \\
9.33(0.368)\end{array}$ & $\begin{array}{l}5.72 / \\
5.09\end{array}$ \\
\hline & \multirow[t]{2}{*}{3} & \multirow[t]{2}{*}{---} & $\begin{array}{l}0.846(0.0333) / \\
1.174(0.0462)\end{array}$ & $\begin{array}{l}17.9 / \\
17.8\end{array}$ & $\begin{array}{l}9.06(0.357) / \\
9.04(0.356)\end{array}$ & $\begin{array}{l}7.66 / \\
8.90\end{array}$ \\
\hline & & & & & $\begin{array}{l}---/ \\
10.19(0.401)\end{array}$ & ---1 \\
\hline \multicolumn{7}{|c|}{$\begin{array}{l}{ }^{1} \text { Values reported are based on } 6 \text { sets of measurements ( } 2 \text { halves of } 3 \text { cores), unless stated } \\
\text { otherwise. } \\
{ }^{2} \text { Cores cut and asphalt extracted between } 6 \text { and } 8 \text { weeks after placement. } \\
{ }^{3} \text { Coefficient of variation }(\mathrm{COV})=\text { std dev./ mean } \times 100 \text {. Dashed lines indicate no data. }\end{array}$} \\
\hline
\end{tabular}


evaluation of the ERDC test sections (Sebaaly et al. 1999). In the laboratory, a 100-mm (4-in.)-diam PVC pipe was used for testing on 150-mm (6-in.)-diam cores obtained from test sections at the air force bases. Except for the use of 100-mm (4-in.)-diam PVC pipe, the materials and procedures were identical to those used in the field evaluation.

\section{Artificially Aged-Rejuvenated Asphalt}

The relative effectiveness of several rejuvenator materials was evaluated by aging an asphalt cement and then combining it with a rejuvenating material. The asphalt cement used was an AC-20 asphalt cement (ASTM 2000k). The asphalt cement also met the requirements of a PG 64-28, according to D 6373 (ASTM 20001). The various asphalt cement test mixtures were aged in the pressure-aging vessel (PAV), according to D 6521 (ASTM 2000m). The effectiveness of the rejuvenator materials was evaluated by determining the material property parameters of each test mixture through the use of the dynamic shear rheometer (DSR), according to P 246 (ASTM 2000j).

A total of five rejuvenator materials were selected for this investigation. The rejuvenators selected consisted of three asphalt-based and two coal-tar based materials, Table 12. Rejuvenation of the aged asphalt cement involved mixing the desired amount of rejuvenator into samples of the aged asphalt cement. Test samples were developed by taking some of the aged asphalt cement and heating it until it was sufficiently fluid and then each rejuvenator was slowly blended by hand mixing at the rates given in Table 12. Ten different blends of rejuvenated aged asphalt were initially developed by adding each of the five selected rejuvenating materials at the two application rates, Table 12.

\begin{tabular}{|c|c|c|}
\hline $\begin{array}{l}\text { Table } 12 \\
\text { Rejuvenator Amounts for }\end{array}$ & Given Additive Ra & \\
\hline & Ratio by Weight of & or to Asphalt Binder \\
\hline Material & $0.158 \mathrm{~L} / \mathrm{m}^{2}$ (0.05 gsy) & $0.316 \mathrm{~L} / \mathrm{m}^{2}(0.10 \mathrm{gsy})$ \\
\hline Reclamite, ${ }^{1}$ APR-100, and GSB-mod ${ }^{2}$ & 0.297 to 1 & 0.594 to 1 \\
\hline BCR-2000 and RejuvaSeal N & 0.309 to 1 & 0.618 to 1 \\
\hline
\end{tabular}

The samples were evaluated using the standard DSR temperature regimen for this grade of asphalt (PG 64-28). DSR tests were conducted on asphalt cements containing $0.158 \mathrm{~L} / \mathrm{m}^{2}(0.05 \mathrm{gsy})$ and $0.316 \mathrm{~L} / \mathrm{m}^{2}(0.10 \mathrm{gsy})$ of the various rejuvenator materials, after aging with one PAV cycle. After the completion of the DSR evaluation, the aged asphalt of all 10 rejuvenated blends of asphalt was run through the PAV for a second aging. These samples were then evaluated with a final DSR testing of the rejuvenated asphalt cements. 
The DSR parameters, phase angle $(\delta)$ and complex modulus $\left(\mathrm{G}^{*}\right)$, were obtained over the range of temperatures given in D 6373 (ASTM 20001). The values of the phase angle and the dynamic modulus were used to calculate the dynamic shear $\left(\mathrm{G}^{*} \sin \delta\right)$ value for each mixture at the selected temperatures.

\section{Seal Coat Cohesive/Adhesive Properties}

A seal coat placed on an airfield pavement needs to have sufficient cohesive and/or adhesive strength to allow it to withstand high-tire-pressure traffic. The strength values can be measured with a pulloff strength test using an Elcometer device. This device is defined in D 4541 as a fixed-alignment adhesion tester (ASTM 2000n). The test involves epoxying a 20- or 40-mm (0.785- or 1.57-in.)diam dolly (aluminum test plug) to the surface to be tested. The pulloff strength is obtained by determining the greatest perpendicular force (in tension) that can be exerted on surface of a plug. Failure types can be classified as either cohesive (within the sealer itself) or adhesive (pulling the sealer intact from the surface). Therefore, an adhesive failure indicates that the tensile strength of the sealer exceeded the tensile or cohesive strength of the underlying HMA.

The strength values obtained represent the maximum tensile strength of the sealers at the temperature at the time of the test. The strength values of asphalt cement in the HMA pavement and the various binders in the seal coat materials are all affected by changes in temperature. Generally, the strength values of these binder materials increase with a decrease in temperature. The rate of change of strength with temperature is not constant between the various binders, and it also changes as these materials age. However, test results can usually be used for comparative purposes if they are performed at approximately the same temperature. 


\section{Results}

\section{Field Results}

\section{Surface texture results - sand patch}

Several rejuvenator manufacturers recommend applying sand to the treated surface. At MacDill AFB the benefit of this sand application was evidenced by the smaller diameter (greater texture) achieved with the sand patch test on sanded versus the nonsanded sections, Tables 13 and 14. The tests performed on uncoated areas showed a wide variation in the results obtained throughout the taxiway pavements. These variations in values prevented the sand patch test results from having a close correlation to the skid resistance obtained for the pavement. The same general trend occurred at McGuire AFB, Table 15.

\section{Skid resistance results}

The skid resistance results obtained from the Grip Tester were more consistent than with the BP. This was not completely unexpected, considering that one BP test evaluates an area of pavement equal to about $9,375 \mathrm{~mm}^{2}\left(14.5\right.$ in. $\left.^{2}\right)$; while, one Grip Tester test value is the average of the values obtained over a $15.2-\mathrm{m}(50-\mathrm{ft})$ length, and five to seven of these values are averaged over the length of each section tested.

\section{British Pendulum}

The BPN values obtained at both U.S. Air Force bases showed, through higher values, the benefit derived from applying sand to the surface after material application, Tables 16, 17, and 18. The BPN values are given in bold type in these tables. Evaluation at both bases in the uncoated areas showed considerable variation in BPN values. Therefore, except for general trends, the results of BP tests taken at various locations throughout the test area on the taxiways could not readily determine the effect of an individual material on the skid resistance of the pavement. 


\begin{tabular}{|c|c|c|c|c|}
\hline \multicolumn{5}{|c|}{$\begin{array}{l}\text { Table } 13 \\
\text { Results of Pavement Texture Tests on TW O at MacDill AFB }\end{array}$} \\
\hline \multirow[b]{2}{*}{ Material } & \multirow[b]{2}{*}{ Area $^{1}$} & \multirow[b]{2}{*}{ Section $^{1}$} & \multicolumn{2}{|c|}{$\begin{array}{ll}\text { Sand Patch } & \text {, Diameter, } \mathrm{mm} \text { (in.) } \\
\end{array}$} \\
\hline & & & August 2000 & August 2001 \\
\hline \multirow[t]{2}{*}{ BCR-2000 } & \multirow[t]{3}{*}{1} & A & $\begin{array}{l}287.3(11.31) \\
287.3(11.31) \\
\end{array}$ & $\begin{array}{l}290.6(11.44) \\
295.7(11.64) \\
\end{array}$ \\
\hline & & $\mathrm{B}$ & $300.8(11.84)$ & $\begin{array}{l}315.5(12.42) \\
302.4(11.91)\end{array}$ \\
\hline BCR-3000 & & $\mathrm{C}$ & $\begin{array}{l}242.4(9.55) / 7.28^{3} \\
284.2(11.19) \\
294.6(11.60)\end{array}$ & $\begin{array}{l}271.1(10.67) \\
251.2(9.89)\end{array}$ \\
\hline RejuvaSeal 50 & \multirow[t]{3}{*}{2} & A & $\begin{array}{l}264.7(10.42) / 5.37^{3} \\
301.6(11.88) \\
301.6(11.88)\end{array}$ & $\begin{array}{l}262.3(10.33) \\
240.1(9.45)\end{array}$ \\
\hline \multirow[t]{2}{*}{ RejuvaSeal N } & & $\mathrm{B}$ & --- & $258.0(10.16)$ \\
\hline & & $\mathrm{C}$ & $312.1(12.29)$ & $\begin{array}{l}293.7(11.56)^{4} \\
328.6(12.94) \\
\end{array}$ \\
\hline \multirow[t]{3}{*}{ Reclamite } & \multirow[t]{4}{*}{3} & A & $\begin{array}{l}291.3(11.47) \\
277.9(10.94)\end{array}$ & $\begin{array}{l}261.9(10.31)^{4} \\
287.3(11.31)\end{array}$ \\
\hline & & $\mathrm{B}$ & --- & --- \\
\hline & & $\mathrm{C}$ & $\begin{array}{l}262.1(10.32) / 1.93^{3} \\
234.2(9.22) \\
238.9(9.41)\end{array}$ & $\begin{array}{l}279.0(10.98)^{4} \\
260.0(10.23)\end{array}$ \\
\hline Antiskid & & $\mathrm{D}$ & --- & $\begin{array}{l}156.1(6.15)[2.77]^{4,5} \\
175.0(6.89)\end{array}$ \\
\hline \multirow[t]{3}{*}{ GSB-mod } & \multirow[t]{3}{*}{4} & A & $\begin{array}{l}254.3(10.01) / 1.67^{3} \\
254.8(10.03) \\
256.4(10.09)\end{array}$ & $255.6(10.06)$ \\
\hline & & $\mathrm{B}$ & --- & $294.9(11.61)$ \\
\hline & & $\mathrm{C}$ & $319.1(12.56)$ & $\begin{array}{l}281.8(11.09)^{4} \\
346.1(13.63)\end{array}$ \\
\hline \multirow[t]{12}{*}{ Uncoated } & \multicolumn{2}{|c|}{ Above $2 \mathrm{~A}$} & --- & $280.6(11.05)^{4}$ \\
\hline & \multicolumn{2}{|c|}{ Between center line \& 2A } & $251.6(9.91)$ & --- \\
\hline & \multicolumn{2}{|c|}{ Between 2A and 2B } & $273.1(10.75)$ & $\overline{---}$ \\
\hline & \multicolumn{2}{|c|}{ Between 2B and 2C } & $\begin{array}{l}257.2(10.13) \\
282.6(11.13) \\
\end{array}$ & --- \\
\hline & \multicolumn{2}{|c|}{ Right of 2C } & $266.7(10.5)$ & --- \\
\hline & \multicolumn{2}{|c|}{ Between 1A \& 3A } & $279.4(11.00)$ & $\begin{array}{l}279.0(10.98) \\
270.7(10.66)\end{array}$ \\
\hline & \multicolumn{2}{|c|}{ Between 1B \& 3B } & --- & $\begin{array}{l}269.1(10.59) \\
272.7(10.73) \\
\end{array}$ \\
\hline & \multicolumn{2}{|c|}{ Between 1C \& 3C } & $273.1(10.75)$ & $\begin{array}{l}272.7(10.73) \\
265.5(10.45)\end{array}$ \\
\hline & \multicolumn{2}{|c|}{ Below 3D } & --- & $257.4(10.13)[2.49]^{4,5}$ \\
\hline & \multicolumn{2}{|c|}{ Between 2A \& 4A } & $254.8(10.03)$ & $258.0(10.16)$ \\
\hline & \multicolumn{2}{|c|}{ Between 2B \& 4B } & --- & $229.4(9.03)$ \\
\hline & \multicolumn{2}{|c|}{ Between 2C \& 4C } & $263.5(10.38)$ & $281.8(11.09)$ \\
\hline \multicolumn{5}{|c|}{$\begin{array}{l}\text { Detailed in Figure } 6 . \\
{ }^{2} \text { ASTM E } 965 \text { (ASTM 2000b). Dashed lines indicate that no data were obtained. } \\
3 \text { Coefficient of variation (std. dev./mean) of four separate tests conducted July } 2000 . \\
{ }^{4} \text { Tests conducted February } 2001 . \\
{ }^{5} \text { Value in brackets is COV from three separate tests. }\end{array}$} \\
\hline
\end{tabular}

\section{Grip Tester}

The test results obtained by the Grip Tester device are given in Tables 19 and 20 for MacDill AFB and in Table 21 for McGuire AFB. The mean reported value is based on from five to seven values, depending upon the length of section tested and the results obtained. The statistical consistencies of these results are reported by providing the COV for each mean value. 


\begin{tabular}{|c|c|c|c|c|}
\hline \multicolumn{5}{|c|}{$\begin{array}{l}\text { Table } 14 \\
\text { Results of Pavement Texture Tests on TW M at MacDill AFB }\end{array}$} \\
\hline \multirow[b]{2}{*}{ Material } & \multirow[b]{2}{*}{ Area $^{1}$} & \multirow[b]{2}{*}{ Section $^{1}$} & \multicolumn{2}{|c|}{$\begin{array}{ll}\text { Sand Patch }{ }^{2} \text {, Diameter, } \mathrm{mm} \text { (in.) } \\
\end{array}$} \\
\hline & & & August 2000 & August 2001 \\
\hline \multirow[t]{2}{*}{ PolyTar } & \multirow[t]{2}{*}{5} & A & $\begin{array}{l}228.6(9.00) \\
219.1(8.63) \\
\end{array}$ & $240.1(9.45)$ \\
\hline & & $\mathrm{B}$ & --- & $211.1(8.31)$ \\
\hline PAS & \multirow[t]{2}{*}{6} & $\mathrm{~A}$ & $\begin{array}{l}242.9(9.56) \\
256.4(10.09) \\
\end{array}$ & $\begin{array}{l}247.7(9.75)^{3} \\
242.9(9.56)\end{array}$ \\
\hline CBRT-SO & & B & $\begin{array}{l}244.5(9.63) \\
263.5(10.38) \\
\end{array}$ & $\begin{array}{l}240.9(9.48)^{3} \\
260.4(10.25)\end{array}$ \\
\hline APR-100 & 7 & A & $\begin{array}{l}273.1(10.75) \\
270.7(10.66)\end{array}$ & $248.0(9.77)$ \\
\hline CBRT-SO & 8 & A & $\begin{array}{l}256.4(10.09) \\
261.9(10.31)\end{array}$ & $245.7(9.67)$ \\
\hline CPR & 10 & $\mathrm{~A}$ & --- & $\begin{array}{l}231.0(9.09)^{3} \\
223.0(8.78)^{3} \\
247.3(9.73)\end{array}$ \\
\hline \multirow[t]{7}{*}{ Uncoated } & \multicolumn{2}{|c|}{ Above 5A } & --- & $224.6(8.84)$ \\
\hline & \multicolumn{2}{|c|}{ Above 5B } & $\begin{array}{l}218.3(8.59) \\
233.4(9.19) \\
\end{array}$ & $210.3(8.28)$ \\
\hline & \multicolumn{2}{|c|}{ Above $6 \mathrm{~A}$} & $233.4(9.19)$ & $219.1(8.63)$ \\
\hline & \multicolumn{2}{|c|}{ Above 6B } & $\begin{array}{l}228.6(9.00) \\
230.2(9.06)\end{array}$ & $228.2(8.98)$ \\
\hline & \multicolumn{2}{|c|}{ Below 7A } & $\begin{array}{l}242.9(9.56) \\
261.9(10.31) \\
\end{array}$ & $\begin{array}{l}242.9(9.56)^{3} \\
217.1(8.55) \\
\end{array}$ \\
\hline & \multicolumn{2}{|c|}{ Between 8A \& 10A } & $234.2(9.22)$ & $\begin{array}{l}218.3(8.59) \\
238.9(9.41) \\
\end{array}$ \\
\hline & \multicolumn{2}{|c|}{ Between 10A \& center line } & --- & $\begin{array}{l}226.6(8.92)^{3} \\
222.3(8.75)^{3} \\
\end{array}$ \\
\hline
\end{tabular}

\section{Saab Friction Tester (SFT)}

The SFT was used to evaluate the test sections at McGuire AFB and the results are given in Table 21. The results reported in Table 21 are the average of three separate test runs. The values obtained with the SFT do not directly correlate with the results obtained with the Grip Tester; however, they did indicate similar trends regarding low and high values of skid resistance.

\section{Laboratory Results}

\section{Material properties}

The material properties of several rejuvenator and seal coat materials are given in Table 22. The specific tests performed on the materials depended on their composition (i.e., emulsion or solvent based). As these materials are proprietary products there were no requirements for them to meet. 


\begin{tabular}{|c|c|c|c|c|}
\hline \multicolumn{5}{|c|}{$\begin{array}{l}\text { Table } 15 \\
\text { Results of Pavement Texture Tests on TW L at McGuire AFB }\end{array}$} \\
\hline \multirow[b]{2}{*}{ Material } & \multirow{2}{*}{ Area $^{1}$} & \multirow{2}{*}{ Section $^{1}$} & \multicolumn{2}{|c|}{ Sand Patch ${ }^{2}$, Diameter, $\mathrm{mm}$ (in.) } \\
\hline & & & August 2000 & July 2001 \\
\hline \multirow[t]{3}{*}{$\overline{\text { GSB-mod }}$} & \multirow[t]{3}{*}{$\begin{array}{ll}1 \\
\end{array}$} & $\overline{\mathrm{A}}$ & $258.4(10.17)$ & $281.8(11.09)$ \\
\hline & & C & $282.6(11.13)$ & -- \\
\hline & & $\mathrm{D}$ & $276.6(10.89)$ & $299.2(11.78)$ \\
\hline \multirow{3}{*}{$\begin{array}{l}\text { Rejuva- } \\
\text { Seal N }\end{array}$} & \multirow[t]{3}{*}{2} & A & $264.7(10.42)$ & $288.1(11.34)$ \\
\hline & & $\mathrm{B}$ & $290.1(11.42)$ & $290.5(11.44)$ \\
\hline & & $\mathrm{F}$ & $322.3(12.69)$ & $298.5(11.75)$ \\
\hline \multirow[t]{3}{*}{ BCR-2000 } & \multirow[t]{3}{*}{2} & $\mathrm{C}$ & $288.0(11.34)$ & $296.9(11.69)$ \\
\hline & & $\mathrm{D}$ & $249.6(9.83)$ & $271.1(10.67)$ \\
\hline & & $\mathrm{E}$ & $300.4(11.83)$ & $284.6(11.20)$ \\
\hline \multirow[t]{2}{*}{ Reclamite } & \multirow[t]{2}{*}{3} & A & $\begin{array}{l}263.1(10.36)^{3} \\
262.3(10.33)^{3}\end{array}$ & $277.8(10.94)$ \\
\hline & & $\mathrm{D}$ & $\begin{array}{l}271.9(10.70)^{3} \\
265.9(10.47)^{3}\end{array}$ & $285.8(11.25)$ \\
\hline PolyTar & \multirow[t]{5}{*}{4} & $\bar{A}$ & $246.9(9.72)$ & --- \\
\hline \multirow{2}{*}{ CBRT-SO } & & $\mathrm{B}$ & $302.5(11.91)$ & $276.6(10.89)$ \\
\hline & & $\mathrm{C}$ & $277.4(10.92)$ & $296.5(11.67)$ \\
\hline PAS & & $\mathrm{D}$ & $301.2(11.86)$ & $317.5(12.50)$ \\
\hline CPR & & $\mathrm{E}$ & -- & $288.9(11.38)$ \\
\hline $\begin{array}{l}\text { RejuvaSeal } \\
500\end{array}$ & \multirow[t]{4}{*}{5} & $A$ & $290.5(11.44)^{3}$ & $327.8(12.91)$ \\
\hline BCR-3000 & & $\mathrm{B}$ & $300.4(11.83)^{3}$ & $281.4(11.08)$ \\
\hline \multirow[t]{2}{*}{ AR-2000 } & & $\mathrm{C}$ & $257.2(10.13)^{3}$ & $265.1(10.44)$ \\
\hline & & $\mathrm{D}$ & $282.6(11.13)^{3}$ & $264.7(10.42)$ \\
\hline LAS-320 & \multirow[t]{2}{*}{6} & $A$ & -- & $304.4(11.98)$ \\
\hline APR-100 & & $\mathrm{B}$ & $263.1(10.36)^{3}$ & $262.3(10.33)$ \\
\hline \multirow[t]{23}{*}{ Uncoated } & \multicolumn{2}{|c|}{ Above 1A } & -- & $253.6(9.98)$ \\
\hline & \multicolumn{2}{|c|}{ Above 1D } & -- & $274.2(10.80)$ \\
\hline & \multicolumn{2}{|c|}{ Above $2 A$} & --- & $276.6(10.89)$ \\
\hline & \multicolumn{2}{|c|}{ Above 2B } & --- & $281.0(11.06)$ \\
\hline & Above & & --- & $256.4(10.09)$ \\
\hline & Above & & --- & $263.9(10.39)$ \\
\hline & Above & & --- & $285.8(11.25)$ \\
\hline & Above & & --- & $229.4(9.03)$ \\
\hline & Betwe & $1 \mathrm{~A} \& 3 \mathrm{~A}$ & --- & $258.8(10.19)$ \\
\hline & Betwe & $1 D \& 3 D$ & $\begin{array}{l}266.3(10.48) \\
256.8(10.11)\end{array}$ & $252.4(9.94)$ \\
\hline & Betwe & $2 A \& 4 A$ & $279.0(10.98)$ & --- \\
\hline & Betwe & $2 B \& 4 B$ & -- & $269.9(10.63)$ \\
\hline & Betwe & $2 C \& 4 C$ & -- & $282.2(11.11)$ \\
\hline & Betwe & $2 D \& 4 D$ & -- & $248.8(9.80)$ \\
\hline & Betwe & $2 \mathrm{E} \& 4 \mathrm{E}$ & --- & $267.9(10.55)$ \\
\hline & Betwe & $3 A \& 5 A$ & $306.8(12.08)$ & $290.5(11.44)$ \\
\hline & Betwe & $3 B \& 5 B$ & -- & $275.8(10.86)$ \\
\hline & Betwe & $3 C \& 5 C$ & --- & $242.5(9.55)$ \\
\hline & Betwe & $3 D \& 5 D$ & --- & $260.4(10.25)$ \\
\hline & Betwe & $4 \mathrm{~A} \& 6 \mathrm{~A}$ & --- & $264.7(10.42)$ \\
\hline & Betwe & $4 \mathrm{~B} \& 6 \mathrm{~B}$ & --- & $265.9(10.47)$ \\
\hline & Betwe & $4 \mathrm{D} \& 6 \mathrm{D}$ & $283.4(11.16)$ & -- \\
\hline & Betwe & $2 \mathrm{C}$ and $2 \mathrm{D}$ & $281.0(11.06)$ & --- \\
\hline
\end{tabular}




\begin{tabular}{|c|c|c|c|c|}
\hline \multicolumn{5}{|c|}{$\begin{array}{l}\text { Table } 16 \\
\text { Results of British Pendulum Tests on TW O at MacDill AFB }\end{array}$} \\
\hline \multirow[b]{2}{*}{ Material } & \multirow[b]{2}{*}{ Area } & \multirow[b]{2}{*}{ Section $^{1}$} & \multicolumn{2}{|c|}{ British Pendulum ${ }^{2}$ - BPN, Temperature ${ }^{\circ} \mathrm{C}\left({ }^{\circ} \mathrm{F}\right)$} \\
\hline & & & Date Tested (2000) & August 2001 \\
\hline \multirow[t]{2}{*}{ BCR-2000 } & \multirow[t]{3}{*}{ 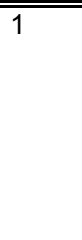 } & $\overline{\mathrm{A} A}$ & $\begin{array}{l}(8 / 24) 35,39(102) \\
(8 / 26) 20,32(90)\end{array}$ & $\begin{array}{l}\mathbf{4 2 ,}, 40(104)^{4} \\
\mathbf{4 3 ,}, 40(104)^{4} \\
\mathbf{4 9 ,} 39(102)\end{array}$ \\
\hline & & $\mathrm{B}$ & $\begin{array}{l}(8 / 24) 66^{3}, 39(102) \\
(8 / 26) 45^{3}, 32(90)\end{array}$ & $59,39(102)$ \\
\hline BCR-3000 & & $\mathrm{C}$ & $\begin{array}{l}(8 / 24) 39,39(102) \\
(8 / 26) 20^{3}, 32(90)\end{array}$ & $44,39(102)$ \\
\hline RejuvaSeal 50 & \multirow[t]{3}{*}{2} & $A$ & $(8 / 24) 36,46(115)$ & $52,40(104)$ \\
\hline \multirow[t]{2}{*}{ RejuvaSeal N } & & $\mathrm{B}$ & $(8 / 24) 61,46(115)$ & $64,40(104)$ \\
\hline & & $\mathrm{C}$ & $(8 / 24) 42,46(115)$ & $\begin{array}{l}\mathbf{5 2 ,}, 40(104)^{4} \\
\mathbf{5 0}, 40(104)^{4} \\
\mathbf{5 8}, 40(104)\end{array}$ \\
\hline \multirow[t]{3}{*}{ Reclamite } & \multirow[t]{4}{*}{3} & A & $(8 / 26) 66^{3}, 32(90)$ & $\begin{array}{l}\mathbf{8 0}, 33(92)^{4} \\
82,33(92)^{4} \\
\mathbf{7 6}, 40(104)\end{array}$ \\
\hline & & $\mathrm{B}$ & --- & $83,40(104)$ \\
\hline & & $\mathrm{C}$ & --- & $80,40(104)$ \\
\hline Antiskid & & $\mathrm{D}$ & --- & $\begin{array}{l}77,33(91)^{4} \\
83,33(91)^{4}\end{array}$ \\
\hline \multirow[t]{3}{*}{ GSB-mod } & \multirow[t]{3}{*}{4} & A & $\begin{array}{l}(8 / 24) 56^{3}, 45(113) \\
(8 / 24) 56^{3}, 45(113)\end{array}$ & $69,39(102)$ \\
\hline & & $\mathrm{B}$ & $\begin{array}{l}(8 / 24) 65,45(113) \\
(8 / 24) 52^{3}, 45(113)\end{array}$ & $67,39(102)$ \\
\hline & & $\mathrm{C}$ & $\begin{array}{l}(8 / 24) 55,45(113) \\
(8 / 24) 40,45(113)\end{array}$ & $\begin{array}{l}\mathbf{4 6}, 39(103)^{4} \\
\mathbf{5 0}, 39(103)^{4} \\
\mathbf{6 4}, 39(102)\end{array}$ \\
\hline \multirow[t]{6}{*}{ Uncoated } & \multicolumn{2}{|c|}{ Between 1A \& 3A } & $(8 / 26) 65^{3}, 32(90)$ & $82,40(104)$ \\
\hline & \multicolumn{2}{|c|}{ Between 1B \& 3B } & -- & $82,40(104)$ \\
\hline & \multicolumn{2}{|c|}{ Between $1 \mathrm{C} \& 3 \mathrm{C}$} & $(8 / 26) 45^{3}, 32(90)$ & $81,40(104)$ \\
\hline & \multicolumn{2}{|c|}{ Between 2A \& 4A } & $(8 / 26) 35,32(90)$ & $78,39(102)$ \\
\hline & \multicolumn{2}{|c|}{ Between 2B \& 4B } & -- & $79,39(102)$ \\
\hline & \multicolumn{2}{|c|}{ Between 2C \& 4C } & --- & $82,39(102)$ \\
\hline \multicolumn{5}{|c|}{$\begin{array}{l}\text { Detailed in Figure } 6 . \\
2 \text { ASTM E } 303 \text { (ASTM 2000c). Dashed lines indicate that no data obtained. } \\
{ }^{3} \text { Values varied more than allowed in ASTM E } 303 \text { (ASTM 2000c). } \\
{ }^{4} \text { Tests conducted February 2001. }\end{array}$} \\
\hline
\end{tabular}

\section{Penetration and viscosity results}

Tables 23, 24, and 25 list the values obtained for penetration and viscosity of the extracted asphalt cements from the prepared core specimens from MacDill and McGuire AFBs, respectively. These tables show that the values for the penetration didn't show a consistent softening or lower penetration in all cases for either location. The Kinematic viscosity tests results showed a lowering of viscosity at both locations. Tables 23 and 24 for MacDill AFB are plotted in Figure 32 and from McGuire AFB in Figure 33. The numbers listed above some of the plotted bar values indicate the number of individual viscosity tests upon which the value is based. These data show that the rejuvenator materials were successful in lowering the viscosity of the asphalt cement binder, both initially and after 1 year of service. The removal of the top $1 \mathrm{~mm}(0.04 \mathrm{in}$.) from the cores prior to the extraction of the asphalt cement binder appeared to affect the results, but the effect was not consistent between the bases or the various rejuvenator materials. 


\begin{tabular}{|c|c|c|c|c|}
\hline \multicolumn{5}{|c|}{$\begin{array}{l}\text { Table } 17 \\
\text { Results of British Pendulum Tests on TW M at MacDill AFB }\end{array}$} \\
\hline \multirow[b]{2}{*}{ Material } & \multirow[b]{2}{*}{ Area } & \multirow[b]{2}{*}{ Section $^{1}$} & \multicolumn{2}{|c|}{ British Pendulum ${ }^{2}-\mathrm{BPN}$, Temperature ${ }^{\circ} \mathrm{C}\left({ }^{\circ} \mathrm{F}\right)$} \\
\hline & & & August 2000 & August 2001 \\
\hline \multirow[t]{2}{*}{ PolyTar } & \multirow[t]{2}{*}{5} & 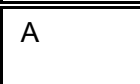 & $\begin{array}{l}7^{3}, 29(83) \\
80^{3}, 29(83)\end{array}$ & 58, $34(93)$ \\
\hline & & $\mathrm{B}$ & --- & $60,34(93)$ \\
\hline CBRT-SO & \multirow[t]{2}{*}{6} & $\mathrm{~A}$ & --- & 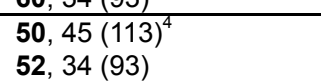 \\
\hline PAS & & $\mathrm{B}$ & $\begin{array}{l}3 \mathbf{3 0}^{3}, 29(83) \\
\mathbf{5 6}^{3}, 29(83)\end{array}$ & $\begin{array}{l}\mathbf{7 0}, 46(114)^{4} \\
\mathbf{7 5}, 45(113)^{4} \\
\mathbf{7 5}, 34(93)\end{array}$ \\
\hline APR-100 & 7 & A & $\begin{array}{l}\mathbf{4 5}^{3}, 29(83) \\
35,29(83)\end{array}$ & $\begin{array}{l}\mathbf{6 3}, 46(114)^{4} \\
\mathbf{6 5}, 46(114)^{4} \\
\mathbf{7 0}, 33(91)\end{array}$ \\
\hline CBRT-SO & 8 & A & $\begin{array}{l}35,29(83) \\
25^{3}, 29(83)\end{array}$ & $\begin{array}{l}\mathbf{4 6}, 46(114)^{4} \\
\mathbf{4 6}, 46(114)^{4} \\
\mathbf{4 7}, 33(91)\end{array}$ \\
\hline CPR & 10 & $\bar{A}$ & --- & 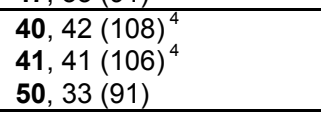 \\
\hline \multirow[t]{9}{*}{ Uncoated } & \multicolumn{2}{|c|}{ Above $5 A$} & --- & $80,33(91)$ \\
\hline & \multicolumn{2}{|c|}{ Above 5B } & --- & $84,34(93)$ \\
\hline & \multicolumn{2}{|c|}{ Above 6A } & --- & $82,34(93)$ \\
\hline & \multicolumn{2}{|c|}{ Above 6B } & --- & $81,34(93)$ \\
\hline & \multicolumn{2}{|c|}{ Below 7A } & --- & $82,33(91)$ \\
\hline & \multicolumn{2}{|c|}{ Below 8A } & --- & $83,33(91)$ \\
\hline & \multicolumn{2}{|c|}{ Below 10A } & --- & $82,33(91)$ \\
\hline & \multirow{2}{*}{\multicolumn{2}{|c|}{$\begin{array}{l}\text { Between 5B \& 7A } \\
\text { Between 6A \& 8A }\end{array}$}} & $60^{3}, 29(83)$ & $84,34(94)^{4}$ \\
\hline & & & $70^{3}, 29(83)$ & $85,34(94)^{4}$ \\
\hline \multicolumn{5}{|c|}{$\begin{array}{l}\text { Detailed in Figure } 7 \\
2 \text { ASTM E } 303 \text { (ASTM 2000c). Dashed lines indicate no data obtained. } \\
3 \text { Values varied more than allowed in ASTM E } 303 \text { (ASTM 2000c). } \\
4 \text { Tests conducted February } 2001 .\end{array}$} \\
\hline
\end{tabular}

\section{Dynamic shear rheometer results}

The results of the DSR testing are shown in Tables 23 and 24 for MacDill AFB and in Table 25 for McGuire AFB. Figures 19 and 20 show the same results in graphical form for MacDill AFB and McGuire AFB, respectively. The results from the samples taken in 2000 and 2001 showed that each rejuvenator had softened the recovered asphalt binder. In all extracted specimens the binder had a higher phase angle (softer, more viscous) than the control specimens, even after one year.

The removal of the top $1 \mathrm{~mm}$ (0.04 in.) showed that, as expected, the binder was harder on the surface. Figures 34 and 35 also showed that the coal tar based rejuvenators, when compared to the asphalt-based materials, had a greater difference in phase angle between samples at the surface and with the top $1 \mathrm{~mm}$ (0.04 in.) removed. The amount of data is limited; however, it may indicate that the coal-tar material remaining on the surface was hardening providing the same effect as was observed by the Missouri Department of Transportation (Shipman 2001). 


\begin{tabular}{|c|c|c|c|c|}
\hline \multicolumn{5}{|c|}{$\begin{array}{l}\text { Table } 18 \\
\text { Results of British Pendulum Tests on TW L at McGuire AFB }\end{array}$} \\
\hline \multirow[b]{2}{*}{ Material } & \multirow[b]{2}{*}{ Area } & \multirow[b]{2}{*}{ Section $^{1}$} & \multicolumn{2}{|c|}{ British Pendulum $^{2}$ - BPN, Temperature ${ }^{\circ} \mathrm{C}\left({ }^{\circ} \mathrm{F}\right)$} \\
\hline & & & Date Tested (2000) & August 2001 \\
\hline GSB-mod & 1 & $\mathrm{D}$ & $(8 / 2) 60^{3}, 43(110)$ & 64, $27(81)$ \\
\hline \multirow{3}{*}{ RejuvaSeal N } & \multirow[t]{3}{*}{2} & A & --- & $56,27(81)$ \\
\hline & & $\mathrm{B}$ & $\begin{array}{l}(8 / 3) 48,33(91) \\
(8 / 4) 47,30(86)\end{array}$ & $58,27(81)$ \\
\hline & & $\mathrm{F}$ & $\begin{array}{l}(8 / 3) 57,32(90) \\
(8 / 4) 36,32(86)\end{array}$ & $61,28(83)$ \\
\hline \multirow[t]{3}{*}{ BCR-2000 } & \multirow[t]{3}{*}{2} & $\mathrm{C}$ & $\begin{array}{l}(8 / 3) 42,32(90) \\
(8 / 4) 28,30(86) \\
\end{array}$ & $58,28(83)$ \\
\hline & & $\mathrm{D}$ & --- & $57,28(83)$ \\
\hline & & $\mathrm{E}$ & $\begin{array}{l}(8 / 3) \text { 40, } 32(90) \\
(8 / 4) 39,30(86)\end{array}$ & $54,28(83)$ \\
\hline \multirow[t]{4}{*}{ Reclamite } & \multirow[t]{4}{*}{3} & A & $(8 / 5) 60,18(65)$ & $77,29(84)$ \\
\hline & & $\mathrm{B}$ & $(8 / 5) 60,19(66)$ & --- \\
\hline & & $\mathrm{C}$ & $(8 / 5) 43,19(66)$ & --- \\
\hline & & $\mathrm{D}$ & $(8 / 5) 57,19(66)$ & $\mathbf{5 7}, 39(102)$ \\
\hline PolyTar & \multirow[t]{5}{*}{4} & A & $(8 / 5) 54,29(85)$ & 46, 43 (109) \\
\hline \multirow[t]{2}{*}{ CBRT-SO } & & $\mathrm{B}$ & $(8 / 5) 45,24(75)$ & $50,42(108)$ \\
\hline & & $\mathrm{C}$ & $(8 / 5) 75,26(79)$ & $56,40(104)$ \\
\hline PAS & & $\mathrm{D}$ & $(8 / 5) 76,25(77)$ & $\mathbf{7 1 ,} 40(104)$ \\
\hline CPR & & $\mathrm{E}$ & -- & $47,40(104)$ \\
\hline $\begin{array}{l}\text { RejuvaSeal } \\
500\end{array}$ & \multirow[t]{2}{*}{5} & $A$ & $\begin{array}{l}(9 / 20) 40,34(93) \\
(9 / 20) 43,34(93)\end{array}$ & $46,40(104)$ \\
\hline BCR-3000 & & $\mathrm{B}$ & $(9 / 20) 45,34(93)$ & \\
\hline \multirow[t]{2}{*}{ AR-2000 } & \multirow[t]{2}{*}{5} & $\mathrm{C}$ & $\begin{array}{l}(9 / 20) 40,34(93) \\
(9 / 20) 41,34(93)\end{array}$ & $40,40(104)$ \\
\hline & & $\mathrm{D}$ & $\begin{array}{l}(9 / 20) 39^{3}, 34(93) \\
(9 / 20) 38,34(93)\end{array}$ & $42,40(104)$ \\
\hline LAS-320 & \multirow[t]{3}{*}{6} & $A$ & -- & 43, $40(104)$ \\
\hline APR-100 & & $\mathrm{B}$ & $\begin{array}{l}(9 / 20) 65,34(93) \\
(9 / 20) 67,34(93)\end{array}$ & $62,40(104)$ \\
\hline CPR & & $\mathrm{C}$ & -- & 40, $40(104)$ \\
\hline \multirow[t]{22}{*}{ Uncoated } & \multicolumn{2}{|c|}{ Above 1D } & --- & $68,27(81)$ \\
\hline & \multicolumn{2}{|c|}{ Above $2 \mathrm{~A}$} & --- & $61,27(81)$ \\
\hline & \multicolumn{2}{|c|}{ Above 2B } & $(8 / 2) 66^{3}, 36(97)$ & $72,27(81)$ \\
\hline & \multicolumn{2}{|c|}{ Above $2 \mathrm{C}$} & -- & $74,28(83)$ \\
\hline & Abov & & --- & $79,28(83)$ \\
\hline & Abov & & --- & $74,28(83)$ \\
\hline & Abov & & --- & $84,28(83)$ \\
\hline & Betw & $1 \mathrm{~A} \& 3 \mathrm{~A}$ & --- & $71,30(86)$ \\
\hline & Betwe & 1D \& 3D & --- & $61,39(102)$ \\
\hline & Betwe & 2B \& 4B & --- & $68,42(108)$ \\
\hline & Betw & $2 C \& 4 C$ & --- & $72,40(104)$ \\
\hline & Betw & $2 D \& 4 D$ & --- & $68,40(104)$ \\
\hline & Betwe & $2 \mathrm{E} \& 4 \mathrm{E}$ & --- & $59,40(104)$ \\
\hline & Betw & $2 \mathrm{~F} \& 4 \mathrm{~F}$ & $(8 / 3) 60^{3}, 31(88)$ & --- \\
\hline & Betws & $3 A \& 5 A$ & $(9 / 20) 57^{3}, 34(93)$ & $60,40(104)$ \\
\hline & Betwe & $3 C \& 5 C$ & -- & $50,40(104)$ \\
\hline & Betwe & $3 D \& 5 D$ & $(9 / 20) 63^{3}, 34(93)$ & --- \\
\hline & Betw & \& Left 3D \& 5D & $(9 / 20) 63^{3}, 34(93)$ & --- \\
\hline & Betwe & $4 A \& 6 A$ & -- & 62, $41(106)$ \\
\hline & Betwe & $4 \mathrm{~B} \& 6 \mathrm{~B}$ & --- & 66, $41(106)$ \\
\hline & Betw & $4 C \& 6 C$ & --- & 64, $41(106)$ \\
\hline & Betwe & $4 \mathrm{D} \& 6 \mathrm{D}$ & $(8 / 5) 63,23(74)$ & --- \\
\hline & & & & (Continued) \\
\hline $\begin{array}{l}1 \text { Detaile } \\
{ }_{2}^{2} \text { ASTM } \\
{ }^{3} \text { Values }\end{array}$ & e 17. & $\Omega$ & te no data obtained & \\
\hline
\end{tabular}




\begin{tabular}{|c|c|c|c|c|}
\hline Table 1 & \multirow[b]{2}{*}{ Area } & & \multicolumn{2}{|c|}{ British Pendulum $^{2}-\mathrm{BPN}$, Temperature ${ }^{\circ} \mathrm{C}\left({ }^{\circ} \mathrm{F}\right)$} \\
\hline Material & & Section $^{1}$ & Date Tested (2000) & August 2001 \\
\hline \multirow{7}{*}{$\begin{array}{l}\text { Uncoated } \\
\text { (Cont'd) }\end{array}$} & \multicolumn{2}{|l|}{ 1D } & $(8 / 1) 63,34(93)$ & (--- \\
\hline & \multicolumn{2}{|c|}{$2 \mathrm{~A}$} & $(8 / 1) 56,34(94)$ & --- \\
\hline & \multicolumn{2}{|c|}{ Between 3B and $3 \mathrm{C}$} & $(8 / 5) 76,18(65)$ & --- \\
\hline & \multicolumn{2}{|c|}{$3 \mathrm{D}$} & $(8 / 1) 44^{2}, 34(94)$ & --- \\
\hline & \multicolumn{2}{|l|}{$4 \mathrm{~A}$} & $(8 / 1) 49,34(94)$ & --- \\
\hline & \multicolumn{2}{|l|}{$5 D$} & $(8 / 2) 48,37(98)$ & --- \\
\hline & \multicolumn{2}{|l|}{$6 \mathrm{~A}$} & $(8 / 2) 58,36(97)$ & --- \\
\hline
\end{tabular}

\begin{tabular}{|c|c|c|c|c|c|c|}
\hline \multicolumn{7}{|c|}{$\begin{array}{l}\text { Table } 19 \\
\text { Results of Grip Tester Friction Testing on TW O at MacDill AFB }\end{array}$} \\
\hline \multirow[b]{3}{*}{ Material } & \multirow[b]{3}{*}{ Area } & \multirow[b]{3}{*}{ Section $^{1}$} & \multicolumn{4}{|c|}{ Mu value ${ }^{2}\left(2000 / 2001^{3}\right)$} \\
\hline & & & \multicolumn{2}{|c|}{$64.4 \mathrm{kmph}(40 \mathrm{mph})$} & \multicolumn{2}{|c|}{$96.6 \mathrm{kmph}(60 \mathrm{mph})$} \\
\hline & & & Mean & $\mathrm{Cov}^{4}$ & Mean & $\mathrm{COV}^{4}$ \\
\hline \multirow[t]{2}{*}{ BCR-2000 } & \multirow[t]{3}{*}{1} & A & $0.34 / 0.43$ & $7.44 / 4.74$ & $0.21 / 0.28$ & $9.64 / 4.07$ \\
\hline & & $\mathrm{B}^{5}$ & $0.67 / 0.63$ & $3.31 / 3.86$ & $0.49 / 0.42$ & $5.81 / 4.31$ \\
\hline BCR-3000 & & C & $0.43 / 0.52$ & $3.25 / 5.40$ & $0.28 / 0.40$ & $8.53 / 6.85$ \\
\hline RejuvaSeal 50 & \multirow[t]{3}{*}{2} & A & $0.39 / 0.52$ & $2.15 / 7.63$ & $0.31 / 0.39$ & $10.5 / 12.00$ \\
\hline \multirow[t]{2}{*}{ RejuvaSeal N } & & $\mathrm{B}^{5}$ & $0.62 / 0.68$ & $2.63 / 5.47$ & $0.48 / 0.48$ & $3.93 / 11.54$ \\
\hline & & $\mathrm{C}$ & $0.42 / 0.54$ & $8.17 / 5.43$ & $0.26 / 0.51$ & $15.7 / 13.75$ \\
\hline \multirow[t]{3}{*}{ Reclamite } & \multirow[t]{4}{*}{3} & $\mathrm{~A}$ & $0.70 / 0.76$ & $1.67 / 1.54$ & $0.54 / 0.58$ & $4.48 / 3.57$ \\
\hline & & $\mathrm{B}$ & $0.72 / 0.78$ & $2.83 / 3.77$ & $0.54 / 0.58$ & $3.04 / 3.21$ \\
\hline & & $\mathrm{C}$ & $0.75 / 0.80$ & $2.16 / 4.19$ & $0.60 / 0.63$ & $7.60 / 10.79$ \\
\hline Antiskid & & $\mathrm{D}$ & $---/ 0.86$ & $---/ 4.24$ & $---/ 0.64$ & $---/ 7.13$ \\
\hline \multirow[t]{3}{*}{ GSB-mod } & \multirow[t]{3}{*}{4} & $A^{5}$ & $0.62 / 0.70$ & $3.37 / 4.09$ & $0.51 / 0.56$ & $7.17 / 10.09$ \\
\hline & & $\mathrm{B}^{5}$ & $0.65 / 0.70$ & $1.87 / 3.43$ & $0.50 / 0.50$ & $5.50 / 10.02$ \\
\hline & & $\mathrm{C}^{5}$ & $0.57 / 0.58$ & $4.56 / 5.62$ & $0.36 / 0.51$ & $10.7 / 10.16$ \\
\hline \multirow[t]{7}{*}{ Uncoated } & \multicolumn{2}{|c|}{ South of Area 3A } & $0.73 / 0.80$ & $1.51 / 1.29$ & $0.61 / 0.63$ & $3.36 / 5.08$ \\
\hline & \multicolumn{2}{|c|}{ South of Area 3B } & $0.73 / 0.80$ & $1.59 / 2.55$ & $0.61 / 0.59$ & $6.13 / 6.03$ \\
\hline & \multicolumn{2}{|c|}{ South of Area $3 C$} & $0.75 / 0.84$ & $2.57 / 2.88$ & $0.61 / 0.65$ & $5.35 / 7.58$ \\
\hline & \multicolumn{2}{|c|}{ South of Area 3D } & $---/ 0.81$ & $---/ 4.51$ & $---/ 0.78$ & $---/ 1.05$ \\
\hline & \multicolumn{2}{|c|}{ South of Area 4A } & $0.73 / 0.87$ & $1.26 / 1.93$ & $0.58 / 0.67$ & $3.99 / 7.34$ \\
\hline & \multicolumn{2}{|c|}{ South of Area 4B } & $0.73 / 0.84$ & $0.88 / 3.08$ & $0.61 / 0.68$ & $4.54 / 4.31$ \\
\hline & \multicolumn{2}{|c|}{ South of Area 4C } & $0.71 / 0.81$ & $4.43 / 6.42$ & $0.57 / 0.91$ & $12.0 / 2.09$ \\
\hline \multicolumn{7}{|c|}{$\begin{array}{l}{ }^{1} \text { Detailed in Figure } 6 . \\
{ }^{2} \text { Values given are based on from } 5 \text { to } 7 \text { values. Grip Tester provides average value every } 15.2 \mathrm{~m} \\
(50 \mathrm{ft}) . \text { Dashed lines indicate no data obtained. } \\
\left({ }^{3} \text { Tested March } 2001 .\right. \\
{ }^{4} \text { Coefficient of variation (std. dev./ mean) } \times 100 . \\
{ }^{5} \text { Sanded. }\end{array}$} \\
\hline
\end{tabular}




\begin{tabular}{|c|c|c|c|c|c|c|}
\hline $\begin{array}{l}\text { Table } 2 \\
\text { Results }\end{array}$ & f Gri & Tester I & tion Tes & ig on TV & at $\mathrm{Ma}$ & AFB \\
\hline & & & & Mu valu & $2000 / 2001^{3}$ & \\
\hline & & & $64.4 \mathrm{kr}$ & (40 mph) & $96.6 \mathrm{k}$ & (60 mph) \\
\hline Material & Area & Section ${ }^{1}$ & Mean & $\mathrm{COV}^{4}$ & Mean & $\mathrm{COV}^{4}$ \\
\hline PolyTar & 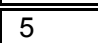 & $\overline{A A}$ & $\overline{0.60 / 0.67}$ & ב3.58/2.87 & "0.48/0.53 & $20.76 / 5.55$ \\
\hline & & B & $0.65 / 0.76$ & $4.74 / 3.49$ & $0.54 / 0.64$ & $9.13 / 4.39$ \\
\hline CBRT-SO & 6 & $A^{5}$ & $0.46 / 0.58$ & $3.87 / 4.71$ & $0.34 / 0.44$ & $4.34 / 3.11$ \\
\hline PAS & & B & $0.58 / 0.74$ & $4.45 / 1.54$ & $0.44 / 0.58$ & $4.55 / 2.88$ \\
\hline Uncoated & 7 & $\mathrm{~A}$ & $0.75 / 0.80$ & $2.30 / 1.66$ & $0.63 / 0.69$ & $3.37 / 7.75$ \\
\hline APR-100 & & $\mathrm{B}$ & $0.70 / 0.76$ & $2.60 / 2.26$ & $0.48 / 0.60$ & $4.90 / 5.70$ \\
\hline CBRT-SO & 8 & $\mathrm{~A}$ & $0.41 / 0.56$ & $1.84 / 3.13$ & $0.31 / 0.44$ & $3.23 / 3.11$ \\
\hline Uncoated & & $\mathrm{B}$ & $0.82 / 0.90$ & $0.96 / 1.74$ & $0.70 / 0.81$ & $1.98 / 1.70$ \\
\hline CPR & 10 & $A$ & $---/ 0.57$ & $---/ 4.53$ & $---/ 0.44$ & $---/ 4.23$ \\
\hline $\begin{array}{l}\text { " Detailed } \mathrm{i} \\
{ }^{2} \text { Values gi } \\
\text { (50 ft). Da } \\
{ }^{3} \text { Tested M } \\
{ }^{4} \text { Coefficier } \\
{ }^{5} \text { Sanded. }\end{array}$ & $\begin{array}{l}\text { ch } 2001 \\
\text { of variat }\end{array}$ & (std. de & $\begin{array}{l}\text { values. } \\
\text { btained. } \\
\text { n) x } 100 \text {. }\end{array}$ & & & very $15.2 \mathrm{~m}$ \\
\hline
\end{tabular}

\begin{tabular}{|c|c|c|c|c|c|c|c|c|c|c|}
\hline $\begin{array}{l}\text { Table } 21 \\
\text { Results of }\end{array}$ & p T & er anc & Saab & iction & stin & n TW & at $M$ & uire AFE & & \\
\hline & & & & $\mathrm{Mu}$ & alue $^{2}$ & & & & $a b^{3}$ & \\
\hline & & & $64.4 \mathrm{k}$ & $(40 \mathrm{mph})$ & $96.6 \mathrm{k}$ & $(60 \mathrm{mph})$ & $64.4 \mathrm{k}$ & $(40 \mathrm{mph})$ & $96.6 \mathrm{k}$ & $(60 \mathrm{mph})$ \\
\hline Material & Area & Section $^{1}$ & Mean & $\operatorname{cov}^{4}$ & Mean & $\operatorname{cov}^{4}$ & Mean & $\operatorname{cov}^{4}$ & Mean & $\operatorname{cov}^{4}$ \\
\hline$\overline{\text { GSB-mod }}$ & 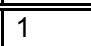 & $A^{5}$ & 0.702 & 2.11 & 0.487 & $\begin{array}{l}3.82 \\
\end{array}$ & $\begin{array}{ll}74 \\
\end{array}$ & $\begin{array}{l}3.58 \\
\end{array}$ & (266 & "0.87 \\
\hline & & $\mathrm{B}^{5}$ & 0.726 & 1.23 & 0.523 & 7.32 & 76 & 3.48 & 66 & 6.28 \\
\hline & & $\mathrm{C}^{5}$ & 0.693 & 2.35 & 0.503 & 6.50 & 70 & 2.47 & 61 & 0.95 \\
\hline & & $\mathrm{D}^{5}$ & 0.680 & 2.94 & 0.543 & 4.60 & 71 & 5.31 & 64 & 8.12 \\
\hline RejuvaSeal N & 2 & $A^{5}$ & 0.660 & 2.87 & 0.476 & 4.10 & 63 & 3.32 & 53 & 2.86 \\
\hline & & B & 0.596 & 2.55 & 0.340 & 7.68 & 63 & 8.79 & 51 & 10.38 \\
\hline & & \begin{tabular}{|l}
$F$ \\
\end{tabular} & --- & --- & --- & --- & 55 & 4.60 & 48 & 9.08 \\
\hline BCR-2000 & & \begin{tabular}{|l}
$\mathrm{C}$ \\
\end{tabular} & 0.494 & 4.43 & 0.268 & 9.66 & 50 & 8.72 & 45 & 0.00 \\
\hline & & $\mathrm{D}^{5}$ & 0.710 & 2.82 & 0.515 & 7.84 & 68 & 5.30 & 54 & 4.63 \\
\hline & & $\mathrm{E}$ & --- & $-\ldots$ & --- & --- & 53 & 2.86 & \begin{tabular}{|l|}
44 \\
\end{tabular} & 1.30 \\
\hline Reclamite & 3 & $\mathrm{~A}$ & 0.580 & 2.10 & 0.378 & 5.09 & $77^{5}$ & 4.16 & \begin{tabular}{|l|}
-- \\
\end{tabular} & ---- \\
\hline & & B & 0.565 & 3.66 & 0.377 & 10.43 & $--^{5}$ & --- & --- & --- \\
\hline & & C & 0.550 & 5.02 & 0.409 & 10.99 & $-\mathrm{-o}^{5}$ & --- & $-\ldots$ & --- \\
\hline & & D & 0.577 & 1.41 & 0.442 & 7.22 & $-\mathrm{-}^{5}$ & --- & --- & --- \\
\hline PolyTar & 4 & $A$ & 0.695 & 7.65 & 0.468 & 11.87 & 61 & 4.10 & 57 & 5.04 \\
\hline CBTR-SO & & B & 0.517 & 4.18 & 0.310 & 13.23 & 52 & 6.66 & 42 & 11.65 \\
\hline & & $\mathrm{C}^{5}$ & 0.623 & 6.79 & 0.473 & 10.33 & 61 & 0.00 & 48 & 2.39 \\
\hline PAS & & $\mathrm{D}$ & 0.502 & 13.65 & 0.360 & 16.08 & 71 & 2.16 & 59 & 5.15 \\
\hline RejuvaSeal 500 & 5 & $\mathrm{~A}$ & --- & $\begin{array}{ll}--- \\
\end{array}$ & --- & ---- & 57 & 1.75 & --- & --- \\
\hline BCR-3000 & & $B$ & --- & --- & \begin{tabular}{|l|}
--- \\
\end{tabular} & --- & 59 & 10.31 & --- & --- \\
\hline AR-2000 & & $\mathrm{C}$ & --- & --- & \begin{tabular}{|c|}
-- \\
\end{tabular} & --- & 52 & 7.72 & 48 & 4.84 \\
\hline & & $\mathrm{D}$ & --- & --- & \begin{tabular}{|l}
--- \\
\end{tabular} & --- & 47 & 2.47 & 42 & 3.67 \\
\hline LAS-320 & & A & ---- & $-\ldots-$ & $-\ldots-$ & --- & 50 & 2.00 & 48 & 6.25 \\
\hline APR-100 & 6 & $B$ & 0.478 & 3.43 & 0.374 & 6.15 & 78 & 0.74 & 71 & 2.44 \\
\hline Uncoated & --- & 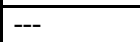 & 0.586 & 2.29 & 0.420 & 7.42 & 83 & 2.50 & 74 & 5.09 \\
\hline & & & 0.575 & 0.95 & 0.457 & 5.01 & --- & --- & --- & $-\ldots$ \\
\hline & & & 0.568 & 4.01 & $-\ldots$ & --- & --- & --- & --- & --- \\
\hline & & & 0.54 & 1.71 & $-{ }_{---}$ & $-\ldots$ & - & --- & \begin{tabular}{|c|}
-- \\
\end{tabular} & $\ldots$ \\
\hline${ }^{1}$ Detailed in Fig & 17 & & & & & & & & & \\
\hline $\begin{array}{l}2 \text { Tested August } 2 \\
{ }^{3} \text { Tested June } 20 \\
{ }^{4} \text { Sanded. } \\
{ }^{5} \text { Sections not vis }\end{array}$ & & 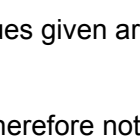 & & m $5 t$ & values & Teste & ovides & ge value & very 15 & (50 ft). \\
\hline
\end{tabular}




\begin{tabular}{|c|c|c|c|c|c|}
\hline \multicolumn{6}{|c|}{\begin{tabular}{|l} 
Table 22 \\
Results of Material Properties Testing \\
\end{tabular}} \\
\hline \multirow[b]{3}{*}{ Material $^{2}$} & \multicolumn{2}{|c|}{ Viscosity } & \multirow{3}{*}{$\begin{array}{l}\text { Water Content, } \\
\text { ASTM D 244 } \\
\text { (ASTM 2000o) (\%) }\end{array}$} & \multirow{3}{*}{\begin{tabular}{|l|} 
Flash Pt., \\
ASTM D92 $^{5}$ \\
$($ ASTM 2000p) \\
${ }^{\circ} \mathrm{C}\left({ }^{\circ} \mathrm{F}\right)$
\end{tabular}} & \multirow{3}{*}{$\begin{array}{l}\text { Percentage of } \\
\text { Residual Matl. } \\
\text { ASTM D 244 } \\
\text { (ASTM 2000o) }\end{array}$} \\
\hline & Sabolt $^{3}$ & Brookfield $^{4}$ & & & \\
\hline & (Seconds) & CentiPoise & & & \\
\hline Reclamite & 31.0 & 153.0 & 39 & \begin{tabular}{|l|l|}
-- \\
\end{tabular} & 61 \\
\hline APR-100 & 82.0 & \begin{tabular}{|c|}
--- \\
\end{tabular} & -- & $33(92)$ & $84.4^{\prime}$ \\
\hline GSB-mod & 159.0 & 669.7 & 37 & --- & 63 \\
\hline BCR-2000 & 171.0 & 129.6 & -- & $60(140)$ & $\begin{array}{l}(10.4,80.3,6.3 \\
3.0)^{8} 66.5\end{array}$ \\
\hline RejuvaSeal N & 31.2 & --- & -- & $97.8(208)$ & $\begin{array}{l}(33.3,54.7,5.4 \\
6.6)^{8} 59.2\end{array}$ \\
\hline LAS-320 & 10.0 & 14.2 & 82 & --- & 18 \\
\hline CRF & 54.0 & 388.2 & 36 & -- & 64 \\
\hline PolyTar & --- & --- & 60 & -- & 40 \\
\hline PAS & 85.0 & --- & -- & $56(132)$ & $52.0^{7}$ \\
\hline $\begin{array}{l}\text { AntiSkid } \\
\text { (Promak A) }\end{array}$ & --- & --- & -- & $-\left.\right|^{--}$ & 51.3 \\
\hline \multicolumn{6}{|c|}{ 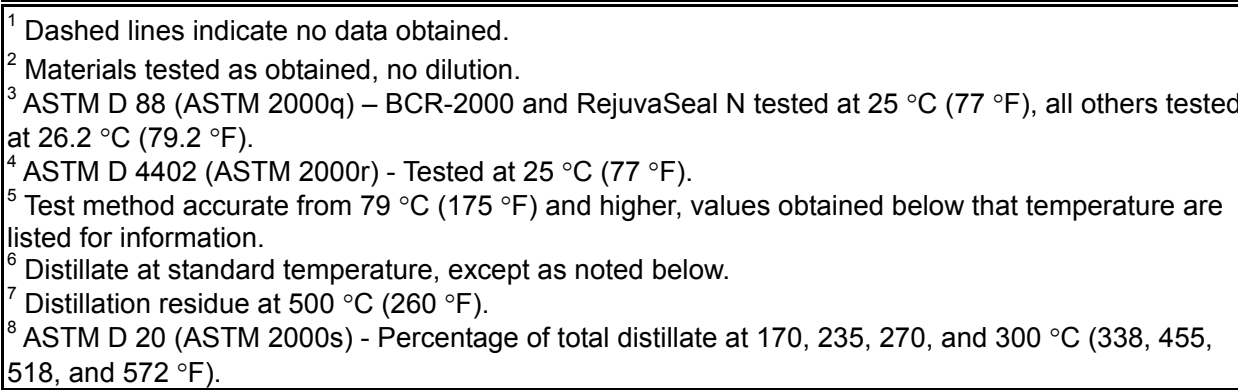 } \\
\hline
\end{tabular}

\begin{tabular}{|c|c|c|c|c|c|c|c|c|c|}
\hline \multicolumn{10}{|c|}{$\begin{array}{l}\text { Table } 23 \\
\text { Results of Tests on Recovered Asphalt of Field Cores from TW } 0 \text { at MacDill AFB }\end{array}$} \\
\hline \multirow[b]{3}{*}{ Material } & \multirow[b]{3}{*}{ Area $^{1}$} & \multirow[b]{3}{*}{$\mid \begin{array}{l}\text { Sec- } \\
\text { tion }^{1,2}\end{array}$} & \multicolumn{7}{|c|}{\begin{tabular}{|c|} 
Surface Asphalt Cement/Top $1 \mathrm{~mm}$ (0.04 in.) Removed; Sampled 2000 (2001) \\
\end{tabular}} \\
\hline & & & \multirow{2}{*}{$\begin{array}{l}\text { Asphalt } \\
\text { Content }^{3} \\
(\%)\end{array}$} & \multirow[b]{2}{*}{$\begin{array}{l}\text { Pene- } \\
\text { tration }^{3}\end{array}$} & \multirow[b]{2}{*}{\begin{tabular}{|l} 
Viscosity \\
(centistokes)
\end{tabular}} & \multicolumn{4}{|c|}{ Dynamic Shear Rheometer ${ }^{3} 60^{\circ} \mathrm{C}\left(140^{\circ} \mathrm{F}\right)$} \\
\hline & & & & & & \begin{tabular}{|l|}
$\begin{array}{l}\text { Phase } \angle \\
\text { (degrees) }\end{array}$ \\
\end{tabular} & cov & $\mathrm{G}^{*}, \mathbf{X} 10^{4}(\mathrm{~Pa})$ & Cov \\
\hline BCR-2000 & 1 & A & \begin{tabular}{ll|l}
5.8 \\
$(6.3 / 5.3)$ \\
\end{tabular} & $11(5 / 8)$ & $\begin{array}{l}3814 \\
(2410 / 2903) \\
\end{array}$ & $\begin{array}{c}53.57 / 56.41 \\
(65.23 / 66.64) \\
\end{array}$ & $\begin{array}{l}4.21 / 1.34 \\
(0.50 / 0.94) \\
\end{array}$ & $\begin{array}{l}55.0 / 30.9 \\
(10.27 / 8.24) \\
\end{array}$ & \begin{tabular}{|l|l|}
$39.5 / 4.04$ \\
$(0.86 / 0.34)$ \\
\end{tabular} \\
\hline BCR-3000 & & $\mathrm{C}$ & $5.4 / 5.0$ & $21 / 14$ & $816 / 1970$ & --- & - & -- & --- \\
\hline $\begin{array}{l}\text { Rejuva- } \\
\text { Seal 50 } \\
\end{array}$ & 2 & A & $5.5(4.6)$ & $15(---)$ & $1024(2404)$ & $\begin{array}{l}61.74 \\
(---/ 68.36) \\
\end{array}$ & \begin{tabular}{|l|}
0.79 \\
$(---/ 0.65)$ \\
\end{tabular} & $\begin{array}{l}25.9 \\
(---/ 6.96) \\
\end{array}$ & \begin{tabular}{|l|}
10.9 \\
$(--/ 0.42)$ \\
\end{tabular} \\
\hline $\begin{array}{l}\text { Rejuva- } \\
\text { Seal N } \\
\end{array}$ & & C & $\begin{array}{l}10.5 \\
(4.8 / 5.0) \\
\end{array}$ & \begin{tabular}{|l|}
21 \\
$(13 / 19)$ \\
\end{tabular} & 1367 & $\begin{array}{l}56.45 \\
(59.88 / 63.33) \\
\end{array}$ & $\begin{array}{l}2.96 \\
(0.36 / 0.31) \\
\end{array}$ & $\begin{array}{l}36.8 \\
(13.13 / 8.06) \\
\end{array}$ & $\begin{array}{l}29.7 \\
(0.05 / 0.27) \\
\end{array}$ \\
\hline \multirow[t]{2}{*}{ Reclamite } & 3 & $A$ & \begin{tabular}{|l|}
$5.3 / 5.5$ \\
$(5.3 / 5.7)$ \\
\end{tabular} & \begin{tabular}{|l|}
$16 / 14$ \\
$(14 / 12)$ \\
\end{tabular} & \begin{tabular}{|l|}
$1761 / 1960$ \\
$(2813 / 2737)$ \\
\end{tabular} & $\begin{array}{l}56.67 / 58.95 \\
(67.21 / 66.98) \\
\end{array}$ & $\begin{array}{l}3.48 / 1.06 \\
(0.21 / 0.41) \\
\end{array}$ & \begin{tabular}{|l|}
$34.8 / 23.1$ \\
$(6.16 / 6.43)$ \\
\end{tabular} & \begin{tabular}{|l|}
$37.3 / 12.4$ \\
$(0.45 / 0.23)$ \\
\end{tabular} \\
\hline & & $B$ & 8.9 & 13 & 2453 & -- & --- & --- & -- \\
\hline GSB-mod & 4 & $A$ & $\begin{array}{l}5.4 / 5.1 \\
(5.3 / 5.1) \\
\end{array}$ & $\begin{array}{l}10 / 9 \\
(8 / 12) \\
\end{array}$ & \begin{tabular}{|l|}
$3574 / 3158$ \\
$(5556 / 6288)$ \\
\end{tabular} & \begin{tabular}{|l|}
$52.78 / 54.40$ \\
$(58.91 / 57.28)$ \\
\end{tabular} & \begin{tabular}{|l}
$3.11 / 0.38$ \\
$(0.39 / 0.26)$ \\
\end{tabular} & \begin{tabular}{|l|}
$58.2 / 42.1$ \\
$(15.6 / 15.0)$ \\
\end{tabular} & \begin{tabular}{|l|}
$36.2 / 5.84$ \\
$(0.06 / 0.06)$ \\
\end{tabular} \\
\hline \multirow[t]{3}{*}{ Uncoated } & 1 & --- & \begin{tabular}{|l|}
5.1 \\
$(5.0 / 5.3)$ \\
\end{tabular} & $11(11 / 7)$ & \begin{tabular}{|l|}
6922 \\
$(18919 / 18628)$ \\
\end{tabular} & $\begin{array}{l}46.15 \\
(59.16 / 58.18) \\
\end{array}$ & $\begin{array}{l}0.56 \\
(0.85 / 0.88) \\
\end{array}$ & $\begin{array}{l}86.8 \\
(15.6 / 18.8) \\
\end{array}$ & \begin{tabular}{|l|}
6.54 \\
$(3.57 / 8.16)$ \\
\end{tabular} \\
\hline & \begin{tabular}{|l|l}
4 \\
\end{tabular} & --- & 5.0 & 15 & 4308 & 49.11 & 0.75 & 74.1 & 7.44 \\
\hline & \multicolumn{2}{|c|}{ Average } & --- & 13 & 5615 & 47.63 & --- & 80.5 & --- \\
\hline
\end{tabular}




\begin{tabular}{|c|c|c|c|c|c|c|c|c|c|}
\hline \multicolumn{10}{|c|}{$\begin{array}{l}\text { Table } 24 \\
\text { Results of Tests on Recovered Asphalt of Field Cores from TW M at MacDill AFB }\end{array}$} \\
\hline \multirow[b]{3}{*}{ Material } & \multirow[b]{3}{*}{ Area $^{1}$} & \multirow[b]{3}{*}{$\begin{array}{l}\text { Sec- } \\
\text { tion }^{1,2}\end{array}$} & \multicolumn{7}{|c|}{\begin{tabular}{|c|c|c|c|} 
Surface Asphalt Cement/Top $1 \mathrm{~mm}$ (0.04 in.) Removed; Sampled 2000 (2001) \\
\end{tabular}} \\
\hline & & & \multirow{2}{*}{$\begin{array}{l}\text { Asphalt } \\
\text { Content }^{3} \\
(\%) \\
\end{array}$} & \multirow[b]{2}{*}{$\begin{array}{l}\text { Pene- } \\
\text { tration }^{3}\end{array}$} & \multirow[b]{2}{*}{$\begin{array}{l}\text { Viscosity, } \\
\text { centistokes }\end{array}$} & \multicolumn{4}{|c|}{ Dynamic Shear Rheometer ${ }^{3} 60^{\circ} \mathrm{C}\left(140^{\circ} \mathrm{F}\right)$} \\
\hline & & & & & & \begin{tabular}{|l|}
$\begin{array}{l}\text { Phase } \angle \\
\text { (degrees) }\end{array}$ \\
\end{tabular} & cov & $\begin{array}{l}\mathrm{G}^{*}, \mathbf{X ~ 1 0 ^ { 4 }} \\
(\mathrm{Pa})\end{array}$ & cov \\
\hline APR-100 & 7 & A & \begin{tabular}{|l|}
$6.6 / 5.9$ \\
$(5.9 / 7.5)$ \\
\end{tabular} & \begin{tabular}{|l|}
$36 / 14$ \\
$(15 / 14)$
\end{tabular} & $\begin{array}{l}936 / 901 \\
(1650 / 2021) \\
\end{array}$ & $\begin{array}{l}65.60 / 66.58 \\
(79.28 / 78.78) \\
\end{array}$ & $\begin{array}{l}2.97 / 4.52 \\
(0.66 / 0.48) \\
\end{array}$ & $\begin{array}{l}22.8 / 17.2 \\
(3.89 / 4.33) \\
\end{array}$ & $\begin{array}{l}35.8 / 47.3 \\
(0.14 / 0.16) \\
\end{array}$ \\
\hline CBRT-SO & 8 & A & $\begin{array}{l}6.6 / 6.1 \\
(6.0 / 5.9)\end{array}$ & \begin{tabular}{|l|}
$13 / 19$ \\
$(22 / 15)$
\end{tabular} & $\begin{array}{l}1925 / 1413 \\
(1121 / 1700)\end{array}$ & $\begin{array}{l}67.01 / 67.05 \\
(83.95 / 87.75)\end{array}$ & $\begin{array}{l}0.49 / 3.05 \\
(3.50 / 0.55)\end{array}$ & $\begin{array}{l}16.0 / 27.2 \\
(2.95 / 2.43)\end{array}$ & $\begin{array}{l}6.63 / 41.9 \\
(13.8 / 2.26)\end{array}$ \\
\hline CPR & 10 & A & $(5.7 / 6.2)$ & $(13 / 17)$ & $(2380 / 1818)$ & --- & --- & --- & --- \\
\hline \multirow[t]{3}{*}{ Uncoated } & 7 & --- & 5.6 & 9 & 3490 & --- & --- & \begin{tabular}{|l|}
--- \\
\end{tabular} & --- \\
\hline & 8 & --- & $5.3(5.3)$ & $13(15)$ & $3909(2526)$ & 58.95 & 0.70 & 40.2 & 10.9 \\
\hline & \multicolumn{2}{|c|}{\begin{tabular}{|l|} 
Average \\
\end{tabular}} & --- & $11(---)$ & 3700 & --- & \begin{tabular}{|l|}
--- \\
\end{tabular} & \begin{tabular}{|l|}
--- \\
\end{tabular} & --- \\
\hline
\end{tabular}

\begin{tabular}{|c|c|c|c|c|c|c|c|c|c|}
\hline \multicolumn{10}{|l|}{\begin{tabular}{|l} 
Table 25 \\
Results 0
\end{tabular}} \\
\hline \multirow[b]{3}{*}{ Material } & \multirow[b]{3}{*}{ Area $^{1}$} & \multirow[b]{3}{*}{$\begin{array}{l}\text { Sec- } \\
\text { tion }^{1,2}\end{array}$} & \multicolumn{7}{|c|}{ Surface Asphalt Cement/Top 1 mm (0.04 in.) Removed; Sampled 2000 (2001) } \\
\hline & & & \multirow{2}{*}{$\begin{array}{l}\text { Asphalt } \\
\text { Content }^{3} \\
(\%)\end{array}$} & \multirow[b]{2}{*}{\begin{tabular}{|l} 
Pene- \\
tration
\end{tabular}} & \multirow[b]{2}{*}{$\begin{array}{l}\text { Viscosity } \\
\text { (centistokes) }\end{array}$} & \multicolumn{4}{|c|}{ Dynamic Shear Rheometer ${ }^{3} 60^{\circ} \mathrm{C}\left(140^{\circ} \mathrm{F}\right)$} \\
\hline & & & & & & $\begin{array}{l}\text { Phase } \angle \\
\text { (degrees) }\end{array}$ & Cov & $\begin{array}{l}\mathrm{G}^{*}, \times 10^{4} \\
(\mathrm{~Pa})\end{array}$ & cov \\
\hline \multirow{2}{*}{ GSB-mod } & \multirow[t]{2}{*}{1} & C & 5.6 & 10 & 2461 & --- & --- & --- & --- \\
\hline & & $\mathrm{D}$ & $\begin{array}{l}5.6 / 5.6 \\
(5.4 / 5.4)\end{array}$ & $11 / 8(9 / 9)$ & $\begin{array}{l}759 / 3193 \\
(4414 / 1169)\end{array}$ & $56.03 / 58.18$ & $1.39 / 1.21$ & $74.8 / 63.6$ & $15.2 / 18.2$ \\
\hline \multirow[t]{2}{*}{$\begin{array}{l}\text { Rejuva-Seal } \\
\mathrm{N}\end{array}$} & \multirow[t]{4}{*}{2} & B & $\begin{array}{l}7.5 / 5.4 \\
(5.4 / 5.8) \\
\end{array}$ & $11 / 11(9 / 13)$ & $\begin{array}{l}1588 / 1464 \\
(2571 / 1572)\end{array}$ & \begin{tabular}{|l|}
$65.82 / 61.67$ \\
$(72.42 / 80.14)$ \\
\end{tabular} & $\begin{array}{l}0.70 / 2.97 \\
(0.34 / 0.86) \\
\end{array}$ & \begin{tabular}{|l|}
$13.4 / 31.9$ \\
$(6.92 / 3.95)$ \\
\end{tabular} & $\begin{array}{l}6.92 / 40.5 \\
(1.63 / 5.56) \\
\end{array}$ \\
\hline & & $\mathrm{F}$ & $7.5 / 5.5$ & $8 / 16$ & $2282 / 1681$ & --- & -- & --- & -- \\
\hline & & C & $5.4(5.4)$ & $15(15)$ & $1802(1166)$ & 61.47 & 0.89 & 46.8 & 12.6 \\
\hline BCR-2000 & & $\mathrm{E}$ & 6.3 & 15 & 1091 & & & & \\
\hline \multirow[t]{2}{*}{ Reclamite } & \multirow[t]{2}{*}{3} & $A$ & $\begin{array}{l}5.5 / 4.5 \\
(5.4 / 5.2)\end{array}$ & $6 / 11(30 / 25)$ & $\begin{array}{l}2763 / 1572 \\
(891 / 1135)\end{array}$ & \begin{tabular}{|l|}
$60.46 / 58.93$ \\
$(---5 / 87.33)$
\end{tabular} & $\begin{array}{l}1.46 / 4.95 \\
(---/ 2.21)\end{array}$ & $\begin{array}{l}26.1 / 34.3 \\
(---5 / 2.47)\end{array}$ & $\begin{array}{l}19.6 / 76.8 \\
(---/ 10.48)\end{array}$ \\
\hline & & $\mathrm{D}$ & 5.6 & 9 & 1839 & --- & \begin{tabular}{|l|l|}
1 & 12.211 \\
--
\end{tabular} & \begin{tabular}{|l|l|}
1 & 12.71 \\
--
\end{tabular} & |- \\
\hline CBTR-SO & \multirow[t]{2}{*}{4} & $\mathrm{~B}$ & \begin{tabular}{|l|}
$5.6 / 5.8$ \\
$(5.7 / 5.8)$
\end{tabular} & $21 / 8(9 / 8)$ & \begin{tabular}{|l|}
$1171 / 1864$ \\
$(2075 / 1952)$
\end{tabular} & $\begin{array}{l}59.63 / 63.14 \\
(65.50 / 79.32)\end{array}$ & \begin{tabular}{|l|}
$7.70 / 3.52$ \\
$(0.78 / 0.84)$
\end{tabular} & $\begin{array}{l}45.9 / 45.2 \\
(9.95 / 4.71)\end{array}$ & $\begin{array}{l}62.1 / 52.6 \\
(6.36 / 6.67)\end{array}$ \\
\hline CPR & & $E$ & $(5.2 / 5.4)$ & $(7 / 9)$ & $(3069 / 2796)$ & --- & -- & -- & -- \\
\hline $\begin{array}{l}\text { Reuva-Seal } \\
500\end{array}$ & \multirow[t]{4}{*}{5} & A & $5.4(5.7)$ & $14(15)$ & 1061 (1918) & 64.1 & 1.68 & 28.8 & 20.4 \\
\hline BCR-3000 & & $\mathrm{B}$ & 5.2 & 7 & 1381 & --- & --- & - & -- \\
\hline \multirow[t]{2}{*}{ AR-2000 } & & \begin{tabular}{|l}
$\mathrm{C}$ \\
\end{tabular} & \begin{tabular}{|l|}
$6.0 / 5.4$ \\
$(6.2 / 6.0)$
\end{tabular} & $5 / 6(8 / 15)$ & $\begin{array}{l}1281 / 2234 \\
(1331 / 879)\end{array}$ & --- & --- & -- & -- \\
\hline & & $D$ & 5.6 & 10 & 1069 & --- & --- & -- & -- \\
\hline APR-100 & 6 & $B$ & $5.3(5.5 / 5.5)$ & $\begin{array}{l}10 / 11 \\
(---4 / 12)\end{array}$ & $\begin{array}{l}2062 / 2203 \\
(3432 / 2415)\end{array}$ & $\begin{array}{l}60.98 / 61.53 \\
(65.85 / 76.44)\end{array}$ & $\begin{array}{l}0.33 / 2.22 \\
(0.49 / 0.10)\end{array}$ & $\begin{array}{l}37.7 / 47.5 \\
(9.64 / 4.01)\end{array}$ & $\begin{array}{l}3.75 / 26.0 \\
(2.91 / 0.75)\end{array}$ \\
\hline \multirow[t]{6}{*}{ Uncoated } & 1 & --- & 5.3 & 16 & 1876 & 52.50 & 0.29 & 12.9 & 4.28 \\
\hline & 2 & - & $5.5(5.2)$ & $8(10)$ & $2815(3733)$ & 59.23 & 0.67 & 52.1 & 8.81 \\
\hline & 3 & -- & $4.9(4.7 / 4.9)$ & $5\left(--{ }^{4} / 10\right)$ & $\begin{array}{l}1952 \\
(16,494 / 3339)\end{array}$ & $\begin{array}{l}62.95 \\
(64.73 / 70.49)\end{array}$ & \begin{tabular}{|l|}
2.33 \\
$(0.70 / 2.69)$
\end{tabular} & $\begin{array}{l}36.1 \\
(14.3 / 9.21)\end{array}$ & $\begin{array}{l}29.0 \\
(6.29 / 24.87)\end{array}$ \\
\hline & 4 & - & 5.3 & 10 & 3529 & 54.91 & 0.40 & 55.0 & 5.60 \\
\hline & 5 & -- & 5.0 & 12 & 3954 & 57.41 & 2.45 & 52.4 & 47.0 \\
\hline & \multicolumn{2}{|c|}{\begin{tabular}{|l|} 
\\
Average \\
\end{tabular}} & --- & 10.2 & 2825 & 57.40 & 6.99 & 41.7 & 42.6 \\
\hline \multicolumn{10}{|c|}{ 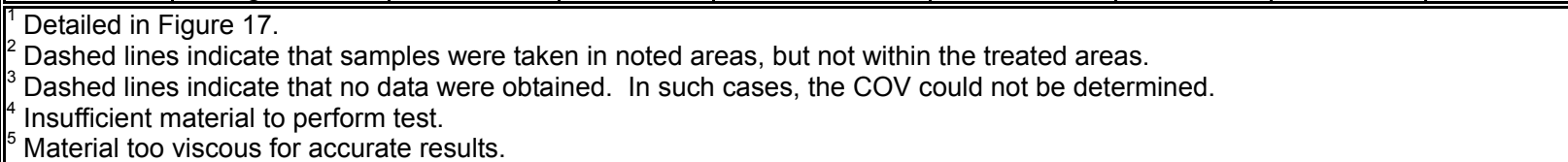 } \\
\hline
\end{tabular}




\section{Fuel-resistance results}

Tables 26 and 27 list the material tested and the results of the laboratory testing for fuel resistance. All of the nonpetroleum-based materials passed the fuelresistance test, and the fuel did not affect the surfaces of the core specimens.

\begin{tabular}{|c|c|c|c|c|c|c|c|}
\hline \multicolumn{8}{|c|}{$\begin{array}{l}\text { Table } 26 \\
\text { Results of Fuel-Resistance Tests on Field Cores from MacDill AFB }\end{array}$} \\
\hline \multirow[b]{2}{*}{ Material Type } & \multirow[b]{2}{*}{ Taxiway } & \multirow[b]{2}{*}{ Area $^{1}$} & \multirow[b]{2}{*}{ Section $^{1}$} & \multicolumn{3}{|c|}{$\begin{array}{l}\text { Change in Fuel Depth, mm (in.) } \\
\end{array}$} & \multirow{2}{*}{$\begin{array}{l}\text { Test } \\
\text { Result }^{2}\end{array}$} \\
\hline & & & & $5 \mathrm{~min}$ & $15 \mathrm{~min}$ & $30 \mathrm{~min}$ & \\
\hline BCR-2000 & \multirow[t]{4}{*}{$\mathrm{O}$} & \multirow[t]{2}{*}{1} & A & $0.00(0.00)$ & $0.25(0.01)$ & $0.25(0.01)$ & Passed \\
\hline BCR-3000 & & & $\mathrm{C}$ & $0.00(0.00)$ & $0.51(0.02)$ & $0.51(0.02)$ & Passed \\
\hline RejuvaSeal 50 & & \multirow[t]{2}{*}{2} & A & $0.00(0.00)$ & $0.51(0.02)$ & $0.76(0.03)$ & Passed \\
\hline RejuvaSeal N & & & $\mathrm{C}$ & $0.00(0.00)$ & $1.02(0.04)$ & $1.52(0.06)$ & Passed \\
\hline CBRT-SO & \multirow[t]{2}{*}{$\mathrm{M}$} & 8 & A & $0.76(0.03)$ & $1.02(0.04)$ & $1.27(0.05)$ & Passed \\
\hline PolyTar & & 5 & $\mathrm{~A}$ & $0.00(0.00)$ & $0.51(0.02)$ & $0.76(0.03)$ & \begin{tabular}{|l|} 
Passed \\
\end{tabular} \\
\hline
\end{tabular}

\begin{tabular}{|c|c|c|c|c|c|c|c|}
\hline \multirow{2}{*}{$\begin{array}{l}\text { Material } \\
\text { Type }\end{array}$} & \multirow[b]{2}{*}{ Taxiway } & \multirow[b]{2}{*}{ Area- } & \multirow[b]{2}{*}{ Section ${ }^{1}$} & \multicolumn{3}{|c|}{ "Change in Fuel Depth, mm (in.) } & \multirow{2}{*}{$\begin{array}{l}\text { Test } \\
\text { Result }^{2}\end{array}$} \\
\hline & & & & $5 \mathrm{~min}$ & $15 \min$ & $30 \mathrm{~min}$ & \\
\hline BCR-2000 & \multirow[t]{6}{*}{$\overline{L L}$} & 2 & $\mathrm{E}$ & $0.00(0.00)$ & $0.00(0.00)$ & $0.00(0.00)$ & Passed \\
\hline BCR-3000 & & 5 & $\mathrm{~B}$ & $0.00(0.00)$ & $0.00(0.00)$ & $0.00(0.00)$ & Passed \\
\hline CBRT-SO & & 4 & $\mathrm{~B}$ & $0.00(0.00)$ & $0.51(0.02)$ & $0.76(0.03)$ & Passed \\
\hline AR-2000 & & 5 & $\mathrm{D}$ & $0.00(0.00)$ & $0.00(0.00)$ & $0.00(0.00)$ & Passed \\
\hline RejuvaSeal N & & 2 & $\mathrm{~B}$ & $0.00(0.00)$ & $0.51(0.02)$ & $0.76(0.03)$ & Passed \\
\hline PolyTar & & 4 & A & $0.00(0.00)$ & $0.51(0.02)$ & $0.76(0.03)$ & Passed \\
\hline
\end{tabular}

\section{Aging evaluation results}

The results of the DSR testing for the aging evaluation are shown in Tables 28 and 29 for samples aged with one PAV cycle. Tables 30 and 31 provide the results for samples aged with two PAV cycles. The asphalt binder in Tables 28 and 30 had $0.158 \mathrm{~L} / \mathrm{m}^{2}(0.05$ gsy) of the listed rejuvenator blended with it prior to testing. The asphalt binder in Tables 29 and 31 had $0.316 \mathrm{~L} / \mathrm{m}^{2}$ (0.10 gsy) of the listed rejuvenator blended with it prior to testing. DSR testing on asphalt cements with $0.158 \mathrm{~L} / \mathrm{m}^{2}$ (0.05 gsy) rejuvenator added after aging with one PAV cycle could be evaluated at all selected temperatures except for the APR-100 material. This material was too viscous (soft) at temperatures above $19{ }^{\circ} \mathrm{C}\left(66^{\circ} \mathrm{F}\right)$ for the established test parameters, Tables 28 and 30 . The test mixtures, rejuvenated at the rate of $0.316 \mathrm{~L} / \mathrm{m}^{2}(0.10$ gsy) and aged with one PAV cycle, could be tested for all samples except for Reclamite at $31^{\circ} \mathrm{C}\left(88^{\circ} \mathrm{F}\right)$ and RejuvaSeal $\mathrm{N}$ at 27 and $31^{\circ} \mathrm{C}\left(81\right.$ and $\left.88^{\circ} \mathrm{F}\right)$, Table 29 . At a rate of $0.316 \mathrm{~L} / \mathrm{m}^{2}$ (0.10 gsy) and aged with two PAV cycles, only GSB-mod and Reclamite could be tested at all temperatures with the established test parameters. The COV determined for each test showed that the variation in results obtained for the $\mathrm{G}^{*}$ 


\begin{tabular}{|c|c|c|c|c|c|c|}
\hline \multicolumn{7}{|c|}{$\begin{array}{l}\text { Table } 28 \\
\text { Results of Artificially Aged (One PAV Cycle) Asphalt Cement with } \\
0.158 \mathrm{~L} / \mathrm{m}^{2} \text { (0.05 gsy) of Rejuvenator Added }\end{array}$} \\
\hline \multirow[b]{2}{*}{ Material } & \multirow{2}{*}{$\begin{array}{l}\text { Test Temperature } \\
\left({ }^{\circ} \mathrm{C}\right)\end{array}$} & \multicolumn{2}{|c|}{$\delta$ (Degrees) } & \multicolumn{2}{|c|}{$\begin{array}{l}\mathbf{G}^{*}(\mathrm{kPa}) \\
\end{array}$} & \multirow[b]{2}{*}{$\mathbf{G}^{*} \sin \delta(\mathrm{kPa})$} \\
\hline & & Mean & Cov & Mean & COV & \\
\hline \multirow[t]{5}{*}{ Untreated } & 19 & 444.01 & 5.18 & $1212,370.0$ & 19.34 & 8594.5 \\
\hline & 22 & 44.49 & 4.52 & $11,240.0$ & 17.26 & 7876.8 \\
\hline & 25 & 46.65 & 4.09 & $8,702.0$ & 15.69 & 6327.9 \\
\hline & 28 & 49.42 & 3.60 & $6,236.0$ & 14.36 & 4736.2 \\
\hline & 31 & 52.55 & 3.03 & $4,268.0$ & 12.88 & 3388.3 \\
\hline APR-100 & 19 & 74.65 & 2.38 & 229.3 & 28.42 & 221.1 \\
\hline \multirow[t]{5}{*}{ CBRT-SO } & 19 & 62.39 & 3.53 & 503.8 & 4.34 & 446.4 \\
\hline & 22 & 66.83 & 0.23 & 315.0 & 6.64 & 289.6 \\
\hline & 25 & 70.76 & 1.61 & 190.0 & 6.72 & 179.4 \\
\hline & 27 & 73.02 & 1.18 & 134.0 & 7.36 & 128.2 \\
\hline & 31 & 77.12 & 0.78 & 63.9 & 5.99 & 62.3 \\
\hline \multirow[t]{5}{*}{ GSB-mod } & 19 & 50.82 & 2.63 & $6,902.0$ & 14.78 & 5350.2 \\
\hline & 22 & 51.51 & 2.24 & $6,091.0$ & 14.07 & 4767.5 \\
\hline & 25 & 53.77 & 2.01 & $4,499.0$ & 13.65 & 3629.1 \\
\hline & 28 & 56.59 & 1.88 & $3,091.0$ & 13.66 & 2580.2 \\
\hline & 31 & 59.69 & 1.64 & $2,017.0$ & 13.89 & 1741.3 \\
\hline \multirow[t]{5}{*}{ Reclamite } & 19 & 60.62 & 2.46 & $2,742.5$ & 15.00 & 2742.5 \\
\hline & 22 & 61.40 & 2.25 & $2,351.0$ & 17.24 & 2351.0 \\
\hline & 25 & 63.74 & 2.02 & $1,660.0$ & 16.73 & 1660.0 \\
\hline & 28 & 66.54 & 1.74 & $1,081.0$ & 16.19 & 1081.0 \\
\hline & 31 & 69.51 & 1.53 & 672.9 & 16.03 & 672.9 \\
\hline \multirow[t]{5}{*}{ RejuvaSeal N } & 19 & 76.23 & 1.47 & 76.23 & 20.52 & 76.2 \\
\hline & 22 & 77.57 & 1.11 & 50.43 & 18.62 & 50.4 \\
\hline & 25 & 79.19 & 0.51 & 31.63 & 16.82 & 31.6 \\
\hline & 27 & 80.04 & 0.55 & 22.75 & 13.75 & 22.8 \\
\hline & 31 & 81.97 & 0.36 & 11.68 & 11.40 & 11.7 \\
\hline
\end{tabular}

\begin{tabular}{|c|c|c|c|c|c|c|}
\hline \multicolumn{7}{|c|}{$\begin{array}{l}\text { Table } 29 \\
\text { Results of Artificially Aged (One PAV Cycle) Asphalt Cement with } \\
0.316 \mathrm{~L} / \mathrm{m}^{2} \text { (0.10 gsy) Rejuvenator Added }\end{array}$} \\
\hline \multirow[b]{2}{*}{ Material } & \multirow{2}{*}{$\begin{array}{l}\text { Test Temperature } \\
\left({ }^{\circ} \mathrm{C}\right)\end{array}$} & \multicolumn{2}{|c|}{$\delta$ (Degrees) } & \multicolumn{2}{|c|}{$\mathrm{G}^{*}(\mathrm{kPa})$} & \multirow{2}{*}{$\begin{array}{l}G^{*} \sin \delta \\
(\mathrm{kPa})\end{array}$} \\
\hline & & Mean & COV & Mean & COV & \\
\hline \multirow[t]{5}{*}{ APR-100 } & 19 & 83.04 & 1.18 & 10.78 & 27.46 & $\begin{array}{r}16.7 \\
\end{array}$ \\
\hline & 22 & 83.80 & 1.14 & 10.86 & 25.77 & 10.8 \\
\hline & 25 & 84.68 & 1.04 & 6.79 & 23.45 & 6.8 \\
\hline & 27 & 85.47 & 0.89 & 4.83 & 20.77 & 4.8 \\
\hline & 31 & 87.26 & 0.52 & 2.48 & 16.14 & 2.5 \\
\hline \multirow[t]{5}{*}{ CBRT-SO } & 19 & 77.45 & 0.86 & 38.21 & 13.78 & 37.3 \\
\hline & 22 & 78.45 & 1.35 & 25.25 & 13.80 & 24.7 \\
\hline & 25 & 79.48 & 1.47 & 16.32 & 12.57 & 16.0 \\
\hline & 27 & 80.02 & 1.60 & 12.20 & 13.13 & 12.0 \\
\hline & 31 & 82.18 & 1.41 & 6.40 & 12.93 & 6.3 \\
\hline \multirow[t]{5}{*}{ GSB-mod } & 19 & 54.35 & 2.92 & $4,630.0$ & 21.43 & 3762.3 \\
\hline & 22 & 55.32 & 2.64 & $3,901.0$ & 20.20 & 3208.0 \\
\hline & 25 & 57.57 & 2.25 & $2,816.0$ & 19.07 & 2376.8 \\
\hline & 28 & 60.21 & 1.91 & $1,895.0$ & 18.25 & 1644.6 \\
\hline & 31 & 62.99 & 1.62 & $1,222.0$ & 17.59 & 1088.7 \\
\hline \multirow[t]{4}{*}{ Reclamite } & 19 & 70.27 & 1.15 & 769.3 & 18.30 & 724.1 \\
\hline & 22 & 71.18 & 1.16 & 639.1 & 17.76 & 604.9 \\
\hline & 25 & 73.28 & 1.17 & 427.2 & 18.83 & 409.1 \\
\hline & 28 & 76.64 & 2.46 & 216.8 & 46.46 & 210.9 \\
\hline \multirow[t]{3}{*}{ RejuvaSeal N } & 19 & 88.02 & 0.62 & 1.603 & 20.52 & 1.6 \\
\hline & 22 & 88.83 & 0.60 & 1.093 & 18.62 & 1.1 \\
\hline & 25 & 89.71 & 0.19 & 0.738 & 16.82 & 0.7 \\
\hline
\end{tabular}




\begin{tabular}{|c|c|c|c|c|c|c|}
\hline \multicolumn{7}{|c|}{$\begin{array}{l}\text { Table } 30 \\
\text { Results of Artificially Aged (Two PAV Cycles) Asphalt Cement with } \\
0.158 \mathrm{~L} / \mathrm{m}^{2} \text { (0.05 gsy) of Rejuvenator Added }\end{array}$} \\
\hline \multirow[b]{2}{*}{ Material } & \multirow{2}{*}{$\begin{array}{l}\text { Test Temperature } \\
\left({ }^{\circ} \mathrm{C}\right)\end{array}$} & \multicolumn{2}{|c|}{$\begin{array}{ll}\delta \text { (Degrees) } \\
\end{array}$} & \multicolumn{2}{|c|}{ " $\mathrm{G}^{*}(\mathrm{kPa})$} & \multirow[b]{2}{*}{$\mathrm{G}^{*} \sin \delta(\mathrm{kPa})$} \\
\hline & & Mean & cov & Mean & cov & \\
\hline \multirow[t]{5}{*}{ Untreated } & 19 & 36.72 & 3.78 & $21,465.0$ & 16.57 & $3035,900.4$ \\
\hline & 22 & 37.50 & 3.98 & $19,617.5$ & 18.20 & $32,225.3$ \\
\hline & 25 & 39.23 & 3.50 & $15,960.0$ & 18.99 & $25,235.8$ \\
\hline & 28 & 41.67 & 3.10 & $12,010.0$ & 18.77 & $18,064.5$ \\
\hline & 31 & 44.45 & 2.52 & $8,532.5$ & 18.04 & $12,184.3$ \\
\hline \multirow[t]{5}{*}{ APR-100 } & 19 & 54.93 & 0.31 & 2,160 & 2.72 & $1,767.9$ \\
\hline & 22 & 57.48 & 0.24 & 1,510 & 4.22 & $1,273.2$ \\
\hline & 25 & 60.85 & 0.26 & 910 & 4.67 & 794.7 \\
\hline & 27 & 64.89 & 0.22 & 501 & 5.49 & 453.7 \\
\hline & 31 & 69.40 & 0.55 & 247 & 10.38 & 231.2 \\
\hline \multirow[t]{5}{*}{ CBRT-SO } & 19 & 48.72 & 0.90 & 2,383 & 10.23 & $1,790.8$ \\
\hline & 22 & 52.49 & 1.09 & 1,590 & 11.55 & $1,261.3$ \\
\hline & 25 & 57.20 & 1.19 & 904 & 11.38 & 759.9 \\
\hline & 27 & 63.20 & 1.10 & 449 & 11.36 & 400.8 \\
\hline & 31 & 73.39 & 1.30 & 192 & 13.87 & 184.0 \\
\hline \multirow[t]{5}{*}{ GSB-mod } & 19 & 37.80 & 1.16 & 16,700 & 1.73 & $10,235.5$ \\
\hline & 22 & 39.99 & 0.56 & 12,600 & 1.37 & $8,097.4$ \\
\hline & 25 & 43.38 & 0.54 & 8,300 & 1.46 & $5,700.7$ \\
\hline & 28 & 47.26 & 0.39 & 5,060 & 2.11 & $3,716.3$ \\
\hline & 31 & 51.36 & 0.07 & 2,960 & 2.38 & $2,312.0$ \\
\hline \multirow[t]{5}{*}{ Reclamite } & 19 & 46.04 & 0.62 & 7,720 & 4.29 & $5,557.0$ \\
\hline & 22 & 48.73 & 0.36 & 5,450 & 2.84 & $4,096.3$ \\
\hline & 25 & 52.54 & 0.36 & 3,350 & 2.43 & $2,659.2$ \\
\hline & 28 & 56.82 & 0.36 & 1,900 & 2.65 & $1,590.2$ \\
\hline & 31 & 61.22 & 0.33 & 1,023 & 2.51 & 896.6 \\
\hline \multirow[t]{5}{*}{ RejuvaSeal N } & 19 & 50.26 & 2.64 & 1,760 & 9.08 & $1,353.4$ \\
\hline & 22 & 54.70 & 1.99 & 1,100 & 7.44 & 897.8 \\
\hline & 25 & 59.71 & 1.27 & 610 & 7.00 & 526.7 \\
\hline & 28 & 66.08 & 1.00 & 290 & 8.28 & 265.1 \\
\hline & 31 & 77.22 & $--^{1}$ & 58.8 & $--^{-1}$ & 57.3 \\
\hline
\end{tabular}

values was much greater than those obtained for the phase angle. In many cases, this variation was large enough to affect the accuracy of the $G^{*} \sin \delta$ values reported in the tables.

The test data show that all the rejuvenator materials used in the test provided rejuvenation, increased the phase angle, and decreased $\mathrm{G}^{*} \sin \delta$. Comparing Tables 28 to 29 and 30 to 31 shows that the PAV procedure does result in the aging or hardening of asphalt binder. Increases in the amount of rejuvenator added to the binder resulted in an increased phase angle and a decreased $G^{*} \sin \delta$. The phase angle results from this testing were plotted to better illustrate the effect of the rejuvenators on the asphalt binder. The phase angle was selected over the $\mathrm{G}^{*}$ or $\mathrm{G}^{*} \sin \delta$ parameters because of the COV values as discussed in the previous paragraph. Figure 36 gives the phase angle value results for an application rate of $0.158 \mathrm{~L} / \mathrm{m}^{2}$ (0.05 gsy) to asphalt cements that were aged with one and two cycles in a PAV. Figure 37 gives the phase angle results for an application rate of $0.316 \mathrm{~L} / \mathrm{m}^{2}$ (0.10 gsy). The figures illustrate that, as expected, an increase in temperature results in an increased phase angle. The figures show that as the test 


\begin{tabular}{|c|c|c|c|c|c|c|}
\hline $\begin{array}{l}\text { Table } 31 \\
\text { Results of } \\
0.316 \mathrm{~L} / \mathrm{m}\end{array}$ & $\begin{array}{l}\text { Artificially Age } \\
\text { (0.10 gsy) Reju }\end{array}$ & $\begin{array}{l}\text { (Two } \\
\text { venat }\end{array}$ & $\begin{array}{l}\text { AV C } \\
\text { Adde }\end{array}$ & les) As & nalt C & nent with \\
\hline & Test Temperature & $\delta \quad \delta(\mathbf{D}$ & rees) & $\mathbf{G}^{*}$ & Pa) & \\
\hline Material & $\left({ }^{\circ} \mathrm{C}\right)$ & Mean & $\mathrm{COV}^{1}$ & Mean & $\mathrm{COV}^{1}$ & $\mathbf{G}^{*} \sin \delta(\mathrm{kPa})$ \\
\hline APR-100 & 19 & "65.15 & 0.58 & 461 & 7.26 & 418.3 \\
\hline & 22 & 69.44 & 0.72 & 260 & 8.47 & 243.4 \\
\hline & 25 & $--^{2}$ & --- & --- & --- & --- \\
\hline CBRT-SO & 19 & 58.58 & 2.44 & 459 & 25.07 & 391.7 \\
\hline & 22 & $84.31^{3}$ & 4.40 & $55.2^{3}$ & 31.93 & 54.9 \\
\hline & 25 & --- & --- & --- & --- & --- \\
\hline GSB-mod & 19 & 40.93 & 2.25 & 9,410 & 4.31 & $6,164.8$ \\
\hline & 22 & 42.94 & 0.68 & 7,230 & 9.08 & $4,925.3$ \\
\hline & 25 & 45.91 & 0.58 & 4,860 & 12.96 & $3,490.7$ \\
\hline & 28 & 49.58 & 0.92 & 2,950 & 13.59 & $2,245.9$ \\
\hline & 31 & 53.33 & 1.10 & 1,710 & 14.93 & $1,371.6$ \\
\hline Reclamite & 19 & 55.61 & 1.24 & 2,600 & 6.26 & $2,145.6$ \\
\hline & 22 & 58.29 & 0.57 & 1,750 & 5.80 & $1,488.8$ \\
\hline & 25 & 62.18 & 0.47 & 1,007 & 5.76 & 890.6 \\
\hline & 28 & 66.47 & 0.14 & 530 & 6.76 & 485.9 \\
\hline & 31 & 70.96 & 0.04 & 260 & 7.55 & 245.8 \\
\hline RejuvaSeal N & 19 & 68.22 & 2.17 & 1,386 & 23.06 & $1,287.1$ \\
\hline & 22 & --- & --- & --- & --- & \\
\hline
\end{tabular}

temperature increased, especially for the asphalts given two cycles in the PAV, the phase angle of the coal-tar based materials increased more rapidly (greater slope) than the asphalt-based materials. This was not unexpected, since coal tars cure and age mainly through evaporation, and the PAV would therefore not be expected to have as great an effect on curing them as it does with asphalt materials (Shoenberger 2001).

\section{Seal coat cohesive/adhesive results}

Table 32 lists the type of failure and the force required to pull the dolly from the surface for the various seal coats tested. Not all the seal coats evaluated in this study could be tested for their adhesive/cohesive properties. To run the test procedure, a sealed surface must have sufficient in-place thickness to allow the dolly to be attached to it. This requirement limited the testing to those materials listed in Table 32. The various values given for coal-tar sealers indicate the range of values and the effect of temperature changes on values obtained.

\section{Rejuvenator and Seal Coat Performance Summary}

\section{General}

The results reported herein are based on field and laboratory evaluation and on information provided by the various material manufacturers. A fact sheet containing detailed information on each material is provided in Appendix A. 


\begin{tabular}{|c|c|c|c|}
\hline \multicolumn{4}{|c|}{$\begin{array}{l}\text { Table } 32 \\
\text { Tensile/Cohesive Strength of Seal Coat Mixtures }\end{array}$} \\
\hline Mixture & $\begin{array}{l}\text { Test Temperature } \\
{ }^{\circ} \mathrm{C}\left({ }^{\circ} \mathrm{F}\right)\end{array}$ & Type of Failure ${ }^{1}$ & \begin{tabular}{|l|} 
Pull-Off Strength \\
$\mathrm{kPa}$ (psi)
\end{tabular} \\
\hline Antiskid (Promak A) & $24(75)$ & Cohesive & $1,172(170)^{2}$ \\
\hline LAS-320 & $24(75)$ & Cohesive & $1,448(210)^{2}$ \\
\hline Polytar & $24(75)$ & Adhesive & $1,551(225)^{2}$ \\
\hline Coal-tar sealer & $49(120)$ & Adhesive & $517-776(75-112)^{3}$ \\
\hline \multicolumn{4}{|c|}{$\begin{array}{l}{ }^{1} \text { Cohesive is failure within the mixture itself. Adhesive failure is pulling off or apart from the } \\
\text { surface of the HMA. } \\
{ }^{2} \text { Results based on average of tests. } \\
3 \text { Range of four tests on typical coal-tar mixtures with adhesive failures. }\end{array}$} \\
\hline
\end{tabular}

\section{Rejuvenators}

The recovered asphalt used for evaluation from each section was not obtained nor is it intended to be a representative sample of the entire section. The cores from each treated section were obtained in one arbitrarily selected location. Only cores from untreated areas were obtained in various locations within the designated taxiway area. The DSR tests were not performed on all samples; however, the results of those that were run are included in the following paragraphs.

a. AR-2000: This coal-tar based rejuvenator/sealer left some residual material on the surface. When compared to untreated pavement, this product reduced the viscosity of the recovered asphalt cement and lowered the skid resistance of the pavement during the period of this study.

b. APR-100: This petroleum-based rejuvenator left only a small amount of residual material on the surface. When compared to untreated pavement, this product reduced the viscosity of the recovered asphalt cement, increased the phase angle and lowered the $\mathrm{G}^{*}$ (softened the asphalt), and lowered the skid resistance of the pavement during the period of this study.

c. BCR-2000 and BCR-3000: These coal-tar based rejuvenator/sealers left enough residual material on the surface to retain aggregate. When compared to untreated pavement, this product reduced the viscosity of the recovered asphalt cement, increased the phase angle and lowered the $\mathrm{G}^{*}$ (softened the asphalt), and lowered the skid resistance (less significantly when aggregate was applied) of the pavement during the period of this study.

d. CBRT-SO: This coal-tar based rejuvenator/sealer left enough residual material on the surface to retain aggregate. When compared to untreated pavement, this product reduced the viscosity of the recovered asphalt cement, increased the phase angle and lowered the $\mathrm{G}^{*}$ (softened the asphalt), and lowered the skid resistance (less significantly when aggregate was applied) of the pavement during the period of this study. 
e. $C P R$ : This coal-tar based rejuvenator/sealer left residual material on the surface. Aggregate was not applied to any of the test strips. When compared to untreated pavement, this product reduced the viscosity of the recovered asphalt cement and lowered the skid resistance of the pavement during the period of this study.

f. GSB-mod: This petroleum-based rejuvenator left enough residual material on the surface to retain aggregate. When compared to untreated pavement, this product generally reduced the viscosity of the recovered asphalt cement and increased the phase angle and lowered the $\mathrm{G}^{*}$ (softened the asphalt). The product just slightly lowered the skid resistance (aggregate applied to all sections) of the pavement during the period of this study.

g. Reclamite: This petroleum-based rejuvenator initially left almost no residual material on the surface and visually disappeared within a few months. When compared to untreated pavement, this product reduced the viscosity of the recovered asphalt cement, increased the phase angle and lowered the $\mathrm{G}^{*}$ (softened the asphalt), and lowered the skid resistance of the pavement during the period of this study.

h. RejuvaSeal N, RejuvaSeal 50, and RejuvaSeal 500: These coal-tar based rejuvenator/sealers left enough residual material on the surface to retain aggregate. When compared to untreated pavement, this product reduced the viscosity of the recovered asphalt cement, increased the phase angle and lowered the $\mathrm{G}^{*}$ (softened the asphalt), and lowered the skid resistance (less significantly when aggregate was applied) of the pavement during the period of this study.

\section{Seal coat performance summary}

The evaluation of the performance of seal coat materials is best accomplished through the long-term monitoring of pavement performance. The performance of a relatively thin pavement seal coating is best derived from its long-term effectiveness at protecting the underlying pavement. The seal coat materials evaluated can be placed in final thicknesses varying from almost no additional thickness (less than $1 \mathrm{~mm}(0.04 \mathrm{in}$.) up to $4 \mathrm{~mm}(0.17 \mathrm{in}$.).

a. CRF: This pavement seal coat material appeared to be able to hold the aggregate that was worked into the surface. Visually the CRF material was not noticeable from the untreated pavement within a few months of application. It was placed in a location where skid testing was not performed.

b. LAS-320: This pavement seal coat material was applied to the pavement surface with no aggregate. Ten months after placement the sealer remained black in color. When compared to untreated pavement, this product lowered the skid resistance of the pavement during the period of this study. 
c. PAS: This pavement seal coat material was applied to the pavement surface with no aggregate. One year after placement the sealer remained black in color. When compared to untreated pavement, this product lowered the skid resistance of the pavement during the period of this study.

d. PolyTar: This pavement seal coat material was applied to the pavement surface with no aggregate. One year after placement the sealer remained black in color. When compared to untreated pavement, this product lowered the skid resistance of the pavement during the period of this study.

e. Antiskid (Promak A): This pavement seal coat material was applied to the pavement surface with the use of a very hard, crushed aggregate. One year after placement the sealer remained black in color. When compared to untreated pavement, this product did not lower the skid resistance of the pavement but provided the highest values measured. 


\section{Conclusions and Recommendations}

\section{Conclusions}

\section{General}

The conclusions herein are based upon field and laboratory evaluation of the referenced materials. These are divided into rejuvenator (including rejuvenator/ sealer) and seal coat materials.

\section{Rejuvenator (rejuvenator/sealer)}

The rejuvenator materials used in this study reduced the viscosity of the recovered asphalt cement binder in the treated pavement. Because the sample cores were obtained from the treated and untreated asphalt pavement from various locations arbitrarily selected throughout the taxiways, the results reported cannot be considered a completely adequate statistical sample. Therefore, the values obtained and presented in this study for each material should be considered as an indication and not an absolute measure of performance.

As expected, the application of a rejuvenator, at least in the short term, reduced skid resistance. Several of the materials leave a substantial material residue on the pavement surface, providing a medium to hold sand in place for increased pavement skid resistance. When sand was not applied to these materials, the friction values were low and sometimes below acceptable minimums. Generally, the skid resistance of all the rejuvenated pavement sections increased with time. With the use of correct application rates and, in some instances, the use of sand (for short-term use), the skid resistance of a rejuvenated pavement can be kept above minimum satisfactory levels.

The coal-tar based rejuvenator/sealer product provided a fuel-resistant pavement surface. The effectiveness of long-term fuel resistance depends upon how well the products withstand the effects of traffic.

Based on the results of this study, the use of DSR testing to specify or control the amount or effectiveness of rejuvenating materials is not recommended at this time. The DSR test method does require substantially less material for testing; 
however, current recovery methods normally produce more than sufficient amounts for viscosity testing. If the results from DSR testing were used, the test parameter selected should be the phase angle, since it provided a more statistically consistent result than the $\mathrm{G}^{*}$ parameter.

\section{Seal coat}

The LAS-320, PolyTar, and ANTISKID products exhibited similar tensile strengths. The CRF and PAS products, as they were applied on the test sections, were not thick enough for tensile testing.

The LAS-320, PolyTar, and ANTISKID products all passed field fuelresistance tests. The LAS-320 is an acrylic-based seal coat material. Its longterm fuel resistance effectiveness will depend upon how well the product withstands the effects of traffic. The other two products use a modified coal-tar emulsion and have a history of successful seal coat usage.

The seal coat products evaluated provided satisfactory skid resistance. The skid resistance of the products when aggregate is applied to the surface is dependent upon the amount and type of aggregate. ANTISKID provided the highest skid-resistance level because of the amount of hard, durable, angular aggregate used in the surfacing.

\section{Recommendations}

To better evaluate the performance of both the rejuvenators and seal coat materials, the field sections should be periodically evaluated over the next several years. The guide specification for bituminous rejuvenation (Appendix C) should be used and evaluated in a U.S. Air Force project.

Additional investigation is required for further development of a test method for determining the effectiveness of a rejuvenator. This would involve the development of an effective means of aging both coal-tar- and asphalt-based rejuvenated asphalt cements. The rejuvenator and rejuvenator/sealer products that leave residual material on the pavement surface would require investigation to determine how much and what component of the product enters into the pavement to provide rejuvenation. 


\section{References}

American Society for Testing and Materials. (2000a). "Standard test method for airport pavement condition index surveys," Designation D 5340, Vol 04.03, West Conshohocken, PA.

. (2000b). "Standard test method for measuring surface macrotexture depth using a volumetric technique," Designation E 965, Vol 04.03, West Conshohocken, PA.

. (2000c). "Standard test method for measuring surface frictional properties using the British Pendulum tester," Designation E 303, Vol 04.03, West Conshohocken, PA.

(2000d). "Standard specification for special purpose, smooth-tread tire, operated on fixed braking slip continuous friction measuring equipment," Designation E 1551, Vol 04.03, West Conshohocken, PA.

. (2000e). "Standard test methods for emulsified bitumens used as protective coatings," Designation D 2939, Vol 04.04, West Conshohocken, PA.

. (2000f). "Standard test methods for quantitative extraction of bitumen from bituminous paving mixtures," Designation D 2172, Vol 04.03, West Conshohocken, PA.

. (2000g). "Standard test method for recovery of asphalt from solution by abson method," Designation D 1856, Vol 04.03, West Conshohocken, PA.

. (2000h). "Standard test method for penetration of bituminous materials," Designation D 5, Vol 04.03, West Conshohocken, PA.

. (2000i). "Standard test method for kinematic viscosity of asphalts (bitumens)," Designation D 2170, Vol 04.03, West Conshohocken, PA.

. (2000j). "Proposed test method for determining the rheological properties of asphalt binder for specification purposes using a dynamic shear rheometer (DSR)," Designation P 246, Vol 04.03, West Conshohocken, PA. 
American Society for Testing and Materials. (2000k). "Standard specification for viscosity-graded asphalt cement for use in pavement construction," Designation D 3381, Vol 04.03, West Conshohocken, PA.

. (20001). "Standard specification for performance graded asphalt binder," Designation D 6373, Vol 04.03, West Conshohocken, PA.

. (2000m). "Standard practice for accelerated aging of asphalt binder using a pressurized aging vessel (PVA)," Designation D 6521, Vol 04.03, West Conshohocken, PA.

. (2000n). "Standard test method for pull-off strength of coatings using portable adhesion testers," Designation D 4541, Volume 06.02, West Conshohocken, PA.

. (2000o). "Test methods and practices for emulsified asphalts," Designation D 244, Vol 04.03, West Conshohocken, PA.

. (2000p). "Test method for flash and fire points by Cleveland open cup,” Designation D 92, Vol 05.01, West Conshohocken, PA.

. (2000q). "Test method for saybolt viscosity," Designation D 88, Vol 04.04, West Conshohocken, PA.

. (2000r). "Test method for viscosity determinations of unfilled asphalts using the Brookfield thermosel apparatus," Designation D 4402, Vol 04.04, West Conshohocken, PA.

. (2000s). "Test method for distillation of road tars," Designation D 20, Vol 04.03, West Conshohocken, PA.

Anderton, G. L., and Shoenberger, J. E. (1997). "Pavement technology application program project no. 4: Micro-surfacing, rejuvenators, and seal coats," Miscellaneous Paper GL-97-19, USAE Waterways Experiment Station, Vicksburg, MS, prepared for the U.S. Air Force Civil Engineering Support Agency, Tyndall AFB, Florida.

Boyer, R. E. (2000). "Asphalt rejuvenators "Fact or Fable." Transportation systems 2000 workshop proceedings. San Antonio, TX, 86-91.

Brown, E. R., and Johnson, R. R. (1976). "Evaluation of rejuvenators for bituminous pavements," Air Force Civil Engineering Center, AFCEC-TR-76-3, Tyndall AFB; USAE Waterways Experiment Station, Vicksburg, MS.

Coons, R. F., and Wright, P. H. (1968). "An investigation of the hardening of asphalt recovered from pavements of various ages." Proceedings, association of asphalt paving technologists. Vol 37, St. Paul, MN.

Gibson, Gary. (2000). Personnel communication, Pavements manager at MacDill AFB, Tampa, FL. 
Hall, J. W., Grau, R. W., Grogan, W. P., and Hachiya Y. (1992). "Performance indications from Army Airfield Pavement Management Program," ASTM STP 1121, "Pavement Management Implementation," American Society for Testing and Materials, Conshohocken, PA, 297-317.

Hass, R., Hudson, W. R., and Zaniewski, J. (1994). Modern pavement management. Krieger Publishing Co., Malabar, FL.

Mamlouk, M. S., and Zaniewski, J. P. (1998). "Pavement preventive maintenance: Description, effectiveness, and treatments," ASTM STP 1348, American Society for Testing and Materials, West Conshohocken, PA.

Peterson, D. E. (1985). "Life cycle cost analysis of pavements," NCHRP Synthesis 122, Transportation Research Board, Washington, DC.

Pickett, J.E. (1983). "Evaluation of rejuvenation of Lajes Field, Azores," Unpublished Letter Report, U.S. Army Engineer Waterways Experiment Station, Vicksburg, MS.

Sebaaly, P. E., Gopal, V., Dietz, J., and Epps, J. A. (1999). "Development of tests for coal tar emulsion sealers," Pavement Coating Technology Center, Research Report No. PCTC-2, Department of Civil Engineering, University of Nevada, Reno, NV.

Shipman, Gerald, W. (2001). Personnel communication, Engineer, Missouri DOT.

Shoenberger, J. E. (2001). "Material properties and characteristics for development of an expert system for coal-tar sealers," Technical Report ERDC/GSL TR-01-15, U.S. Army Engineer and Research and Development Center, Vicksburg, MS.

Sholar, G. A., Musselman, J. A., and Page, G. C. (2000). "An evaluation of a sealer-rejuvenator treatment," Research Report FL/DOT/SMO/00-440, Florida State Materials Office.

Webster. (1977). "Webster's New Collegiate Dictionary," Merriam-Webster, G. \& C. Merriam Co., Springfield, MA. 


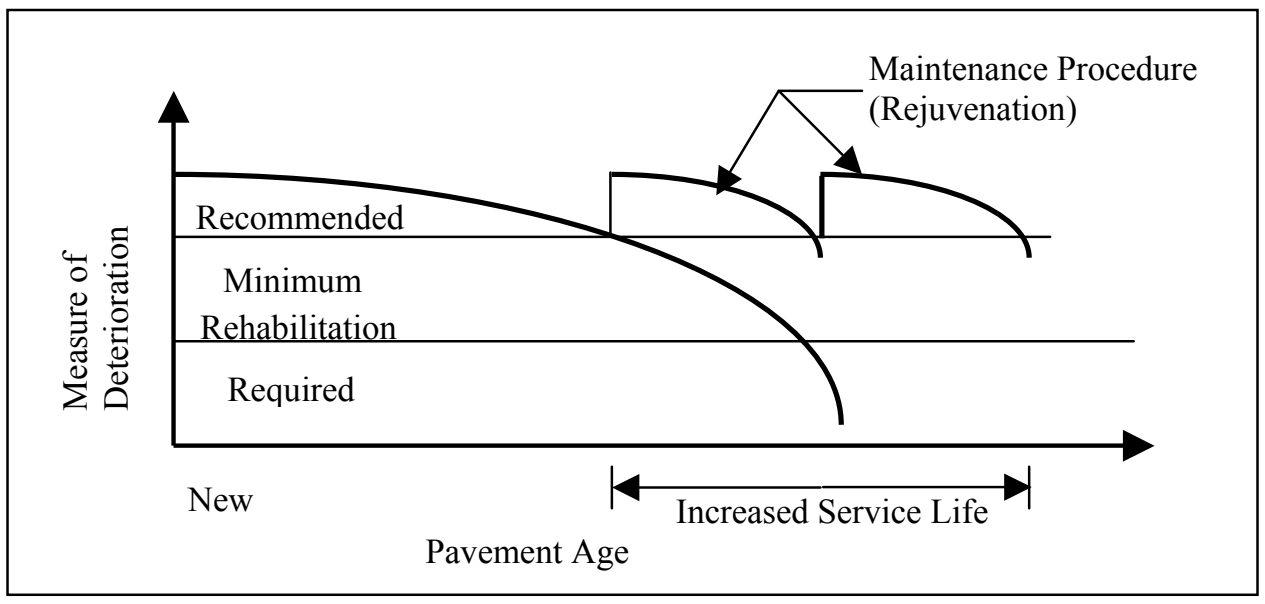

Figure 1. Effect of preventive maintenance on service life

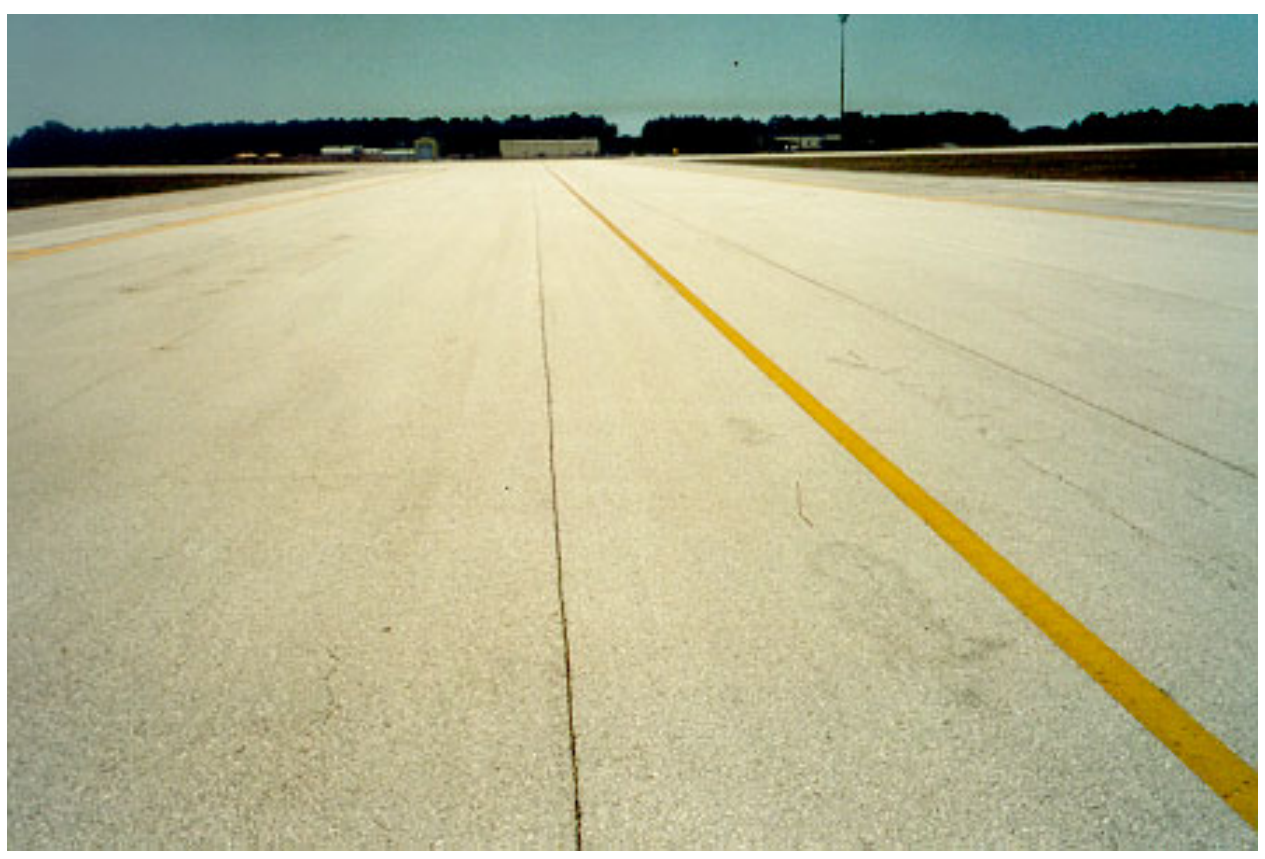

Figure 2. Overall view of Taxiway $\mathrm{O}$ 


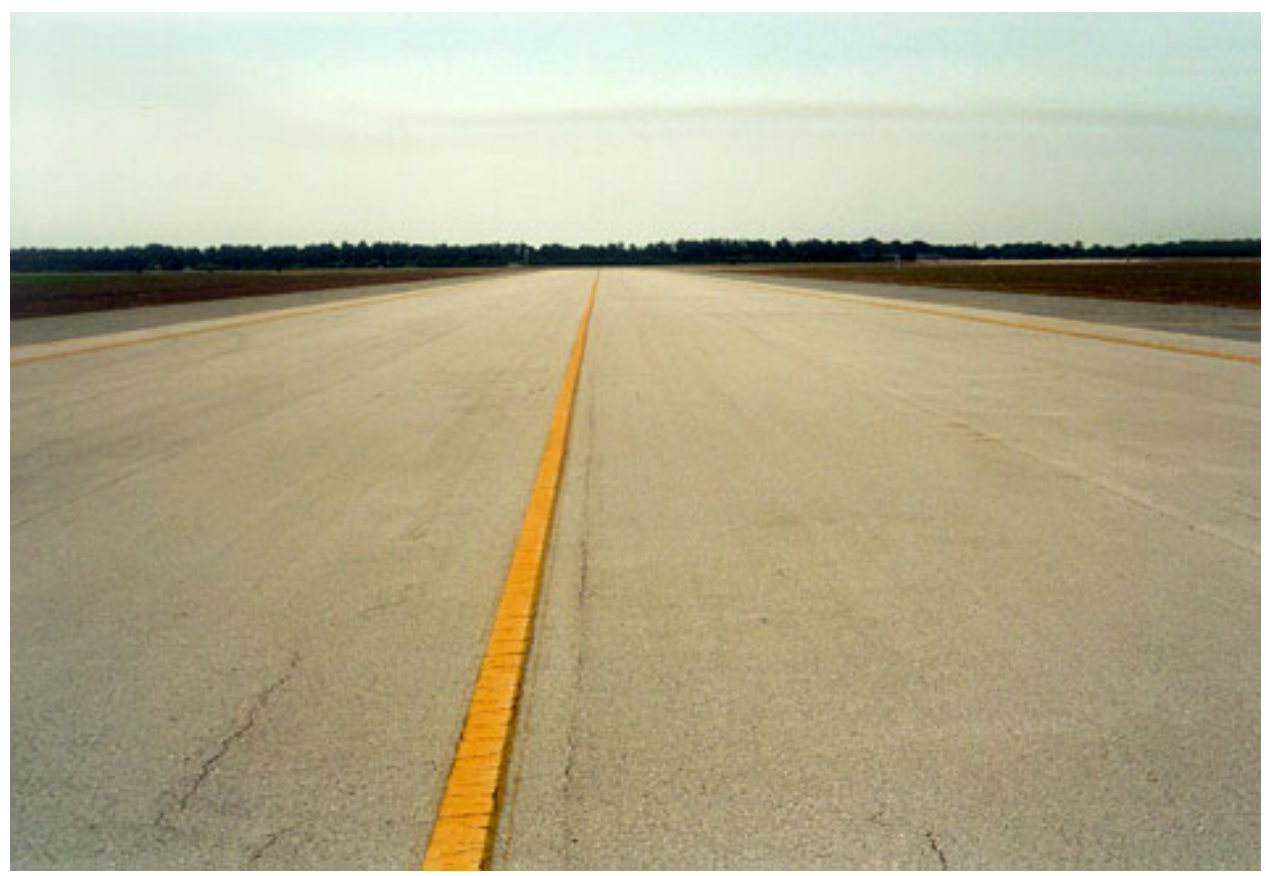

Figure 3. Overall view of Taxiway M

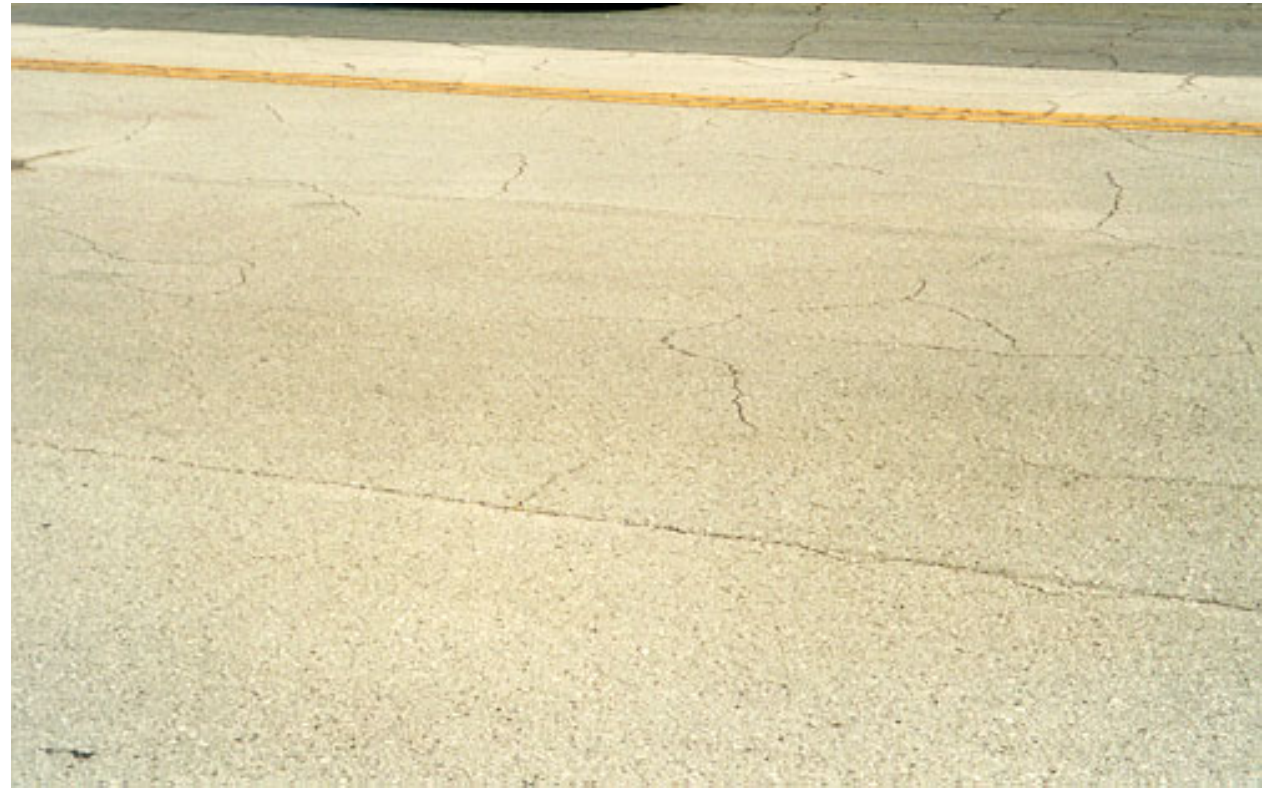

Figure 4. Typical block and longitudinal cracking on Taxiways $\mathrm{O}$ and $\mathrm{M}$ at MacDill AFB 


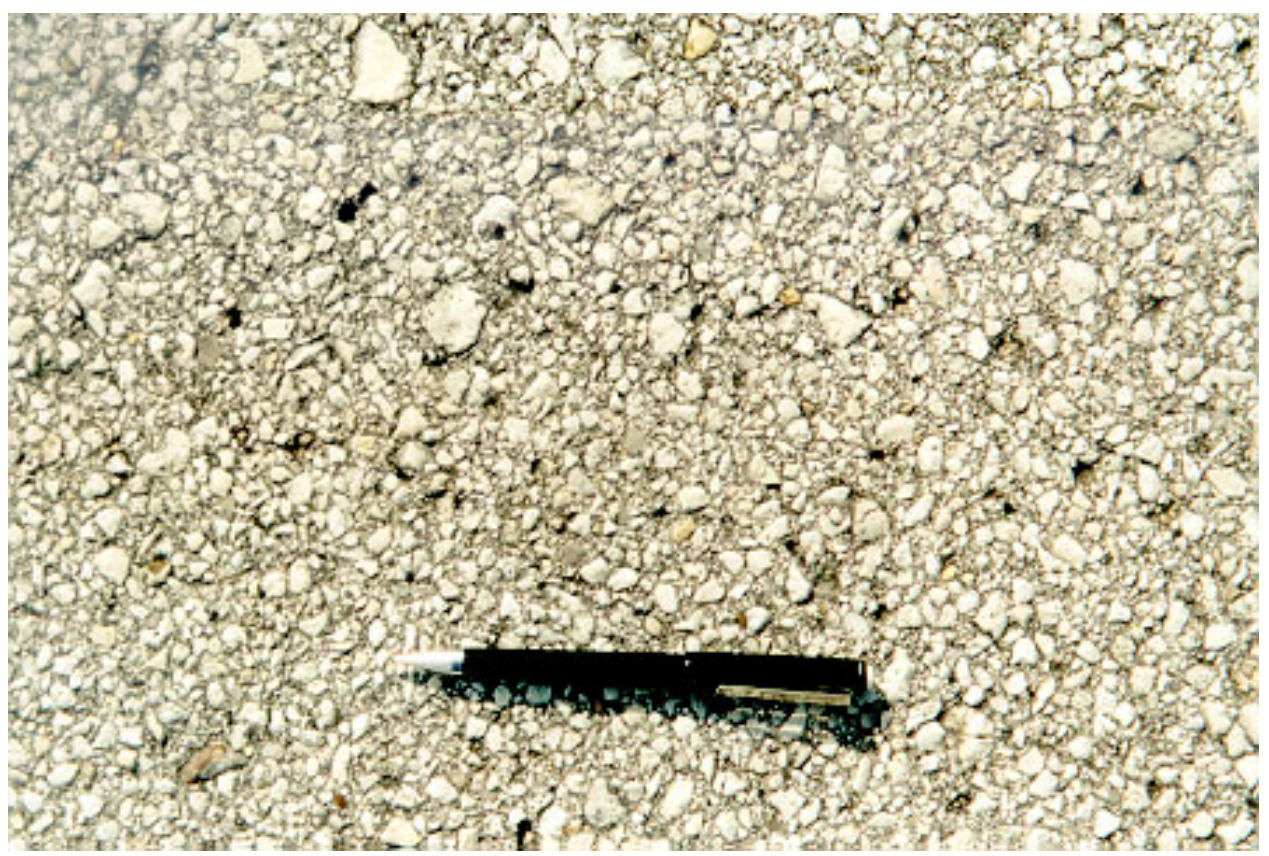

Figure 5. Closeup view of HMA surface on Taxiway M (similar to that of Taxiway O) at MacDill AFB

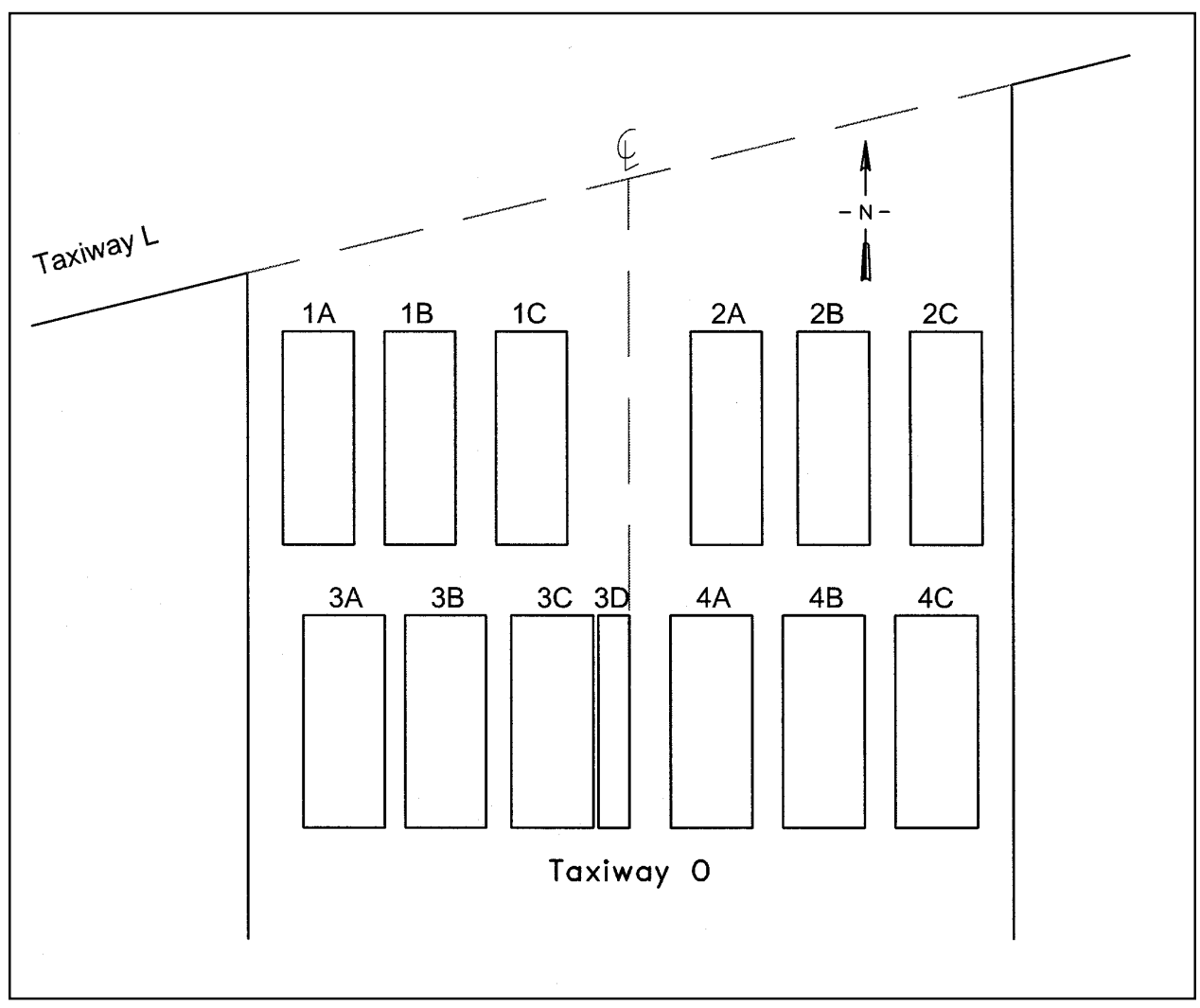

Figure 6. Layout of test items on Taxiway O, MacDill AFB 


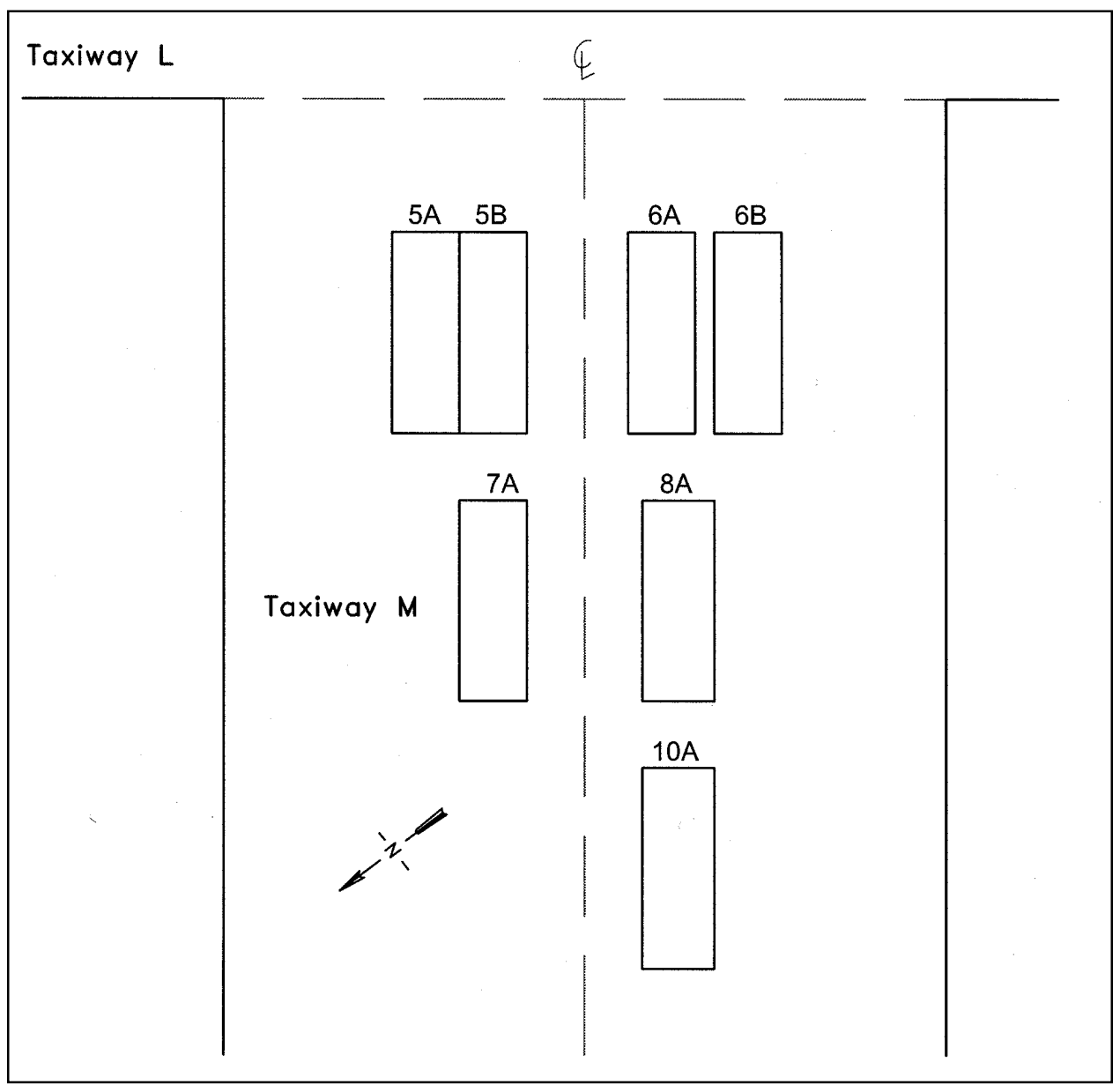

Figure 7. Layout of test items on Taxiway M, MacDill AFB (Area No. 9, opposite of $10 \mathrm{~A}$, had no materials applied) 


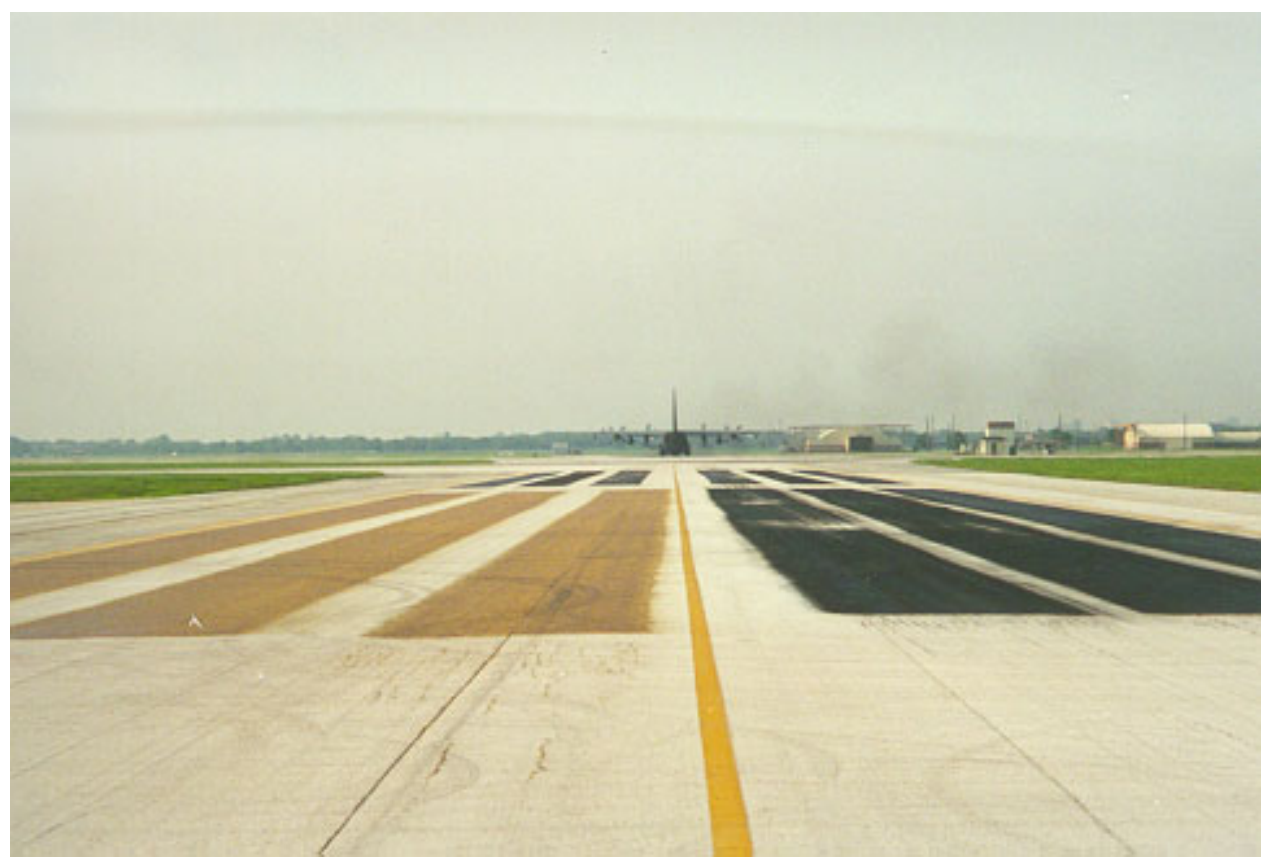

Figure 8. View of Taxiway $\mathrm{O}$ after application of test materials but prior to application of Antiskid material (Figure 6)

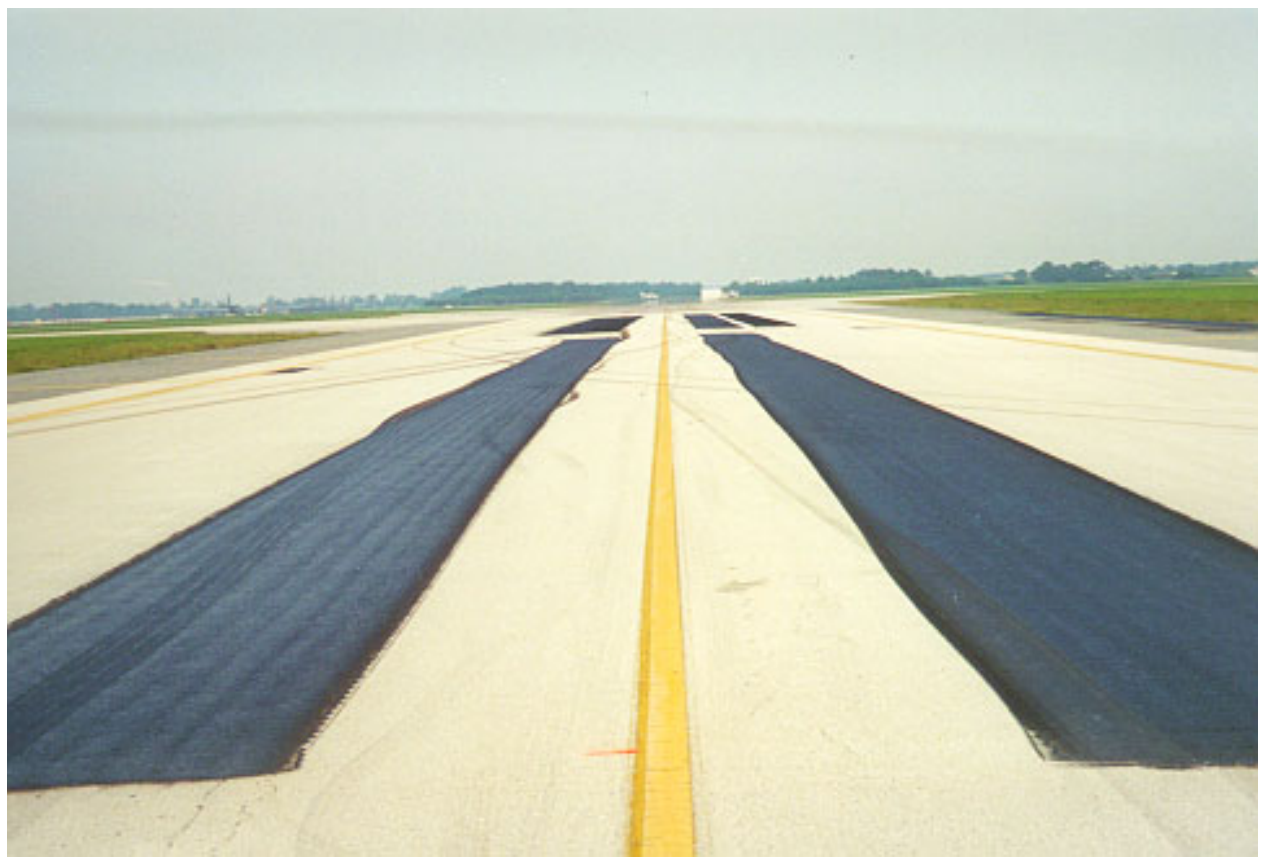

Figure 9. View of Taxiway $\mathrm{M}$ after application of test materials but prior to application of CPR material (Figure 7) 


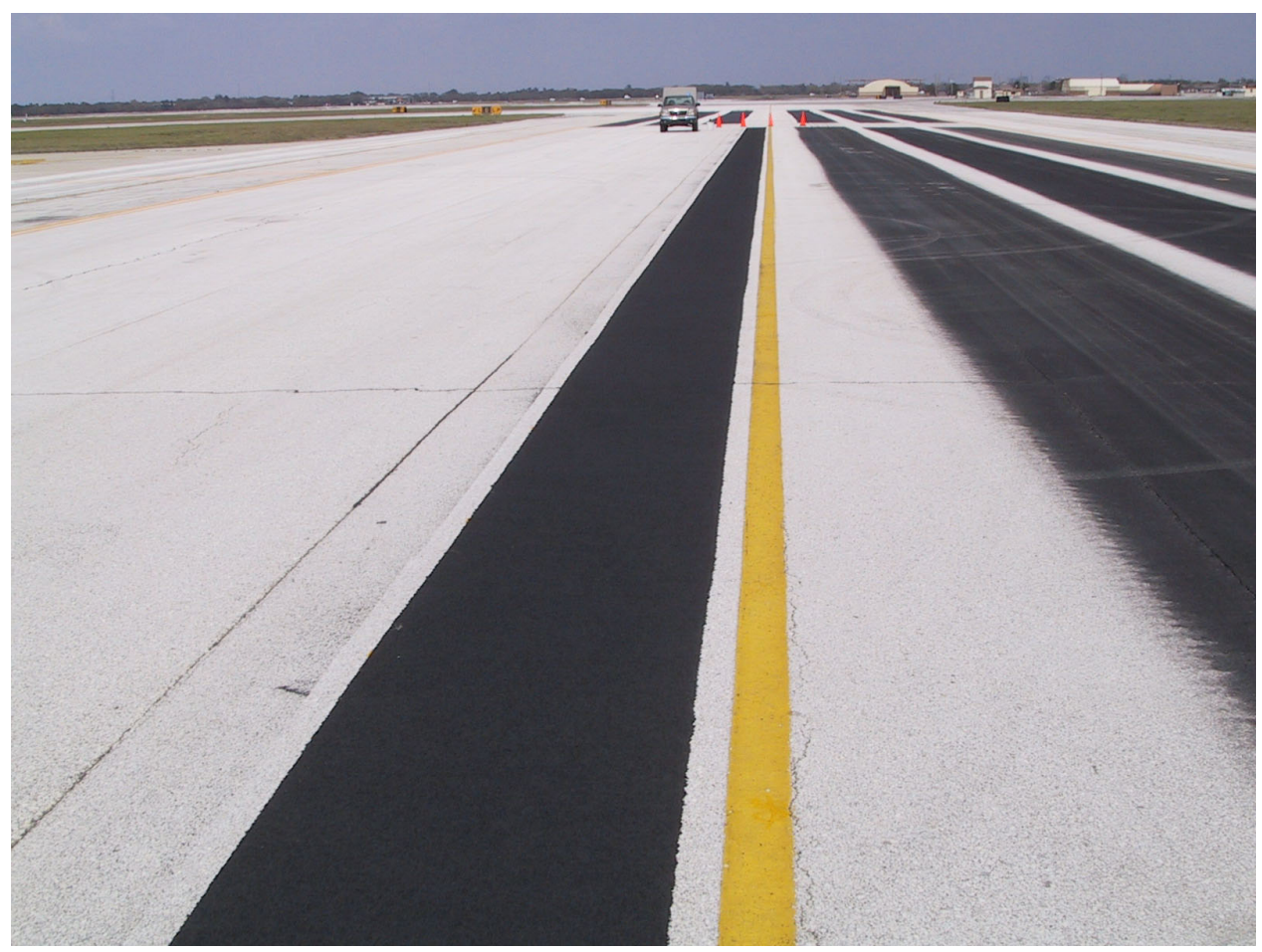

Figure 10. View of Antiskid material to left of the taxiway center line. Note: 7 months after placement, Reclamite (placed to left of the Antiskid) is barely visible

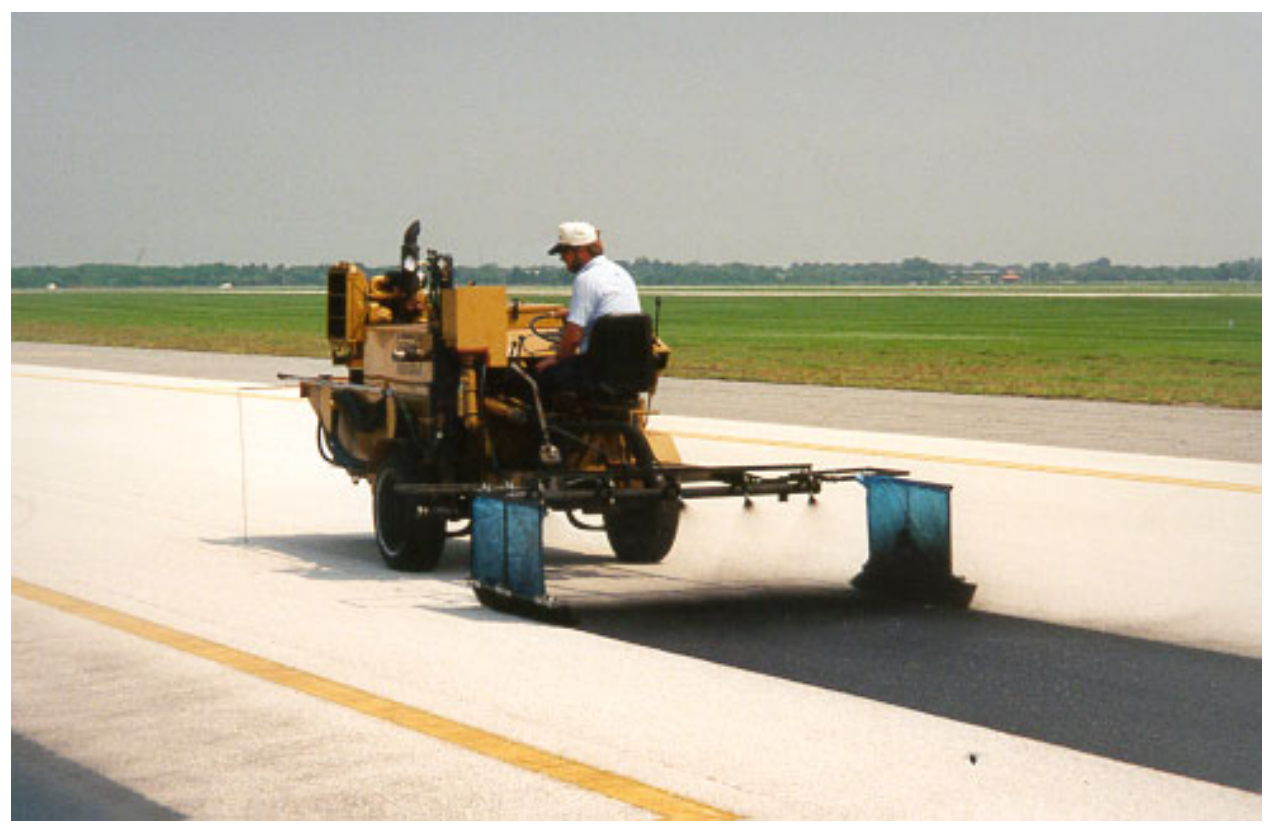

Figure 11. Spray application equipment applying Polytar sealer 


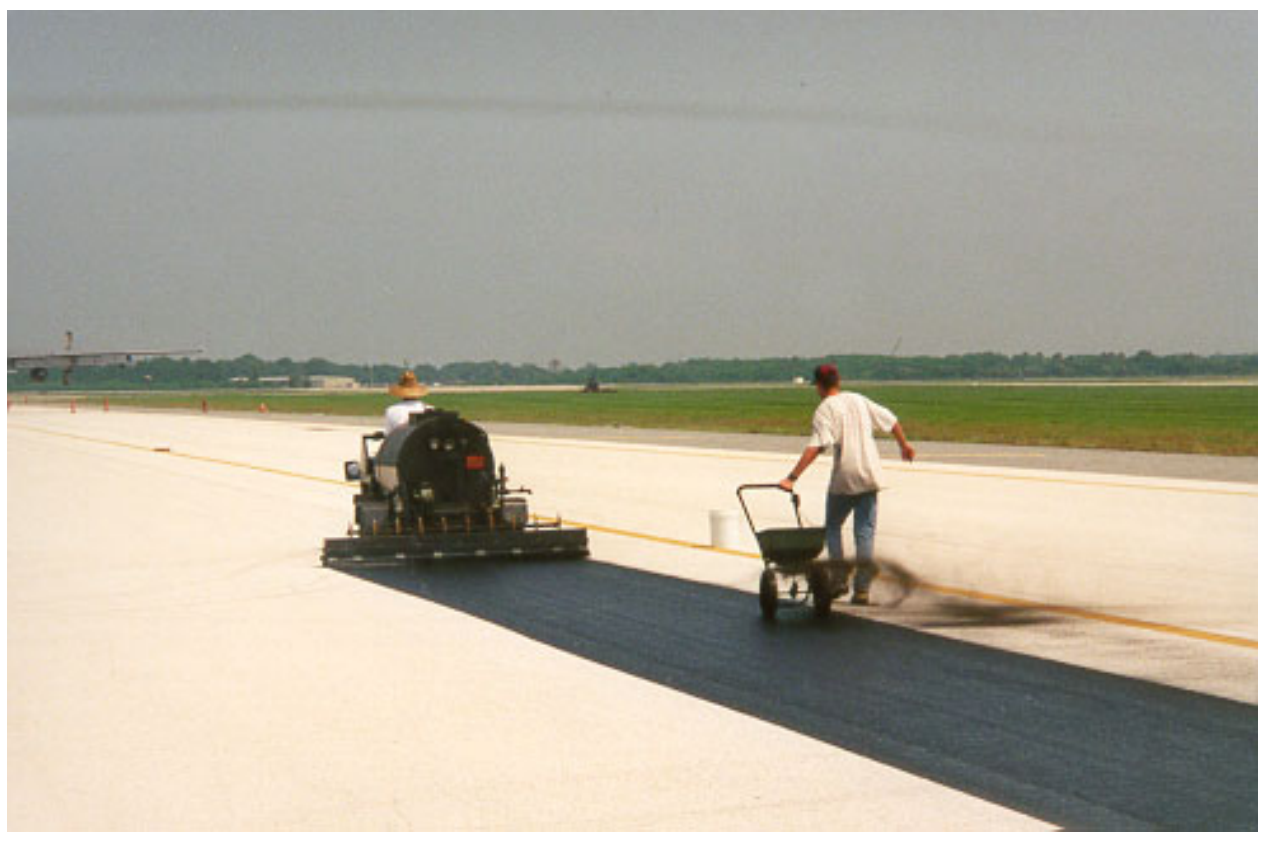

Figure 12. Spray application equipment applying CBRT-SO. Note application of sand to treated surface

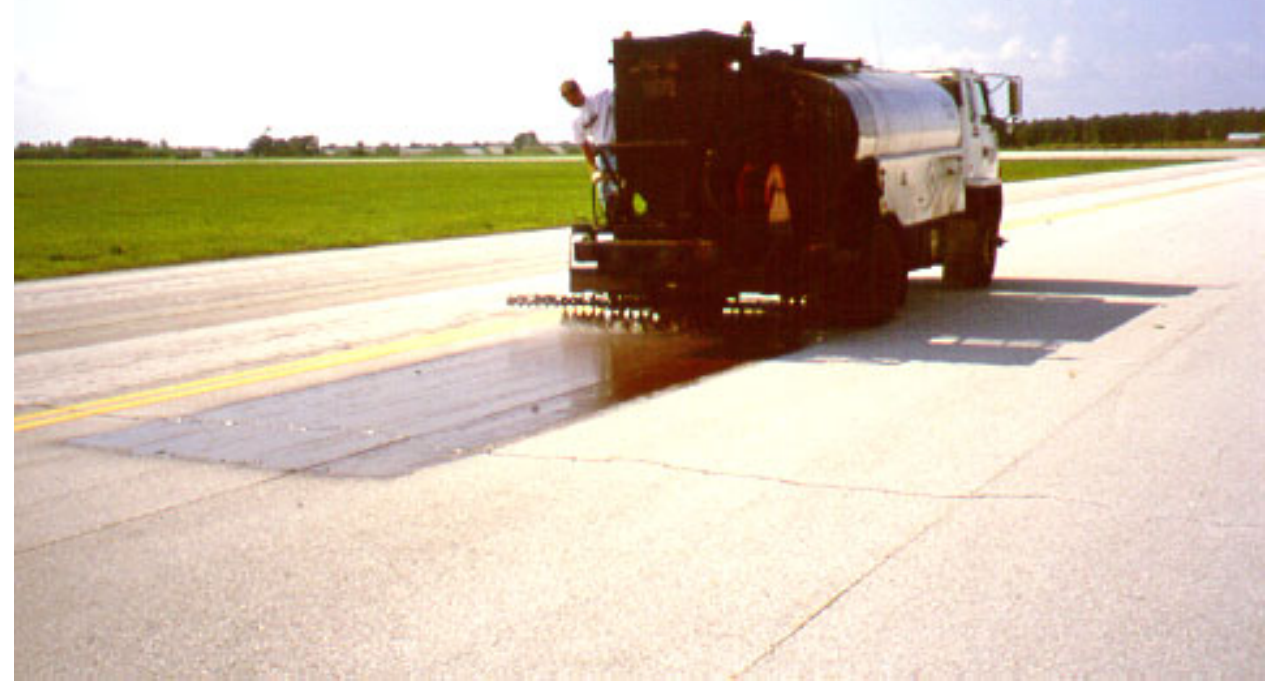

Figure 13. Spray application of GSB-modified, sand immediately applied on top of emulsion 


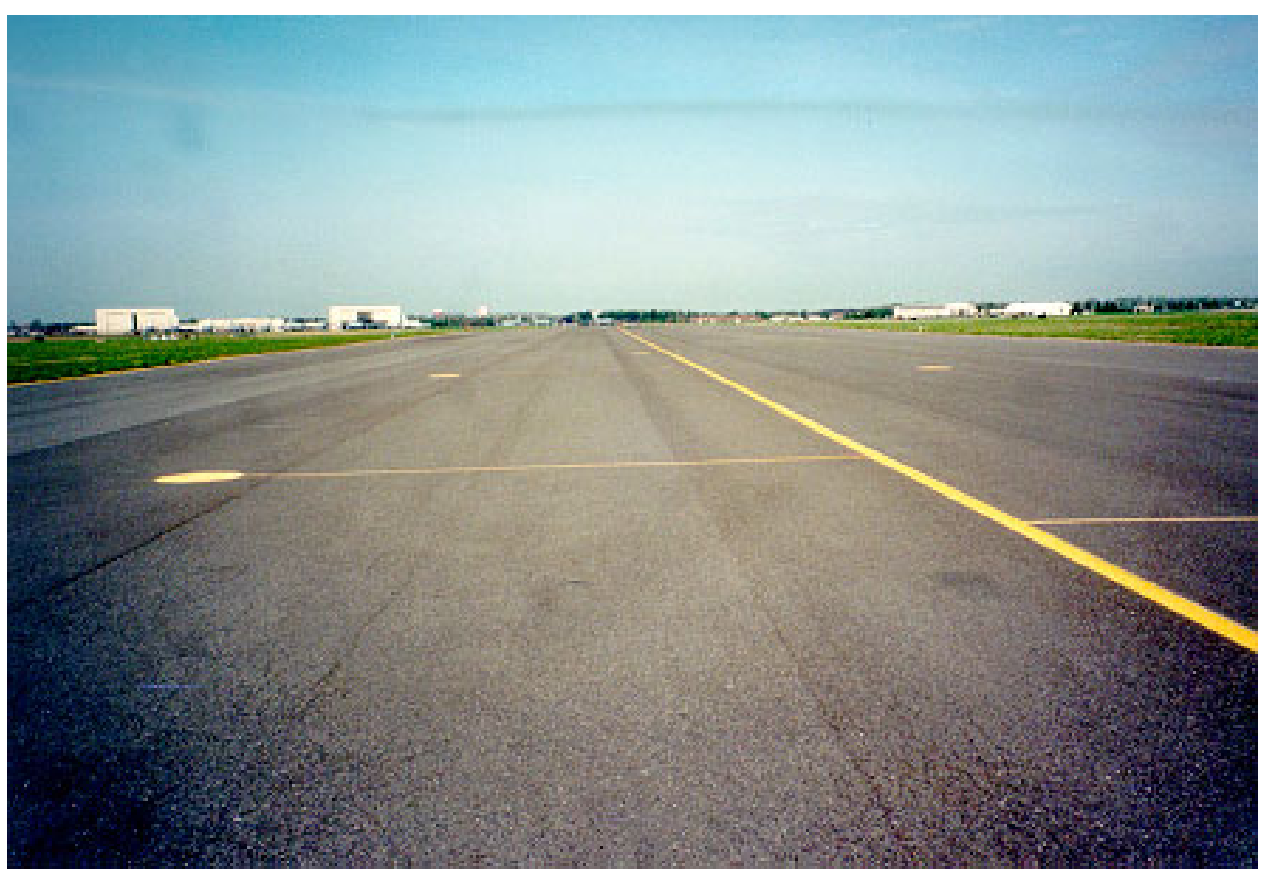

Figure 14. Overall view of Taxiway $L$ at McGuire AFB

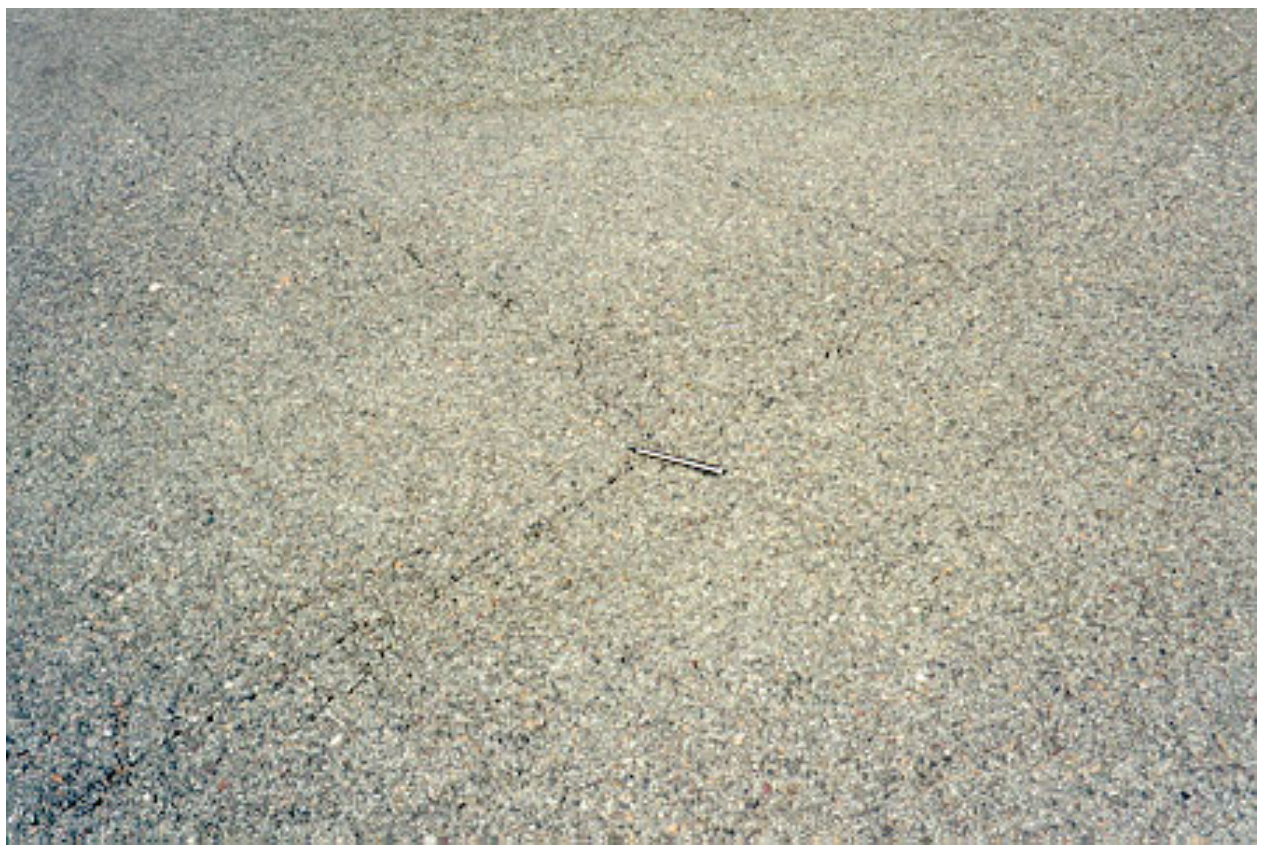

Figure 15. Typical block cracking on Taxiway $L$ at McGuire AFB 


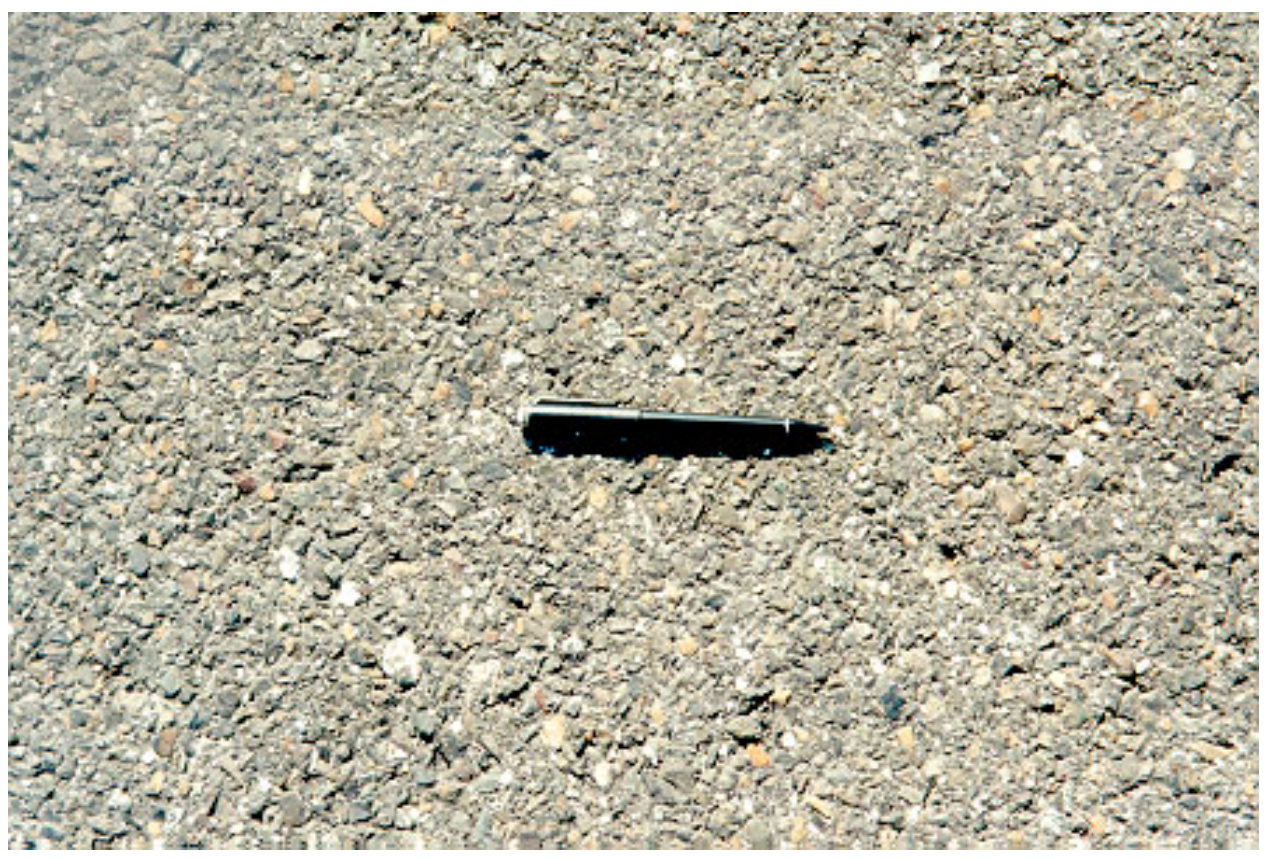

Figure 16. Closeup view of HMA surface on Taxiway $L$ at McGuire AFB

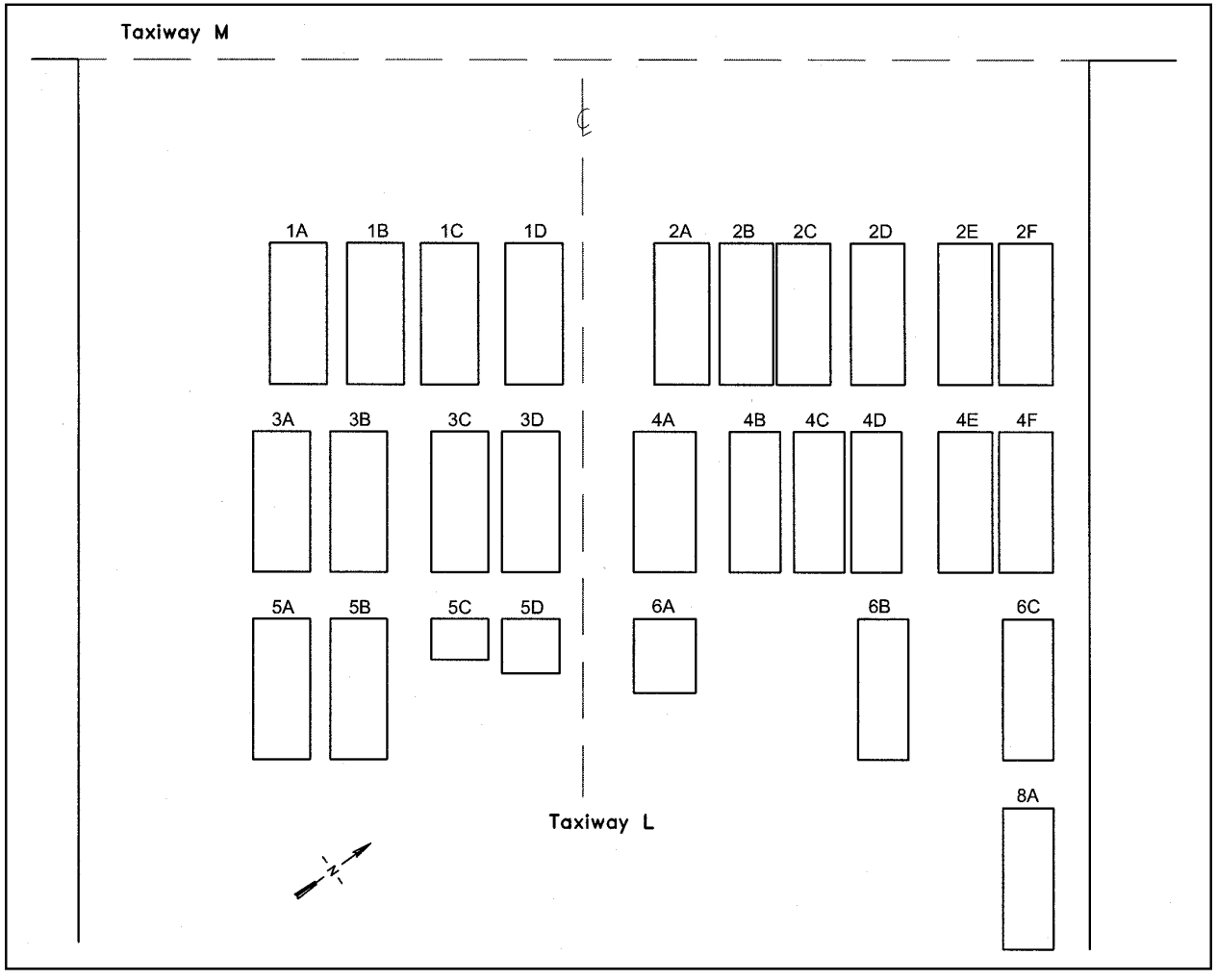

Figure 17. Layout of test items on Taxiway L, McGuire AFB 


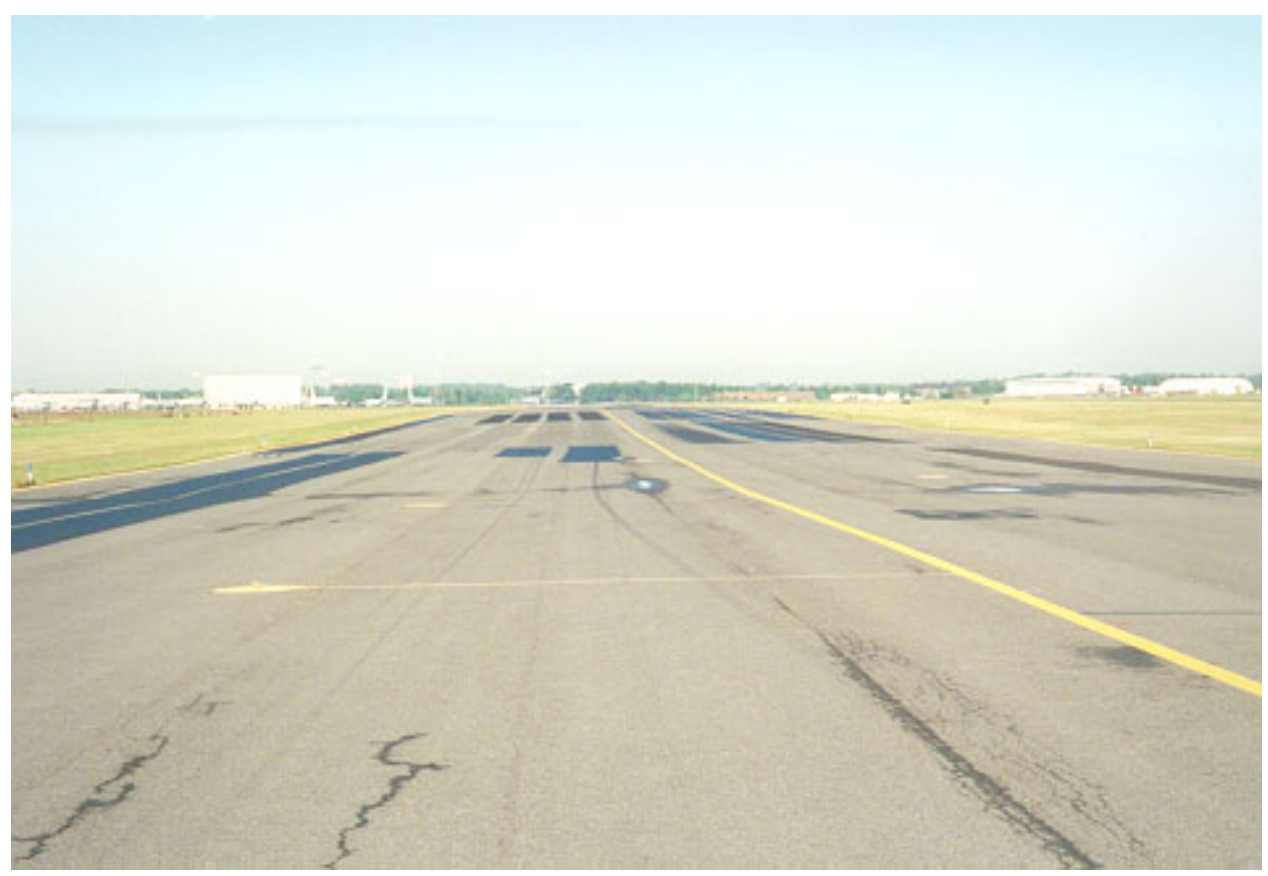

Figure 18. View of Taxiway $L$ after application of test materials but prior to application of LAS-320 and CPR materials (Figure 16)

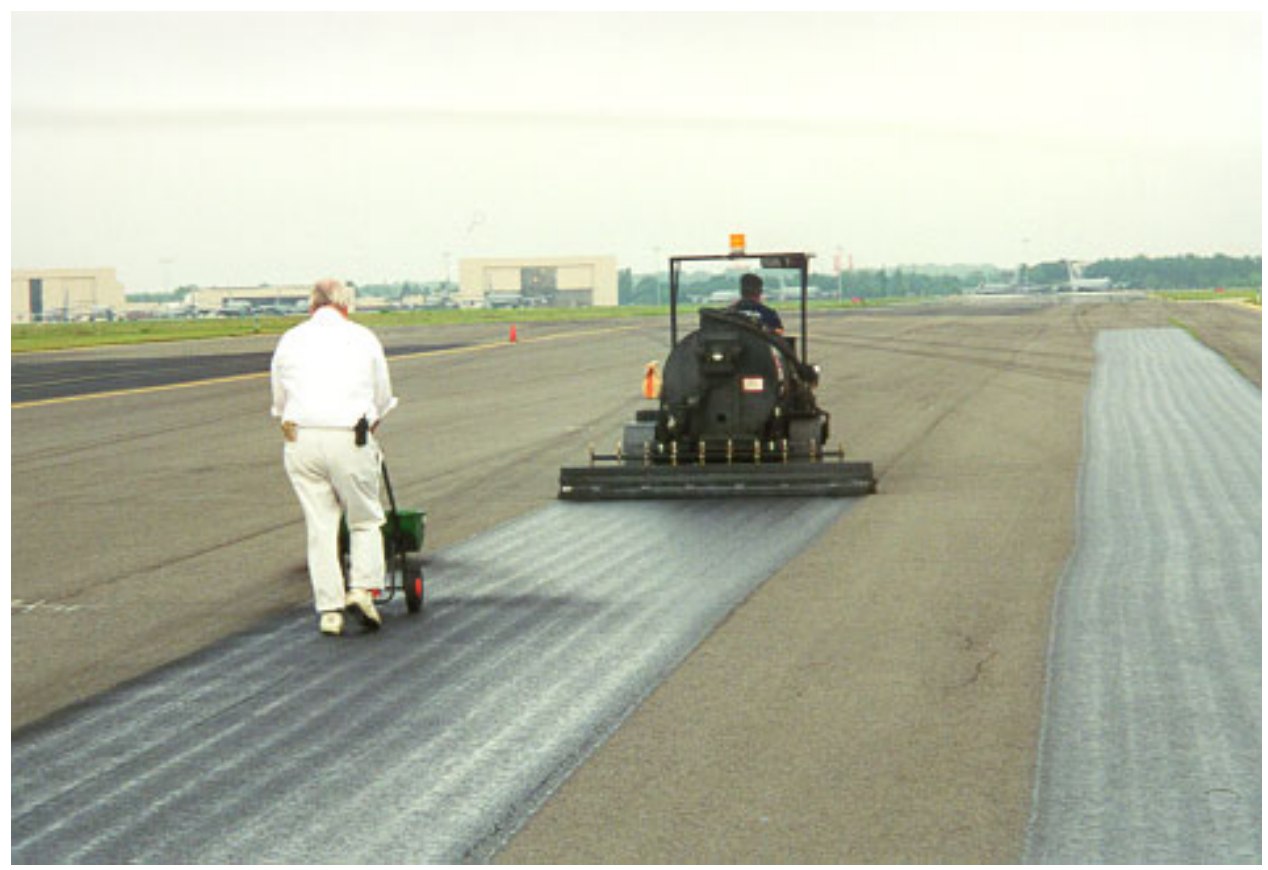

Figure 19. Applying BCR-2000 emulsion, with sand spread by hand-pushed applicator immediately on the treated surface (MacDill AFB) 


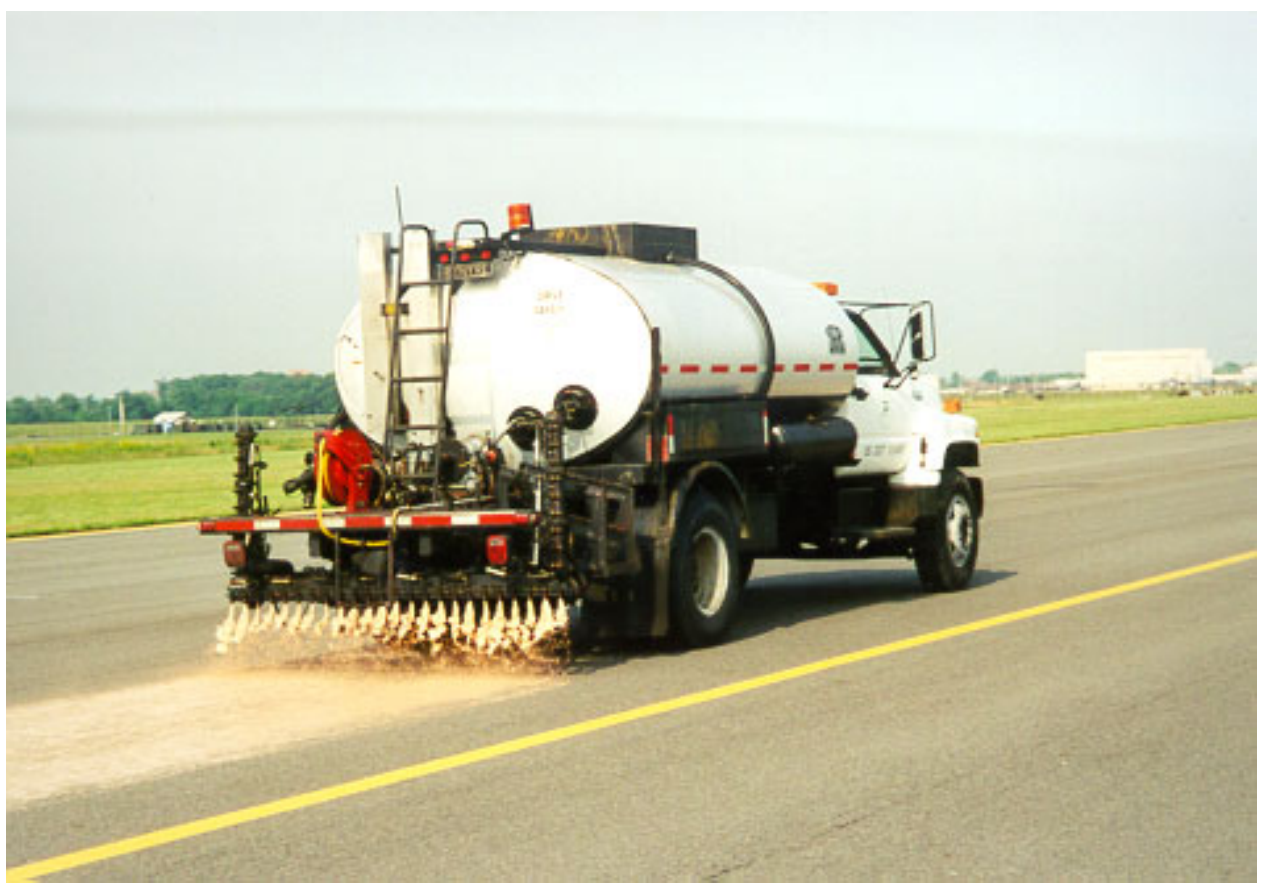

Figure 20. Spray application of Reclamite on the pavement surface (McGuire AFB)

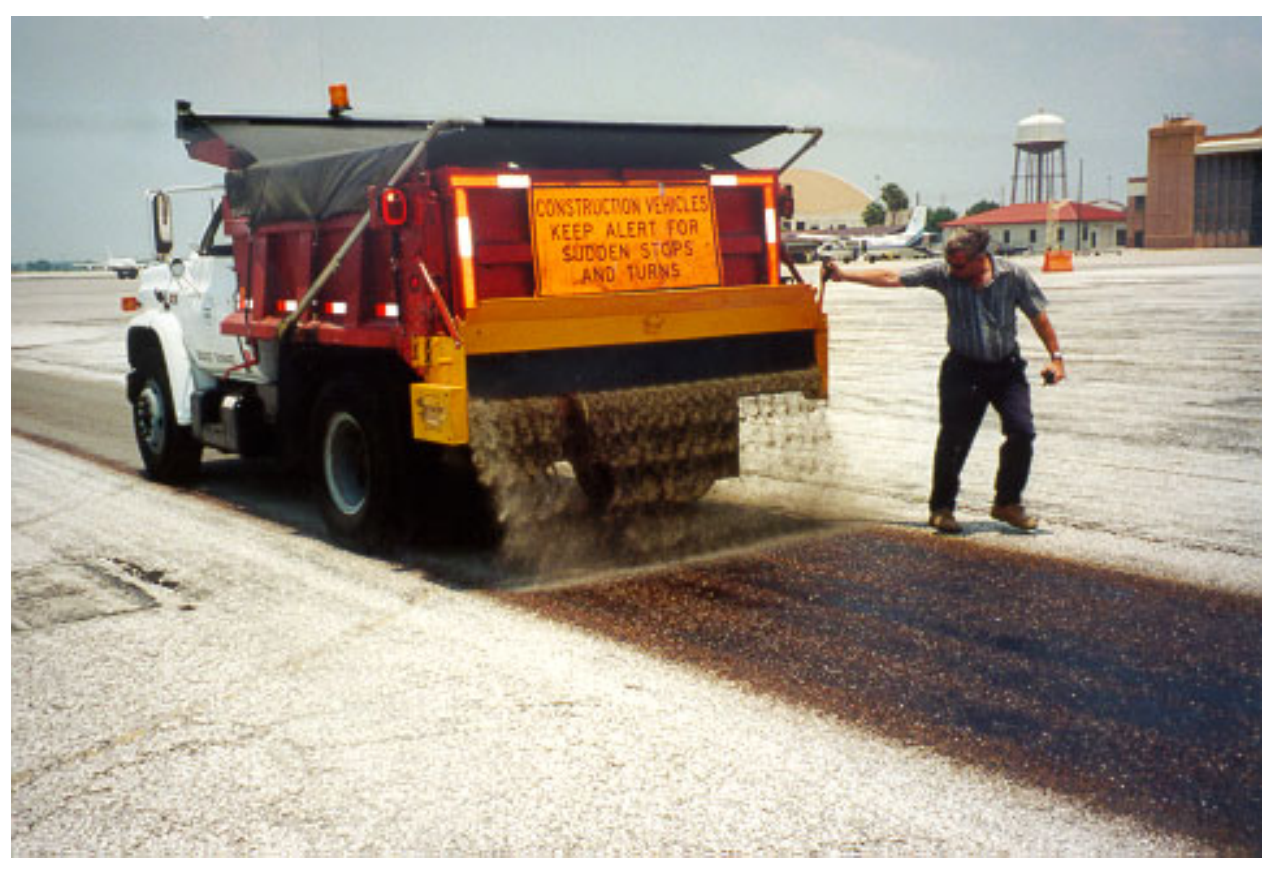

Figure 21. Spreading sand over CRF emulsion 


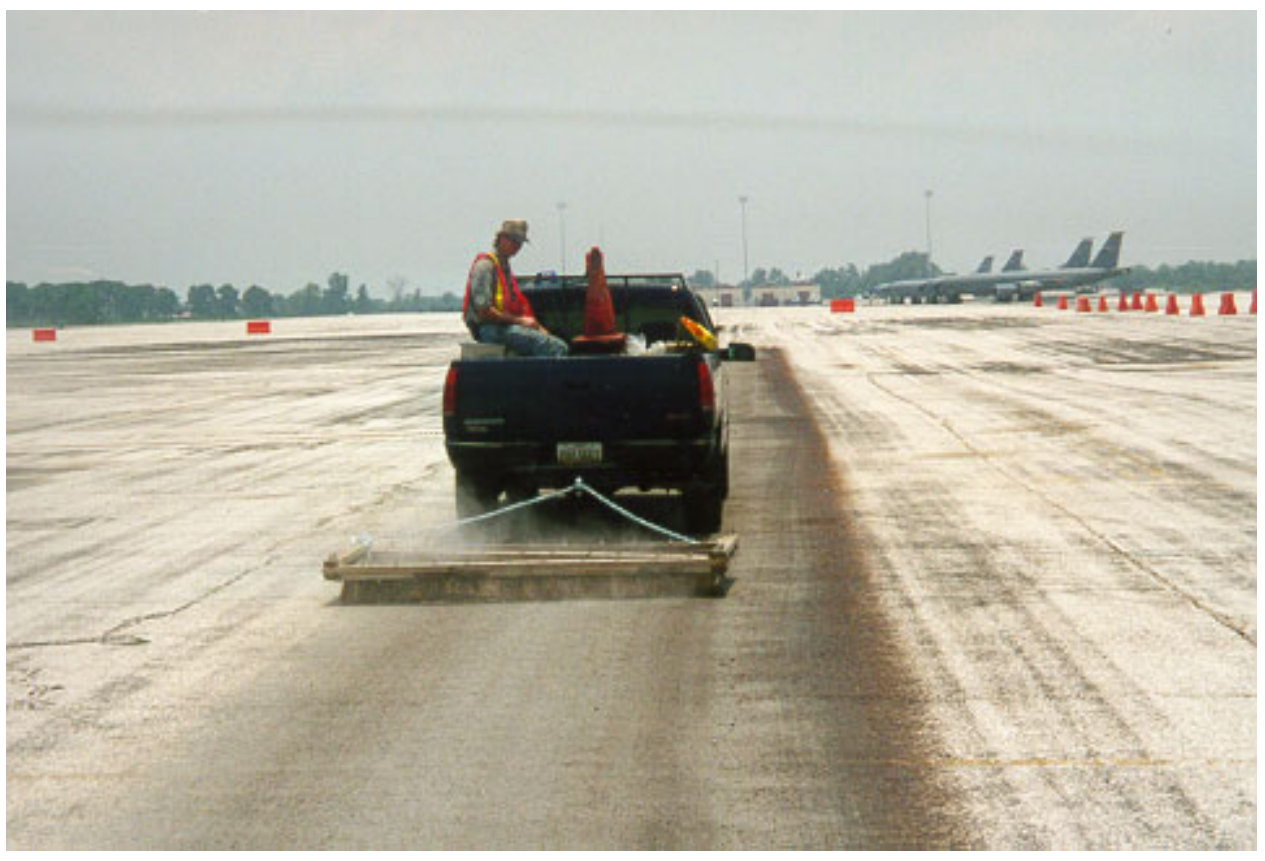

Figure 22. Working sand into the CRF emulsion with a drag broom

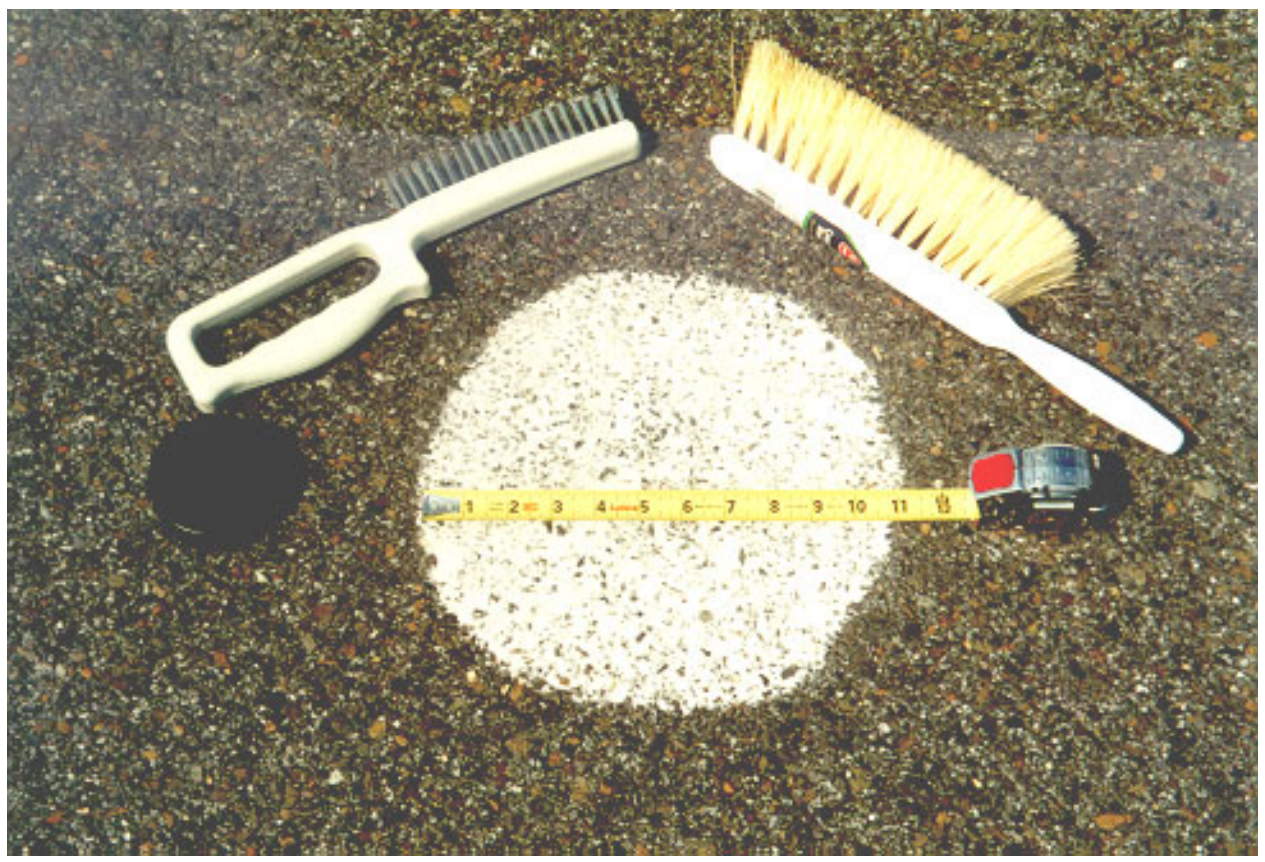

Figure 23. Sand patch equipment and measurement at McGuire AFB 


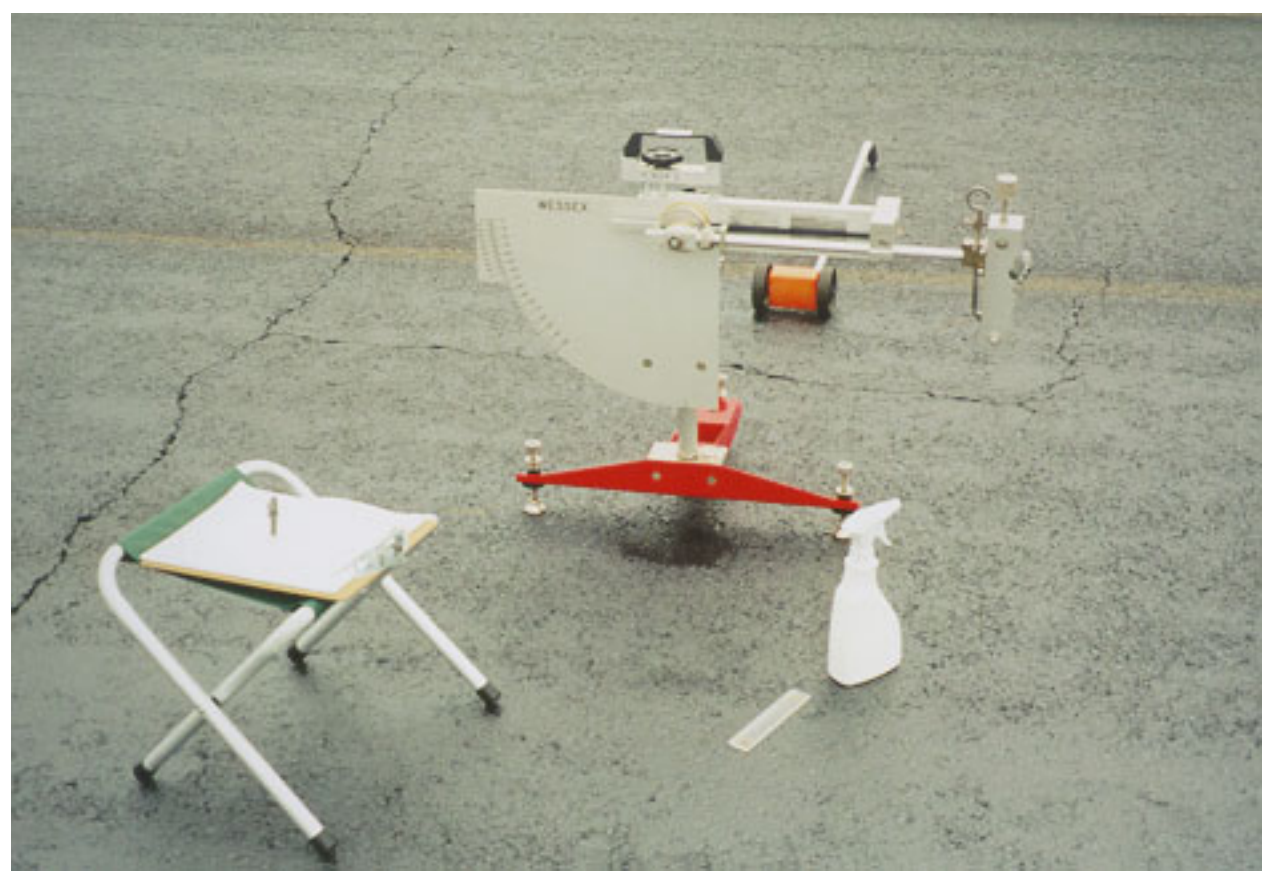

Figure 24. British Pendulum test equipment

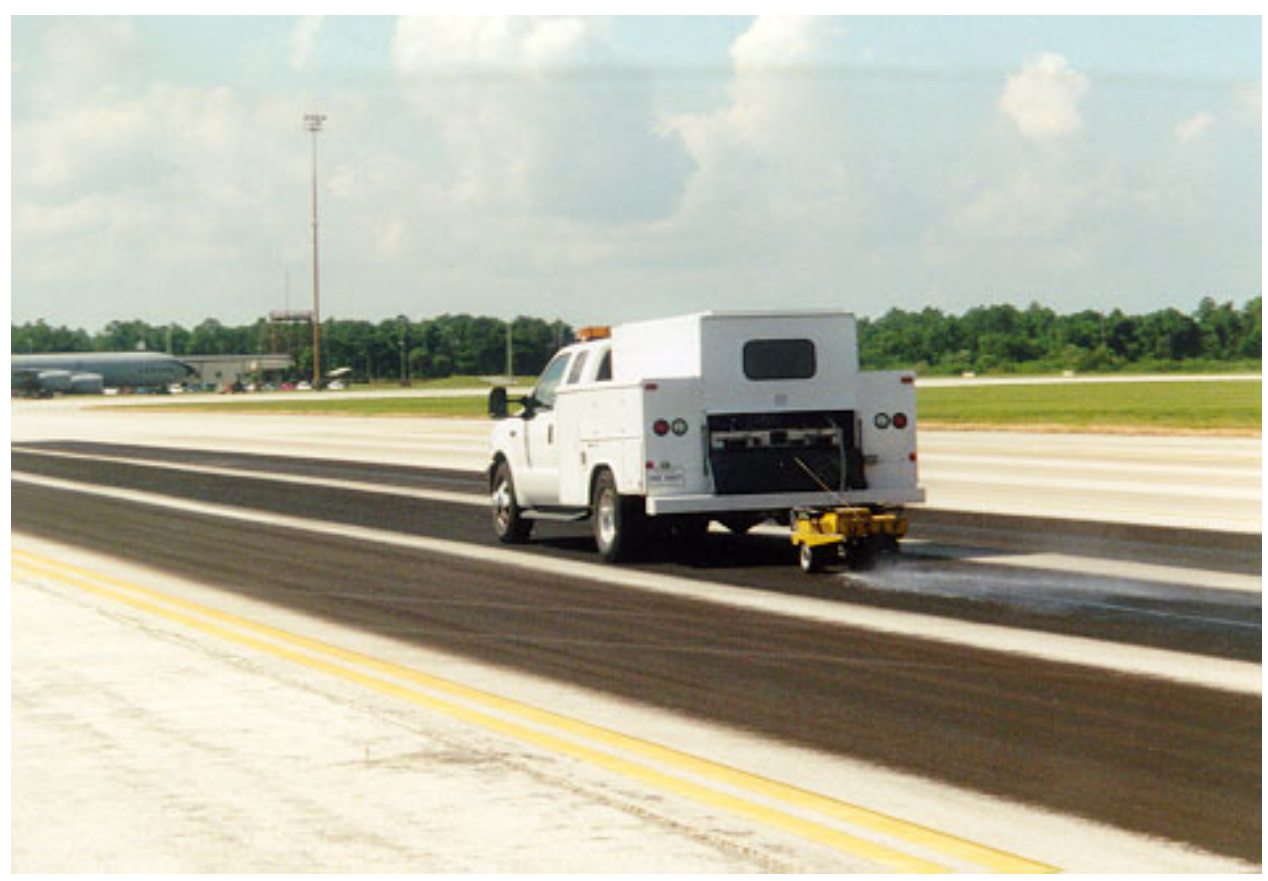

Figure 25. GripTester on Taxiway $O$ at MacDill AFB 


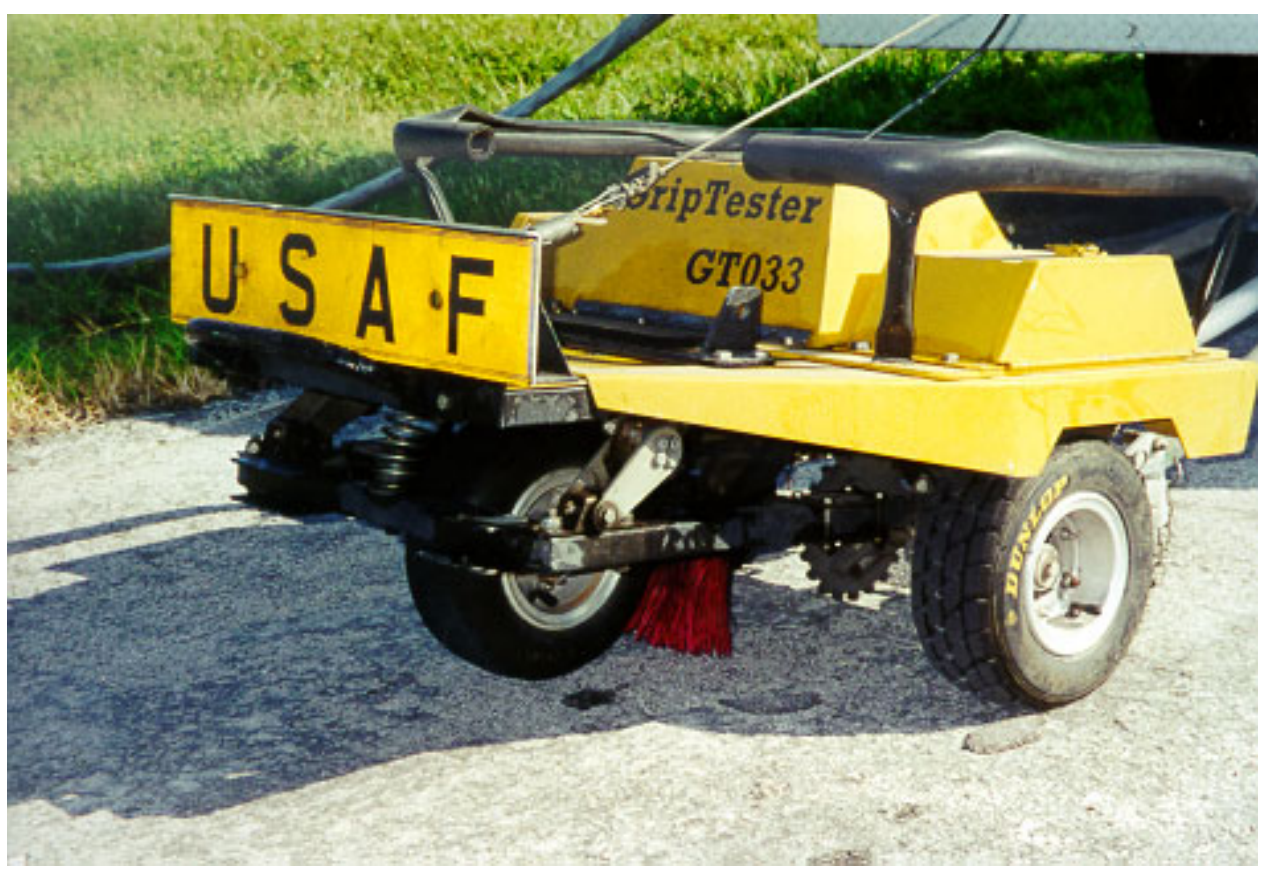

Figure 26. Test wheel on Grip Tester device

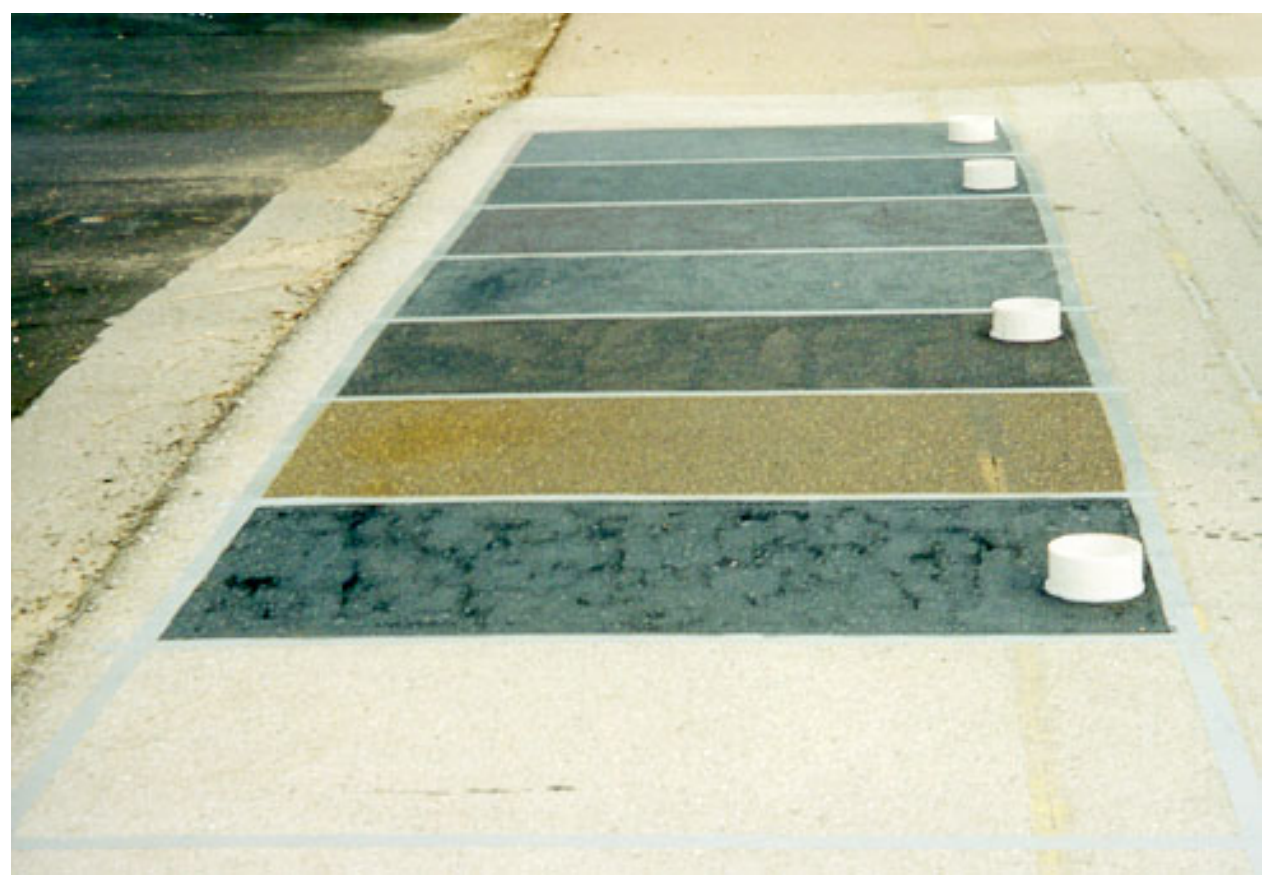

Figure 27. Overall view of ERDC test sections; fuel-resistant materials have PVC pipe on them for fuel-resistance test 


\begin{tabular}{|c|}
\hline Control 2 \\
\hline CBRT-SO \\
\hline BCR-2000 \\
\hline APR-100 \\
\hline GSB-mod \\
\hline LAS-320 \\
\hline Reclamite \\
\hline RejuvaSeal N \\
\hline
\end{tabular}

Figure 28. Layout of ERDC test sections (drawing not to scale); areas $0.9 \mathrm{~m} \times 1.8 \mathrm{~m}(1 \mathrm{yd} \times 2 \mathrm{yd})$ 


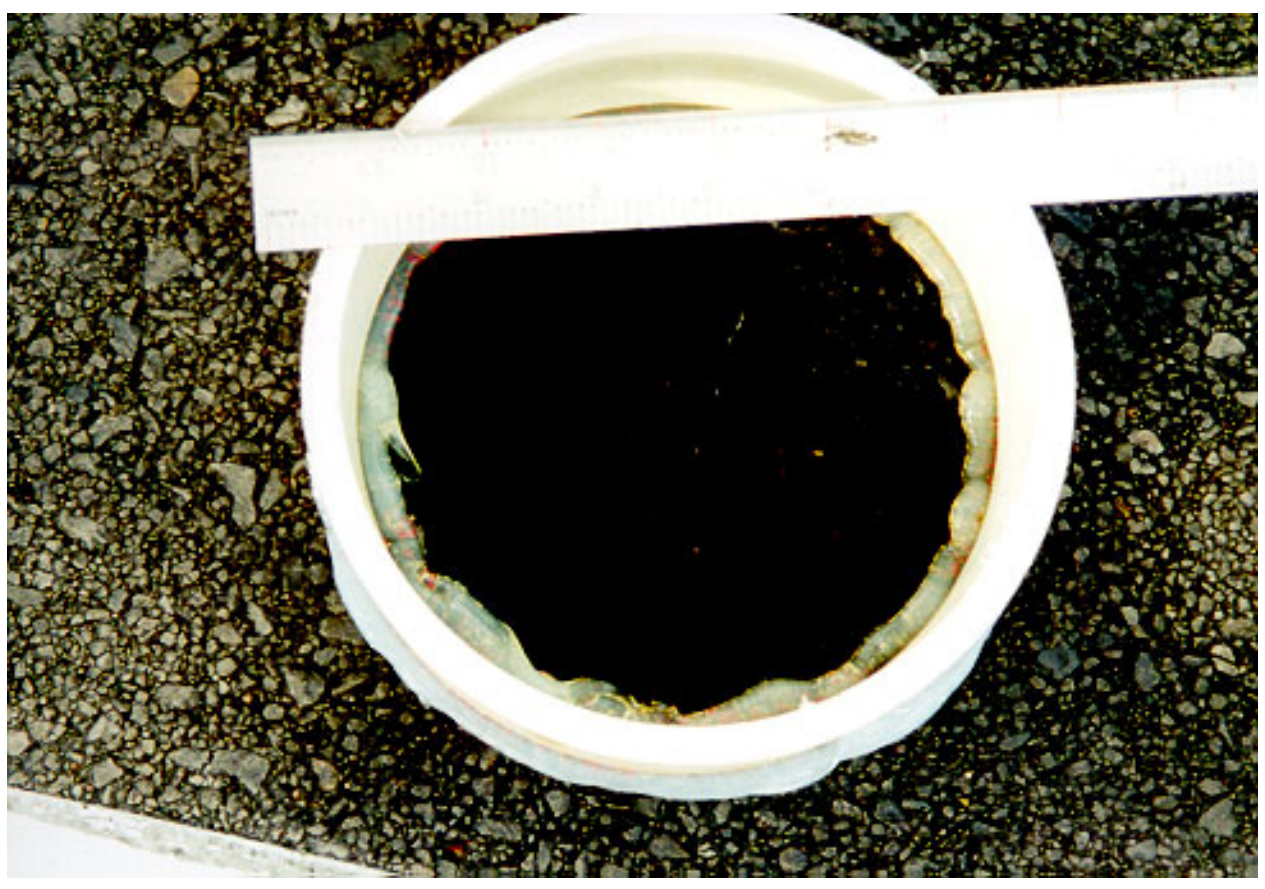

Figure 29. PVC (6-in.-diam) pipe attached to the pavement with silicon sealant. Note: Damaged pavement surface after fuel removal and loss of some surface aggregate

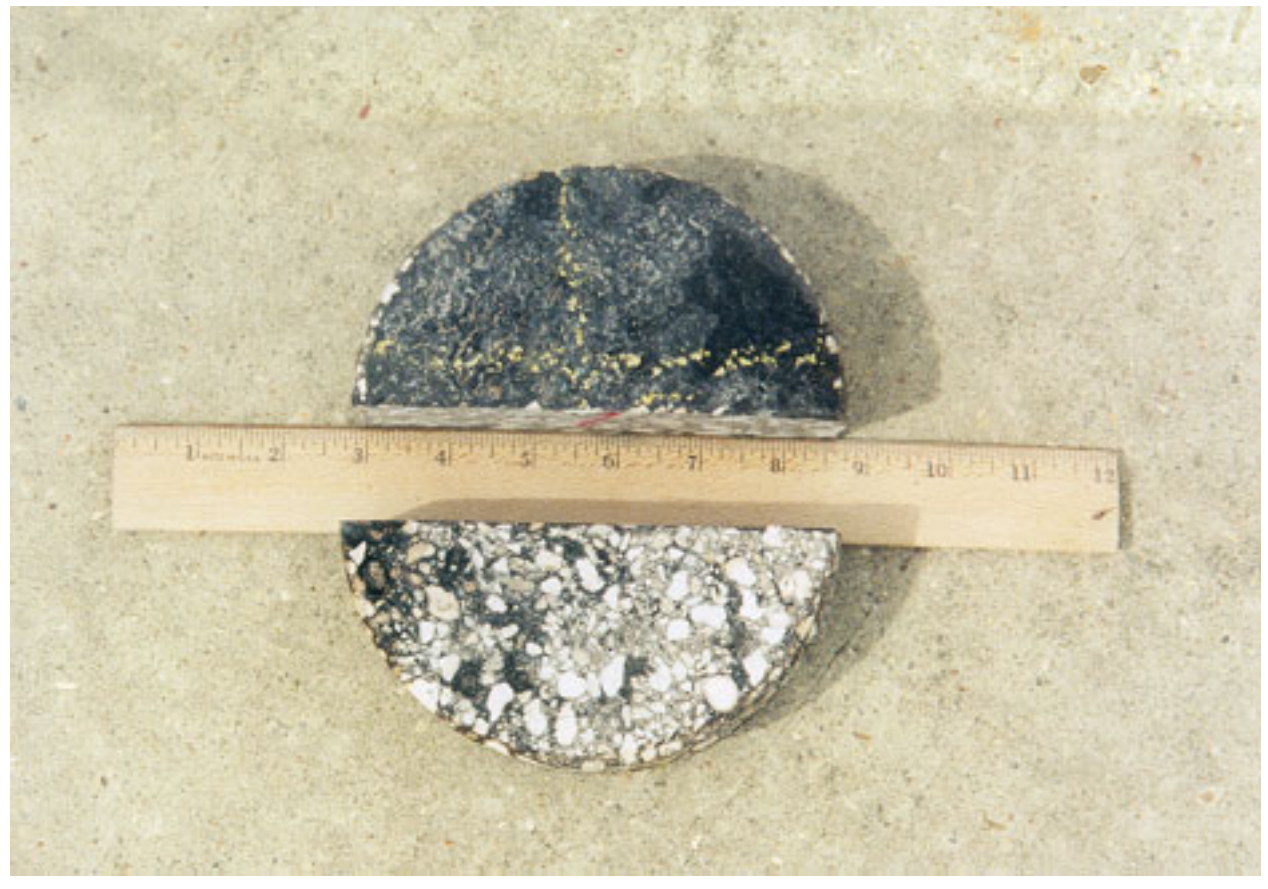

Figure 30. Asphalt pavement core with top $1 \mathrm{~mm}(0.04 \mathrm{in}$.) removed from bottom half 


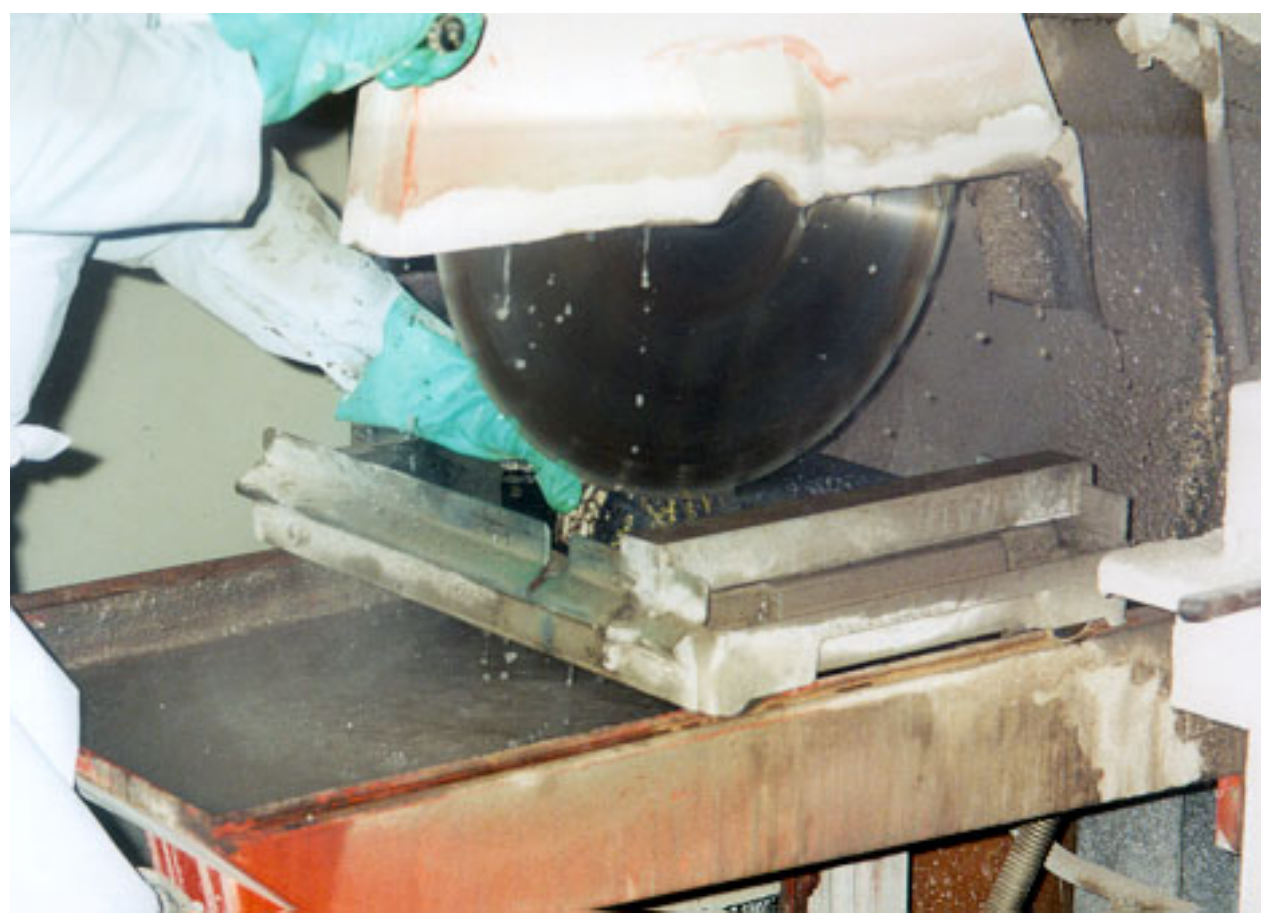

Figure 31. Concrete saw used to prepare asphalt cores for testing 


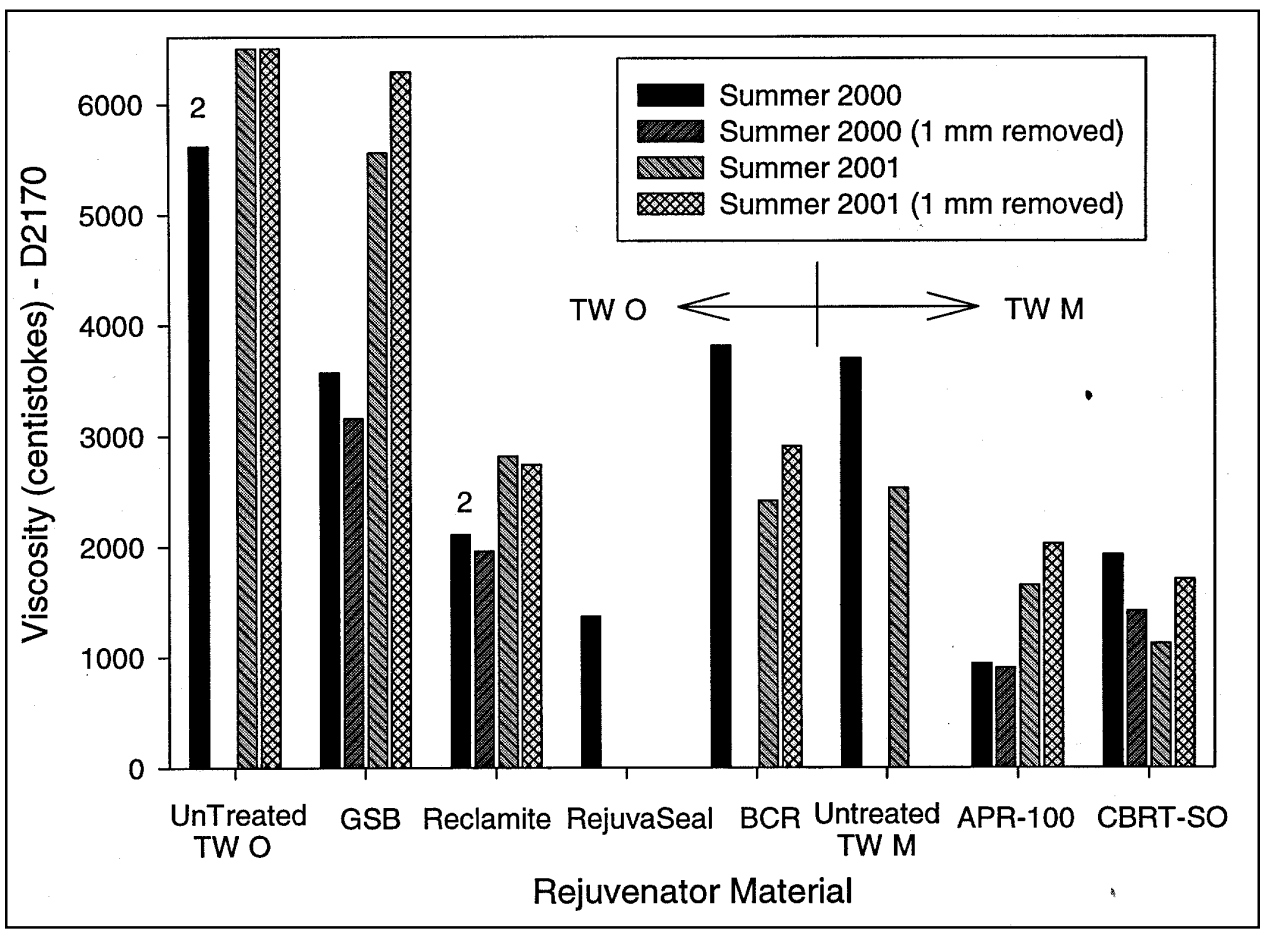

Figure 32. Viscosity test results of extracted asphalt binders from MacDill AFB (Note: Numbers above bars indicate the number of individual tests on which the result is based)

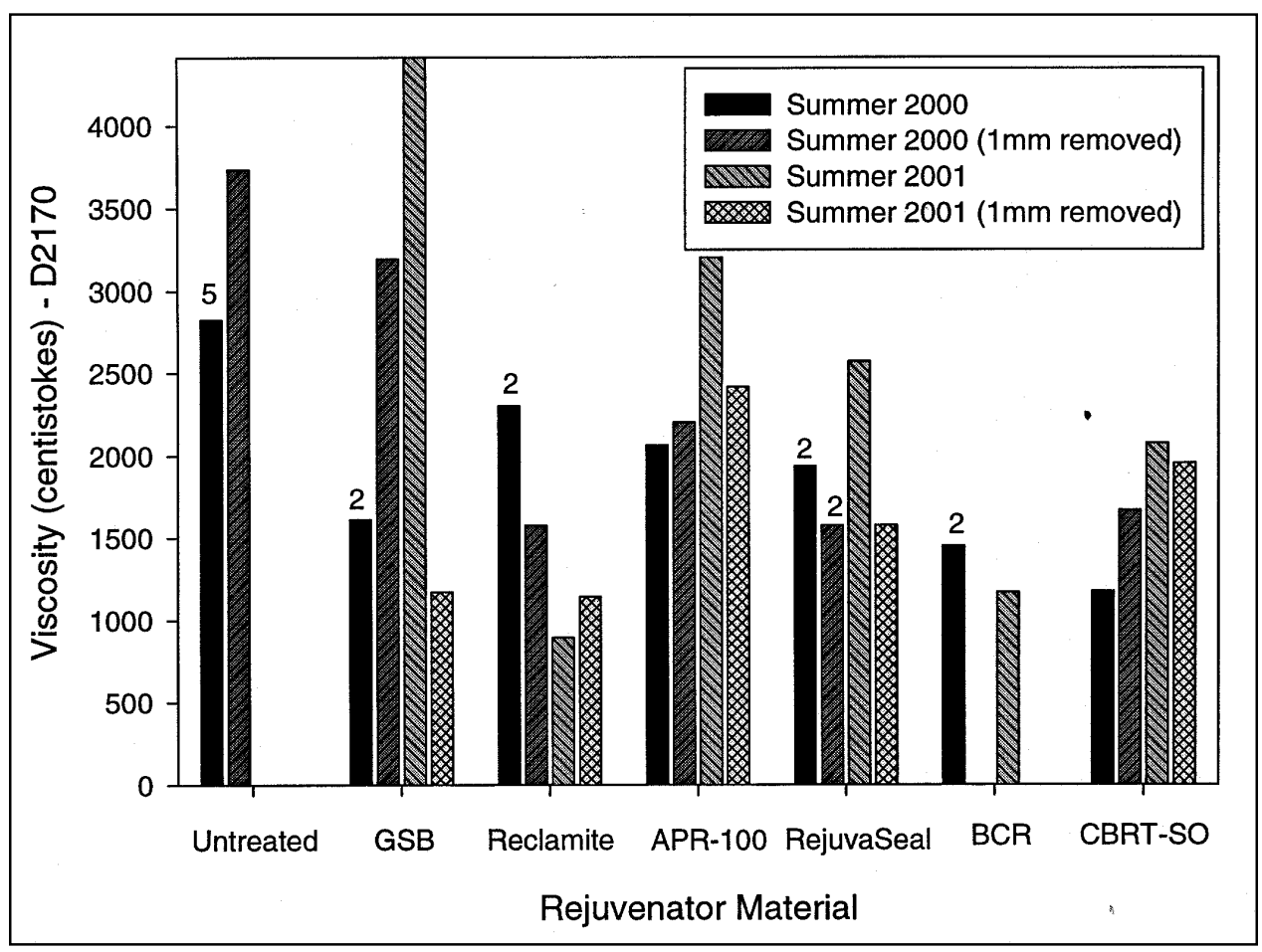

Figure 33. Viscosity test results of extracted asphalt binders from McGuire AFB (Note: Numbers above bars indicate the number of individual tests on which the result is based) 


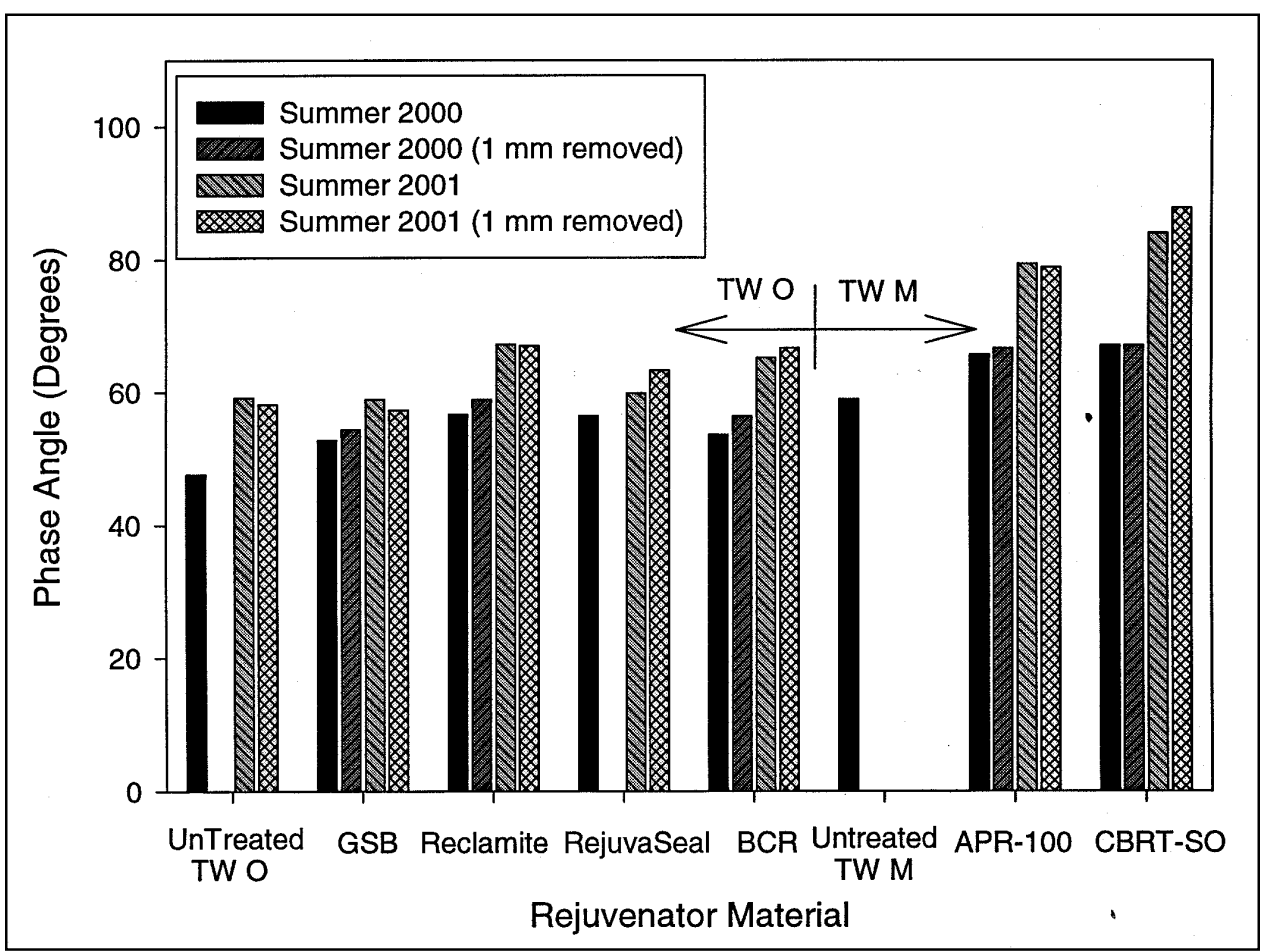

Figure 34. Phase angle test results of extracted binders from MacDill AFB

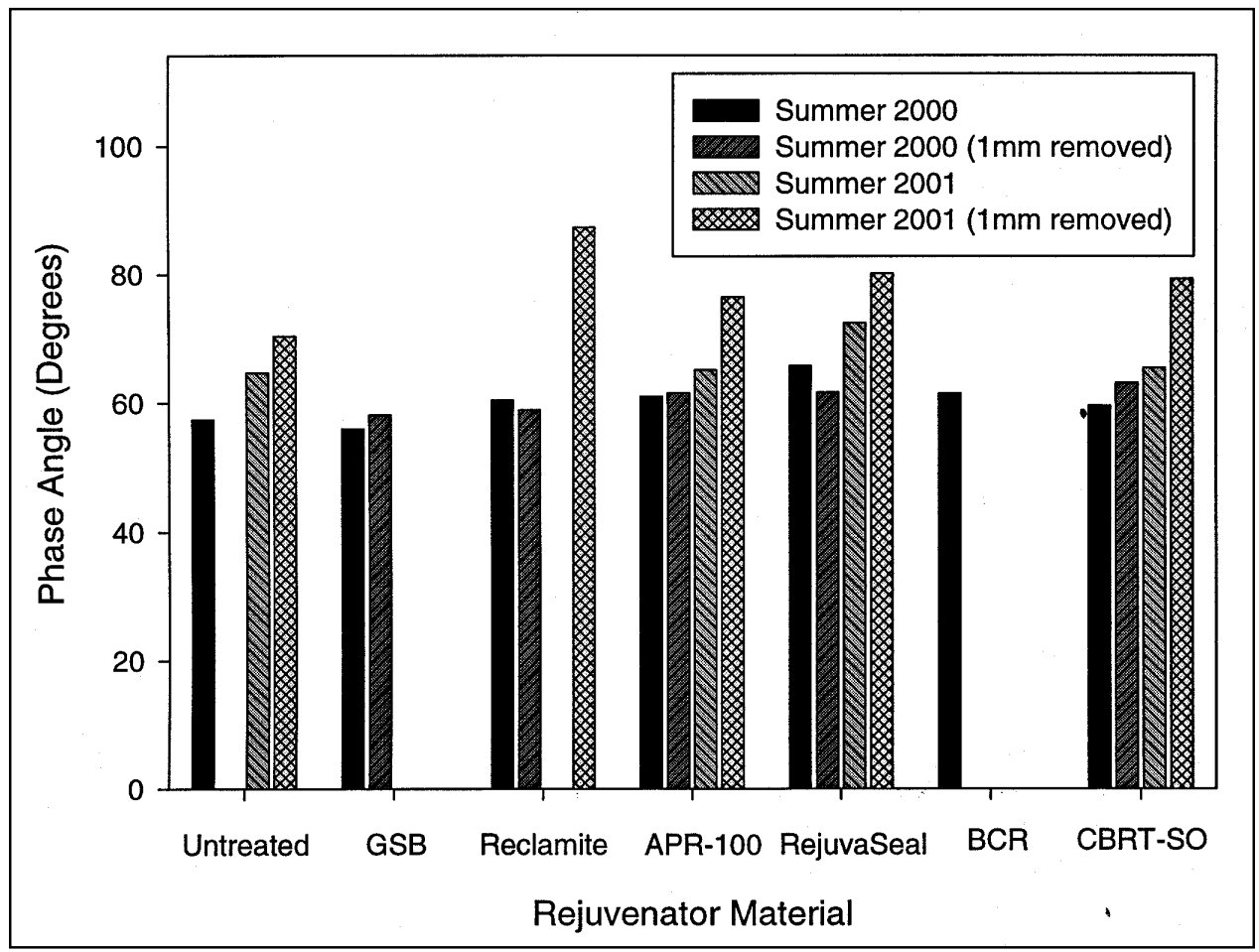

Figure 35. Phase angle test results of extracted binders from McGuire AFB 


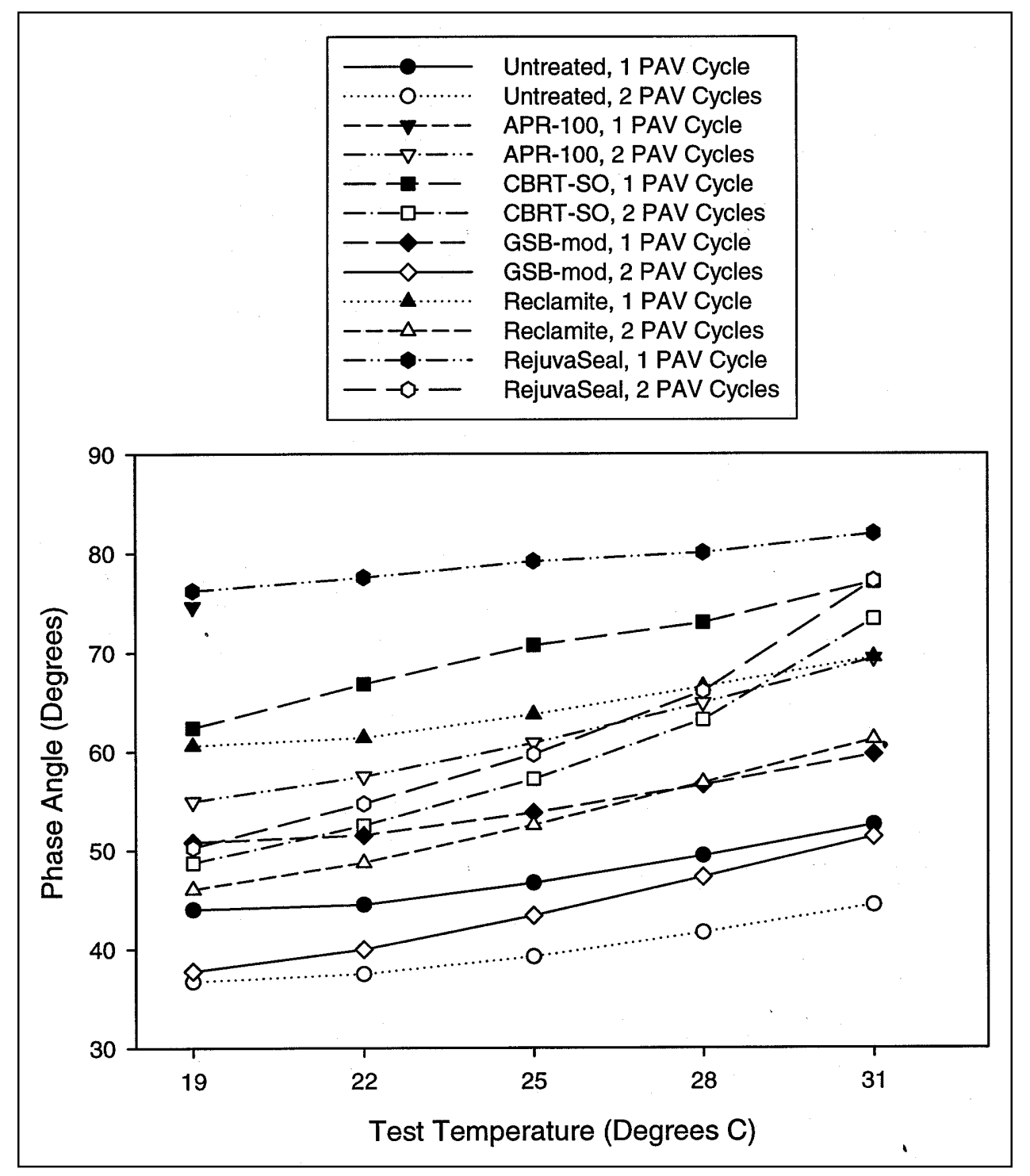

Figure 36. Phase angle values at various temperatures for asphalt binders with a rejuvenator application rate of $0.158 \mathrm{~L} / \mathrm{m}^{2}$ (0.05 gsy) after aging with one or two cycles in a PAV 


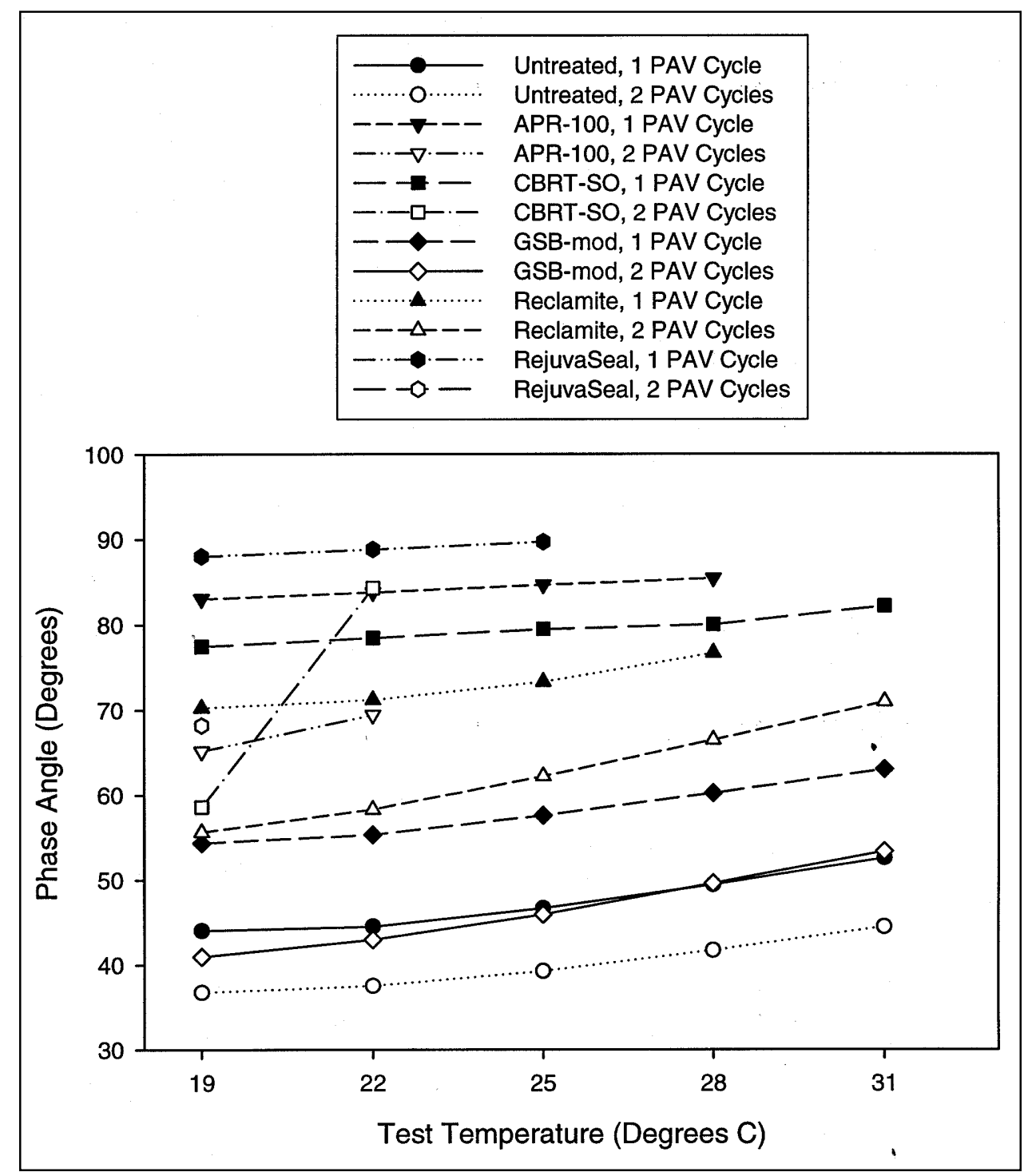

Figure 37. Phase angle values at various temperatures for asphalt binders with a rejuvenator application rate of $0.316 \mathrm{~L} / \mathrm{m}^{2}(0.10 \mathrm{gsy})$ after aging with one and two cycles in a PAV 


\section{Appendix A Fact Sheets}


MATERIAL: AR-2000

DESCRIPTION:

AR-2000 is a proprietary cutback refined coal tar used as a rejuvenator/sealer for hot-mix asphalt (HMA) pavements. According to the manufacturer, the rejuvenator is a combination of refined coal tar, light aromatic solvent naphtha, and coal tar oils. This rejuvenator/sealer deposits a residual coating of coal tar on the pavement surface that provides a degree of fuel resistance. AR-2000 is manufactured by Vision Manufacturing/Protective Barriers Incorporated, 350 Wentworth Street North, Hamilton, Ontario, Canada, telephone: (905) 527-3458, fax: (905) 527-0606. A manufacturing facility is located in Cheektowaga, NY.

\section{AREAS OF APPLICATION:}

AR-2000 is manufactured for application to the surface of any HMA pavement to rejuvenate the aged or oxidized asphalt cement binder. The residual coal tar deposited on the pavement surface can provide at least some short-term fuel resistance, as evidenced by the results of this study and data supplied by the manufacturer. The length of time that the rejuvenator/sealer provides fuel resistance will probably be reduced with traffic.

\section{PHYSIOGRAPHIC FACTORS:}

AR-2000 can be applied with a bituminous distributor or other bituminous spray devices. The normal application rate can vary from 0.01 to $0.02 \mathrm{~L} / \mathrm{sq} \mathrm{m}$ ( 0.04 to $0.08 \mathrm{gal} / \mathrm{sq} \mathrm{yd})$, depending upon the condition of the pavement surface. The HMA pavement to be treated should be clean and dry and the pavement temperature should be a minimum of $10^{\circ} \mathrm{C}\left(50^{\circ} \mathrm{F}\right)$. According to the manufacturer the maximum spray application temperature is $35^{\circ} \mathrm{C}\left(95^{\circ} \mathrm{F}\right)$. The shelf life is indefinite when stored in a sealed container; however, long-term storage will require periodic agitation or intensive agitation prior to application. The material requires no dilution or preparation other than agitation prior to use. The cost will vary with the geographic location and the amount used in the project. This rejuvenator/sealer contains coal tar and protective eyewear and clothing should be worn, and prolonged breathing of vapors should be avoided when handling or placing the material.

DISCUSSION AND RECOMMENDATION (Previous use and this study):

According to the manufacturer, this rejuvenator/sealer has been manufactured since 1999 and applied to numerous commercial airfield pavements and industrial properties throughout Canada and the United States. The results of this study from McGuire AFB indicated that the application of the material resulted in a reduction of skid resistance of about 20 to 40 percent versus the untreated areas. This product was only placed at McGuire AFB; therefore, these results are based on British Pendulum and Saab Friction Tester results. Results supplied by the manufacturer of test sections applied to a runway in Canada showed minimal losses in skid resistance when measured with a Saab Friction Tester. Grip Tester results for this study are not available to adequately judge whether the skid resistance of the pavement is below acceptable levels. 
The manufacturer recommends skid testing both prior to and after application to high-speed traffic areas.

\section{SUMMARY:}

AR-2000 was effective at rejuvenating (lowering the viscosity) the asphalt cement binder in the HMA pavements treated for this study. The rejuvenator did reduce the skid resistance of the pavement. Prior to usage on any high-speed pavement application, test sections for evaluation of application rates are required to assure adequate skid resistance after application. 
MATERIAL: APR-100

DESCRIPTION:

Asphalt Pavement Rejuvenator (APR) is a 100 percent petroleum component asphalt pavement rejuvenator. APR-100 is manufactured by E. A. Mariani Asphalt Company, Inc., 5201 Causeway Boulevard, Tampa, FL 33675-0437, telephone (813) 623-3941, fax (813) 626-4103, email

marianiasphalt@compuserve.com.

AREAS OF APPLICATION:

APR-100 can be applied to the surface of any asphalt pavement to rejuvenate the aged or oxidized asphalt cement binder. Surfaces previously sealed with other products should be evaluated with test sections of APR-100 to ensure compatibility.

\section{PHYSIOGRAPHIC FACTORS:}

APR-100 is best applied with a specialized bituminous spray applicator that is designed to apply sealer rejuvenator materials. Normal bituminous distributors will not apply the material without modification. Normal application rates of 0.01 to $0.02 \mathrm{~L} / \mathrm{sq} \mathrm{m}(0.04$ to $0.08 \mathrm{gal} / \mathrm{sq} \mathrm{yd})$ are used, depending upon pavement surface conditions. The material should be applied at ambient temperature or heated to a maximum temperature of $38^{\circ} \mathrm{C}\left(100^{\circ} \mathrm{F}\right)$. The manufacturer recommends making small pavement test areas and applying various amounts of the rejuvenator to determine an optimum application rate.

The manufacturer claims APR-100 will penetrate the asphalt pavement up to a depth of 3.2 to $4.8 \mathrm{~mm}$ (1/8 to 3/16 in.) and will be compatible with all paving grade asphalt cement binders. The material can be applied as delivered, and it has an unlimited shelf life provided it is stored in a sealed container. Prior to use and during application, it should be circulated. According to the manufacturer, the estimated cost is $\$ 1.50 / \mathrm{sq} \mathrm{m}(\$ 1.25 / \mathrm{sq} \mathrm{yd})$. As with any petroleum-based system, adequate ventilation is required, and protective eyewear and clothing should be worn.

DISCUSSION AND RECOMMENDATION (Previous use and this study):

According to the manufacturer, this product is relatively new with a few field test sections in place for about 4 year, and no skid testing has been accomplished. Based on the results of this study, this product was able to rejuvenate the asphalt cement binder of the pavements to which it was applied. Over time (within a few months) the pavement surface to which it was applied lightened from the original black color, as it left very little residual material on the surface. Evaluation of the test sections for this study showed that APR-100 was effective at increasing the penetration and decreasing the viscosity of the asphalt cement binder in the treated pavement. The application of the rejuvenator somewhat decreased the skid resistance of the pavement surface; however, in this study the reduction was not below acceptable levels for high-speed traffic. This effect will probably vary 
with different pavements and should be investigated prior to using it for runway applications.

\section{SUMMARY:}

APR-100 was effective at rejuvenating (lowering the viscosity) the asphalt cement binder in the HMA pavements treated for this study. The rejuvenator did somewhat reduce the skid resistance of the pavement, although not below acceptable levels. 
MATERIAL: BCR-2000 / BCR-3000

\section{DESCRIPTION:}

BCR-2000 and BCR-3000 are proprietary cutback materials used as rejuvenator/sealers for hot-mix asphalt (HMA) pavements. According to the manufacturer, the rejuvenators are a combination of refined coal tar, coal tar oils, and petroleum rejuvenating agents. BCR-3000 contains more petroleum rejuvenating agent material than BCR-2000. Both of these rejuvenator/sealers deposit a residual coating of coal tar on the pavement surface that provides a degree of fuel resistance. The rejuvenator/sealers are manufactured by Pavement Depot Inc., 131 Willow St., Cheshire, CT 06410, telephone: (203) 272-3221, fax: (203) 271-3396.

\section{AREAS OF APPLICATION:}

The BCR materials can be applied to the surface of any HMA pavement to rejuvenate the aged or oxidized asphalt cement binder. The residual deposit of coal tar would provide at least some short-term fuel resistance for parking and maintenance areas. The length of time that the rejuvenator/sealer provides fuel resistance will be reduced with traffic. The manufacturer states that the rejuvenator/sealer has been used as a tack coat to reduce reflective cracking, waterproof the treated pavement surface, and provide a strong effective bond for the overlay.

\section{PHYSIOGRAPHIC FACTORS:}

The BCR materials can be applied with a bituminous distributor or other bituminous spray devices. The rate of application will normally range between 0.01 to $0.02 \mathrm{~L} / \mathrm{sq} \mathrm{m}(0.04$ to $0.08 \mathrm{gal} / \mathrm{sq} \mathrm{yd})$, depending on the condition of the pavement surface. Dense-graded pavements would not require as much rejuvenator as open-graded pavements. Softer (lower viscosity) asphalts in colder climates would also require less rejuvenator. Raveled or open-graded surfaces would require the upper application rate. The HMA pavement to be treated should be clean and dry, and the pavement temperature should be a minimum of $10^{\circ} \mathrm{C}\left(50{ }^{\circ} \mathrm{F}\right)$. The rejuvenator/sealer deposits a residual coating of coal tar on the pavement surface that provides a degree of fuel resistance. For high-speed applications, the manufacturer recommends placing a hard fine (sandsized) aggregate on top of the uncured BCR materials to provide for satisfactory short-term skid resistance. The manufacturer provides a 3-year warranty on the performance of the rejuvenator/sealer material. The manufacturer recommends reapplication of the rejuvenator/sealer every 3 to 5 years on heavy traffic areas and every 5 to 7 years on lower traffic areas.

This rejuvenator/sealer contains coal tar, and protective eyewear and clothing should be worn. Prolonged breathing of vapors should be avoided when handling or placing the material. According to the manufacturer, the product is normally applied as delivered and at ambient temperature. The HMA pavement to be treated should be clean and dry, and the pavement temperature should be a minimum of $10^{\circ} \mathrm{C}\left(50^{\circ} \mathrm{F}\right)$. The product has no practical shelf life limitation; it can be readily stored over a winter season. Cost is, of course, based on the 
application rate and the size of the project, with a general cost range of from $\$ 0.50$ to $\$ 0.75 /$ sq m $(\$ 0.60$ to $\$ 0.90 /$ sq yd)

DISCUSSION AND RECOMMENDATION (Previous use and this study):

The results of this study showed that the product was able to rejuvenate (decrease the viscosity) the asphalt cement binder of the pavements to which it was applied. During the year that the treated pavement surface was evaluated, it retained its black color, and a substantial amount of residual material remained on the surface.

According to the manufacturer, this rejuvenator/sealer has been applied to numerous military and commercial airfield pavements in the U.S. and Canada. Data obtained from the manufacturer and from other sources concerning skid testing showed that after application of the material, a reduction in skid resistance of up 10 percent was possible. With the addition of fine aggregate, the skid resistance remained on average similar to the untreated areas.

The results of this study from MacDill AFB indicated that the application of the material resulted in skid loss values of about 45 to 55 percent without aggregate. However, with the addition of aggregate skid, the loss was less than 10 percent of the untreated pavement. The results from McGuire AFB indicated only a 10 to 15 percent skid loss without aggregate, and the addition of aggregate increased it over the untreated areas. The results of these skid tests, with the exception of the nonaggregate sections at MacDill AFB, were all above accepted minimum levels of performance. The manufacturer recommends skid testing both prior to and after application.

\section{SUMMARY:}

The BCR materials were effective at rejuvenating (lowering the viscosity) the asphalt cement binder in the HMA pavements treated for this study. The rejuvenator did somewhat reduce the skid resistance of the pavement, although not below acceptable levels, when applied as recommended by the manufacturer. 


\section{MATERIAL: CBRT-SO}

\section{DESCRIPTION:}

CBRT-SO is a proprietary cutback refined coal tar used as a rejuvenator/ sealer for hot-mix asphalt (HMA) pavements. This rejuvenator/sealer deposits a residual coating of coal tar on the pavement surface that provides a degree of fuel resistance. CBRT-SO is manufactured by E. A. Mariani Asphalt Company, Inc., 5201 Causeway Boulevard, Tampa, FL 33675-0437, telephone: (813) 623-3941, fax: (813) 626-4103, email marianiasphalt@compuserve.com.

\section{AREAS OF APPLICATION:}

CBTR-SO can be applied to the surface of any HMA pavement to rejuvenate the aged or oxidized asphalt cement binder. Surfaces previously sealed with other products should be evaluated with test sections of CBRT-SO to ensure compatibility. The residual deposit of coal tar would provide at least some shortterm fuel resistance for parking and maintenance areas. The length of time that the rejuvenator/sealer provides fuel resistance is reduced with traffic.

\section{PHYSIOGRAPHIC FACTORS:}

According to the manufacturer, CBTR-SO is best applied with a specialized bituminous spray applicator that is designed to apply sealer rejuvenator materials. Normal bituminous distributors will not apply the material without modification. CBRT-SO is applied with a bituminous distributor, normally at a rate of 0.01 to $0.02 \mathrm{~L} / \mathrm{sq} \mathrm{m}(0.05$ to $0.10 \mathrm{gal} / \mathrm{sq} \mathrm{yd})$, depending upon pavement surface conditions. The HMA pavement to be treated should be clean and dry, and the pavement temperature should be at least $10^{\circ} \mathrm{C}\left(50^{\circ} \mathrm{F}\right)$. The rejuvenator/sealer can be applied at ambient temperature or heated to a temperature between $27 \pm 6{ }^{\circ} \mathrm{C}$ $\left(80 \pm 10^{\circ} \mathrm{F}\right)$, with $38^{\circ} \mathrm{C}\left(100^{\circ} \mathrm{F}\right)$ as the maximum allowable temperature. The manufacturer recommends applying various amounts of the material to test areas on the pavement to determine an optimum application rate.

The material can be applied as delivered, and it has an unlimited shelf life, provided it is stored in a sealed container. Prior to use and during application, it should be circulated. According to the manufacturer, the estimated cost range is from $\$ 0.90$ to $\$ 1.50 / \mathrm{sq} \mathrm{m}$ ( $\$ 0.75$ to $\$ 1.25 / \mathrm{sq}$ yd). This rejuvenator/sealer contains coal tar, and protective eyewear and clothing should be worn, and prolonged breathing of vapors should be avoided when handling or placing the material.

DISCUSSION AND RECOMMENDATION (Previous use and this study):

The results of this study showed that the product was able to rejuvenate (decrease the viscosity) the asphalt cement binder of the pavements to which it was applied. During the year that the treated pavement surface was evaluated, it retained its black color, and a substantial amount of residual material remained on the surface. 
According to the manufacturer, CBRT-SO has been used as a rejuvenator/ sealer on HMA pavements for more than 6 years. CBRT-SO has been used on several civilian airports and one military airfield (Pensacola Naval Air Station). Data from the manufacturer for projects at two civilian airports in the fall of 2001 show the material providing acceptable skid resistance. According to the manufacturer, he will provide detailed references concerning various projects and test results including skid resistance testing upon request.

The results of this study from McGuire AFB with the Grip Tester indicated that the application of the material reduced the skid resistance values by less than 10 percent and the addition of aggregate increased it over the untreated areas. However, the results from MacDill AFB were very different, showing skid loss values of almost 50 percent and even with the addition of aggregate skid the loss was almost 45 percent. The results of these skid tests, with the exception of those from MacDill AFB on the nonsanded section, were all above accepted minimum levels of performance. The British pendulum and Saab Friction Tester values followed the same general trend of the Grip Tester results, although the loss in skid resistance was more substantial at McGuire AFB but less substantial at MacDill AFB. The manufacturer recommends skid testing both prior to and after application.

\section{SUMMARY:}

CBRT-SO was effective at rejuvenating (lowering the viscosity) the asphalt cement binder in the HMA pavements treated for this study. The rejuvenator did somewhat reduce the skid resistance of the pavement, although not below acceptable levels 
MATERIAL: CPR

DESCRIPTION:

CPR is a proprietary cutback refined coal tar used as a rejuvenator/sealer for hot-mix asphalt (HMA) pavements. This rejuvenator/sealer deposits a residual coating of coal tar on the pavement surface that provides a degree of fuel resistance. This rejuvenator/sealer is manufactured by Reeves Enterprises, Inc., 899 River Road, Selkirk, NY 12158, telephone: (215) 497-0024, fax: (561) 658-2607.

\section{AREAS OF APPLICATION:}

CPR can be applied to the surface of any HMA pavement to rejuvenate the aged or oxidized asphalt cement binder. The residual deposit of coal tar would provide at least some short-term fuel resistance for parking and maintenance areas. The length of time that the rejuvenator/sealer provides fuel resistance is reduced with traffic.

\section{PHYSIOGRAPHIC FACTORS:}

CPR can be applied with a bituminous distributor, normally at a rate of 0.01 to $0.02 \mathrm{~L} / \mathrm{sq} \mathrm{m}(0.04$ to $0.08 \mathrm{gal} / \mathrm{sq} \mathrm{yd})$, depending upon pavement surface conditions. The HMA pavement to be treated should be clean and dry, and the pavement temperature should be at least $10^{\circ} \mathrm{C}\left(50^{\circ} \mathrm{F}\right)$. A typical application temperature for the rejuvenator/sealer is $32 \pm 6{ }^{\circ} \mathrm{C}\left(90 \pm 10^{\circ} \mathrm{F}\right)$. According to the manufacturer, the minimum residue content of the rejuvenator is 55 percent. The manufacturer recommends applying various amounts of the material to test areas on the pavement to determine an optimum application rate.

This rejuvenator/sealer contains coal tar, and protective eyewear and clothing should be worn. Prolonged breathing of vapors should be avoided when handling or placing the material. According to the manufacturer, the product is normally applied as delivered. The product has no practical shelf life limitation; it can be readily stored over a winter season. Cost is, of course, based on the application rate and the size of the project, with a typical cost of about $\$ 0.84 / \mathrm{sq} \mathrm{m}(\$ 1.00 / \mathrm{sq}$ yd).

DISCUSSION AND RECOMMENDATION (Previous use and this study):

The results of this study showed that the product was able to rejuvenate (decrease the viscosity) the asphalt cement binder of the pavements to which it was applied. During the time that the treated pavement surface was evaluated, it retained its black color, and a substantial amount of residual material remained on the surface.

Data obtained from the manufacturer concerning skid testing showed that after application of the material a reduction in skid resistance of 10 percent or more was possible. The manufacturer does not recommend the application of aggregate for maintaining skid resistance. The results of this study from McGuire AFB indicated that the application of the material reduced the skid 
resistance of the pavement versus untreated areas. The results showed skid loss values up to about 40 percent, with the British Pendulum; however, these results closely followed other coal tar based rejuvenators without applications of surface aggregate. The results of the skid tests with the Grip Tester showed that the levels achieved at the time of testing were all above accepted minimum levels of performance.

\section{SUMMARY:}

CPR was generally effective at rejuvenating (lowering the viscosity) the asphalt cement binder in the HMA pavements treated for this study. The rejuvenator did somewhat reduce the skid resistance of the pavement, although not below acceptable levels. 


\section{MATERIAL: GSB-mod}

\section{DESCRIPTION:}

GSB-mod is a proprietary rejuvenating emulsion containing petroleum components and Gilsonite for application to hot-mix asphalt (HMA) pavements. GSB-mod is manufactured by Asphalt Systems, Inc., P.O. Box 25511, Salt Lake City, UT, telephone: (801) 972-2757, fax: (801) 972-6433.

\section{AREAS OF APPLICATION:}

GSB-mod can be applied to the surface of any HMA pavement to rejuvenate the aged or oxidized asphalt cement binder and seal the pavement surface. The GSB-mod deposits a residual material on the pavement surface and the manufacturer recommends the addition of a sand aggregate for all applications.

\section{PHYSIOGRAPHIC FACTORS:}

GSB-mod can be applied with a bituminous distributor or any bituminous spray device, at a rate dependent upon pavement surface conditions. The emulsion, as supplied by the manufacturer should be diluted with an equal amount of water prior to application. The manufacturer recommends making small pavement test areas and applying various amounts of the rejuvenator to determine an optimum application rate. GSB-mod is designed to penetrate the HMA pavement surface and will be compatible with all paving grade asphalt cement binders. Protective eyewear and clothing should be worn when working with the GSBmod emulsion. The normal application temperature of GSB-mod is 49 to $71{ }^{\circ} \mathrm{C}$ $\left(120\right.$ to $\left.160^{\circ} \mathrm{F}\right)$. The shelf life of the material can be up to 1 year and require only moderate agitation for use, provided it is not exposed to temperature extremes. Depending upon the size and location (in relationship to a dealership) of the project, the in-place cost will typically range from $\$ 0.60$ to $\$ 0.95$ per sq $\mathrm{m}$ $(\$ 0.50$ to $\$ 0.80$ per sq yd).

\section{DISCUSSION AND RECOMMENDATION:}

Except for this study, previous history of the use of this product is limited to extensive Department of Transportation (DOT) use in some Western States and other smaller civilian markets. GSB-mod has been in use for about 6 years. The results of this study showed that the product was able to rejuvenate (decrease the viscosity) the asphalt cement binder of the pavements to which it was applied. During the year that the treated pavement surface was evaluated it retained its black color, and there was a substantial amount of residual material on the surface. The GSB-mod was applied with sand-sized aggregate, and no decrease in the skid resistance of the pavement surface was observed when compared with control sections.

\section{SUMMARY:}

GSB-mod was generally effective at rejuvenating (lowering the viscosity) the asphalt cement binder in the HMA pavements treated for this study. The 
rejuvenator, with the standard application of aggregate, did not reduce the skid resistance of the treated pavement. 
MATERIAL: Reclamite ${ }^{\circledR}$

\section{DESCRIPTION:}

Reclamite is a rejuvenating cationic maltene emulsion that is applied to an existing hot-mix asphalt (HMA) pavement with a bituminous distributor. Reclamite, developed more than 35 years ago, was acquired in July 2001 by Tricor Refining, LLC, Bakersfield, CA., contact: Keith Ryan, (480) 940-9500, Copper State Emulsions. Selected licensees throughout the United States now manufacture Reclamite.

\section{AREAS OF APPLICATION (AS RECOMMENDED BY PRODUCER):}

1. Bituminous rejuvenator.

2. Bituminous construction seal (seal applied to newly paved HMA pavements).

3. Rejuvenator used during hot and/or cold bituminous pavement recycling.

\section{PHYSIOGRAPHIC FACTORS:}

Reclamite concentrate is normally mixed two parts Reclamite to one part water and applied at ambient temperature. Since Reclamite is an emulsion, it can be applied to a damp surface. However, care must be taken to ensure that the pavement is not too wet for the emulsion to break properly and penetrate into the pavement. Reclamite should be placed when the ambient temperature is above $40{ }^{\circ} \mathrm{F}$; however, warmer temperatures are desired, because the material will penetrate deeper into the pavement and will break and cure faster.

Reclamite has to penetrate into the pavement to perform. Therefore, any pavement that exhibits flushing or bleeding and/or rutting or shoving should not be treated. Reclamite should not be applied to slurry seals or single or double bituminous surface treatments, unless they are at least several years old and exhibit a dry, oxidized surface. Before applying Reclamite to a pavement surface, a small test section (approximately 20-30 sq m (sq yd)) should be constructed to determine the maximum amount that can be absorbed into the pavement. According to the manufacturer, the Reclamite should be absorbed within $45 \mathrm{~min}$.

The application of any petroleum material to the surface of a pavement, without the addition of aggregate, will cause a reduction in skid resistance. Reclamite will cause a reduction in skid resistance when it is applied to a pavement surface; however, at the proper application rate, the lower skid resistance is only for a relatively short period of time. Extreme care should be exercised when applying Reclamite to areas such as runways, curves on high-speed roads, dangerous intersections, etc., where even a temporary reduction in skid resistance would be extremely dangerous. 
DISCUSSION AND RECOMMENDATIONS (Previous use and this study):

General. When properly used, Reclamite has shown benefits as a pavement maintenance material. There are some important factors to consider when using Reclamite:

1. Reclamite will soften asphalt binder, increase the penetration, and lower the viscosity.

2. When applied to an asphalt concrete pavement surface, Reclamite will lower (at least temporarily) pavement skid resistance. When all the material does not penetrate into the pavement, the excess should be blotted with sand and broomed.

3. When Reclamite is added to a pavement, the air-void content will be lowered, thus reducing the permeability of the pavement.

4. Reclamite should have no adverse effect on snow or ice removal operations.

5. Pavements treated with Reclamite should be closed to traffic until the emulsion has been absorbed into the pavement, usually less than $1 \mathrm{hr}$. An application of sand will trafficking after the 1-hr cure period. Runways and other pavement areas where sanding is not practical should be closed to traffic for 12 to $24 \mathrm{hr}$ to allow the Reclamite to penetrate and cure.

Bituminous Rejuvenator. Reclamite has demonstrated an effectiveness at partially rejuvenating old oxidized pavements. Reclamite will penetrate the pavement and lower the viscosity and raise the penetration of the oxidized asphalt binder. Reclamite ( $2: 1$ solution) is normally applied at an application rate of 0.15 to $0.90 \mathrm{~L} / \mathrm{sq} \mathrm{m}(0.03$ to $0.20 \mathrm{gal} / \mathrm{sq} \mathrm{yd})$. Prior to treating a pavement with Reclamite, a test section at three or four application rates should be constructed and observed for 45 to 60 min to ensure that the selected application rate of Reclamite will penetrate into the pavement.

Previous research has shown that asphalt pavement treated with Reclamite will remain softer than untreated asphalt for at least 3 years of service. Reclamite also helped retain the surface fines and lower the amount of additional cracking (Brown and Johnson 1976). The manufacturer states that since 1972 Reclamite has been successful on projects requiring a specified level of rejuvenation.

A most beneficial use of Reclamite would be in preventive maintenance. Bituminous pavements which have a high air-void content (above 7 percent) could be treated with a small, diluted application ( 0.05 to 0.07 gsy) of Reclamite periodically (yearly) until the pavement surface is sealed sufficiently to prevent penetration of Reclamite into the pavement (Brown and Johnson 1976). According to the manufacturer, pavements with lower air voids could also be treated; however, proper testing and application and dilution rate would be required. Application of the rejuvenator in this manner should help eliminate excessive oxidation of the asphalt concrete pavement which, in turn, would keep cracking and raveling to a minimum. 
Bituminous Construction Seal (According to the manufacturer). Reclamite is applied shortly (1 week to 9 months) after placement of a HMA pavement primarily to counteract the loss of maltene fractions caused by heat during mixing and placement. As with any application of a rejuvenator, the proper application rate must be determined and consideration given to its effect on skid resistance.

A properly designed and constructed pavement will not need a seal immediately after construction. According to the manufacturer, cities like Orlando, FL, Cleveland, OH, and Tampa, FL, have been applying Reclamite to their new pavements for more than 15 years and they report that an independent study by Orlando confirmed this procedures effectiveness.

Rejuvenator Used in Hot and Cold Recycling (According to the manufacturer). Reclamite has been used since the mid 1960's in hot surface recycling operations. In this process, the Reclamite replaces missing maltene fractions in the old oxidized pavement and counters some of the damage caused during the heating of the pavement. The manufacturer states that, since the early 1970 s, another product Cyclogen is often used for this recycling process and cold recycling processes. The manufacturer states that nomographs have been developed to select amounts, and the type of material that should be selected for the particular pavement to be recycled.

\section{SUMMARY:}

Reclamite is a material that can be used in maintenance of asphalt concrete pavements. Care must be taken, however, in selecting pavements to be treated. In general, when Reclamite is used, the asphalt binder will be softened (become less brittle). The skid resistance will be lowered when Reclamite is applied to the pavement surface; however, this effect maybe significant for only a few days, depending upon the application rate and climatic conditions.

\section{REFERENCES:}

Brown, E. R., and Johnson, R. R. (1976). "Evaluation of rejuvenators for bituminous pavements," Technical Report No. AFREC-TR-76-3, U.S. Air Force Civil Engineering Center, Tyndall AFB, Florida.

Fish, C. W., and Potts, C. F. (1972). "Reduction of reflective cracking in bituminous overlays, Payne's Prairie Experimental Project," Report No. 176, Florida Department of Transportation.

Lindley, B. R. (1975 (Oct)). "Cold recycling of asphalt concrete pavement," Report No. 613-1, Texas Department of Highways and Public Transportation.

Predoehl, N. H., and Kemp, G. R. (1974). "Copperopolis test section binder modifiers and construction seals," Interim Report No. CA-DOT-TL-3105-1-7435, California Department of Transportation. 
MATERIAL: RejuvaSeal N / RejuvaSeal 50 / RejuvaSeal 500

\section{DESCRIPTION:}

RejuvaSeal is a proprietary cutback refined coal tar used as a rejuvenator/ sealer for hot-mix asphalt (HMA) pavements. RejuvaSeal, according to the manufacturer, is a mixture of RT-12, petroleum distillates, and rejuvenator materials. According to the manufacturer, RejuvaSeal $\mathrm{N}$ is the standard rejuvenator/sealer product; the other products are similar except for increased amounts of petroleum distillates. This rejuvenator/sealer is manufactured by Echelon Industries Incorporated, 2557 Glenn Drive, Canyon Lake, TX 78133, telephone: (830) 899-8527, fax: (830) 899-8541.

\section{AREAS OF APPLICATION:}

RejuvaSeal can be applied to the surface of any HMA pavement to rejuvenate the aged or oxidized asphalt cement binder. The material should only be applied to pavements in satisfactory structural condition. The residual deposit of coal tar would provide fuel resistance for parking and maintenance areas. The length of time that the rejuvenator/sealer provides fuel resistance would appear to be dependent the amount of traffic applied, probably decreasing with increased traffic. According to the manufacturer, the fuel resistance provided by the rejuvenator/sealer is warranted for a minimum of 3 years, as stated below.

\section{PHYSIOGRAPHIC FACTORS:}

The rejuvenator/sealer deposits a residual coating of coal tar on the pavement surface that provides a degree of fuel resistance. RejuvaSeal can be applied with a bituminous distributor or other bituminous spray devices. The rate of application will normally range between 0.01 to $0.02 \mathrm{~L} / \mathrm{sq} \mathrm{m}(0.04$ to $0.08 \mathrm{gal} / \mathrm{sq} \mathrm{yd})$, depending on the type and condition of the pavement surface. Dense-graded pavements would not require as much rejuvenator as open-graded pavements. Softer (lower viscosity) asphalts in colder climates would also require less rejuvenator. Raveled or open-graded surfaces would require the upper application rate. For military high-speed applications, the manufacturer recommends application of a special grade of hard fine aggregate at a rate of 0.5 to $1.0 \mathrm{lb} / \mathrm{sq} \mathrm{m}$ $(0.5$ to $1.0 \mathrm{lb} / \mathrm{sq} \mathrm{yd})$ on top of the uncured RejuvaSeal to provide for satisfactory short-term skid resistance. The manufacturer provides a 3-year warranty on the performance of the rejuvenator/sealer material. The manufacturer recommends reapplication of the rejuvenator/sealer every 5 to 7 years.

This rejuvenator/sealer contains coal tar, and protective eyewear and clothing should be worn. Prolonged breathing of vapors should be avoided when handling or placing the material. According to the manufacturer, the product is normally applied as delivered and at ambient temperature. The HMA pavement to be treated should be clean and dry, and the pavement temperature should be a minimum of $10^{\circ} \mathrm{C}\left(50^{\circ} \mathrm{F}\right)$. The product has no practical shelf life limitation; it can be readily stored over a winter season. Cost is of course based on the application rate and the size of the project. The manufacturer recommends for estimating purposes to select the average application rate of $0.016 \mathrm{~L} / \mathrm{sq} \mathrm{m}$ 
$(0.065 \mathrm{gal} / \mathrm{sq} \mathrm{yd})$ and selecting a project with an area of about $840,000 \mathrm{sq} \mathrm{m}$ $(100,000 \mathrm{sq} y d)$. This results in an average cost of $\$ 0.54 / \mathrm{sq} \mathrm{m}(\$ 0.65 / \mathrm{sq} \mathrm{yd})$.

DISCUSSION AND RECOMMENDATION (Previous use and this study):

The results of this study showed that the product was able to rejuvenate (decrease the viscosity) the asphalt cement binder of the pavements to which it was applied. During the year that the treated pavement surface was evaluated, it retained its black color, and a substantial amount of residual material remained on the surface.

According to the manufacturer, this rejuvenator/sealer has been applied to more than 150 military and commercial airfield pavements since 1997. It has been placed on airfields in the United States, Canada, and Brazil. Data obtained from the manufacturer and from other sources concerning skid testing showed that after application of the material, a reduction in skid resistance of up to 10 percent was possible. With the addition of fine aggregate, the skid resistance remained on average similar to the untreated areas. The results of this study from McGuire AFB indicated that the application of the material didn't reduce the skid resistance and the addition of aggregate increased it over the untreated areas. The results from MacDill AFB were very different, showing skid loss values of about 45 percent; however, with the addition of aggregate skid, the loss was less than 15 percent. The results of these skid tests, with the exception of those from MacDill AFB, were all above accepted minimum levels of performance. The manufacturer recommends skid testing both prior to and after application.

\section{SUMMARY:}

RejuvaSeal was effective at rejuvenating (lowering the viscosity) the asphalt cement binder in the HMA pavements treated for this study. The rejuvenator did somewhat reduce the skid resistance of the pavement, although not below acceptable levels 
MATERIAL: CRF $^{\circledR}$

\section{DESCRIPTION:}

$\mathrm{CRF}$ is an asphalt-based pavement rejuvenator/sealer. The manufacturer states that CRF is composed of mostly the maltene fractions of asphalt cement with up to 11 percent, by weight, the asphaltenes fraction. According to the manufacturer, the CRF emulsion does not become brittle, but kneads and retains flexibility over time and provides some rejuvenation to the pavement. CRF is a cationic (positive charge) emulsion. CRF is a product of Tricor Refining LLC, Golden Bear Division, Bakersfield, CA, Contact: Keith Ryan (480) 940-9500. CRF is manufactured by Selected Licenses throughout the U.S.

\section{AREAS OF APPLICATION:}

According to the manufacturer, CRF is applied to weathered asphalt surfaces that exhibit surface raveling and minor cracking. The CRF procedure is called a "Restorative Seal." The CRF procedure is intended to fill any voids or small cracks within the asphalt pavement surface.

\section{PHYSIOGRAPHIC FACTORS:}

$\mathrm{CRF}$ is normally applied with a bituminous distributor at a rate dependent upon pavement surface conditions. The manufacturer states that CRF is intended as a seal coat material for raveled and minor surface cracked asphalt pavements and for oxidized (aged) pavements provide some minor rejuvenation.

According to the manufacturer, the procedure applying CRF, diluted two parts $\mathrm{CRF}$ to one part water, at a rate of 0.3 to $0.7 \mathrm{~L} / \mathrm{sq} \mathrm{m}(0.07$ to $0.15 \mathrm{gal} / \mathrm{sq} \mathrm{yd})$ to the pavement surface. The CRF is applied at ambient temperature. The applied CRF is then worked into the surface with a series of street brooms, rubber tires of a roller or vehicle, or a squeegee. The surface is then covered with sand at about 1.6 to $2.7 \mathrm{~kg} / \mathrm{sq} \mathrm{m}$ ( 3 to $5 \mathrm{lb} / \mathrm{sq} \mathrm{yd}$ ) and then rolled with a rubbertired roller or opened to traffic.

The cost of a CRF Restorative Seal should cost between $\$ 1.15$ and $\$ 1.30 /$ sq $\mathrm{m}$ ( $\$ 0.95$ and $\$ 1.10 / \mathrm{sq}$ yd). CRF can be stored for at least 1 year, provided it is protected from freezing. As with any petroleum-based system, adequate ventilation is required, and protective eyewear and clothing should be worn.

DISCUSSION AND RECOMMENDATION (Previous use and this study):

CRF is a seal-coat product that has been used for a number of years. It has been used in Canada and by numerous state departments of transportation (DOT). The CRF seal coat procedure was not applicable to the taxiways upon which the test sections for this study were placed. A small section was instead placed on an old badly weathered and raveled apron on the south ramp at MacDill AFB. Conclusions about long-term effectiveness of CRF could not be drawn from this small test section after just 1 year of service. 


\section{SUMMARY:}

CRF has been used as a seal coat by various agencies for a number of years. Definite conclusions regarding the performance of CRF for this study cannot be developed at this time. 
MATERIAL: LAS-320

DESCRIPTION:

Liquid Asphalt Sealing (LAS) is an emulsion seal coat material containing 100 percent inorganic acrylic co-polymers. The product is manufactured by Enviroseal Corporation, 1021 SE Holbrook Ct., Port St. Lucie, FL 34952, telephone (561) 335-8225, fax (561) 335-3991.

\section{AREAS OF APPLICATION:}

LAS-320 can be used to seal HMA pavement surfaces from weathering, water intrusion, and it will provide a fuel-resistant pavement surface. According to the manufacturer, the seal coat material can be applied to a HMA pavement under almost any application and concrete pavements.

\section{PHYSIOGRAPHIC FACTORS:}

LAS-320 can be applied with a bituminous distributor, other bituminous spray devices, or with rollers by hand. The sealer is normally diluted with an equal part of water prior to application. The sealer can be applied at rates normally ranging from 0.01 to $0.04 \mathrm{~L} / \mathrm{sq} \mathrm{m}(0.04$ to $0.16 \mathrm{gal} / \mathrm{sq} \mathrm{yd})$, depending upon pavement surface conditions. The sealer is classified as a nonhazardous material by the U.S. Environmental Protection Agency. According to the manufacturer, the product is nontoxic, nonflammable, and environmentally safe. The manufacturer warranties the sealer against failure for 3 years after application.

The cost, of course, will vary with amount of material required and location of the project; the current material cost is about $\$ 450.00$ per 210 -L (55-gal) drum. When skid resistance is important, a sand-sized aggregate can be spread on the treated surface immediately after application. The material is ready for application as delivered and is normally applied at ambient temperature.

\section{DISCUSSION AND RECOMMENDATION:}

The long-term performance (several years) of LAS-320 was not possible, because of the limited length of time of this study. In the slightly more than 1 1 -year time span of this study, the sealer still provides a uniformly black appearance with no noticeable defects.

\section{SUMMARY:}

LAS-320, considering the limited field experience, would appear to provide an acceptable seal coat for aged HMA pavement surfaces. 


\section{MATERIAL: PAS}

\section{DESCRIPTION:}

Penetrating Asphalt Sealant (PAS) a seal coat material that contains, according to the manufacturer, proprietary elastic polymer, ultraviolet light inhibitors, pigment (for black finish), and adhesion promoters in an asphalt binder base. The sealer is solvent based, containing no water, with a solids content of approximately 50 percent. PAS is manufactured by E. A. Mariani Asphalt Company, Inc., 5201 Causeway Boulevard, Tampa, FL 33675-0437, telephone (813) 623-3941, fax (813)626-4103, email: marianiasphalt@compuserve.com.

\section{AREAS OF APPLICATION:}

According to the manufacturer, PAS can be used to seal both new and old HMA pavements. The material is intended be used to seal and HMA pavement surfaces, not requiring rejuvenation, while providing a black finish for pavements needing contrast for airfield pavement markings (paint stripes).

\section{PHYSIOGRAPHIC FACTORS:}

PAS can be applied with a bituminous distributor or any bituminous spray device, at a rate dependent upon pavement surface conditions. According to the manufacturer, the normal application rate is $0.012 \mathrm{~L} / \mathrm{sq} \mathrm{m}(0.05 \mathrm{gal} / \mathrm{sq} \mathrm{yd})$. Prior to application, place test areas with various amounts of material to determine an optimum application rate for the pavement surface. PAS can be applied at ambient temperature or heated to a temperature between $27 \pm 6^{\circ} \mathrm{C}\left(80 \pm 10^{\circ} \mathrm{F}\right)$, with $38^{\circ} \mathrm{C}\left(100^{\circ} \mathrm{F}\right)$ as the maximum allowable temperature. The material can be applied as delivered and it has an unlimited shelf life, provided it is stored in a sealed container. Prior to use and during application, it should be circulated. According to the manufacturer, the estimated cost is about $\$ 1.50 / \mathrm{sq} \mathrm{m}$ $(\$ 1.25 /$ sq yd).

The manufacturer states that PAS is not intended as a rejuvenator, but on highly oxidized (aged) pavements, some minor rejuvenation may occur. The manufacturer claims PAS will penetrate most HMA pavements up to a depth of 3.2 to $4.8 \mathrm{~mm}$ ( $1 / 8$ to $3 / 16 \mathrm{in}$.). As with any petroleum-based material, adequate ventilation is required, and protective eyewear and clothing should be worn when handling the sealer.

\section{DISCUSSION AND RECOMMENDATION (This study):}

The long-term performance (several years) of PAS was not possible, because of the limited length of time of this study. In the slightly more than a 1-year time span for this study, the sealer still provides a uniformly black appearance with no noticeable defects. According to the manufacturer, this is a relatively new product. Field test sections have been in place for only 2 years and they have no skid-resistance test data.

The results of skid testing at McGuire AFB indicated that the application of the material reduced the skid resistance by about 10 percent over the untreated 
areas. The results from MacDill AFB were different, showing skid loss values of about 20 to 30 percent. The results of these skid tests were all above the accepted minimum levels of performance.

\section{SUMMARY:}

PAS, with limited field experience, would appear to be providing an acceptable seal coat for aged HMA pavement surfaces. 
MATERIAL: PolyTar

DESCRIPTION:

PolyTar is a fuel-resistant HMA pavement surface sealer. PolyTar is an emulsified polymer-modified coal-tar material. Unlike most polymer-modified coal-tar emulsions, a coal tar is combined with a high molecular weight polymer prior to the emulsification process. Seven percent by weight of the proprietary polymer is hot-blended into the base coal tar. PolyTar is manufactured by GemSeal, Inc., 5201 Causeway Boulevard, Tampa, FL 33675-0437, telephone (813) 623-3941, fax (813) 626-4103.

\section{AREAS OF APPLICATION:}

PolyTar can be used to seal HMA pavement surfaces from weathering, water intrusion, and most importantly provide a fuel-resistant pavement surface. The material should be considered for high vehicle-turnover traffic parking areas, maintenance areas, and refueling or other areas where fuel spillage is likely to occur.

\section{PHYSIOGRAPHIC FACTORS:}

PolyTar is applied in the same manner and with the same equipment as conventional coal-tar emulsion seal coats. Coal-tar emulsion seal coats are mixed in batches and sprayed or squeegeed onto the pavement surface. During construction, the pavement should contain no ponded water and the surface temperature should be at least $10^{\circ} \mathrm{C}\left(50^{\circ} \mathrm{F}\right)$ and rising. The manufacturer states that the emulsion has a 4-year shelf life, provided it is protected from freezing, extreme heat, and direct sunlight. The mixture the manufacturer recommends for most applications the addition of 5 percent of water by volume and sand between 360 to $600 \mathrm{~g} / \mathrm{L}(3$ to $5 \mathrm{lb} / \mathrm{gal})$ of emulsion. The normal application rate of the PolyTar mixture is 0.024 to $0.036 \mathrm{~L} / \mathrm{sq} \mathrm{m}(0.10$ to $0.15 \mathrm{gal} / \mathrm{sq} \mathrm{yd})$. According to the manufacturer, the estimated cost range is from $\$ 0.90$ to $\$ 1.50 / \mathrm{sq} \mathrm{m}(\$ 0.75$ to $\$ 1.25 / \mathrm{sq} \mathrm{yd}$ ). As with all coal-tar sealers, while they are not considered toxic or hazardous materials, protective eyewear and clothing should be worn, and prolonged breathing of vapors should be avoided when handling or placing the sealer (Stoner 1996).

\section{DISCUSSION AND RECOMMENDATION:}

Coal-tar emulsion seal coats have been used for many years to seal and protect asphalt pavement surfaces from contact with petroleum materials. Because of small voids that usually developed in the surface during curing, coal-tar sealers are normally applied in two coatings to provide assurance of fuel resistance. When used strictly for reasons of fuel resistance, two coatings should be applied; however, for general pavement sealing, the manufacturer applied only a singlecoat application for this study. The addition of sand to the mixture provides suitable skid-resistance values for the sealer.

While coal-tar materials are resistant to petroleum-based materials, historically they have not been very durable. The low durability is related to cracking 
that normally occurs within the first year of application. Research has shown that placing these mixtures in thinner or a single coating may reduce the frequency of this cracking (Shoenberger 2001). Research by the Pavement Coating Technology Center (PCTC) has shown that new HMA pavements sealed to soon (within 45 to 90 days of placement) have a greater tendency to crack than sealed older (1 year or more) HMA pavements. Research with a field application of PolyTar, in a two-coat application, at a relatively high sand loading $(1,200 \mathrm{~kg} / \mathrm{sq} \mathrm{m}$ (10 lb/gal of emulsion)), showed better performance when compared to other conventional polymer modified coal-tar sealers (Shoenberger 2001).

\section{SUMMARY:}

PolyTar is an effective fuel-resistant coal-tar sealer. Although it has shown increased durability in some instances, its long-term durability as a general pavement sealer where fuel resistance is not a requirement is unknown.

\section{REFERENCES:}

Shoenberger, J. E. (2001). "Material properties and characteristics for development of an expert system for coal-tar sealers," Technical Report, TR-0115, U.S. Army Engineering Research and Development Center, Vicksburg, MS.

Stoner, H. R. (1996). "Coal tars and asphaltics," Journal of Protective Coatings and Linings 13(10), 74-97. 


\section{MATERIAL: ANTISKID (PROMAK A)}

\section{DESCRIPTION:}

ANTISKID (using PROMAK A) is a coal-tar-based system designed to provide a high antiskid/friction surfacing for high-speed airfield applications. ANTISKID is manufactured by POSSEHL Spezialbau GmbH, Rheinstra e 19, D-65185 Wiesbaden, Germany.

\section{AREAS OF APPLICATION:}

The ANTISKID system, according to the manufacturer, has been used to surface pavements on more than 100 airports worldwide. This includes meeting the International Civil Aviation Organization (ICAO) standard for the friction coefficient for new pavements at many (40) North Atlantic Treaty Organization (NATO) airfields. The ANTISKID system should be suitable for any high-speed pavement application wherever a high friction and/or fuel-resistant surfacing is required.

\section{PHYSIOGRAPHIC FACTORS:}

The ANTISKID system is a surface treatment in which the coal tar based emulsion, named PROMAK A, is applied to a primed pavement surface and covered with a crushed basalt aggregate at a minimum rate of $10 \mathrm{~kg} / \mathrm{sq} \mathrm{m}$ $(18.4 \mathrm{lb} / \mathrm{sq} \mathrm{yd}$.) and imbedded with a rubber-tired roller. The aggregate contains no fines (material passing a $75 \mu \mathrm{m}$ (No. 200) sieve) and has a maximum particle size of $3.5 \mathrm{~mm}(0.138 \mathrm{in}$.). After the excess aggregate is removed by brooming, an emulsion seal coat (diluted PROMAK A) is applied by a bituminous distributor in two applications. Depending upon condition of the existing pavement surface, a prime coat may be applied, in which the PROMAK A is diluted with an equal amount of water. The total thickness of the cured surfacing is normally 3 to $4 \mathrm{~mm}(0.12$ to $0.16 \mathrm{in}$.). According to the manufacturer, the normal surface texture depth measurement of the ANTISKID by the grease patch method is $1.8 \mathrm{~mm}(0.07 \mathrm{in}$.).

PROMAK A contains coal-tar pitch. Protective eyewear and clothing should be worn by personnel directly involved in the distributing process of the emulsion. Prolonged breathing of vapors should be avoided when handling or placing the material. The PROMAK A may be stored for 1 year or more when protected from freezing or excessively high temperatures. The emulsion will require mixing to recombine components prior to use.

According to the manufacturer, the cost of the antiskid system depends upon the size, location, and working conditions (day or night) of the project. However, the price to seal a $1,830-\mathrm{m}(6,000-\mathrm{ft})$-long and $45.7-\mathrm{m}(150-\mathrm{ft})$-wide runway would be approximately $\$ 8.00$ to $\$ 10.00 / \mathrm{sq} \mathrm{m}(\$ 9.50$ to $\$ 12.00 / \mathrm{sq}$ yd). This cost does not include the cost of transport of equipment and materials to the site. 
DISCUSSION AND RECOMMENDATION (Previous use and this study):

ANTISKID has been used on several North American Treaty Organization (NATO) airfields throughout Europe. The applications have apparently provided successful long-lasting surfacings. These products are available in the United States through the current German manufacturer. The ANTISKID system is unusual in that it provides a fuel-resistant and highly antiskid surfacing. Most applications requiring fuel resistance are trafficked at slow speeds such as parking and maintenance areas. High-speed applications such as runways and some taxiways do not normally require protection from fuel spillage. The manufacturer states that they produce a product (PETROGRIP) designed for lowspeed applications with lower skid resistance and greater fuel resistance.

A previous North American licensee of a West German Company manufactured a product known as Promak. The Promak product produced by this manufacturer has not experienced the same success with their product.

\section{SUMMARY:}

The ANTISKID system can provide an effective fuel-resistant surface for runways and other airfield applications. The results of the skid testing for this study and other data show that the system provides excellent skid resistance. The maximum aggregate particle size of $3.5 \mathrm{~mm}(0.14 \mathrm{in}$.) indicates that the potential Foreign Object Damage (FOD) hazard would be considered remote, and the past successful airfield use also suggests that there is a minimum potential for FOD.

Airfield HMA pavements which have been in place for several years often experience surface raveling as a result of the aging of the pavements binder. These pavements would benefit from a seal coat material that could seal and bind together the surface. 


\section{Appendix B Fuel-Resistance Test Method}

This test is intended to provide a measurement of the fuel-resistance capabilities of a coal-tar-based rejuvenator. This test may be conducted in the laboratory or in the field after the rejuvenator has been applied to a hat-mix asphalt (HMA) pavement. The test procedure consists of the following steps, with adaptations required for laboratory testing given in italics.

a. Apparatus:

(1) 150-mm (6-in.)-diameter by 75-mm (3-in.)-high steel pipe; 100-mm (4-in.)-diameter pipe (Note 1: PVC pipe may be substituted for the steel pipe).

(2) Lid for the pipe.

(3) Metal ruler.

b. Materials:

(1) 100 percent silicon rubber sealant or other fuel-resistant sealant.

(2) Sufficient quantity of 87 octane (average) automotive gasoline. (Note: care should be exercised when dealing with a flammable substance like gasoline.)

c. Procedure:

(1) Locate a clean, representative surface on the rejuvenated pavement. Obtain a 150-mm (6-in.) core from a representative surface of the pavement.

(2) Outline the pipe on pavement surface and apply a bead of the silicon along this circumference. Place the pipe on this silicon bead, applying enough pressure to seat the pipe and remove any voids between them. 
(3) Allow the silicon sealant to cure for about $2.5 \mathrm{hr}$. (A longer cure time (24 hr) maybe required if the sealant fails during the test.)

(4) Pour about $25 \mathrm{~mm}$ ( 1 in.) of gasoline into the pipe, measuring distance to the top of the pipe with the ruler. Cover the pipe with the lid.

(5) Measure how much gasoline goes through the pavement and visually observe the pavement surface and gasoline within the pipe every 15 min.

(6) Repeat this measurement and observations for a total of $30 \mathrm{~min}$ or until all the gasoline passes through the pavement. If any gasoline seeps through the silicon sealant pipe or pavement interface, the test is invalid and should be repeated at a new location or on a new core.

(7) After $30 \mathrm{~min}$, remove any remaining gasoline or break the seal and let it flow away. Immediately inspect the tested surface and note if the surface is easily damaged or particles dislodged through light scraping with a metal spatula or other suitable metal object. Also note any discoloration of the gasoline at the end of the 30-min test period.

\section{d. Failure Criteria:}

(1) If more than $5 \mathrm{~mm}(0.2 \mathrm{in}.) \pm 1.25 \mathrm{~mm}(0.05 \mathrm{in}$.) of gasoline penetrates the rejuvenated pavement surface after $30 \mathrm{~min}$, the fuel resistance is not acceptable.

(2) If the material of the tested pavement surface is easily dislodged (discolored or darkened gasoline is evidence of this), the fuel resistance is not acceptable. 


\section{Appendix C Recommended Guide Specification}




\section{UNITIED STATES AIR FORCE GUIDE SPECIFICATION}

SECTION TABLE OF CONTENTS

BITUMINOUS REJUVENATION

\section{$04 / 02$}

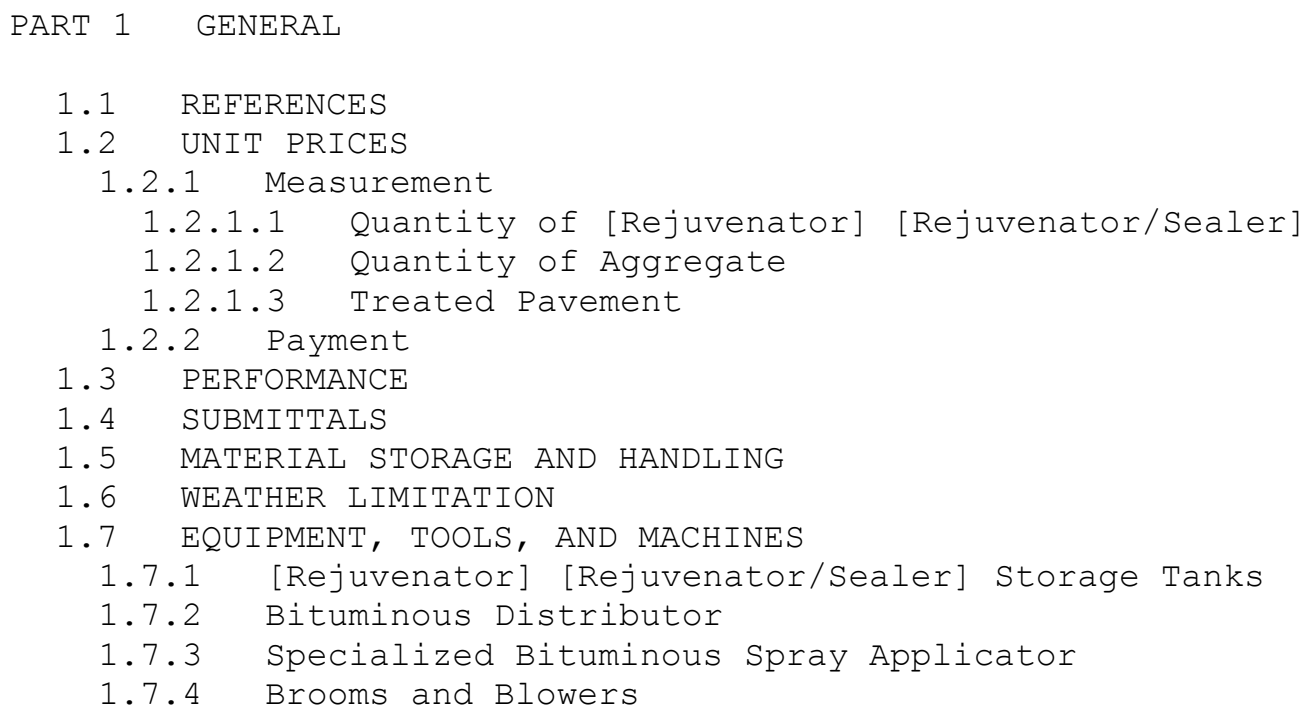




\section{UNITIED STATES AIR FORCE GUIDE SPECIFICATION}

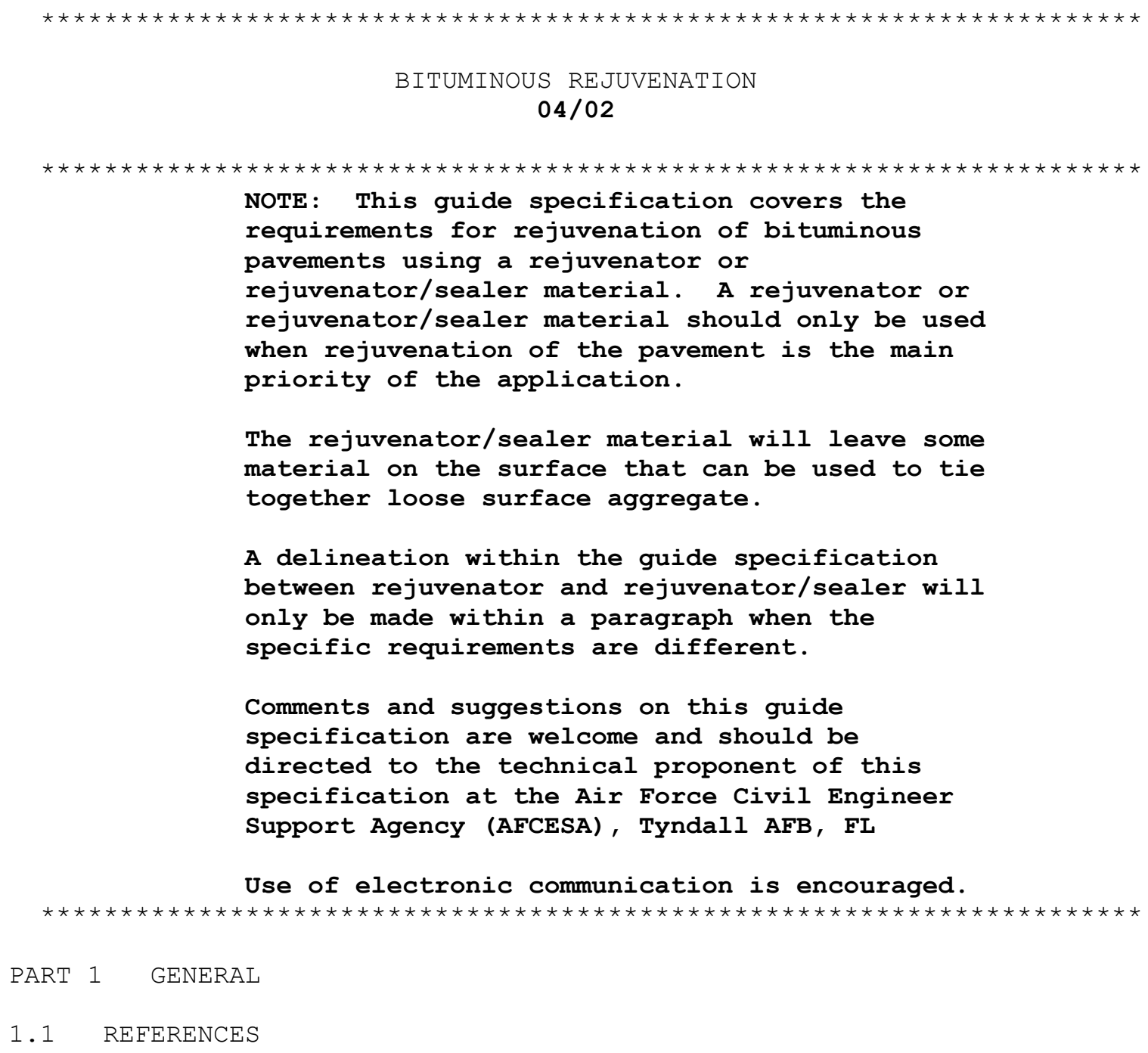


ASTM D 1856

ASTM D 2170

ASTM D 2171

ASTM D 2172

ASTM D 2995 (1995a) Recovery of Asphalt from Solution by Abson Method

(1995) Kinematic Viscosity of Asphalts (Bitumens)

(2001) Viscosity of Asphalts by Vacuum Capillary Viscometer

(1995) Quantitative Extraction of Bitumen from Bituminous Paving Mixtures

(1999) Determining Application Rate of Bituminous Distributors

\title{
1.2 UNIT PRICES
}

\begin{abstract}
NOTE: Delete these paragraphs when lump-sum bidding is used. Delete reference to aggregate, when the product manufacturer does not require it. Rejuvenator materials do not require aggregate. Rejuvenator/Sealers leave a portion of their material on the surface of the pavement and may be able to hold aggregate to provide satisfactory skid resistance until worn off.
\end{abstract}

\subsubsection{Quantity of [Rejuvenator] [Rejuvenator/Sealer]}

The quantity of [Rejuvenator] [Rejuvenator/Sealer] to be paid for will be the number of [liters] [gallons] used in the accepted work as determined by the contracting officer, corrected to [liters at 15 degrees C] [gallons at 60 degrees $\mathrm{F}$ ] in accordance with ASTM D 1250, and provided that the measured quantities are not 20 percent over the approved application rate. Any amount of [Rejuvenator] [Rejuvenator/Sealer] exceeding the approved application rate by more than 20 percent will be deducted from the measured quantities except for irregular areas where hand spraying of the rejuvenator is necessary. The contracting Officer will determine the actual application rate by dividing the number of [liters] [gallons] of [Rejuvenator] [Rejuvenator/Sealer] actually applied by the number of [square meters] [square yards] of pavement treated.

\subsubsection{Quantity of Aggregate}

The quantity of aggregate paid for will be the number of [metric tons (tons)] [cubic meters (cubic yard)] of aggregate placed and accepted in the completed work or placed in authorized stockpiles.

\subsubsection{Treated Pavement}

The quantity of pavement treated with [Rejuvenator] [Rejuvenator/ Sealer] will be paid according to the number of [square meters] 
[square yards] completed and accepted as determined by the contracting officer. The number of [square meters] [square yards] of treated pavement will be determined by measuring the length and width of the specified work area. Measurements to determine the number of [square meters] [square yards] will be along the surface of the pavement and will be to the closest [25 millimeter] [inch] for width and the closest [meter] [foot] for length.

\subsubsection{Payment}

Quantities of [Rejuvenator] [Rejuvenator/Sealer] [, aggregate, ] and treated pavement will be paid for at respective unit prices. Payment will not be made for quantities of [Rejuvenator] [Rejuvenator/Sealer] and treated pavement when actual application rate of rejuvenator is more than 20 percent below the approved application rate until deficiency is corrected in accordance with paragraph Insufficient Rejuvenator Material.

NOTE: The reduction in viscosity achieved will be dependent upon several factors, especially the amount of rejuvenator applied to the surface. Reductions of 40 percent can be specified; however, in areas where skid resistance is critical (high-speed locations), lower than normal application rates may need to be applied, with resulting lowering of rejuvenation of the pavement. Rejuvenator/ sealers that use a sand application during placement do not normally require a reduction in application rate, provided the aggregate produces satisfactory skid resistance.

\subsection{PERFORMANCE}

The [Rejuvenator] [Rejuvenator/Sealer] shall be applied so that the test properties of binder extracted from samples of the upper [9 mm] [3/8 inch] of the surface of the test section show that viscosities have decreased by at least \{\} percent. The percent decrease in viscosity shall be computed as follows:

100 ((Viscosity of untreated sample) - (Viscosity of treated sample))/(Viscosity of untreated samples)

\subsection{SUBMITTALS}

NOTE: Submittals must be limited to those necessary for adequate quality control. The importance of an item in the project should be one of the primary factors in determining if a submittal for the item should be required.

Indicate submittal classification in the blank space following the name of the item requiring the submittal by using " $G$ " when the submittal 


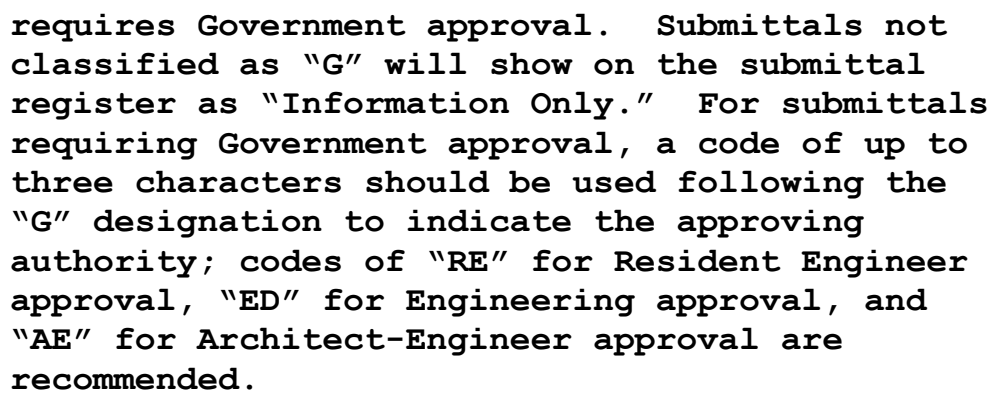

Government approval is required for submittals with a "G" designation; submittals not having a " $G$ " designation are for information only. When used, a designation following the "G" designation identifies the office that will review the submittal for the Government. The following shall be submitted in accordance with Section 01330 SUBMITTAL PROCEDURES:

\section{SD-03 Product Data}

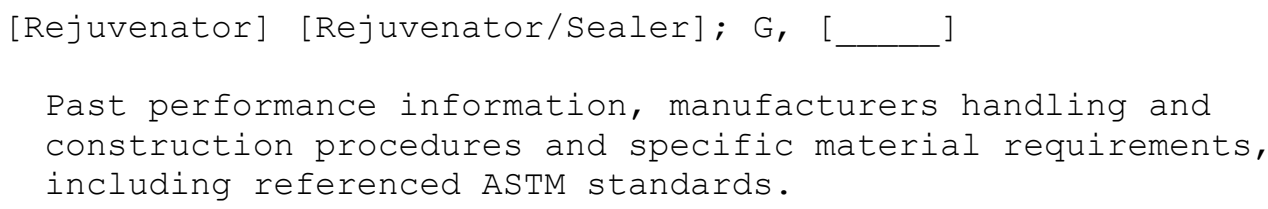

[Rejuvenator] [Rejuvenator/Sealer] shall be stored within temperature ranges recommended by the manufacturer. Due to concerns with flammability, smoking, fire, or flames other than heaters that are part of the equipment will not be permitted in the vicinity of heating, distributing, or material transferring operations.

\subsection{WEATHER LIMITATION}

The [Rejuvenator] [Rejuvenator/Sealer] shall be applied to a dry surface when the atmospheric temperature in the shade is [10 degrees C] [50 degrees F] or above. Application shall be delayed if rain appears imminent within 8 hours following planned time of application.

\subsection{EQUIPMENT, TOOLS, AND MACHINES}

Equipment, tools, and machines shall be subject to approval and shall be maintained in satisfactory working condition at all times. 


\subsection{1 [Rejuvenator] [Rejuvenator/Sealer] Storage Tanks}

[Rejuvenator] [Rejuvenator/Sealer] storage tanks shall be capable of heating the rejuvenating material under effective and positive control at all times to the required temperature. Heating shall be accomplished by steam coils, hot oil, electricity, or another suitable method. An armored thermometer shall be affixed to the tank so that the temperature of the material may be read at all times.

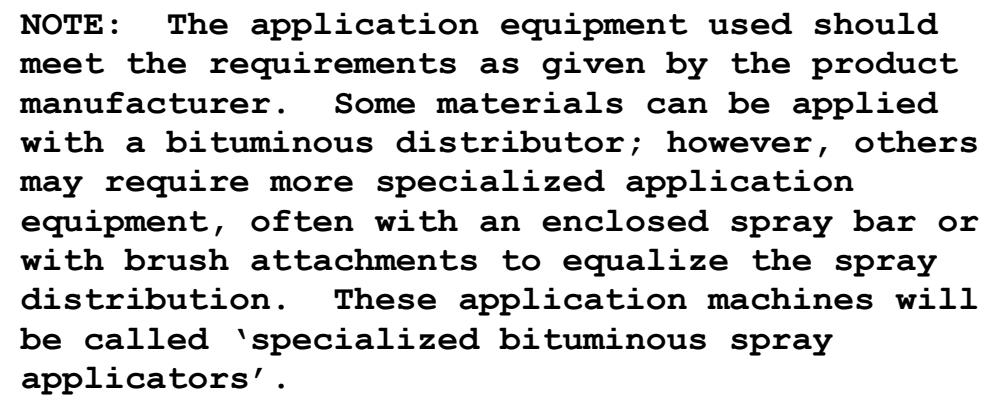

\subsubsection{Bituminous Distributor}

The bituminous distributor shall be designed and equipped to spray the bituminous material in a uniform double or triple lap at the temperature recommended by the manufacturer, at variable widths, and at readily determined and controlled rates from [0.10 to 1.0 liter per square meter] [0.04 to 0.2 gallon per square yard] with an allowable variation from the specified rate of not more than plus or minus 5 percent. Distributor equipment shall include a separate power unit for the bitumen pump, full-circulation spray bars, tachometer, pressure gauges, volume-measuring devices, adequate heaters for heating of materials to the proper application temperature, a thermometer for reading the temperature of tank contents, and a hand hose attachment suitable for applying bituminous material manually to areas inaccessible to the distributor. The distributor shall be equipped to circulate and agitate the bituminous material during the heating process.

\subsubsection{Specialized Bituminous Spray Applicator}

The specialized bituminous spray applicator shall be designed and equipped to apply rejuvenator/sealer material as recommended by the manufacturer. The application rate shall be readily determined and controlled from [0.10 to 0.5 liter per square meter] [0.04 to 0.1 gallon per square yard] with an allowable variation from the specified rate of not more than plus or minus 5 percent. These machines shall meet all other equipment requirements given in paragraph: Bituminous Distributor.

\subsubsection{Brooms and Blowers}

Brooms and blowers shall be of the power type and shall be suitable for cleaning the surfaces of bituminous pavements. 


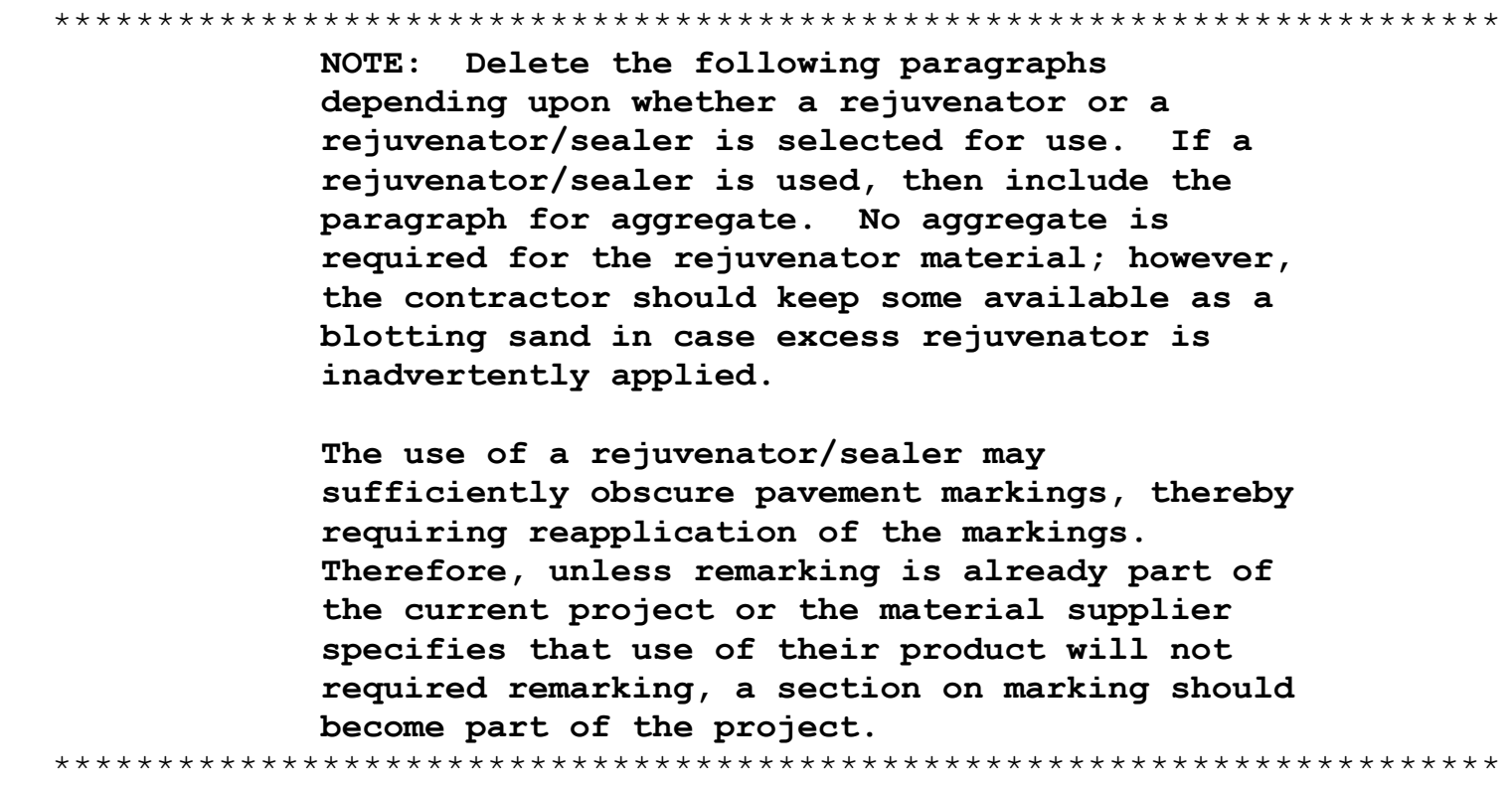

\subsection{REJUVENATOR}

The rejuvenator material shall have a proven record of satisfactory performance based on the ability of the material to decrease the viscosity of the binder material. The material selected shall neither permanently damage nor obscure pavement markings. Specific application specifications shall be as recommended by the manufacturer and approved by the contracting officer. The rejuvenating material shall be sampled according to ASTM D 140 and the test results shall conform to the material requirements as given by the material manufacturer.

\subsection{REJUVENATOR/SEALER}

The rejuvenator/sealer material shall have a proven record of satisfactory performance based on the ability of the material to decrease the viscosity of the binder material. The material shall also have a proven record of leaving enough residual material on the pavement surface to prevent the loss of surface aggregate and to hold the application of aggregate for increased skid resistance. The rejuvenating material shall be sampled according to ASTM D 140 and the test results shall conform to the material requirements as given by the material manufacturer.

\subsection{AGGREGATE}

The aggregate shall be applied to the surface of the treated pavement immediately following application of the rejuvenator/sealer material. The aggregate shall consist of clean, sound, durable particles of crushed stone, slag, or gravel. The aggregate shall meet the gradation requirements as given below: 


\begin{tabular}{ccc} 
Sieve Designation & & Percent by Weight Passing \\
\cline { 2 - 3 } $1.18 \mathrm{~mm}$ & & 100 \\
$0.60 \mathrm{~mm}$ & $25-100$ \\
$0.30 \mathrm{~mm}$ & $2-25$ \\
$0.15 \mathrm{~mm}$ & $0-5$ \\
Sieve Designation & Percent by Weight Passing \\
\hline No. 16 & 100 \\
No. 30 & $25-100$ \\
No. 50 & $2-25$ \\
No. 100 & $0-5$
\end{tabular}

PART 3 EXECUTION

\subsection{PREPARATION OF SURFACE}

Immediately before applying the [rejuvenator] [rejuvenator/sealer], loose material, dirt, clay, or other objectionable material shall be removed from the surface to be treated. After the cleaning operation and prior to application of the rejuvenator, the contracting officer will inspect the area to be treated to determine fitness of the area to receive the [rejuvenator] [rejuvenator/sealer].

\subsection{APPLICATION OF [REJUVENATOR] [REJUVENATOR/SEALER] MATERIAL}

Following preparation and subsequent inspection of the surface, the [rejuvenator] [rejuvenator/sealer] shall be uniformly applied over the surface to be treated at the approved rate with an allowable variation from the approved rate of application of plus or minus 10 percent. Materials shall be applied at the temperature recommended by the supplier. To obtain uniform application of the material on the surface treated at the junction of previous and subsequent applications, building paper shall be spread on the surface at a sufficient distance back from the ends of each application so that the material may be started and stopped on the paper. Immediately after application, the building paper shall be removed and properly disposed. Areas missed by the distributor shall be properly treated with the hand spray. Following application of the [rejuvenator] [rejuvenator/sealer], the surface shall not be disturbed for a period of at least 24 hours.

\subsubsection{Calibration Test}

Contractor shall furnish all equipment, materials, and labor necessary to calibrate the bituminous distributor or other application equipment. Calibration shall be made with approved job material and prior to applying the [rejuvenator] [rejuvenator/sealer] to the prepared surface. Calibration of the bituminous distributor and the specialized bituminous spray applicator shall be in accordance with ASTM D 2995. 


\subsubsection{Excess [Rejuvenator] [Rejuvenator/Sealer] Material}

Approved mineral aggregate shall be provided by the contractor and shall be spread in sufficient quantity to effectively blot up any excess [rejuvenator] [rejuvenator/sealer] material remaining on the treated pavement surface after 24 hours.

3.2.3 Ponding and Puddling of [Rejuvenator] [Rejuvenator/Sealer] Material

If low spots and depressions in the pavement surface cause ponding or puddling of the [rejuvenator] [rejuvenator/sealer], the pavement surface shall be broomed with a broom drag. Brooming shall continue until the pavement surface is free of any pools of excess material.

\subsubsection{Excess Runoff of [Rejuvenator] [Rejuvenator/Sealer]}

The application rate shall be reduced if the surface grade of the pavement surface, causes excessive runoff of the [rejuvenator] [rejuvenator/sealer]. Additional [rejuvenator] [rejuvenator/sealer] may be applied after the first application of material has penetrated into the pavement.

\subsubsection{Insufficient Rejuvenator Material}

When it is determined by the contracting officer that the actual application rate of the [rejuvenator][rejuvenator/sealer] is more than 20 percent below the approved application rate, subsequent applications of materials shall be made to bring the actual application rate up to the approved rate; additional [rejuvenator] [rejuvenator/sealer] material shall penetrate into the pavement surface within 24 hours after application.

\subsection{SAMPLING AND TESTING}

\subsubsection{Test Section}

Prior to application of the [rejuvenator] [rejuvenator/sealer] material, a representative test section shall be prepared on the pavement to be treated. If it is anticipated that the amount of material applied will have to be varied to meet existing different pavement surface conditions, then the test section should be broken up to include a representative section of each surface condition. The test sections shall be treated with various amounts of material, up to a maximum amount that the pavement can absorb. The application rate shall not exceed that which the pavement can absorb within 24 hours. Testing shall be conducted on samples obtained from the top [9 mm] [3/8 inch] of each of these treated areas to measure the viscosity and thus determine the desired application rate. The samples of treated material shall be obtained no sooner than 24 hours after application of [rejuvenator] [rejuvenator/ sealer]. An application rate shall be selected by the contractor to obtain the specified reduction in asphalt viscosity and to ensure that all the material penetrates into the pavement surface within 24 hours. Application of the [rejuvenator] [rejuvenator/sealer] shall not begin until the test sections have been evaluated and the 
required application rate has been approved by the contracting Officer.

\subsubsection{Sampling}

Sampling of the test section shall be performed before and after the pavement has been rejuvenated. In order for enough asphalt cement to be recovered, a minimum of three $150 \mathrm{~mm}$ (6-in.) cores will be required. Comparative cores taken before and after treatment should be taken close to the same locations, at a minimum within the same paving lane and within $0.5 \mathrm{~m}$ ( $1 \mathrm{ft}$ ) of each other. Samples taken from the treated test section areas shall be taken no sooner than 24 hours after application of the [rejuvenator] [rejuvenator/sealer].

\subsubsection{Testing}

An independent testing laboratory approved by the Contracting Officer shall conduct testing. Tests shall be conducted to extract the bituminous binder according to ASTM D 2172 and recover according to ASTM D 1856. Viscosity of the bituminous material shall be measured in accordance with ASTM D 2170 or ASTM D 2171 as applicable. The change in viscosity shall be determined for each application rate of [rejuvenator] [rejuvenator/sealer] in the test section from tests conducted on samples taken before and samples taken after the pavement surface has been rejuvenated.

-- End of Section -- 


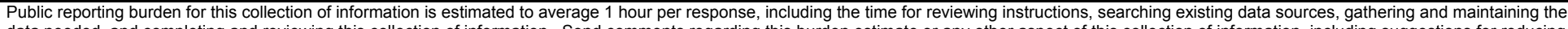

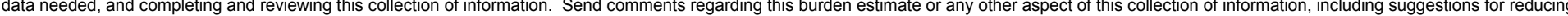

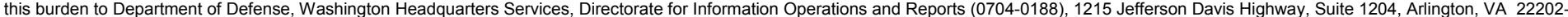

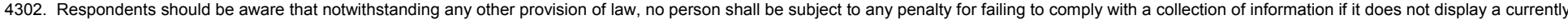
valid OMB control number. PLEASE DO NOT RETURN YOUR FORM TO THE ABOVE ADDRESS.

\begin{tabular}{l|l|l} 
1. REPORT DATE (DD-MM-YYYY) & 2. REPORT TYPE & 3. DATES COVERED (FrOm - To)
\end{tabular}

February 2003

4. TITLE AND SUBTITLE

Final report

Rejuvenators, Rejuvenator/Sealers, and Seal Coats for Airfield Pavements

5a. CONTRACT NUMBER

5b. GRANT NUMBER

6. AUTHOR(S)

5c. PROGRAM ELEMENT NUMBER

James E. Shoenberger

5d. PROJECT NUMBER

5e. TASK NUMBER

5f. WORK UNIT NUMBER

7. PERFORMING ORGANIZATION NAME(S) AND ADDRESS(ES) AND ADDRESS(ES)

8. PERFORMING ORGANIZATION REPORT NUMBER

U.S. Army Engineer Research and Development Center

Geotechnical and Structures Laboratory

ERDC/GSL TR-03-1

3909 Halls Ferry Road

Vicksburg, MS 39180-6199

9. SPONSORING / MONITORING AGENCY NAME(S) AND ADDRESS(ES)

10. SPONSOR/MONITOR'S ACRONYM(S)

U.S. Air Force Civil Engineering Support Agency

Tyndall Air Force Base, Florida 32403-6011

11. SPONSOR/MONITOR'S REPORT NUMBER(S)

\section{DISTRIBUTION / AVAILABILITY STATEMENT}

Approved for public release, distribution is unlimited.

\section{SUPPLEMENTARY NOTES}

\section{ABSTRACT}

There are a number of proprietary rejuvenator, rejuvenator/sealer, and a seal coat materials currently available. It should be noted that throughout this report the term rejuvenator will be used to describe both rejuvenator and rejuvenator/sealer materials, because the primary purpose in this study was to use these materials to rejuvenate the asphalt pavement. Because of the proprietary nature of these materials, specifications that use performance-based requirements rather than material requirement specifications are highly preferred. One important requirement in the development of this type of specification is a field performance comparison of the various materials with known application and material property parameters.

The objective of this study was to investigate the comparative field performance of various rejuvenators and seal coat materials. The field performance of these materials was evaluated over a period of more than 1 year. The materials evaluated in this study were proprietary products. The study was not intended to determine the best or optimum rejuvenator or seal coat material but was intended to provide information for the development or updating of guide specifications for the use of these types of materials.

The scope of this study was to evaluate several types of coal-tar- and petroleum-based rejuvenators and seal coat materials. The materials were placed at two airfields and their effect on the binder properties of the treated pavement was compared to untreated areas. The field performance of the rejuvenator and seal coat materials was evaluated through their effects on skid resistance, texture, and changes on visual appearance. This report covers the placement and performance of the materials included in this study.

(Continued)

\section{SUBJECT TERMS}

Asphalt rejuvenation

Bituminous pavement rejuvenation

Pavement rejuvenator

16. SECURITY CLASSIFICATION OF:

\begin{tabular}{|l|l|l|}
\hline a. REPORT & b. ABSTRACT & c. THIS PAGE \\
UNCLASSIFIED & UNCLASSIFIED & UNCLASSIFIED \\
\hline
\end{tabular}

17. LIMITATION OF ABSTRACT

Pavement sealers Seal coats

Rejuvenator

Rejuvenator/Sealers

\begin{tabular}{l|l}
\multicolumn{1}{|l|}{$\begin{array}{l}\text { 17. LIMITATION } \\
\text { OF ABSTRACT }\end{array}$} \\
UNCLASSIFIED &
\end{tabular}

\begin{tabular}{|c|l|}
$\begin{array}{l}\text { 18. NUMBER } \\
\text { OF PAGES }\end{array}$ & 19a. NAME OF RESPONSIBLE PERSON \\
\cline { 2 - 2 } 119 & $\begin{array}{l}\text { 19b. TELEPHONE NUMBER (include area } \\
\text { code) }\end{array}$ \\
\hline
\end{tabular}

Standard Form 298 (Rev. 8-98)

Prescribed by ANSI Std. 239.18 


\section{ABSTRACT (Concluded).}

To better evaluate the performance of both the rejuvenators and seal coat materials, the field sections should be periodically evaluated over the next several years. The guide specification for bituminous rejuvenation (Appendix C) should be used and evaluated in the U.S. Air Force project.

Additional investigation is required for further development of a test method for determining the effectiveness of a rejuvenator. This would involve the development of an effective means of aging both coal-tar- and asphalt-based rejuvenated asphalt cements. The rejuvenator and rejuvenator/sealer products that leave residual material on the pavement surface would require investigation to determine how much and what component of the product enters into the pavement to provide rejuvenation. 